\title{
The Oxymoron of Caged Animal Welfare: A Case Study in The Australian Caged Rabbit Meat Industry
}

\author{
Reem Lascelles \\ PhD Medical Physics, University of Hertfordshire, United Kingdom \\ ORCID: 0000-0002-5201-6114
}

Received: February 2019

Accepted: March 2019

Recommended citation. LASCELLES, R., The Oxymoron of Caged Animal Welfare: A Case Study in The Australian Caged Rabbit Meat Industry, dA. Derecho Animal (Forum of Animal Law Studies) 10/2 (2019)DOI https://doi.org/10.5565/rev/da.419

\begin{abstract}
The objective of this research is to investigate how the current animal welfare regulatory approach in Australia is applied to domesticated rabbits with emphasis on rabbits used for meat. Australia's animal welfare regime is critically examined by assessing the effectiveness of the Model Code of Practice for Animal Welfare: Intensive Husbandry of Rabbits (MCOPIHR) and the Five Freedoms in practice and what they mean to the actual wellbeing of rabbits in meat farms. Recent scientific knowledge in animal behaviour informs us that keeping any animal in extreme confinement, such as rabbits used for meat in intensive farms, has serious welfare concerns resulting in physical and psychological suffering. It is within this context that this thesis asks whether the concept of animal welfare in the caged rabbit meat industry is in effect an oxymoron. This thesis draws on work by Bekoff and Pierce's ethological approach to support my critique of animal welfare practices in Australia's rabbit meat industry. I also use Garner's theory of incremental change in animal welfare reform, in which he argues for using current knowledge in animal welfare to push the boundaries of what is considered 'unnecessary suffering', as a social driver for a moral shift aimed at effecting law reform. To complement Garner's political theory of incremental change I deploy Spira's approach to advocacy, as practical tools for realising change.
\end{abstract}

Keywords: Animal Welfare; Rabbit Meat Industry; Model Code of Practice; Five Freedoms; Ethology; Domesticated Rabbits; Inconsistencies in Law..

Resumen - El oxímoron del bienestar animal enjaulado: un estudio de caso en la industria australiana de la carne de conejo enjaulado

El objetivo de este estudio es investigar cómo se aplica el enfoque actual de regulación del bienestar animal en Australia a los conejos domesticados con énfasis en los conejos utilizados para la carne. Se examina de forma crítica el régimen de bienestar animal de Australia al evaluar la efectividad del Código modelo de práctica para el bienestar animal: Intensive Husbandry of Rabbits (MCOPIHR) (cría intensiva de conejos) y las Cinco Libertades (Five Freedoms) en la práctica y lo que significan para el bienestar real de los conejos en las granjas de carne. Los conocimientos científicos recientes sobre el comportamiento de los animales nos informan que mantener a cualquier animal en confinamiento extremo, como en el que se encuentran los conejos utilizados para carne en granjas intensivas, conlleva serios problemas de bienestar que resultan en sufrimiento físico y psicológico. Es en este contexto que esta tesis cuestiona si el concepto de bienestar animal en la industria de la carne de conejo enjaulado es en realidad un oxímoron. Esta tesis se basa en el trabajo del enfoque etológico de Bekoff y Pierce para apoyar mi crítica de las prácticas de bienestar animal en la industria de carne de conejo de Australia. También utilizo la teoría de Garner sobre el cambio incremental en la reforma del bienestar animal, en la que defiende el uso del conocimiento actual sobre bienestar animal para ampliar 
los límites de lo que se considera "sufrimiento innecesario", como un impulsor social para un cambio moral dirigido a llevar a cabo una reforma jurídica. Para complementar la teoría política de Garner sobre el cambio incremental, implemento el enfoque de Spira para la defensa, como herramientas prácticas para realizar el cambio.

Palabras clave: Bienestar animal; industria de la carne de conejo; Código modelo de práctica; Cinco Libertades; etología; conejos domesticados; incoherencias de la ley.

\section{List of Contents}

1. Introduction \& Methodology

2. Animals and the Law in Australia

3. Analysis of the Regulatory Framework of the Domestic Rabbit in Australia

4. Analysis of Welfare in the Australian Domestic Rabbit Meat Industry

5. Discussion - Down the Rabbit Hole of Morality - A Need for Reform

6. Conclusions, Recommendations and Future Research Directions

Bibliography

Appendices

\section{List of Abbreviations}

\begin{tabular}{|l|l|}
\hline Term & Abbreviation \\
\hline AAC & Australian Agricultural Council \\
\hline AAWS & Australian Animal Welfare Strategy \\
\hline AEC & Animal Ethics Committee \\
\hline AHA & Animal Health Australia \\
\hline APB & Agriculture Protection Board \\
\hline ANZFRMC & Australia New Zealand Food Regulation Ministerial Council \\
\hline ARRPA & Agriculture and Related Resources Protection Act \\
\hline AWSC & Animal Welfare Science Centre \\
\hline BoR & Brief of Requirements [of Rabbits] \\
\hline COAG & Council of Australian Governments \\
\hline Cth & Commonwealth \\
\hline EFSA & European Food and Safety Authority \\
\hline MCOP & Model Codes of Practice \\
\hline MCOPIHR & Model Code of Practice for the Welfare of Animals: Intensive Husbandry of Rabbits \\
\hline NHMRC & National Health and Medical Research Council \\
\hline NSW & New South Wales \\
\hline OIE & World Organisation for Animal Health \\
\hline PIMC & Primary Industry Ministerial Council \\
\hline RCD & Rabbit Calicivirus Disease \\
\hline RIRDC & Rural Industries Research and Development Corporation \\
\hline RHD & Rabbit Haemorrhagic Disease \\
\hline RSPCA & The Royal Society for the Prevention of Cruelty to Animals \\
\hline Vic & Victoria \\
\hline WA & Western Australia \\
\hline
\end{tabular}


'Welfarism is a cage that traps human perception, one that also confines our sense of empathy for other beings. We need to open the doors to the cage'.

Marc Bekoff \& Jessica Pierce ${ }^{1}$

\section{Chapter 1. Introduction \& Methodology}

\section{Introduction and Background to Research}

There has been considerable research into Australian animal welfare legislation and inconsistencies whereby animals of the same species are subject to different standards of welfare protection depending on the context of their use, and independent of their own interests. ${ }^{2}$ However, little or no work has been done on Australian animal welfare laws pertaining to domestic rabbits in different contexts of use: research, food, fur, entertainment, exhibition, and as companions. Therefore, the main objective of this thesis is to investigate how the current animal welfare regime in Australia protects domestic rabbits with an emphasis on rabbits used for food. Following from that objective, this thesis also aims to highlight specific areas of needed reform.

For the purpose of this thesis, domesticated rabbits are those who are farmed in cages for industries such as food and research, and those used in the pet industry. Wild rabbits are those who are eradicated, shot, trapped and hunted for meat known as game. ${ }^{3}$ Price defines animal domestication as the '[p]rocess by which captive animals adapt to man and the environment he provides'. ${ }^{4}$ Domestication is '[a]chieved by a combination of genetic changes occurring over generations, and environmental stimulation and experiences during an animal's lifetime'. ${ }^{5}$ Domestication of the rabbit is relatively recent ${ }^{6}$ and although domestic varieties of rabbits have been artificially selected through years of cross-breeding and selection by rabbit enthusiasts ${ }^{7}$ and scientists, ${ }^{8}$ the domestic rabbits' behavioural repertoire is still the same as in the wild rabbit, i.e. no behaviour patterns have been lost, and no new ones created. ${ }^{9}$

Wild rabbits are out of the scope of this investigation, although some historical reference to them is made in Chapter Three when describing the evolution of legislation surrounding rabbits in Australia.

For the purpose of this thesis the analysis of the regulatory framework of domestic rabbits is confined to those industries in which rabbits are most commonly used and caged or bred within cages. Caging animals in conditions of extreme confinement such as rabbits used for meat in intensive farms carries with it serious welfare concerns as animals are unable to express natural behaviour and are known to experience physical and psychological suffering. ${ }^{10}$

Although the standard regulatory approach for animal welfare in Australia is centred on a positive duty of care ${ }^{11}$ and the prohibition against cruelty, ${ }^{12}$ the current animal welfare framework does not prohibit the use of cages or confinement in its scope. The concept of animal welfare instead embraces all sorts of species in cages. ${ }^{13}$ It is within the context of cages that this thesis analyses how animal welfare is applied to domestic

1 BEKOFF, M.- PIERCE, J., The Animals' Agenda: Freedom, Compassion and coexistence in the Human Age (Beacon Press, 2017) 175.

2See for example McEWAN, A.B., The Concept of Violence: A Proposed Framework for the Study of Animal Protection Law and Policy (PhD Thesis, The Australian National University, 2016); WHITE, S., Regulation of Animal Welfare in Australia and the Emergent Commonwealth: Entrenching the Traditional Approach of the States and Territories or Laying the Ground for Reform? (2007) 35 Federal Law Review 347.; O’SUllivAN, S., Animals, Equality and Democracy (Palgrave MacMillan, 2011); CAULFIELD, M., Handbook of Australian Animal Cruelty Law (Animals Australia, 2009).

3 Centre for Invasive Species Solution, Rabbit Legislation in Australia $<$ https://www.pestsmart.org.au/pestsmart-factsheet-rabbitlegislation-in-australia/>.

4 PRICE, E., Behavioral development in animals undergoing domestication (1999) 65 Applied Animal Behaviour Science 246.

5 Ibid.

6 Domestication of rabbits began in the 16th century. MONNEROT et al., Rabbit and man: genetic and historic approach (1994) 26 (1) Genet Sel Evol 178.

7 See for example the Australian National Rabbit Council.

8 FOSTER, M., Australian Farmed Rabbit Prospects for Industry Development (1999) RIRDC Publication No 99/89.

9 Scientific Panel on Animal Health and Welfare, 'The Impact of the current housing and husbandry systems on the health and welfare of farmed domestic rabbits' (2005) 267 The EFSA Journal 16.

10 BEKOFF, M.- PIERCE, J., The Animals' Agenda: Freedom, Compassion and coexistence in the Human Age (Beacon Press, 2017) 37.

11 For example, Animal Welfare Act 1993 (Tas), s6 Duty of Care 'A person who has the care or charge of an animal has a duty to take all reasonable measures to ensure the welfare of the animal'.

12 WHITE, S., Regulation of Animal Welfare in Australia and the Emergent Commonwealth: Entrenching the Traditional Approach of the States and Territories or Laying the Ground for Reform? (2007) 35 Federal Law Review 347.

13 Examples are sows, pregnant pigs, who typically grow to over $300 \mathrm{~kg}$, living out most of their lives in individual gestation metal crates measuring 60 centimeters in width by 2.2 meters in length unable to turn around [Model Code of Practice of the Welfare of 
rabbits.

There are two main investigations developed in this thesis:

Firstly, I examine how domestic rabbits under different contexts of human use are regulated and protected by the current animal welfare regime. This establishes knowledge in current animal welfare laws applied to the domestic rabbits in line with Garner's theory of incremental change in reform. Garner's theory is based on using current knowledge in animal welfare as a social driver to achieve moral shifts and attitudes to drive social and legislative change. ${ }^{14}$

Several studies on animal welfare in Australia have identified a range of inconsistencies in Australian animal welfare standards and practice applied to animals of the same species under different uses. ${ }^{15}$ The result is that some animals are more vulnerable to cruel treatment depending on the settings in which they are kept. ${ }^{16}$ For example, McEwan highlights the welfare inconsistencies between the standards applying to greyhounds bred for the racing industry under the Racing Act 2002 (Qld) compared to dogs raised as companion animals. ${ }^{17}$ White argues that the current animal welfare regulatory approach has inconsistencies in the approach to the treatment of different categories of animals. ${ }^{18}$ Further, in her book Animals, Equality and Democracy, O'Sullivan argues that the visibility of animals within society is proportional to the degree of their protection by animal welfare laws. ${ }^{19}$ Within this context of inconsistencies within animal welfare legislation, the analysis of the regulatory framework for domestic rabbits in different settings of human use will be assessed to establish whether inconsistencies exist within the domestic rabbit industries.

Secondly, I expand on the findings of the regulatory assessment on domestic rabbits with a more focused analysis of the regulatory regime for domestic rabbits in the intensive rabbit meat industry. In addition, within the context of caged rabbit welfare, I examine the husbandry code of practice for the welfare of rabbits in intensive rabbit farms, the Model Code of Practice for the Welfare of Animals: Intensive Husbandry of Rabbits ${ }^{20}$ against empirical data ${ }^{21}$ to determine and assess what is common practice within the caged rabbit meat industry and investigate if animal welfare can be achieved in practice.

The empirical data and current animal welfare practices within the caged rabbit meat industry are assessed against the 'Five Freedoms'. The Five Freedoms underpin Australian animal welfare, as defined by the Australian Royal Society for the Prevention of Cruelty to Animals (RSPCA) ${ }^{22}$ and Animal Health Australia, ${ }^{23}$ two national animal welfare bodies in Australia. I examine whether each of the Five Freedoms is achievable in practice.

My method of analysis draws on work by Bekoff and Pierce's ethological approach, ${ }^{24}$ to develop a critique of animal welfare practice in Australia's rabbit meat industry. Based on the evidence analysed, I develop a framework for rabbit wellbeing. I draw on the 'Science of Animal Wellbeing' 25 as developed by Bekoff and Pierce to provide an ethical framework that bridges what I show is a gap between animal welfare

Animals: Pigs, Appendix 3]. Rabbits raised for meat raised on an area of $0.07 \mathrm{~m} 2$ translating to an area approximately the size of an A4 sheet of paper [Model Code of Practice for the Welfare of Animals: Intensive Husbandry of Rabbits]. Layer hens can be confined in cages at a density of $550 \mathrm{~cm} 2$ of floor space per bird which is less than an A4 sheet of paper [Model Code of Practice for the Welfare of Animals: Domestic Poultry, Appendix 1].

14 GARNER, R., Political Ideology and the legal status of animals (2002) Animal Law 8, 80.

15 See for example McEWAN, A. B., The Concept of Violence: A Proposed Framework for the Study of Animal Protection Law and Policy (PhD Thesis, The Australian National University, 2016); WHITE, S., Regulation of Animal Welfare in Australia and the Emergent Commonwealth: Entrenching the Traditional Approach of the States and Territories or Laying the Ground for Reform? (2007) 35 Federal Law Review 347.; O’SUllivan, S., Animals, Equality and Democracy (Palgrave MacMillan, 2011); CAULFIELD, M., Handbook of Australian Animal Cruelty Law (Animals Australia, 2009); GOODFELLOW, J., Animal welfare regulation in the Australian agricultural sector: a legitimacy maximising analysis (PhD thesis, Macquarie University, 2015); NEUMANN, G., and Associates Pty Ltd, Review of the Australian Model Codes of Practice for the Welfare of Animals: Final Report (9 February 2005).

16 O'SULliVAN, S., Animals, Equality and Democracy (Palgrave MacMillan, 2011) 166.

17 McEWAN, A.- SKANDAKUMAR, K., The Welfare of Greyhounds in Australian Racing: Has the Industry Run its Course? (2011) 5 Australian Animal Protection Law Journal 53, 20.

18 WHITE, S., Regulation of Animal Welfare in Australia and the Emergent Commonwealth: Entrenching the Traditional Approach of the States and Territories or Laying the Ground for Reform? (2007) 35 Federal Law Review 347.

19 O'SULliVAN, S., Animals, Equality and Democracy (Palgrave MacMillan, 2011) 4.

20 CSIRO Publishing and Primary Industry Standing Committee (Cth), Model Code of Practice for the Welfare of Animals: Intensive Husbandry of Rabbits (Primary Industries Report Series 33, 2003), 4.

21 2016, was the first-time that the conditions of rabbits reared in intensive meat farms appeared publicly on television. Some of the welfare concerns highlighted by the footage included injured and deceased rabbits; lack of areas to for rabbits to hide as prey animals; minimal cage space seeing rabbits compacted into a small space unable to move, along with poor welfare standards in hygiene. Channel Seven, 'The disturbing reality behind caged rabbits bred for their meat', 7News, 18 September 2016 (Bryan Seymour) $<$ https://au.news.yahoo.com/the-disturbing-reality-behind-caged-rabbits-bred-for-their-meat-32652779.html\#page1>. 22 RSPCA, Five freedoms for animals (12 Jun 2009) <http://kb.rspca.org.au/five-freedoms-for-animals_318.html >.

23 Animal Health Australia, About Us (19 July 2018) <https://www.animalhealthaustralia.com.au/who-we-are/company-profile/>. 24 BEKOFF, M.- PIERCE, J., The Animals’ Agenda: Freedom, Compassion and coexistence in the Human Age (Beacon Press, 2017). 25 Ibid.

110 Derecho Animal. Forum of Animal Law Studies, vol. 10/2 
and ethics. I also combine Robert Garner's perspective on incremental animal welfare reform, in which he argues to establish and use knowledge in current animal welfare, such as those applied to domestic rabbits, as a driver for a moral shift. These shifts lay the foundation for legislation change ${ }^{26}$ which can be aimed at banning rabbit meat farms. Lastly, I draw on Henry Spira's advocacy work in the areas of law reform and corporate campaigning. ${ }^{27}$

\subsection{Why the rabbit?}

Western society's conflicted attitude towards rabbits as companions and commodities is reflected in this 1943 excerpt by Life Magazine:

'Domestic rabbits are one of the few pets that can be enjoyed dead or alive. Stewed or fried, they have the flavor of white chicken meat. As pets, they are friendly and decorative'. ${ }^{28}$

Despite the growing popularity of the domestic rabbit as a companion animal in Australia, ${ }^{29}$ rabbit welfare in the different contexts of human use is an issue that has to date attracted little attention. This lack of attention is probably the result of an ingrained cultural view of the rabbit and their common status as a 'pest' in Australia. ${ }^{30}$

The adoption of the domestic rabbit as a case study has been inspired by the absence of any systematic examination $^{31}$ of the conditions or common practices within rabbit meat farms in Australia by animal advocacy groups. Research by Voiceless, the Animal Protection Institute, has been conducted on a variety of farmed animals, mainly dairy cows, pigs and chickens. ${ }^{32}$ This information provides valuable resources for animal advocates. However, there remains a gap in knowledge about the rabbit meat industries and other forms of rabbit use. This thesis will support the animal advocacy movement by presenting new work on the rabbit meat industry.

The process of categorisation of animals can diminish perceptions of their capacity to suffer, leading to reduced human moral concern towards them. ${ }^{33}$ Categories under which rabbits fall such as 'pest' or 'food' animals can deeply influence human behaviour and emotion depending on their interests towards the animals, inspiring an ethical stance by them. ${ }^{34}$ Subsequently, human interests towards certain types of species drive animal welfare laws such as 'necessary suffering' if a substantial benefit to humans is likely to occur such as in the industries of food and research. ${ }^{35}$ As the category under which species fall is determined by culture, ${ }^{36}$ paradoxes will be inevitable for animals such as the rabbit, where the rabbit's moral standing has an extra layer of complexity in Australia seeing their long history of being perceived as a 'pest' which will be summarised in Chapter Three.

\subsection{Research Questions}

The main research question posed in this thesis is whether the concept of animal welfare in the caged rabbit meat industry is an oxymoron. The Cambridge dictionary defines 'oxymoron' as two words used together that have, or seem to have, opposite meanings. ${ }^{37}$ In this thesis I use the word oxymoron to highlight the relationship between cages and animal welfare.

With this question in mind, my research investigates the following issues:

26 GARNER, R., 'Political Ideology and the legal status of animals' (2002) Animal Law 8, 80.

27 SINGER, P., Ethics into Action: Henry Spira and the Animal Rights Movement (Rowaman \& Littlefield, 1998).

28 DEMELLO, M.- DAVIS, S.E., Stories Rabbits Tell (Lantern Books, 2003) 227.

29 According to an Australian survey conducted by Animal Medicines Australia in 2016, the rabbit is the fifth most popular companion in Australia. Animal Medicines Australia, Pet Ownership in Australia 2016 (2016)< http://animalmedicinesaustralia.org.au/wpcontent/uploads/2016/11/AMA Pet-Ownership-in-Australia-2016-Report sml.pdf $>, 10$.

30 Centre for Invasive Species Solution, 'Rabbit Legislation in Australia' $<$ https://www.pestsmart.org.au/pestsmart-factsheet-rabbitlegislation-in-australia/>.

31 Inconsistencies in legislation within NSW for the different uses of domestic rabbits have been investigated by Siohban O'Sullivan. O’SULLIVAN, S., Animals, Equality and Democracy (Palgrave MacMillan, 2011).

32 Voiceless, Reports and Briefings $<$ https://www.voiceless.org.au/content/reports-briefings $>$.

33 LOUGHNAN, S. et al, The role of meat consumption in the denial of moral status and mind to meat animals (2010) Appetite 55,156-159; BASTIAN, B., et al., Don't Mind Meat? The Denial of Mind to Animals Used for Human Consumption (2012) Pers Soc Psychol Bull 38, 247-256.

34 HERZOG, H., The Moral Status of Mice (1988), American Psychologist 'Comments',473.

35 GARNER, R., Animals, Ethics and Public Policy (2010), The Political Quarterly, 81(1),126.

36 TAYLOR, N.- SIGNAL, T., Pet, Pest, Profit: isolating differences in attitudes towards the treatment of animals (2009) Anthrozoos, $22,134$.

$37<$ https://dictionary.cambridge.org/dictionary/english/oxymoron>. 
- How are the domestic rabbit industries regulated under different contexts of use?

- What animal welfare regime applies to rabbits in intensive meat farms during farming and slaughter?

- How effective is the current husbandry Model Code of Practice for the Welfare of Animals: Intensive

Husbandry of Rabbits in protecting the welfare of the caged rabbit used for food?

- How effective are the Five Freedoms in ensuring the wellbeing of rabbits in the caged rabbit meat industry?

- Ultimately is the concept of Animal Welfare in the caged rabbit meat industry an oxymoron?

These questions provide a framework to introduce the analysis put forward to support my arguments that rabbit meat farms ought to be banned and that we need to shift thinking away from domestic rabbit welfare, towards 'rabbit wellbeing'.

\subsection{Theoretical framework}

My research is influenced by the work of several scholars working in related fields. Firstly, Marc Bekoff, an ecologist and biologist and Jessica Pierce, a bioethicist who have developed the theory of the 'Science of Animal Wellbeing' expanding the Five Freedoms into an ethical framework. ${ }^{38}$

The 'Science of Animal Wellbeing' as proposed by Bekoff and Pierce assesses animals according to their own needs, in addition to an ethical component, which is 'to be free from human exploitation' ${ }^{39}$ Bekoff and Pierce highlight the need to understand the ethology ${ }^{40}$ of species as a first step of advocacy for animals. ${ }^{41}$ They argue that we must first understand a species' actual needs for wellbeing as opposed to current animal welfare science which evaluates the wellbeing of animals assuming the human methods of exploiting the animals are morally sound and justifiable. ${ }^{42}$ I therefore use an ethological study of rabbits ${ }^{43}$ to assess what the application of animal welfare science on rabbits within the caged meat industry means to their actual wellbeing.

Robert Garner, a political theorist specialising in animal rights, proposes an incremental approach to relieve animal suffering by focusing on ways we should use current knowledge in animal welfare as a social driver for a moral shift to change legislation. ${ }^{44}$ As the Australian animal welfare laws pertaining to domestic rabbits is an area which has not been analysed or explored, I use Garner's approach to expand the knowledge of current animal welfare laws and to highlight specific areas of needed reform. This is contained in the analysis in Chapters Three and Four. Garner also argues that the welfare notion of 'unnecessary suffering' is not static and animal advocates can continue to question and expand on what is regarded as 'unnecessary'. ${ }^{45}$ On this basis, I use the analysis of current practice of animal welfare as applied to rabbits in meat farms to highlight what is morally 'unnecessary suffering' which could be addressed by reform.

Henry Spira's civil rights and animal rights ${ }^{46}$ advocacy complements Garner's incremental approach. Spira's success in achieving incremental change ${ }^{47}$ in animal welfare reform is a tool that I believe could be used for legislative or corporate campaigning to ban rabbit meat farms. I use some of Spira's ten key points for successful campaigning, ${ }^{48}$ including understanding where people's thinking is at present with rabbits, and where it can go tomorrow, as fundamental to implementing change in the moral attribution of the rabbit.

\subsection{Methodology}

This research takes the form of a case study. According to Harrison, a case study approach is a versatile

\footnotetext{
38 BEKOFF, M.- PIERCE, J., The Animals' Agenda: Freedom, Compassion and coexistence in the Human Age (Beacon Press, 2017). 39 Ibid 175.

40 Collins English dictionary defines ethology as 'the study of the behaviour of animals in their normal environment' < https://www.collinsdictionary.com/dictionary/english/ethology>.

41 BEKOFF, M.- PIERCE, J., The Animals' Agenda: Freedom, Compassion and coexistence in the Human Age (Beacon Press, 2017) 29.

42 Ibid 24.

43 CORNELISSEN, J.M.R., et al, Report 524: Brief of Requirements of the Rabbit (2011) Wageningen UR Livestock Research. 44 GARNER, R., Political Ideology and the legal status of animals (2002) Animal Law 8, 80.

45 GARNER, R., The Politics of Animal Rights (2008) British Politics 3, 118.

46 SINGER; P., Ethics into Action: Henry Spira and the Animal Rights Movement (Rowaman \& Littlefield, 1998).

47 Examples of Henry Spira's successful campaigns include pressurising the cosmetics industry to phase out its use of the Draize test; the end of face branding of cattle. SINGER; P., Ethics into Action: Henry Spira and the Animal Rights Movement (Rowaman \& Littlefield, 1998).
}

48 SPIRA, H., Fighting to win, in Peter Singer (ed), In Defense of Animals (Blackwell, 1985) 194-208.

112 Derecho Animal. Forum of Animal Law Studies, vol. 10/2 
form of qualitative inquiry ${ }^{49}$ 'with a purpose to gain an understanding of the issue in real life settings and is recommended to answer 'how' and 'why' or less frequently 'what' research questions'.

The elements in this thesis which make up a case study approach are: ${ }^{51}$

1. A Case Study Design: this is a single case exploratory study based on the domestic rabbit. The design has four components; the objective; the questions; the theoretical framework; and the methodology used to answer the questions.

2. A bounded system: this thesis is bound in jurisdiction, regulatory context and timeframe.

3. Studied in context: the context in this thesis is with regards to the different uses of rabbits and the real-life setting in industrialised rabbit meat farms in Australia.

4. Multiple sources of evidence: photographic evidence is sourced from different animal rights organisations, with data spanning over a number of years and from different jurisdictions.

5. In-depth study: chosen for intensive regulatory analysis of the animal welfare legislation pertaining to the domestic rabbit.

In conducting this research, Google Scholar was used as the basic search engine to conduct the literature review. The Legal Database Information System JADE was used to scope existing and repealed Australian legislation pertaining to the rabbit. ${ }^{52}$ Database keyword searches were [Rabbit, Pest, Noxious animal, Rabbit Meat Farms, Rabbit Meat, Animal Cruelty, Animal Welfare]. Current legislation was sourced from the legislation websites in New South Wales, ${ }^{53}$ Victoria ${ }^{54}$ and Western Australia. ${ }^{55}$ Model Codes of Practice were sourced from the Commonwealth Scientific and Industrial Research Organisation (CSIRO) ${ }^{56}$ Some guidelines and standards and some industry codes were available on different State primary industry websites.

\subsection{Positionality Statement}

According to Harrison, a case study approach lends itself to being subjective and interpreted according to the researcher's own positionality. ${ }^{57}$ It is through this assertion that I declare my position in relation to this research.

I have used the term "oxymoron" in my title to draw the attention to the idea that the use of cages under the rubric of animal welfare is rife with contradiction. Applying animal welfare concepts in arenas where animals are caged, and causing tremendous animal suffering, is 'oxymoronic' because it is obvious that putting animals in a cage deprives them of their natural needs and behaviours. ${ }^{58}$

I have a history of activity in rabbit rescue, rehabilitation and in running an Animal Sanctuary. I have observed physically and psychologically damaged ex meat rabbits who were beyond rehabilitation. Their lack of response and 'brokenness' reflect animal welfare standards motivated by economic needs rather than any real regard for their wellbeing. These many instances of rehabilitating damaged sentient beings have led me to question the effectiveness and motivations of the current animal welfare regime.

My role as a rabbit rescuer and rehabilitator gives me good grounding and insights borne of long-term observation as to what constitutes rabbit wellbeing and normal behaviours. This knowledge has been accumulated over 15 years as a rescuer.

I believe that in-order to help alleviate domestic rabbit suffering there is a need to question current practices in animal welfare. Further, to achieve this goal, a shift in society's attitudes towards rabbits will be needed. Therefore, broadly, this work is as an act of advocacy. However, I take a rigorous approach supported by academic literature in a variety of scholarship, including Spira.

\subsection{Chapter Overview and Terminology}

49 HARRISON, H.- BIRKS, M.- FRANKLIN, R.- MILLS, J., Case Study Research: Foundations and Methodological Orientations (2017) 18(1) Qualitative Social Research Forum 8.

50 Ibid 12.

51 Ibid 13.

52 JADE (Judgments and Decisions Enhanced) What is JADE? $<$ https://jade.io/t/home $>$.

53 New South Wales Government, NSW Legislation $<$ https://www.legislation.nsw.gov.au $>$

54 Victorian Legislation and Parliamentary Documents, Victorian Law Today Library $<$ http://www.legislation.vic.gov.au>.

55 Government of Western Australia, Western Australian Legislation <https://www.legislation.wa.gov.au>.

56 CSIRO Publishing, Food \& Agriculture:Livestock Codes $<$ http://www.publish.csiro.au>.

57 HARRISON, H.- BIRKS, M.- FRANKLIN, R.- MILLS, J., Case Study Research: Foundations and Methodological Orientations (2017) 18(1) Qualitative Social Research Forum 6.

58 SINGER, P.- MASON, J., The ethics of what we eat (Text Publishing Co, 2006) 19-39, 41-48. 


\subsubsection{A Note on Terminology}

The following terminology will be applied throughout this thesis:

Firstly, for simplicity, non-human animals will be referred to as 'animals'; an 'introduced' species will be referred to as a 'non-native' species. The use of the term 'pest' only appears as part of legislative statutes or references to literature; a domestic animal with a non-economic value will be referred to as a 'companion' animal rather than a 'pet'. The term 'pet' is only used as part of the definition of the 'pet industry' or with reference to literature, and lastly animals, including rabbits will be given a subjective gender-neutral pronoun such as 'they', and will not be referred to as 'it'. This also applies to the application of the pronouns 'who' and 'whom'.

\subsubsection{Chapter Overview}

Chapter One states the main objective of the thesis, which is to investigate how the current animal welfare regulatory approach protects rabbits used for food. The thesis is based on a case study approach and uses the work of Bekoff, Pierce, Garner and Spira as an integrated model for a theoretical and practical advocacy framework of proposed reform.

Chapter Two introduces Australia's governance structure and explains the current animal welfare regime in Australia. Included in the chapter is the general layout of animal welfare legislation as a foundation to my analysis in Chapters Three and Four. I introduce the Model Codes of Practice for the Welfare of Animals (MCOP) underpinning animal welfare legislation for intensively farmed animals such as the rabbit, including the codes' adoption conditions under the law. I give an overview of the animal welfare science approach in Australia which is based on fitness and biological functioning rather than behaviour. I also introduce the animal welfare concept of the Five Freedoms which underpins the definition of animal welfare under the Royal Society for the Prevention of Cruelty to Animals (RSPCA).

Chapter Three is divided into two parts. Part one is a history of the rabbit in Australia and how this has shaped the current Australian attitudes towards rabbits. Key changes in legislation from 1880 to the present day are discussed, beginning with the declaration of rabbits in Australia as a 'pest' to agriculture, to permitting their use under caged or enclosed conditions for personal and commercial purposes. This sets the scene to understand present societal thinking and where it may go in the future. Understanding this is fundamental to implementing change in the moral attribution of the rabbit in accordance with Spira's ten key points of advocacy. ${ }^{59}$ Spira's ten point system is his recommendations for working in animal advocacy, based on his experiences, and aimed at helping future advocates end animal suffering. ${ }^{60}$ Part two analyses how domestic rabbits under different contexts of use are regulated in the economic settings of food, research and pet industries and the non-economic setting as companion animals within the jurisdictions of New South Wales, Victoria and Western Australia. The relationship between the regulatory statutes governing the rabbit's different uses (food, research and pet) and state and territory animal welfare legislation is highlighted. The discussion establishes the regulatory concepts.

To highlight inconsistencies in the application of animal welfare protection for rabbits, the husbandry standards applied to rabbits in meat farms under the Model Code of Practice for the Welfare of Animals: Intensive Husbandry of Rabbits ${ }^{61}$ (MCOPIHR) are compared to the husbandry practices of rabbits used in research in the Guidelines for the Housing of Rabbits in Scientific Institutions. ${ }^{62}$ The comparison highlights how two industries, using caged rabbits, differ in their animal welfare standards and practice.

Chapter Four discusses the two animal welfare regimes highlighted in Chapter Three, which protect rabbits raised and killed for food. Those two regimes cover the husbandry and welfare of domestic rabbits on the farm as set out by the Model Code of Practice for Animal Welfare: Intensive Husbandry of Rabbits (MCOPIHR) and the animal welfare standards applied to rabbits during slaughter.

To evaluate Australia's animal welfare regulatory approach as applied to domestic rabbits used for food, the MCOPIHR is compared against the Five Freedoms. Having compared these two animal welfare standards, I review empirical data in the form of video footage and photographic data from rabbit meat farms in Western Australia (WA) and Victoria (Vic) of what, I argue, represent conditions in which a significant number of rabbits are kept in Australian rabbit meat farms.

59 SPIRA, H., Fighting to win, in Peter Singer (ed), In Defense of Animals ( Blackwell, 1985)194-208.

60 Ibid.

61 CSIRO Publishing and Primary Industry Standing Committee (Cth), Model Code of Practice for the Welfare of Animals: Intensive Husbandry of Rabbits (Primary Industries Report Series 33, 2003).

62 Department of Agriculture (NSW) ARRP Guideline 18: Guidelines for the Housing of Rabbits in Scientific Institutions, 2003 (State of New South Wales, 2003).

114 Derecho Animal. Forum of Animal Law Studies, vol. 10/2 
The animal welfare issues raised by the analysis of current husbandry practices, and the MCOPIHR in this chapter, are compared against international scientific studies of rabbit husbandry systems. These international studies provide a reference point as to whether, biologically and behaviourally, adequate standards of rabbit welfare are being met in Australia in practice.

Chapter Five summarises the short falls in animal welfare as applied to domestic rabbits and what effect they have on rabbit wellbeing. The discussion ascertains that animal welfare is unable to protect rabbits within cages and identifies why large-scale rabbit meat farms in Australia cannot exist without the use of confinement such as cages. Following this, a reform into a new animal wellbeing framework is proposed. Bekoff and Pierce's 'Science of wellbeing' ${ }^{63}$ is discussed as a proposed ethical framework shifting from welfarism to a more compassionate moral framework.

In line with Spira's advocacy strategies, the success of any animal protection reform, such as phasing out the cage, will depend on understanding where people's thinking of rabbits is and how it can change, which supports law reform strategies. On this basis, Chapter Five highlights what effect labelling rabbits has on their moral standing and emotional attribution by presenting scholarly findings within the sphere of social and psychological research which examine the effect of what the different categorisations of rabbits, such as 'pet', 'pest' and 'profit animals' mean to their welfare in Australia.

Finally, areas of reform are recommended. These involve a change from the current animal welfare paradigm towards an 'animal wellbeing', drawing on up to date knowledge of rabbit ethological studies as proposed by Bekoff and Pierce to drive policy changes. ${ }^{64}$ The proposed reform expands on the flexible animal welfare notion of 'unnecessary suffering' in its moral sense, to drive public opinion and move towards banning rabbit meat farms, based on Garner's incremental approach. ${ }^{65}$ In addition, I draw on Spira's practical advocacy work ${ }^{66}$ a tool for advocacy and campaigning with this aim.

Chapter Six summarises the findings of the thesis based on the thesis question. It provides recommendations and ideas for future research directions to support animal protection and advocacy for rabbits.

\section{Chapter 2. Animals and the Law in Australia}

This chapter creates the framework for the case study by presenting an overview of Australia's governance structure, including how law is introduced and the nomenclature of legal documents. It also includes a summary of Australia's animal protection regime.

As the Model Code of Practice for the Welfare of Animals: Intensive Husbandry of Rabbits ${ }^{67}$ (MCOPIHR) is central to the thesis analysis, the emphasis is on Model Codes of Practice for the Welfare of Animals (MCOP) and their legal status. This provides a background for the analysis of rabbit welfare regulation in New South Wales (NSW), Victoria (Vic) and Western Australia (WA) undertaken in Chapters Three and Four.

\subsection{Legislative Framework in Australia}

Australia is a constitutional monarchy, ${ }^{68}$ governed as a representative democracy. ${ }^{69}$ Members of Parliament, known as the legislature (i.e. the Senate ${ }^{70}$ and the House of Representatives ${ }^{71}$ ) are elected democratically to represent the interests of the Australian people.

Australia inherited a common law legal system ${ }^{72}$ in 1788 when it was colonised by the British. ${ }^{73}$ In

63 BEKOFF, M.- PIERCE, J., The Animals' Agenda: Freedom, Compassion and coexistence in the Human Age (Beacon Press, 2017). 64 Ibid.

65 GARNER, R., Political Ideology and the legal status of animals (2002) Animal Law 8, 80.

66 SPIRA, H., Fighting to win, in Peter Singer (ed), In Defense of Animals ( Blackwell, 1985)194-208.

67 CSIRO Publishing and Primary Industry Standing Committee (Cth), Model Code of Practice for the Welfare of Animals: Intensive Husbandry of Rabbits (Primary Industries Report Series 33, 2003).

68 The Constitutional monarchy is the system where the Queen or King are the heads of state but must act within the constitution. The Governor-General is the monarch's representative. The current head of State is Elizabeth II, and Governor General is Peter Cosgrove. 69 Parliamentary Education Office, Legal Fact Sheets <https://www.peo.gov.au/learning/fact-sheets.html $>$.

70 The Senate is also known as the upper house. It is made up of 76 senators. Each senator represents one of Australia's six states or two territories. Parliamentary Education Office, Legal Fact Sheets <https:/www.peo.gov.au/learning/fact-sheets.html $>$.

71 The House of Representatives is also known as the lower house or the people's house. There are 150 members elected to the House of Representatives. They are referred to as Ministers of Parliament (MP). Each MP represents one of the 150 federal electorates in Australia. Parliamentary Education Office, Legal Fact Sheets <https://www.peo.gov.au/learning/fact-sheets.html $>$.

72 ELLIS, E., Principles and Practice of Australian Law (Thomson Reuters Australia, Edition 3, 2013 ) 133.

73 English law became the legal foundation of all Australian colonies because they were treated as "settled colonies" which had no perceived existing laws as they were considered "Terra Nullius". ELLIS, E., Principles and Practice of Australian Law (Thomson 
1828, the British Parliament passed legislation ${ }^{74}$ which meant that all states became recipient of both the Statute and common laws as settled colonies ${ }^{75}$ according to the needs of the Australian colony. ${ }^{76}$

On the $1^{\text {st }}$ of January $1901,{ }^{77}$ the Commonwealth Constitution came into force. It created a 'federal' system of government whereby powers were divided between a central federal (commonwealth) government and state governments. ${ }^{78}$ The Australian Constitution establishes the rules by which Australia is governed. Law-making responsibilities are divided between the Federal and State and Territory Parliaments. ${ }^{79}$ Under section 122 of the Australian Constitution, the Federal Government also has power to make laws for Australia's Territories. ${ }^{80}$ The states retained legislative power through their individual state constitutions ${ }^{81}$ over all other matters that are not controlled by the Commonwealth under Section 51 of the Australian Constitution. ${ }^{82}$ Local councils work within the boundaries of legislation enacted by state parliaments. ${ }^{83}$

The Australian Constitution sets out three separate constitutional powers and functions; ${ }^{84}$ the Legislature (the House of Representatives and the Senate) ${ }^{85}$ the Executive (the government) ${ }^{86}$ and the Judiciary (the courts). ${ }^{87}$ In addition, each state has its own legislature, executive, and judiciary. ${ }^{88}$ (See Appendix 1).

\section{The Legislative Process}

In Australia, commonwealth laws, which bind all Australians, are enacted by the federal Parliament. In addition, state and territory parliaments make laws for their respective jurisdictions. Lastly, laws made by local government (councils and shires) are called 'by-laws' ${ }^{89}$

When a newly drafted law is introduced into Parliament it is called a Bill. ${ }^{90}$ Both houses of Parliament must debate the Bill and approve of its enactment. Once this is achieved, the Governor General gives the Bill assent, as representative of the reigning monarch. ${ }^{91}$ Once assented, a Bill becomes an Act of Parliament and the law is called statute law $^{92}$ (See Appendix 1).

Reuters Australia, Edition 3, 2013) 24.

74 Australian Courts Act 18289 Geo IV c83, Section 24. ELLIS, E., Principles and Practice of Australian Law (Thomson Reuters Australia, Edition 3, 2013) 25.

75 ELLIS, E., Principles and Practice of Australian Law (Thomson Reuters Australia, Edition 3, 2013$) 25$.

76 Colonization was based on the doctrine of terra nullius which was overturned in Mabo (No 2). It is important to acknowledge that 'settlement' as the premise on which the Australian legal system was established is contested. As the court found in Mabo (No 2), and as we are all aware, Australia was not terra nullius, a land belonging to no-one, in 1788. It was in possession of its Indigenous population, which had its own system of law, or lore, that was handed down from the elders through spoken word, ritual, and cultural practice. Central Queensland University, Equity Week One study Guide page 8.

77 The Australian Constitution was passed as an Act of the British Parliament the Commonwealth of Australia Constitution Act 1900 (UK) and took effect on 1 January 1901. The Public Interest Advocacy Centre, Australian legal system $<$ http://legalanswers.sl.nsw.gov.au/hot-topics-79-australian-legal-system>.

78 Australian Government, Federation <https://www.australia.gov.au/about-government/how-government-works/federation>.

79 With regards to animals and animal welfare, the Australian Constitution provides the Commonwealth Government with indirect powers over the regulation of animals in international trade, such as quarantine powers (s51(ix)); fisheries power (s 51(x)); trade and commerce power (s51(i)). The majority of law relating to animals and animal cruelty remain within the States and Territories legislation. BRUCE, A., Animal Law in Australia: An Integrated Approach (LexisNexis Butterworths, 2nd ed, 2017$) 75$.

80 Constitution Act (Cth) s122 'Government of territories'.

81 Constitution Act 1902 (NSW); Constitution Act 1975 (VIC); Constitution Act 1934 (TAS); Constitution of Queensland 2001 (QLD); Constitution Act 1889 (WA); Constitution Act 1934 (SA) .

82 Constitution Act (Cth) s107-108 provide States and Territories the power to legislate all matters not covered by the Commonwealth under section 51. For example; police, hospitals, education and public transport.

83 For example infrastructure, local roads and pet control.

84 The Australian Constitution Act.

85 The Australian Constitution defines the Legislative power in Chapter I. It consists of the Queen, a Senate, and a House of Representatives, and which is called The Parliament, or The Parliament of the Commonwealth.

86 The Australian Constitution defines the Executive Government in Chapter II. The executive power of the Commonwealth is vested in the Queen and is exercisable by the Governor-General as the Queen's representative.

87 The Australian Constitution defines the Judicial in Chapter III. The judicial power of the Commonwealth is vested in a Federal Supreme Court, called the High Court of Australia, and in other federal courts which the Parliament creates. The High Court consists of a Chief Justice, and other Justices, not less than two, as prescribed by the Parliament.

88 See for example the Constitution Act 1902 (NSW), Part 2 Powers of the Legislature; Part 4 the Executive; Part 9 the Judiciary.

89 The Public Interest Advocacy Centre, Australian legal system

$<$ http://www.utas.edu.au/_data/assets/pdf_file/0017/334232/aust_leg_syst_601.pdf > .

90 The title is the Bill's full title and sets out in very broad terms the purpose or scope of the Bill. For example of an introduced Bill is the Live Animal Export (Slaughter) Prohibition Bill 2012 (Cth). ELLIS, E., Principles and Practice of Australian Law (Thomson Reuters Australia, Edition 3, 2013) 96.

91 The Constitution Act s 58 'Royal assent to Bills'.

92 Parliament of Australia, Making laws

$<$ https://www.aph.gov.au/About_Parliament/House_of_Representatives/Powers_practice_and_procedure/00_-

_Infosheets/Infosheet_7___Making_Laws>.

116 Derecho Animal. Forum of Animal Law Studies, vol. 10/2 
Other than Acts and Bills, there is also 'delegated' or 'subordinate' legislation. ${ }^{93}$ These instruments can take different forms, such as Regulations,${ }^{94}$ Standards ${ }^{95}$ or Codes. Regulations sit underneath the governing Act. ${ }^{96}$ Codes of Practice and Standards provide practical guidelines for specific practices. ${ }^{97}$

\subsection{Animal Welfare Legislation in Australia}

Under Australian law, domesticated animals are classified as property. ${ }^{98}$ The property status of animals is reflected in case law ${ }^{99}$ and the Australian Consumer Law whereby 'animals' are included within the definition of goods. ${ }^{100}$ Wild animals, i.e. those that have not been tamed into domestication, are property of the Crown. ${ }^{101}$

Australia's anti-cruelty legislation is descended from England in the $19^{\text {th }}$ century. ${ }^{102}$ Early legislation established a broad prohibition on cruelty to animals. ${ }^{103}$ In the mid- $19^{\text {th }}$ century, Australian anti-cruelty legislation was refined to include exemptions ${ }^{104}$ for some practices such as hunting and the extermination of rabbits. ${ }^{105}$

At the time of the federation in 1901, the Australian Constitution did not address the issue of animal welfare, instead it provided the Commonwealth Government with indirect powers over the regulation of animals in international trade, ${ }^{106}$ such as quarantine powers,${ }^{107}$ fisheries power, ${ }^{108}$ trade and commerce power. ${ }^{109}$ Subsequently, legislative powers relating to animal welfare remain with the states and territories. ${ }^{110}$

Today, every Australian state and territory has anti-cruelty legislation that prohibits animal cruelty, in the form of an act or an omission (such as neglect). ${ }^{111}$ The phrase 'animal cruelty' is defined as acts or omissions that cause 'unnecessary', 'unreasonable' or 'unjustified' suffering. ${ }^{112}$ For example, the Prevention of Cruelty to Animals Act 1986 (Vic) defines cruelty as if a person 'does or omits to do an act with the result that unreasonable pain or suffering is caused, or is likely to be caused, to an animal'. ${ }^{113}$

In the 1970s and 1980s, the states and territories added exemptions for certain farming practices. ${ }^{114}$ For example, section 9 of the Prevention of Cruelty to Animals Act 1979 (NSW) requires that animals are to be exercised. ${ }^{115}$ However, section 9(1A) does not apply to animals if the animal is (a) a stock animal, ${ }^{116}$ or (b) an

93 Delegated legislation exists in relation to an Act. It contains administrative details necessary to ensure that the provisions of the act will operate successfully. See for example section 62 of the Animal Research Act 1985 (NSW).

94 For example, Animal Research Act 1985(NSW) s 62 (1) specifies that the Governor may make regulations.

95 Standards are statements setting out what should be achieved. They are a statement of a level of quality of conduct that is acceptable.

Only standards that are written down in legislation are compulsory and enforceable. MHCC Mental Health Rights Manual, The Legal Framework $<$ http://mhrm.mhcc.org.au/chapter-2/2a.aspx $>$.

96 Office of Parliamentary Counsel (SA), Understanding legislation

$<$ https://www.legislation.sa.gov.au/Web/Information/Understanding\%20legislation/UnderstandingLegislation.PDF>.

97 For example, Australian Standard for the Hygienic Production of Meat and Meat Products for Human Consumption, FRSC Technical Report No. 3, AS 4696: 2007

98 According to Halsbury's Laws of Australia 'Domestic animals, like other personal and moveable chattels, are the subject of absolute property'. LexisNexis, Halsbury's Laws of Australia, vol 1(2), 20 Animals, '1 Property in Animals' [20-50].

99 RILEY, S., Animal Law Case Book (UTS 1st ed) 9-11

$<$ https://www.uts.edu.au/sites/default/files/2015\%20Final\%20Version\%20ANIMAL\%20LAW\%20CASE\%20BOOK\%201.pdf>.

100 Competition and Consumer Law Act 2010 (Cth), s 4 'goods includes: (b) animals, including fish.'

101 For example the National Parks and Wildlife Act 1974 (NSW) s 142 'royalty must be paid to the Crown at the prescribed rate for species of prescribed fauna and skins, unless the skin or carcass has been tagged in accordance with the legislation'.

102 CAULFIELD, M., Handbook of Australian Animal Cruelty Law (Animals Australia, 2009) 4.

103 BRUCE, A., Animal Law in Australia: An Integrated Approach (LexisNexis Butterworths, 2nd ed, 2017) 75.

104 WHITE, S., Regulation of Animal Welfare in Australia and the Emergent Commonwealth: Entrenching the Traditional Approach of the States and Territories or Laying the Ground for Reform? (2007) 35 Federal Law Review 347, Part II.

105 For example the Rabbit Nuisance Act 1883 (NSW).

106 BRUCE, A., Animal Law in Australia: An Integrated Approach (LexisNexis Butterworths, 2nd ed, 2017) 76.

107 Constitution Act s51(ix).

108 Ibid s 51(x).

109 Ibid s51(i).

110 BRUCE, A., Animal Law in Australia: An Integrated Approach (LexisNexis Butterworths, 2nd ed, 2017) 76.

111 McEWEN, G., Animal Law: Principles and Frontiers (2011) < [http://bawp.org.au/wp-content/uploads/2013/07/eBookFINAL.pdf>.

112 CAULFIELD, M., Handbook of Australian Animal Cruelty Law (Animals Australia, 2009) 22.

113 Prevention of Cruelty to Animals Act 1986 (Vic) s 9(1)(c).

114 WHITE, S., Regulation of Animal Welfare in Australia and the Emergent Commonwealth: Entrenching the Traditional Approach of the States and Territories or Laying the Ground for Reform? (2007) 35 Federal Law Review 347.

115 Prevention of cruelty to Animals Act 1979 (NSW) s9.(1) A person in charge of an animal which is confined shall not fail to provide the animal with adequate exercise. (1A) Subsection (1) does not apply to a person in charge of an animal if the animal is: (a) a stock animal other than a horse, or (b) an animal of a species which is usually kept in captivity by means of a cage.

116 Prevention of cruelty to Animals Act 1979 (NSW) s4 definition of stock animals: "stock animal means an animal which belongs to the class of animals comprising cattle, horses, sheep, goats, deer, pigs, poultry and any other species of animal prescribed for the 
animal of a species which is usually kept in captivity by means of a cage. ${ }^{117}$ Similarly, in 1980, the Victorian government amended its anti-cruelty legislation ${ }^{118}$ the Prevention of Cruelty to Animals Act 1986 (Vic) to exclude farming practices such as the slaughter of animals from the Act. ${ }^{119}$

Most animals that are excluded from the direct protection of the animal welfare Acts, i.e. those of economic use to humans, ${ }^{120}$ are managed under the MCOP. ${ }^{121}$ The existing MCOP set minimum standards ${ }^{122}$ of care and welfare to animals. ${ }^{123}$ Model Codes of Practice for the Welfare of Animals are currently in transition to Standards and Guidelines. ${ }^{124}$ Standards are legal requirements incorporated or referenced into relevant legislation, while Guidelines are recommended practices aimed at complementing the Standards. ${ }^{125}$ Some Standards and Guidelines have commenced operation. ${ }^{126}$ The MCOP will be discussed in more detail in section 2.2.1.

With regards to the enforcement of animal welfare law in Australia, three agents of authority are appointed; the RSPCA, ${ }^{127}$ the Police ${ }^{128}$ and the Primary Industry Departmental Authority. ${ }^{129}$ In most Jurisdictions, enforcement of animal welfare laws is largely undertaken by the RSPCA. ${ }^{130}$

\subsubsection{Model Codes of Practice for the Welfare of Animals}

The principle aim of the Model Codes of Practice for the Welfare of Animals (MCOP) is to set the minimum accepted practice for husbandry of major species, as a basis for national consistency in Australian animal welfare standards. ${ }^{131}$ A review of the MCOP found that contemporary animal welfare science has not been considered as a basis within those codes of practice. ${ }^{132}$ The secondary purpose of the MCOP is to reassure the public that animal welfare is being managed and standards exist and provide a framework for regulating livestock industries. ${ }^{133}$

There are 18 Australian MCOP for the Welfare of Animals. ${ }^{134}$ These were developed under the supervision of the Primary Industry ${ }^{135}$ Ministerial Council (PIMC) ${ }^{136}$ under the Council of Australian

purposes of this definition."

117 Prevention of cruelty to Animals Act 1979 (NSW) s9(1A)(b).

118 WHITE, S., Regulation of Animal Welfare in Australia and the Emergent Commonwealth: Entrenching the Traditional Approach of the States and Territories or Laying the Ground for Reform? (2007) 35 Federal Law Review 347.

119 Section 6 of the Prevention of cruelty to Animals Act 1986 (Vic): 'Application of Act (1) This Act does not apply to- (a) the slaughter of animals in accordance with the Meat Industry Act 1993 or any Commonwealth Act; or (f) the slaughter of a farm animal on a farm if - (i) it is slaughtered for consumption on that farm; and (ii) it is slaughtered in a humane manner; and (iii) it is not slaughtered for sale; and (iv) it is not slaughtered for use in the preparation of food for sale; and (v) it is not removed from that farm' 120 For example, animals defined as livestock and animals used for research. BRUCE, A., Animal Law in Australia: An Integrated Approach (LexisNexis Butterworths, 2nd ed, 2017) 209.

121 The Department of Primary Industries currently list 18 Model Codes of Conduct. NSW Department of Primary Industries, National Model Codes of Practice for the Welfare of Livestock <https:/www.dpi.nsw.gov.au/animals-and-livestock/animalwelfare/general/national>.

122 For example, Rabbits raised for meat are raised on an area of $0.07 \mathrm{~m} 2$ translating to an area approximately the size of an A4 sheet of paper. CSIRO Publishing and Primary Industry Standing Committee (Cth), Model Code of Practice for the Welfare of Animals: Intensive Husbandry of Rabbits (Primary Industries Report Series 33, 2003).

123 BRUCE, A., Animal Law in Australia: An Integrated Approach (LexisNexis Butterworths, 2nd ed, 2017 ) 209.

124 CAULFIELD, M., Animals in Australia (Vivid Publishing, 2018) 88.

125 Ibid.

126 For example, the Australian Animal Welfare Standards and Guidelines for the Land Transport of Livestock, the Australian Animal Welfare Standards and Guidelines for sheep, the Australian Animal Welfare Standards and Guidelines for Cattle.

127 Prevention of cruelty to animals Act 1979 (NSW) s 34B 'Approved charitable organisations: (1) The Minister may, by order published in the Gazette, approve of a charitable organisation for the purposes of the exercise by its officers of law enforcement powers under this Act'; Prevention of cruelty to animals Act 1986 (VIC) s18(1)(b)(ii).

128 Ibid.

129 WHITE, S., Regulation of Animal Welfare in Australia and the Emergent Commonwealth: Entrenching the Traditional Approach of the States and Territories or Laying the Ground for Reform? (2007) 35 Federal Law Review 347.

130 Ibid.

131 NEUMANN, G., and Associates Pty Ltd, Review of the Australian Model Codes of Practice for the Welfare of Animals: Final Report (9 February 2005) 5.

132 Ibid ii.

133 Ibid 5.

134 Those are: Animals at Saleyards; Cattle; Domestic Poultry, Farmed Buffalo; Farming of Ostriches; Feral Livestock Animals; Husbandry of Captive-Bred Emus; Intensive Husbandry of Rabbits; Land Transport of Cattle; Land Transport of Horses; Land Transport of Pigs; Land Transport of Poultry; Livestock and Poultry at Slaughtering Establishments; Pigs; The Camel; The Farming of Deer; The Goat; The Sheep. NSW Department of Primary Industries, National Model Codes of Practice for the Welfare of Livestock $<$ https://www.dpi.nsw.gov.au/animals-and-livestock/animal-welfare/general/national $>$.

135 Examples of Primary Industries are agriculture, food, fibre, forestry, fisheries and aquaculture. Malcolm Caulfield, Handbook of Australian Animal Cruelty Law (Animals Australia, 2009) 54 note 6.

136 The PIMC is chaired by the Federal Minister of Agriculture, Fisheries and Forestry, who has no legislative status over state and territory animal welfare. CAULFIELD, M., Handbook of Australian Animal Cruelty Law (Animals Australia, 2009$) 54$. 
Governments (COAG) ${ }^{137}$ In addition to the MCOP, the National Health and Medical Research Council (NHMRC) has produced the Australian Code of Practice of the Care and Use of Animals for Scientific Purposes for the use of animals in scientific research, ${ }^{138}$ while the Australia New Zealand Food Regulation Ministerial Council (ANZFRMC) has approved a code of practice concerning animal slaughter, the Australian Standard for the Hygienic Production of Meat and Meat Products for Human Consumption, which includes a section on animal welfare. ${ }^{139}$

The MCOP outline key management practices such as:

- Basic welfare needs (including water and food);

- Intensive stocking systems;

- Handling, mustering and yarding;

- Management practices;

- Health;

- Feral stock control and

- Humane destruction. ${ }^{140}$

The legal status of the MCOP varies among the states or territories. ${ }^{141}$ Some codes are mandatory. This means that their provisions are binding. Breach of a mandatory Code is also a breach of an animal welfare law. Other Codes are adopted though they are not mandatory. However, they are used as guidelines for animal husbandry or management. Still other Codes are neither compulsory nor adopted, they have no legal status. ${ }^{142}$ In some jurisdictions compliance with a MCOP may provide an exemption to a charge of animal cruelty. Compliance with a Code may also be submitted as evidence against a charge of animal cruelty. ${ }^{143}$

In some cases, certain species or animal use setting are explicitly excluded from the operation of animal welfare legislation by the adoption of an MCOP, for example, in some instances such as with food or research animals. This shifts the meaning of animal welfare from a wide range of obligations towards animals to a list of specific detailed practices as set out in the MCOP. ${ }^{144}$

While the practices set out in the MCOP are lawful, they would amount to animal cruelty if they were applied in a domestic situation ${ }^{145}$ such as with a companion animal. For example, pigs are exempted from the Prevention of Cruelty to Animals Act 1979 (NSW) as they are defined as 'stock animals' ${ }^{146}$ The result of this exemption and the definition of 'stock animal' ${ }^{147}$ permits the confinement of pigs in some context such as food production. The Model Code of Practice of the Welfare of Animals: Pigs sets the acceptable practice for the confinement of pregnant sows, who typically grow to over $300 \mathrm{~kg}$, and live for long periods in individual gestation metal crates ${ }^{148}$ measuring 60 centimetres in width by 2.2 metres in length. ${ }^{149}$ These practices assume that the pain and suffering experienced by the affected animal meets the definition of 'necessary' and therefore do not constitute animal cruelty for the purpose of the Act ${ }^{150}$ since the MCOP has been adopted in this case under legislation. ${ }^{151}$

137 CAULFIELD, M., Handbook of Australian Animal Cruelty Law (Animals Australia, 2009) 54.

138 National Health and Medical Research Council, Australian Code of Practice of the Care and Use of Animals for Scientific Purposes 8th Edition 2013 (National Health and Medical Research Council, 8th ed, 2013).

139 For example, Australian Standard for the Hygienic Production of Meat and Meat Products for Human Consumption, FRSC Technical Report No. 3, AS 4696: 2007, 21

140 Department of Primary Industries, National Model Codes of Practice for the Welfare of Livestock < http://www.dpi.nsw.gov.au/animals-and-livestock/animal-welfare/general/national>.

141 BRUCE, A., Animal Law in Australia: An Integrated Approach (LexisNexis Butterworths, 2nd ed, 2017) 81.

142 Ibid.

143 McEWAN, A.B., The Concept of Violence: A Proposed Framework for the Study of Animal Protection Law and Policy (PhD Thesis, The Australian National University, 2016) 49.

144 McEWAN, A.B., The Concept of Violence: A Proposed Framework for the Study of Animal Protection Law and Policy (PhD Thesis, The Australian National University, 2016) 49.

145 Ibid.

146 Prevention of cruelty to animals Act 1979 (NSW) s 9.

147 Ibid s. 4 defines stock animals as 'stock animal means an animal which belongs to the class of animals comprising cattle, horses, sheep, goats, deer, pigs, poultry and any other species of animal prescribed for the purposes of this definition'.

148 A sow stall (also known as a gestation stall) is a highly confining type of housing that pregnant pigs on some farms are kept in. A sow stall is roughly the length and width of a fully grown sow (a female breeding pig), and does not allow the sow to turn around or leave. The sow is traditionally housed in a stall for some or all of her pregnancy, which lasts for approximately 115 days. Australian Pork, Industry Focus: Housing < http://australianpork.com.au/industry-focus/animal-welfare/housing/>.

149 Primary Industries Standing Committee, Parliament of Australia, Model Code of Practice for the Welfare of Animals: Pigs (PISC Report 92, Commonwealth of Australia, 3rd Edition, 2008) Appendix 3.

150 CAULFIELD, M., Handbook of Australian Animal Cruelty Law (Animals Australia, 2009) 53.

151 Prevention of Cruelty to Animals Act 1979 (NSW) schedule1 
Table 1 lists the legal status of the MCOP under Animal Welfare Acts for the states of NSW, Victoria and WA. These states are chosen as the case study jurisdictions for this research for the following reasons:

With regard to NSW, historically, it is the State where the largest number of farms and slaughterhouses existed following the launch of the domestic rabbit meat industry. ${ }^{152}$ Victoria is home to many intensive rabbit farms. ${ }^{153}$ Western Australia was the first state to lift the ban on the prohibition on farming domestic rabbits and is home to the first Australian intensive rabbit meat farm (1987) which is still in operation. ${ }^{154}$

\begin{tabular}{|c|c|c|}
\hline State \& Act & Relevant Provisions & Legal effect of noncompliance \\
\hline $\begin{array}{l}\text { NSW } \\
\text { Prevention of } \\
\text { Cruelty to Animals } \\
\text { Act } 1979 \text { (NSW) }\end{array}$ & $\begin{array}{l}\text { s34A(1) 'The regulations may prescribe } \\
\text { guidelines, or may adopt a document in the } \\
\text { nature of guidelines or a code of practice as } \\
\text { guidelines, relating to the welfare of } \\
\text { species of farm or companion animals.' } \\
\text { s34A(4) 'A document adopted as referred } \\
\text { to in subsection (1) may be adopted wholly } \\
\text { or in part, with or without modification and } \\
\text { as in force at a particular time or as in force } \\
\text { from time to time.' }\end{array}$ & $\begin{array}{l}\text { s34A(3) Compliance, or failure to comply, with } \\
\text { any guidelines prescribed or adopted by the } \\
\text { regulations is admissible in evidence in } \\
\text { proceedings }\end{array}$ \\
\hline $\begin{array}{l}\text { Vic } \\
\text { Prevention of } \\
\text { Cruelty to Animals } \\
\text { Act } 1986 \text { (Vic) })^{156}\end{array}$ & $\begin{array}{l}\text { s7(1): The Governor in Council, on the } \\
\text { recommendation of the Minister, may } \\
\text { make, vary or revoke Codes of Practice } \\
\text { s42(2) (d): may apply, adopt or incorporate } \\
\text { (with or without modification)- (i) the } \\
\text { provisions of any document, code, standard } \\
\text { etc. }\end{array}$ & $\begin{array}{l}\text { s6(1)(b): code of practice used as a defence } \\
\text { under this Act. }\end{array}$ \\
\hline $\begin{array}{l}\text { WA } \\
\text { Animal Welfare Act } \\
2002(\text { WA) }\end{array}$ & $\begin{array}{l}\text { S94(2): 'regulations* made under this } \\
\text { section may - (d) adopt codes of practice } \\
\text { relating to the use, care, welfare, safety or } \\
\text { health of animals either - (i) as modified } \\
\text { by the regulations; (ii) as they exist at a } \\
\text { particular date; or (iii) as they are amended } \\
\text { from time to time;' } \\
\text { *Animal Welfare (General) Regulations } \\
\text { 2003, r6\&schedule1 }\end{array}$ & $\begin{array}{l}\text { s25. 'Defence - code of practice It is a defence } \\
\text { to a charge under section } 19(1) \text { for a person to } \\
\text { prove that the person was acting in accordance } \\
\text { with a relevant code of practice.' }\end{array}$ \\
\hline
\end{tabular}

Table (1) Adoption of MCOP under Animal Welfare Acts in NSW, Vic and WA

Having set out the major aspects of the animal welfare regime, the following section considers the concept of animal welfare from a scientific point of view.

\subsection{The Contemporary Approach to Animal Welfare Science in Australia}

There is a large body of animal welfare science literature and an exhaustive review is beyond the scope of this work. ${ }^{158}$ Instead this section summarises some of the different approaches to animal welfare science with the aim of informing the reader of the foundations for current animal welfare protection laws, which will be the subject of the critique in Chapter Four.

152 SHIM-PRYDON, G., et al, New Animal Products New uses and markets for by-products and coproducts of crocodile, emu, goat, kangaroo and rabbit (2007) 06/117 Rural Industries Research and Development Corporation Publication, 1-65.

153 Freedom for Farmed Rabbits Inc., Cruelty Evidence $(2018)<$ http://www.freedomforfarmedrabbits.com.au/farms/crueltyevidence/>.

154 FOSTER, M., Emerging animal and plant industries: their value to Australia (2014) 14/069 Rural Industries Research and Development Corporation Publication, 42.

155 Prevention of Cruelty to Animals Act 1979 (NSW) s34(A).

156 Prevention of Cruelty to Animals Act 1986 (Vic) s7(1);s42(2);s6(1).

157 Animal Welfare Act 2002 (WA) s94(2);s25.

158 See for example BROOM, D.M., Cognitive ability and awareness in domestic animals and decisions (2010) 126 Applied Animal Behaviour Science, 1-11; BROOM, D.M., Animal Welfare Defined in Terms of attempts to cope with the environment (1996) 27 Acta Agric. Scam/ Sect/ A, Animal Sci Suppl., 22-28; BROOM, D.M., Animal welfare: concepts and measurement (1991) J. Auh Sci, 4167-4175; BROOM, D.M., Indicators of poor welfare (1986) 142 British Veterinary Journal, 524-526.; BROOM, D.M., Considering animals' feelings (2016) 005Animal Sentience; DUNCAN, I.J.H., Welfare is to do with what animals feel (1993) Jrnl of Agricultural and Environmental Ethics; DAWKINS, M., Through animal eyes: What behaviour tells us (2006) 100 Applied Animal Behaviour Science, 4-10. 
Prior to the mid-1980s, the term 'animal welfare' was not defined nor considered a science. ${ }^{159}$ Broom defined the term animal welfare in 1986 as ' $[\mathrm{t}]$ he welfare of an individual [animal] is its state as regards its attempts to cope with its environment'. ${ }^{160}$ Broom described 'coping ${ }^{161}$ as the mental and physical stability of an animal as indicated by scientific measurements ${ }^{162}$ which can range from very good to very poor welfare. ${ }^{163}$ In the early 1990s, it was agreed amongst animal welfare scientists that animal welfare describes a measurable quality of a living being ${ }^{164}$ and hence animal welfare became a scientific concept. ${ }^{165}$

From 2006-2014, Australia had a Commonwealth Government initiative the (now outdated) Australian Animal Welfare Strategy (AAWS) with a major objective to develop and implement animal welfare standards with strong scientific basis. ${ }^{166}$ The AAWS adopted the World Organisation for Animal Health's (OIE) definition of Animal welfare ${ }^{167}$ which incorporates Broom's concept of 'coping'. ${ }^{168}$ According to the OIE:

'[A]nimal welfare means how an animal is coping with the circumstances in which it lives. An animal is in a good state of welfare if (as indicated by scientific evidence) it is healthy, comfortable, well nourished, safe, able to express innate behaviour, able to have normal social contact with others of the same species, and if it is not suffering from unpleasant states such as pain, fear, and distress. Good animal welfare requires disease prevention and veterinary treatment, proper housing, management, nutrition, humane handling and humane slaughter/killing. By scientific convention, 'animal welfare' refers to the state of the animal; the treatment that an animal receives is covered by other terms such as animal care, animal husbandry, and humane treatment. ${ }^{169}$

Disagreements about the extent of concerns humans should have towards animal welfare mostly depend on the stakeholders ${ }^{170}$ and have led to a variety of approaches to animal welfare science and subsequent interpretation of results. ${ }^{171}$ Animal welfare scientist Fraser assembles these concerns under three broad groups: ${ }^{172}$ those who emphasize the affective states of animals such as pain, distress and pleasure experienced as negative or positive states; ${ }^{173}$ those who emphasize the ability of animals to lead reasonably natural lives by carrying out natural behaviour; ${ }^{174}$ and the basic health and biological functioning of an animal such as freedom of disease and injury. ${ }^{175}$ For example, livestock industries prioritise the 'basic health and functioning' concept of animal welfare over those of 'affective states' and 'natural living'. ${ }^{176}$ Farmers tend to believe that health and productivity of animals such as rapid growth and high productivity performance are the main indicators of good welfare. As a result, animals in confinement are seen to have good welfare. ${ }^{177}$ Some veterinarians defend this belief whereby the animals are better cared for, with shelter, bedding, food and water

159 BROOM, D.M., A History of Animal Welfare Science (2011) 59 Acta Biotheoretica 121,124.

160 BROOM, D.M., Indicators of poor welfare (1986) 142 British Veterinary Journal, 524-526.

161 BROOM, D.M., The scientific assessment of animal welfare (1988) 20 Appl Anim Behav Sci, :5-19; BROOM, D.M., Animal welfare: concepts and measurement (1991) 69 J Animal Science 4167-4175.

162 The main welfare measurements according to Caulfield are physiological changes, behaviour, health status, injury, growth and reproduction and life expectancy. CAULFIELD, M., Animals in Australia (Vivid Publishing, 2018) 41.

163 BROOM, D.M., Animal Welfare defined in terms of attempts to cope with the environment (1996) 27 Acta. Agric.Scand., Sect. A, Animal Sci.,24.

164 BROOM, D.M., A History of Animal Welfare Science (2011) 59 Acta Biotheoretica 121,122.

165 Ibid 127.

166 CAULFIELD, M., Handbook of Australian Animal Cruelty Law (Animals Australia, 2009) 55

167 Department of Agriculture and Water Resources, Australian Animal Welfare Strategy-AAWS and National Implementation Plan 2010-14,

$<$ http:/www.agriculture.gov.au/animal/welfare/aaws/australian-animal-welfare-strategy-aaws-and-national-implementation-plan2010-14>.

168 World Organisation for Animal Health, A new definition for the Terrestrial Animal Health Code: 'animal welfare $<$ http://www.oie.int/doc/ged/D5517.pdf $>$.

169 Ibid .

170 Stakeholders include farm suppliers, farmers, food and processing industries, retailers, consumers, public authorities, researchers and non-governmental organisations. VERBEKE, W., Stakeholder, citizen and consumer interests in farm animal welfare (2009) 18 Animal Welfare, 325.

171 FRASER, D., A scientific conception of animal welfare that reflects ethical concerns (1997) 6 Animal welfare, 187-205.

172 FRASER, D., Understanding animal welfare (2008) 50:S1 Acta Veterinaria Scandinavica.

173 The term 'Affective' refers to emotions and other feelings that are experienced as pleasant or unpleasant. FRASER, D., Understanding animal welfare (2008) 50:S1 Acta Veterinaria Scandinavica.

174 'whether the animal is living a natural life - is qualified by asking whether the animal is in an environment consistent with one in which the species evolved and to which it has adapted'. CAULFIELD, M., Animals in Australia (Vivid Publishing, 2018 ) 41.

175 FRASER, D., Understanding animal welfare (2008) 50:S1 Acta Veterinaria Scandinavica.

176 GOODFELLOW, J., Animal welfare regulation in the Australian agricultural sector: a legitimacy maximising analysis $(\mathrm{PhD}$ thesis, Macquarie University, 2015) 85.

177 SERPELL, J.A., Sheep in wolves' clothing? Attitudes to animals among farmers and scientists, in DOLINS, F.L. (ed.), Attitudes to Animals: Views in Animal Welfare. (Cambridge University Press,1999) 27-28. 
and are free of disease. ${ }^{178}$ Ethologists on the other hand favour observations on animals in conditions that are as close as possible to their natural environment. ${ }^{179}$

Of the three approaches to animal welfare studies, the biological functioning was initially the most dominant in welfare science ${ }^{180}$ and emphasised physical, physiological and functional states but not the affective states of the animals. It focused on assessing the difficulties in achieving biological fitness, ${ }^{181}$ resilience and performance. ${ }^{182}$ As the motivational preference tests of animals became objects of scientific studies, ${ }^{183}$ the affective state approach, in particular to animal motivations, preferences and aversions, gained attention. ${ }^{184}$ The natural living approach is a reference point used to estimate good experiences animals may have whereby human-imposed environmental restrictions are excluded. ${ }^{185}$ Within the past decade, biological function and affective state approaches have integrated and are considered to be fundamental to managing and improving animal welfare. ${ }^{186}$

In Australia, the 'biological functioning' approach has been dominant, with a lack of emphasis on the measures assessing individual animal experiences or effects. ${ }^{187}$ The position of the Animal Welfare Science Centre (AWSC) at the University of Melbourne, which is the leading group in animal welfare science in Australia, ${ }^{188}$ endorses that an animal's 'fitness', which can be measured by reproductive performance, is useful to the examination of the state of the animal's welfare. ${ }^{189}$ This view also underpins the view of the Australian Royal Society for the Prevention of Cruelty to Animals (RSPCA) who state that '[R]SPCA Australia considers that the welfare of an animal includes its physical and mental state and that good animal welfare implies both fitness and a sense of well-being' ${ }^{190}$ However, according to Verga, an expert in rabbit welfare science, the coping strategy of rabbits in the wild and on farms allows them to reproduce well. ${ }^{191}$ Therefore from a production and fitness level, rabbits may seem to cope with their artificial environments fairly well, however Verga argues that this does not mean that their welfare has not been adversely affected. ${ }^{192}$ This is contrary to the position taken in Australia as discussed above.

The Animal Welfare Science Centre's (AWSC) view has also been that there is little evidence that a behavioural change, such as bar gnawing occurring in confined animals, is associated with a reduction in 'fitness' ${ }^{193}$ Such a stereotypic behaviour according to the AWSC is regarded as a coping mechanism to environmental changes which is not classified as a negative state of welfare. ${ }^{194}$ However, according to biologist and ethologist Marc Bekoff, stereotypies such as bar gnawing are a direct outcome of captivity, as they are completely absent in the wild and imply a negative state of welfare. ${ }^{195}$

The lack of any reference to species-specific behavioural based science in the application of animal welfare in Australia, as shown in the preliminary examples above, suggests a lack of proper consideration of animal wellbeing. This forms the basis of my use of Bekoff and Pierce's ethological approach, based on behavioural science to assess meat rabbits' wellbeing in practice. This is key to allow assessment of welfare

178 TAYLOR, G.B., One man's philosophy of welfare (1972) 91 Vet Rec,426-428.

179 BEKOFF, M.- ALLEN, C., Cognitive Ethology: Slayers, Skeptics and Proponents, in R. W. Mitchell et al (eds) Anthropomorphism, Anecdotes and Animals: The Emperor' New Clothes? (Eds) New York, State University Press. (1997) 314.

180 MELLOR, D., Updating Animal Welfare Thinking: Moving beyond the "Five Freedoms" towards “A Life Worth Living” (2016) 6 Animals, 14.

181 The more offspring an organism produces during its lifetime, the greater its biological fitness.

182 MELLOR, D., Updating Animal Welfare Thinking: Moving beyond the "Five Freedoms" towards "A Life Worth Living" (2016) 6 Animals, 14.

183 Preference testing gives an animal a choice to test their preferences between alternatives such as flooring. See for example DAWKINS, M., Cage size and flooring preferences in litter-reared and cage-reared hens (2007) 24:2 British Poultry Science, 177182.

184 MELLOR, D., Updating Animal Welfare Thinking: Moving beyond the "Five Freedoms" towards “A Life Worth Living” (2016) 6 Animals, 14

185 Ibid.

186 HEMSWORTH, P. et al, Scientific assessment of animal welfare (2015) 63(1) New Zealand Veterinary Journal, 24-30.

187 CAULFIELD, M., Animals in Australia (Vivid Publishing, 2018) 41.

188 According to Caulfield, this group has been the leading group in animal welfare science in Australia, led by Prof Hemsworth and has received much of its funding from primary industry (meat and livestock Australia; Dairy Australia; Australian Wool Innovation; the Australian Egg Corporation and Australian Pork limited). CAULFIELD, M., Animals in Australia (Vivid Publishing, 2018) 8889.

189 CAULFIELD, M., Animals in Australia (Vivid Publishing, 2018) 89.

190 RSPCA, Five freedoms for animals (12 Jun 2009) <http://kb.rspca.org.au/five-freedoms-for-animals_318.html>.

191 VERGA, M. et al, Welfare aspects in rabbit rearing and transport (2009) 8(1) Italian Journal of Animal Science, 193.

192 Scientific Panel on Animal Health and Welfare, 'The Impact of the current housing and husbandry systems on the health and welfare of farmed domestic rabbits' (2005) 267 The EFSA Journal, 24.

193 CAULFIELD, M., Animals in Australia (Vivid Publishing, 2018) 89.

194 Ibid.

195 BEKOFF, M.- PIERCE, J., Animals' Agenda: Freedom, Compassion, and Coexistence in the Human Age (Beacon Press, 2017) 
from the animal's point of view and will be used as a reference point for analysis of current animal welfare standards in Chapter Four.

In addition to considering the animal's welfare in terms of 'fitness', the RSPCA and Animal Health Australia (AHA), the national body responsible for developing the new Standards and Guidelines set to replace the MCOP ${ }^{196}$ state that animal welfare can be based on an assessment of an animal's physical and psychological state with respect to the provisions of the Five Freedoms as follows: ${ }^{197}$

The Five Freedoms, as listed by RSPCA Australia, are:

1. Freedom from hunger and thirst: by ready access to fresh water and a diet to maintain full health and vigour;

2. Freedom from discomfort: by providing an appropriate environment including shelter and a comfortable resting area;

3. Freedom from pain, injury or disease: by prevention through rapid diagnosis and treatment;

4. Freedom to express normal behaviour: by providing sufficient space, proper facilities and company of the animal's own kind; and

5. Freedom from fear and distress: by ensuring conditions and treatment which avoid mental suffering. ${ }^{198}$

\subsection{Conclusions}

This chapter provided an overview of Australia's animal welfare regime. The Model Codes of Practice for the welfare of animals (MCOP) were introduced. They set minimum standards of animal welfare and husbandry practices for major farmed species such as the intensive husbandry of rabbits. The legal status of MCOPs depends on whether the States or Territories apply them as law. Those which are not adopted into anticruelty legislation but are complied with anyway may provide an exemption to a charge of animal cruelty or compliance, may be submitted as evidence or may be used as a defence to a charge of cruelty. ${ }^{199}$

An overview of the most common animal welfare science approach in Australia was provided. This is based on fitness and biological functioning rather than behaviour. I also introduced the animal welfare concept of the Five Freedoms which underpins the definition of animal welfare under the RSPCA.

Chapter Three identifies how the current animal welfare regime summarised in this chapter protects domestic rabbits under different contexts of human use as part of examining how the domestic rabbit is regulated. In addition, the provisions of husbandry within the Model Code of Practice for the Welfare of Animals: Intensive Husbandry of Rabbits (MCOPIHR) ${ }^{200}$ will be evaluated against the provisions in the Guidelines for the Care and Housing of Rabbits in Scientific Institutions. ${ }^{201}$ This shows the differences between rabbit welfare practices under separate industries based on one species.

\section{Chapter 3. Analysis of the Regulatory Framework of the Domestic Rabbit in Australia}

The aim of this chapter is to examine the regulation of the domestic rabbit industry and analyse the animal welfare regime as applied to domestic rabbits under different human uses with a view to identify the effectiveness of these standards.

In doing this analysis, I am adopting Garner's perspective on incremental reform ${ }^{202}$ which is based on using current knowledge in animal welfare as a social driver for a moral shift to change legislation. ${ }^{203}$ As the Australian animal welfare laws pertaining to domestic rabbits is an area which has not been analysed or explored, current animal welfare laws, statutes, standards and codes of practice applied to the domestic rabbit examined in this Chapter and Chapter Four will contribute to the current knowledge of protection the domestic

196 AHA defines itself as 'a not-for-profit public company that facilitates innovative partnerships between governments, major livestock industries and other stakeholders to protect animal health and the sustainability of Australia's livestock industry. Animal Health Australia, About Us (19 July 2018) <https://www.animalhealthaustralia.com.au/who-we-are/company-profile/>

197 Animal Health Australia, About Us (19 July 2018)<https://www.animalhealthaustralia.com.au/who-we-are/company-profile/>. 198 RSPCA, Five freedoms for animals (12 Jun 2009) <http://kb.rspca.org.au/five-freedoms-for-animals_318.html .

199 McEWAN, A.B., The Concept of Violence: A Proposed Framework for the Study of Animal Protection Law and Policy (PhD Thesis, The Australian National University, 2016) 49.

200 CSIRO Publishing and Primary Industry Standing Committee (Cth), Model Code of Practice for the Welfare of Animals: Intensive Husbandry of Rabbits (Primary Industries Report Series 33, 2003).

201 Department of Agriculture (NSW) ARRP Guideline 18: Guidelines for the Housing of Rabbits in Scientific Institutions, 2003 (State of New South Wales, 2003) <https://www.animalethics.org.au/_data/assets/pdf_file/0013/222511/housing-rabbits-scientificinstitutions.pdf>.

202 GARNER, R., Political Ideology and the legal status of animals (2002) Animal Law 8, 80.

203 Ibid. 
rabbit falls under and highlight specific areas of needed reform.

The domestic rabbit is regulated under a range of statutes. It is beyond the scope of this work to analyse all their uses and within different States and Territories. For the purposes of this work, the analysis is confined to those industries in which rabbits are most commonly used and caged or bred within cages. Caging animals in conditions of extreme confinement such as rabbits used for meat in intensive farms carries with it serious welfare concerns as animals are known to experience physical and psychological suffering ${ }^{204}$ and are unable to express natural behaviour. ${ }^{205}$ It is within the context of cages that this thesis focuses on whether animal welfare can meet the wellbeing requirements of rabbits.

I examine rabbits raised and used in three industries: caged rabbit meat industry, research, and rabbits as pets/companion animals. Rabbits used in these industries have several commonalities such as:

- The rabbits live most of their lives in cages;

- Rabbits used in research and the meat industries are mainly one breed of rabbit, the New Zealand White. ${ }^{206}$ The New Zealand White is a medium sized breed of domesticated rabbit, mostly bred for rabbit meat ${ }^{207}$ and scientific research industries. ${ }^{208}$ Having the same breed of rabbit makes the animal welfare comparison aspects easier for identically sized rabbits. The New Zealand Breed is also commonly used within the pet industries. ${ }^{209}$

The examination is confined to three States: Victoria (Vic), New South Wales (NSW) and Western Australia (WA). Those states were chosen for the following reasons:

With regard to NSW, historically, it is the State where the largest number of farms and slaughterhouses existed following the launch of the domestic rabbit meat industry. ${ }^{210} \mathrm{NSW}$ currently houses one of the largest operating rabbit farms/slaughterhouses in Australia which farms rabbits for meat and fur [Akubra hats]. ${ }^{211}$ In 2016, the independent State Minister for Sydney (NSW), MP Alex Greenwich, spoke publicly about the need to introduce a bill banning rabbit meat farms after cruel conditions for rabbits reared in intensive meat farms appeared publicly on television, ${ }^{212}$ indicating that the NSW rabbit meat industry should be examined more closely.

Today, Victoria is home to many intensive rabbit farms. ${ }^{213}$ Footage from several farms provides the opportunity to analyse animal welfare practices within the industry.

Western Australia was the first state to lift the ban on the prohibition on farming domestic rabbits and is home to the first Australian intensive rabbit meat farm (1987) which is still in operation. ${ }^{214}$ Footage of the aforementioned farm is also available for animal welfare analysis in practice. ${ }^{215}$

This chapter is divided into two parts:

Part One provides an overview of the history of the rabbit in Australia. It offers an understanding of the place of the rabbit in Australian culture and how current attitudes towards this species have been shaped. Part One also examines early legislation that saw the rabbit declared a 'pest' and the gradual emergence of the rabbit meat industry as well as the introduction of caged enclosures for personal and commercial purposes.

204 BEKOFF, M.- PIERCE, J., The Animals' Agenda: Freedom, Compassion and coexistence in the Human Age (Beacon Press, 2017)37.

205 'Freedom to express normal behaviour: by providing sufficient space, proper facilities and company of the animal's own kind' is the fourth welfare Freedom as listed by the RSPCA. RSPCA, Five freedoms for animals (12 Jun 2009) < http://kb.rspca.org.au/fivefreedoms-for-animals $318 . \mathrm{html}>$.

206 For breed traits see Cross Roads Rabbitry, New Zealand Whites $<$ http://www.crossroadsrabbitry.com/about-new-zealand-whiterabbits/>.

207 A survey of rabbit farmers in NSW in 1999 showed that the predominant breed of meat rabbit is the New Zealand White. The Crusader research program for the development of intensive rabbit meat in Australia have also selected the NZ White for fastest growth traits. EADY, S., Farmed Rabbits in Australia (2003) 02/144 Rural Industries Research and Development Corporation Publication.

208 SUEN, W.W. et al, Experimental West Nile Virus Infection in Rabbits: An Alternative Model for Studying Induction of Disease and Virus Control (2015) 4 Pathogens, 529-558.

209 For breed traits see $<$ http://www.crossroadsrabbitry.com/about-new-zealand-white-rabbits/>.

210 SHIM-PRYDON, G. et al, New Animal Products New uses and markets for by-products and coproducts of crocodile, emu, goat, kangaroo and rabbit (2007) 06/117 Rural Industries Research and Development Corporation Publication, 1-65.

211 LANE, K., Hop to it - its dinner time, Sydney Morning Herald (online) 23 May 2010

$<$ https://www.smh.com.au/entertainment/hop-to-it---its-dinner-time-20100522-w32v.html>

212Channel Seven, 'The disturbing reality behind caged rabbits bred for their meat', 7News, 18 September 2016 (Bryan Seymour) $<$ https://au.news.yahoo.com/the-disturbing-reality-behind-caged-rabbits-bred-for-their-meat-32652779.html\#page1>

213 Freedom for Farmed Rabbits Inc., Cruelty Evidence (2018) < http://www.freedomforfarmedrabbits.com.au/farms/crueltyevidence/>.

214 FOSTER, M., Emerging animal and plant industries: their value to Australia (2014) 14/069 Rural Industries Research and Development Corporation Publication, 42.

215 Aussie Farms, Baldivis Rabbits (2016) < https://www.aussiefarms.org.au/facilities/da16d-baldivis-rabbits>.

124 Derecho Animal. Forum of Animal Law Studies, vol. 10/2 
Part Two provides an analysis of animal welfare laws and practices in the rabbit meat, research and pet industries in NSW, Vic and WA, with an aim to identify the protection framework that rabbits fall under.

In section 3.3 I investigate how domestic rabbit industries are regulated and how animal welfare legislation is applied depending on the context of use. I look at how rabbits are defined under each of the use industries and how that drives the animal welfare laws. For example, as a non-economic being, such as a companion animal, a rabbit will be protected directly by animal welfare Acts. However, under economic uses, such as food and research, rabbits might be excluded from the animal welfare Acts either directly or indirectly through mandated codes of practice or standards.

In section 3.4, I present two examples to illustrate how the animal welfare laws applied in different contexts of use (as shown in section 3.3) can be discriminatory towards the same species. Through this analysis, I identify issues in animal welfare, one of which is the inconsistent character of animal protection laws in their application of protection to rabbits under human use.

\section{PART ONE: History}

\subsection{The History of Rabbits in Australia: A Snapshot}

The European rabbit (Oryctolagus Cuniculus) $)^{216}$ is a variety of rabbit species belonging to the family of Lagomorphs (Hare-Form) originating in Europe ${ }^{217}$ Domestic European rabbits were introduced in Australia in 1788 with the first fleet, ${ }^{218}$ as an attempt by early settlers to 'enhance' Australia with meat animals from the 'Old Country'. ${ }^{219}$ In 1859, 24 wild European rabbits were introduced for sport and hunting by pastoralist Thomas Austin. It was after this event that the rabbit populations grew out of control. ${ }^{220}$ By 1862 wild rabbits were in their thousands. ${ }^{221}$ In addition, between 1860-1870 many importers of rabbits released them for hunting purposes on the East Coast of Australia. ${ }^{222}$ Across the continent, in Western Australia, rabbits were imported from the East Coast of Australia between 1882-1893. ${ }^{223}$ Within 50 years, rabbit populations had spread across two thirds of the Australian continental land mass. ${ }^{224}$

By 1870, while rabbits were creating economic gains for some trappers and hunters through the sale of rabbit skins and carcasses, ${ }^{225}$ significant economic losses were experienced by the agricultural sector due to the loss of pasture areas for cattle and sheep and wool production. ${ }^{226}$ This saw a push for the introduction of legislation to control rabbits. ${ }^{27}$ In 1871 Tasmania introduced its first legislation aimed at the destruction of all rabbits. ${ }^{228}$ Other states followed: South Australia in $1875,{ }^{229}$ Victoria in $1878,{ }^{230}$ New South Wales, ${ }^{231}$ Queensland in $1880^{232}$ and Western Australia in $1883 .{ }^{233}$ These pieces of legislation made it compulsory for landholders to destroy all rabbits on their farms and made it illegal to keep, introduce or breed rabbits. ${ }^{234}$

In Australia, the first piece of legislation referring to the rabbit as a 'pest species' was the Rabbit

216 European rabbits live in complex underground warrens, hence the name Oryctolagus 'digging in Latin' and Cuniculus 'underground passage'.

217 The European rabbit 'Oryctolagus cuniculus' have their origins in Spain, Portugal and areas of North Africa. The International Union for Conservation of Nature, Species $<\mathrm{https}$ ://www.iucn.org/theme/species>.

218 Governor Phillip is thought to be the first importer of domesticated rabbits in Australia. Brian Coman, Tooth and Nail: The Story of the Rabbit in Australia (Text Publishing, 1999).

219 COMAN, B., Tooth and Nail: The Story of the Rabbit in Australia (Text Publishing, 1999).

220 Ibid.

221 Ibid.

222 According to Coman shooting of small game animals was a very popular sport of that era. COMAN, B., Tooth and Nail: The Story of the Rabbit in Australia (Text Publishing, 1999)

223 COMAN, B., Tooth and Nail: The Story of the Rabbit in Australia (Text Publishing, 1999).

224 Ibid.

225 EATHER, W.- COTTLE, D., The Rabbit Industry in South-East Australia, 1870-1970 (Paper presented at the 14th Biennial Labour History Conference, Melbourne, 2015).

226 Invasive Animals Cooperative Research Centre, The economic impacts of vertebrate pests in Australia

$<$ https://www.pestsmart.org.au/wp-content/uploads/2010/03/IACRC_EconomicImpactsReport.pdf $>$.

227 COMAN, B., Tooth and Nail: The Story of the Rabbit in Australia (Text Publishing, 1999)

228 Rabbit Destruction Act 1871 (TAS)

229 Rabbit Destruction Act 1875 (SA)

230 Rabbit Nuisance Suppression Act 1878 (Vic)

231 Pastures and Stock Protection Act 1880 (NSW)

232 Rabbit Act of 1880 (Qld).

233 Destruction of Rabbits Act 1883 (WA)

234 EATHER, W.- COTTLE, D., The Rabbit Industry in South-East Australia, 1870-1970, Proceedings of the 14th Biennial Labour History Conference, eds, Phillip Deery and Julie Kimber (Melbourne: Australian Society for the Study of Labour History, 2015), 120. 
Nuisance Suppression Act 1878 (Vic). ${ }^{235}$ In NSW, the Rabbit Nuisance Act 1883 (NSW) ordered the destruction of rabbits on private land ${ }^{236}$ and introduced heavy fines and imprisonment as penalties for any person possessing a live rabbit. ${ }^{237}$ Under the Rabbit Nuisance Act 1883 (NSW) the proclamation of the "natural enemy of the rabbit' was established by the Governor of the District which prohibited killing or capturing any animals which were considered a natural enemy of the rabbit without a special permit. ${ }^{238}$

Rabbits are declared 'pests' in all Australian Jurisdictions. ${ }^{239}$ The current status of rabbits as 'pests' places rabbits at the bottom of our realm of moral consideration. They have become a maligned animal in Australian culture. This may be an important reason that they are a relatively neglected species when it comes to animal protection advocacy and public interest in their welfare.

Provisions aimed at controlling rabbit populations have moved into the state and territory land Acts, which require landowners to take action to control rabbits on their land ${ }^{240}$ with methods such as gassing and ripping of warrens, shooting, trapping, and the uses of biological agents Pindone ${ }^{241}$ and $1080 .{ }^{242}$ In addition, local councils release deadly viruses annually to control wild rabbits including several variants of the Rabbit Haemorrhagic Disease (RHD), also known as Rabbit Calicivirus and Myxomatosis. ${ }^{243}$ In Queensland, the ownership of rabbits (all varieties, including domestic breeds) is prohibited under the Biosecurity Act 2014 (Qld). ${ }^{244}$ A permit cannot be issued for keeping companion rabbits of any variety unless for an approved purpose of certain forms of public entertainment such as magic shows and for use in scientific research. ${ }^{245}$

\subsection{Pet, Pest \& Profit: The Evolution of Rabbit Legislation for Commercial Use}

Between 1870 and 1970 over 20 billion wild rabbits were trapped or poisoned in southeast Australia ${ }^{246}$ for commercial purposes. ${ }^{247}$ The wild rabbit industry consisted of trapping ${ }^{248}$ meat carcasses, skin and fur trades, exports, canning and freezer-works. ${ }^{249}$ The freezer-works were located in rural towns and capital cities. New South Wales and Victoria employed thousands of workers for the purposes of grading, sorting, packing, skinning and transporting rabbit carcases. ${ }^{250}$

Unlike other rural industries such as wool, the wild rabbit industry thrived during war, depression and drought. ${ }^{251}$ By the late 1920s the rabbit industry in south-eastern Australia was one of the largest employers of labour in the country. ${ }^{252}$

The following subsections identify key legislation changes which allowed for the commercialisation of

235 Rabbit nuisance suppression Act 1878 (Vic) .

236 Rabbit Nuisance Act 1883 (NSW) sections 8, 9, 11.

237 Ibid s36.

238 Ibid s 31

239 Game and Feral Animal Control Act 2002 (NSW); Local Lands Services Act 2013 (NSW); Catchment and Land Protection Act 1994 (Vic); Biosecurity and Agriculture Management Act 2007 (WA); Pest Plants and Animals Act 2005 (ACT); Territory Parks and Wildlife Conservation Act 2006 (NT); Natural Resources Management Act 2004 (SA); Land Protection (Pest and Stock Route Management) Act 2002 (Qld); Vermin Control Act 2000 (Tas).

240 Department of Environment and Energy, Threat abatement plan for competition and land degradation by rabbits $<$ https://www.environment.gov.au/system/files/resources/bf9352c2-35ae-4a80-8828-96de630731a9/files/tap-rabbit-background2016.docx>.

241 Pindone is a first-generation anticoagulant that acts by blocking the synthesis of vitamin K-dependent clotting factors, which causes fatal haemorrhages in susceptible animals. BEDER, S.- GOSDEN, R., Pindone Rabbit-Baiting: Cruel and Careless? (2011) UoW Discussion Paper $<$ https://www.uow.edu.au/ sharonb/PindoneDiscussion.pdf $>$.

242 1080, Sodium fluoroacetate, is an odourless, tasteless white powder that has a special dye added for identification of the toxin. It is used for poisoning of rabbits by incorporating it into a suitable bait material. Centre for Invasive Species Solution, RAB002: Ground baiting of rabbits with 1080, <https://www.pestsmart.org.au/ground-baiting-of-rabbits-with-1080/>.

243 See Draft model code of practice for the humane control of rabbits 2012. Centre for Invasive Species Solution, Model code of practice for the humane control of rabbits <https://www.pestsmart.org.au/wp-content/uploads/2012/09/rabbitCOP2012.pdf>.

244 Biosecurity Act 2014 (Qld)Schedule 2.

245 Queensland Department of Agriculture and Fisheries, Can I Have a Pet Rabbit

$<$ https://www.daf.qld.gov.au/_data/assets/pdf_file/0009/57780/IPA-Keeping-Rabbits-As-Pets-PA15.pdf>.

246 South East Australia encompasses southern Queensland, New South Wales (NSW), Victoria, Tasmania and eastern South Australia.

247 EATHER, W.- COTTLE, D., The Rabbit Industry in South-East Australia, 1870-1970 (Paper presented at the 14th Biennial Labour History Conference, Melbourne, 2015) 1.

248 Trapping attracted the majority of the workers, and was done for carcases or skins, or poisoning for skins. EATHER, W.COTTLE, D., The Rabbit Industry in South-East Australia, 1870-1970 (Paper presented at the 14th Biennial Labour History Conference, Melbourne, 2015)

249 EATHER, W.- COTTLE, D., The Rabbit Industry in South-East Australia, 1870-1970 (Paper presented at the 14th Biennial Labour History Conference, Melbourne, 2015) 1.

250 Ibid.

251 Ibid.

252 Ibid.

126 Derecho Animal. Forum of Animal Law Studies, vol. 10/2 
domestic rabbits in the states of Victoria, New South Wales and Western Australia.

\subsubsection{Commercialisation of the Rabbit: Key Legislative Changes in Victoria}

Despite the enactment of legislation aimed at eliminating the rabbit from Australia, the Victorian Agricultural Department, realising the future economic prospect of the export trade for frozen rabbit carcasses to England, enabled the trade by providing facilities for grading, inspection, freezing and storage at minimum wage to private firms and trappers. ${ }^{253}$ It has been estimated that Victoria exported up to 10.5 million skins a year in the 1890s. ${ }^{254}$

However, the rabbit export industry declined significantly by 1951 after the release by the Commonwealth Scientific and Industrial Research Organisation (CSIRO) of the myxomatosis virus, to control rabbit numbers. Large amounts of money were made available by the Commonwealth and State governments and rural industries to fund research and the dissemination of myxomatosis during the early $1950 \mathrm{~s} .{ }^{255}$ The advances made in eradicating rabbits were supported by legislation ${ }^{256}$ that gave power to inspectors to control rabbit populations by administering myxomatosis. ${ }^{257}$

The spread of the myxomatosis virus was facilitated by farmers, rabbit inspectors and the Pastures Protection Boards. ${ }^{258}$ By 1953 it was estimated that $80 \%$ of the rabbit population within South East Australia had died from the disease. ${ }^{259}$ The main area where exporters sourced rabbits after the release of myxomatosis virus was from central Australia, which was too dry for the mosquitoes, the vector transmitting myxomatosis, which carry the disease. ${ }^{260}$

In the late 1950s there were attempts to instigate a domestic rabbit meat industry by rabbit breeders, but it was opposed by rabbit control authorities from fear that such an industry would affect rabbit control, and by other farmed meat interests because of the threat of competition from producers of rabbit meat. ${ }^{261}$ The rabbit industry, except for a few breeders who provided rabbits to scientific establishments, collapsed. ${ }^{262}$

The rabbit meat industry was in abeyance for almost four decades. However, in the 1990s, changes to the Meat Industry (Amendment) Regulations 1998 (Vic) prescribed buffalo and the 'rabbit-if not living in wild state' as consumable animals for the purpose of section 3 of the Meat Industry Act 1993(Vic), which previously listed rabbit as game.

\subsubsection{Commercialisation of the Rabbit: Key Legislative Changes in New South Wales}

Unlike Victoria, NSW tried to block the export trade of frozen rabbit carcasses to England in the 1890s mainly due to a lack of inland freezer works, problems with the railroad network, and opposition from farming and grazing interests. ${ }^{263}$ However, due to drought conditions in 1890 and early 1900 s, the NSW Board of Exports decided to start commercialising wild rabbits by arranging an export trade of carcasses with England. ${ }^{264}$

In 1890, the Rabbit Nuisance Act 1883 (NSW) was replaced by the Rabbit Act 1890 (NSW) to facilitate and encourage the erection of rabbit proof fencing to control rabbits ${ }^{265}$ and to make provision for the destruction of rabbits ${ }^{266}$ by 'lawful means' ${ }^{267}$ However, under section 41 of the Rabbit Act 1890 (NSW) the prohibition of keeping domesticated rabbits was lifted. As a result, rabbits were allowed to be kept in a cage

253 Ibid 8.

254 Ibid.

255 COMAN, B., Tooth and Nail: The Story of the Rabbit in Australia (Text Publishing, 1999).

256 See for example, Vermin Destruction Act 1950 (Tas); Agriculture Protection Board Act 1950 (WA).

257 COMAN, B., Tooth and Nail: The Story of the Rabbit in Australia (Text Publishing, 1999).

258 EATHER, W.- COTTLE, D., The Rabbit Industry in South-East Australia, 1870-1970 (Paper presented at the 14th Biennial Labour History Conference, Melbourne, 2015) 2.

259 Ibid.

260 EATHER, W.- COTTLE, D., The Rabbit Industry in South-East Australia, 1870-1970 (Paper presented at the 14th Biennial Labour History Conference, Melbourne, 2015) 2.

261 SOBEY, W.R., Protecting Domestic Rabbits Against Myxomatosis in Australia and the Problems Associated with it Past and Present (Paper presented at Recent Advances in Animal Nutrition, 1981) <http://livestocklibrary.com.au/handle/1234/19383>.

262 Ibid.

263 EATHER, W.- COTTLE, D., The Rabbit Industry in South-East Australia, 1870-1970 (Paper presented at the 14th Biennial Labour History Conference, Melbourne, 2015) 8.

264 Ibid.

265 Rabbit Act 1890 (NSW) s 12.

266 Ibid s 26.

267 'lawful means' is not defined within the legislation. However according to historians, the following methods were used: trapping, ferreting, gassing of burrows, poisoning and hunting. COMAN, B., Tooth and Nail: The Story of the Rabbit in Australia (Text Publishing, 1999) 
for human use with the permission of the Minister. ${ }^{268}$ This coincided with the beginning of the 1890 economic depression in Australia. ${ }^{269}$ According to historians, the trapping of rabbits helped farmers and stockmen by providing food and extra income, and in some cases helped pay off farming debts during the era of depression in $1890 .{ }^{270}$ The lift of prohibition applied to any person within any city, town, or village in NSW. ${ }^{271}$

By 1919 , due to the proliferation of the wild rabbit industry, ${ }^{272}$ there were labour shortages across all other economic sectors. ${ }^{273}$ According to Eather and Cottle, the Tamworth Pastures Protection Board (NSW) could not find labour to eradicate wild rabbits because all available men were hunting and trapping for the rabbit industries which pushed up costs for all other work such as shearing sheep. ${ }^{274}$ These events coincided with the release of the Rabbit Destruction Ordinance 1919 (NSW), ${ }^{275}$ as part of the Pastures Protection Act 1912 (NSW). However, under section 38 of the Rabbit Destruction Ordinance 1919 (NSW), people who wished to keep domestic rabbits for personal use such as pets, or for use as a source of fur or food could do so with permission from the Minister, ${ }^{276}$ as long as rabbits were kept in a cage or enclosure. ${ }^{277}$ This was a milestone signifying the beginning of an industry of caging rabbits for commercial purposes.

Much later, in 1977, a permit was issued by the NSW state government under the Pastures Protection Act 1934 (NSW) to establish a domestic rabbit farm at Broken Hill (NSW) with the capacity to hold 500,000 rabbits at any one time. ${ }^{278}$ The rabbit farm was not approved due to opposition from the Graziers' Association of NSW. The Graziers' Association argued that farm rabbits would affect the control measures put in place for the eradication of wild rabbits. ${ }^{279}$

Between 1982-1984, the NSW Department of Lands requested an amendment to the Rabbit Destruction Ordinance 1919 (NSW) to allow people to keep a larger number of rabbits (up to 10) for commercial purposes, such as in the pet industry, or as a source of skins or meat subject to keeping the rabbits within cages or enclosures. ${ }^{280}$

In 1990, the Rural Lands Protection Regulation 1990 (NSW) was amended to allow the keeping of a large number $(>100)$ of domesticated rabbits for research purposes; commercial meat or fur production; domestic purposes and rabbits, for public exhibition at a zoo, wildlife park or similar premises. ${ }^{281}$ This change in legislation was followed by an amendment to the Meat Industry Act 1978 (NSW). Under Schedule 1 of the Meat Industry Amendment Act 1998 (NSW), a domestic farmed rabbit became defined as an 'abattoir animal', while section 4(1)(a) defined a wild rabbit as a 'game animal that is not husbanded in the manner of a farmed animal and is killed in the field ... rabbit' ${ }^{282}$ The change in definition under which the domestic rabbit fell under signified a shift in their welfare protection. Within the context of 'abattoir animals', they were now defined as animals purposefully bred for food. This meant that they were no longer protected by the Prevention of Cruelty to Animals Act 1979 (NSW) ${ }^{283}$ but fell under the welfare of the Meat Industry Act 1978 (NSW). More recently, with the introduction of the Food Act 2003 (NSW) and its regulation, the Food Regulation 2015 (NSW), the meat rabbit's welfare in NSW, as an 'abattoir or knackery animal' falls under the animal

\footnotetext{
268 Rabbit Act 1890 (NSW) s 41: 'Nothing in this Act contained shall be construed to prohibit any person in any city, town, or village from keeping live rabbits in any cage or similar enclosure with the permission of the Minister first had and obtained'.

269 Ecologistics, 'Rabbits in Australia' <http://www.ecologistics.com.au/rabbits-in-australia/>.

270 Ibid.

271 Rabbit Act 1890 (NSW), s 41.

272 It was estimated that in late 190616,000 people in NSW were working as rabbit trappers and the industry was worth 1 million Pounds a year. EATHER, W.- COTTLE, D., The Rabbit Industry in South-East Australia, 1870-1970 (Paper presented at the 14th Biennial Labour History Conference, Melbourne 2015)

273 For example, land clearing, farm work, wood carting, potato digging, road repair work, rock splitting (used in road construction) and harvest work; shearers, shed hands, chaff cutters, ploughmen, fencers and council workers. EATHER, W.- COTTLE, D., The Rabbit Industry in South-East Australia, 1870-1970 (Paper presented at the 14th Biennial Labour History Conference, Melbourne, 2015).

274 EATHER, W.- COTTLE, D., The Rabbit Industry in South-East Australia, 1870-1970 (Paper presented at the 14th Biennial Labour History Conference, Melbourne, 2015) 2.

275 An ordinance is a law enacted by a municipal body, such as a city council. Ordinances govern matters not already covered by state or federal laws such as zoning, safety and building regulations. $<$ https://www.lectlaw.com/def2/o045.htm> .

276 Rabbit Destruction Ordinance 1919 (NSW) s 38.'

277 Rabbit Destruction Ordinance 1919 (NSW) s 38.'

278 SOBEY, W.R., Protecting Domestic Rabbits Against Myxomatosis in Australia and the Problems Associated with it Past and Present (Paper presented at Recent Advances in Animal Nutrition, 1981) <http://livestocklibrary.com.au/handle/1234/19383> 279 Ibid.

280 ACT Government, Find of the Month: Canberra 1820-1913

$<$ https://www.archives.act.gov.au/find of the month/2011/february/find of the month $>$.

281 The Rural Lands Protection Regulation 1990 (NSW), r102 'Permission to keep noxious animals noxious animals are specified for the purposes of section 131 (1) of the Act'. The Act being the Rural Lands Protection Act 1989 (NSW).

282 Meat Industry Amendment Act 1998 (NSW) Schedule 1

283 Prevention of Cruelty to Animals Act 1979 (NSW) s2 4(1)(b)(ii).

128 Derecho Animal. Forum of Animal Law Studies, vol. 10/2
} 
welfare protection as defined by the standards of slaughter adopted by the Food Regulation 2015 (NSW). ${ }^{284}$ This aspect of welfare protection of the rabbit will be examined in detail in section 3.3.

\subsubsection{Commercialisation of the Rabbit: Key Legislative Changes in Western Australia}

In the mid-1970s, the classification of rabbits for the Perth metropolitan area changed under section 36 of the Agriculture and Related Resources Protection Act 1976 (WA) (the ARRPA) ${ }^{285}$ to allow for domesticated rabbits to be kept in households and pet shops. The classification of the domestic rabbits under the ARRPA changed from mainly prohibited animals which are subject to eradication to categories which allowed them to be kept subject to conditions and restrictions imposed under the Act. ${ }^{286}$ Under the ARRPA, two rabbits per household were allowed to be kept in cages or enclosures. ${ }^{287}$

Later, in 1984, Western Australia's Agriculture Protection Board (APB), originally established under the Agriculture Protection Board Act 1950 (WA) to assist the agricultural industries to be sustainable by minimising the impact of declared Plants and Animals, ${ }^{288}$ recommended changes to regulations on keeping rabbits both as pets and for commercial purposes. This was granted under sections 35 and 36 of the Agriculture and Related Resources Protection Act 1976 (WA) ${ }^{289}$ The following breeds of rabbits were reclassified for commercialisation: New Zealand White, Californians, Flemish Giant, Chinchilla, Satins, English Angora, French Angora and German Angora. ${ }^{290}$

Western Australia became the first state to lift the ban on commercial farming of rabbits between 19851987, by approving the keeping of domestic type rabbits within enclosures or cages. Under regulation 16(2) of the Agriculture and Related Resources Protection (Declared Animals) Regulations 1985 (WA), ${ }^{291}$ the APB approved, subject to a licence, the secure keeping of commercial domestic rabbit breeds with a specification of minimum 200 breeding does (female rabbits) in accordance with a good husbandry practice. ${ }^{292}$ In 1987 the first intensive rabbit meat farm in Australia was established in WA (Baldivis) ${ }^{293}$ and will be subject to animal welfare analysis in Chapter Four.

In summary, up until 1987, there was a complete ban on domestic rabbit farming in Australia. In 1987, Western Australia amended its legislation to lift that ban. New South Wales and Victoria followed suit in 1995 and 1997 respectively, and soon all states were farming rabbits except for Queensland. ${ }^{294}$ Before the bans were lifted, 2.7 million rabbits a year were estimated to have been hunted in Australia in the wild up until the early 1990s. ${ }^{295}$ The shift to domestic intensive farming is reflected in the slow changes of legislation introducing permits for the control and confinement of domestic rabbits within enclosures and cages, all while amending meat Acts to include domesticated farmed rabbits as abattoir animals. Within the same time frame (1987-1991), the creation of codes of practice for husbandry of rabbits in intensive farms had begun and the development of the Commonwealth research program in the intensive rabbit meat industry, Crusader, commenced to support the caged rabbit meat industry. ${ }^{296}$

\section{PART TWO: Analysis}

284 Clause 83 and clause 89 of the Food Regulation 2015 (NSW).

285 An Act to 'provide for the management, control and prevention of certain plants and animals, for the prohibition and regulation of the introduction and spread of certain plants and of the introduction, spread and keeping of certain animals, for the protection of agriculture'.

286 Agriculture and Related Resources Protection Act 1976 (WA) s 36 (4) 'category A1 in respect of an area are prohibited; category A2 in respect of an area if those animals (i) are not vertebrate animals native to that area; and should be eradicated in that area; category A3 in respect of an area if the keeping of those animals are prohibited; category A4 in respect of an area if the introduction of those animals into that area should be subject to conditions and restrictions imposed by or under the regulations; category A6 in respect of an area if the keeping of those animals in that area should, be subject to conditions and restrictions imposed by or under the regulations'. 287 Western Australian Government, 'Gazette 30_05_1986'

$<$ https://www.slp.wa.gov.au/gazette/gazette.nsf/searchgazette/8175B56388EEF36BC825734B0020E564/\$file/gg059.pdf>.

288 Agriculture Protection Board of Western Australia, Annual Report To 18 December 2010 (2010).

289 Western Australia, Agriculture and Related Resources Protection Act 1976, Gazette 59,30 May 1986,1818.

290 Western Australia, Agriculture and Related Resources Protection Act 1976,Gazette 113, 27 November 1987,4313.

291 Under the Agriculture and Related Resources Protection Act 1976 (WA)

292 GRAY, G., Historical perspective of the legalisation of keeping pet rabbits in Western Australia, Vertebrate Pest Research Services (online) $<$ http://members.iinet.net.au/ rabbit/waprhist.htm>.

293 FOSTER, M., Emerging animal and plant industries: their value to Australia (2009) 14/069 Rural Industries Research and Development Corporation, $42<\mathrm{https}$ ://rirdc.infoservices.com.au/downloads/14-069>

294 EADY, S., Farmed Rabbits in Australia (2003) 02/144 Rural Industries Research and Development Corporation $<$ https://rirdc.infoservices.com.au/downloads/02-144>

295 FOSTER, M., Australian Farmed Rabbit: Prospects for Industry Development (1999) 99/89 Rural Industries Research and Development Corporation, <https://rirdc.infoservices.com.au/downloads/99-089>

296 EADY, S., Farmed Rabbits in Australia (2003) 02/144 Rural Industries Research and Development Corporation, 1-46. 


\subsection{An Analysis of Regulatory Instruments Regulating Domestic Rabbit Industries}

To set the scene for the analysis of domestic rabbit industry regulation, it is relevant to note that the protection afforded to the domestic rabbit has been criticised by several authors. ${ }^{297}$ For example, as an internationally recognised animal welfare scientist, Broom highlights the inconsistencies in the treatment and animal welfare protection of rabbits under different human uses in the United Kingdom which he says are scientifically unsound and contradictory. This raises the possibility that these disparities also exist in Australia. Broom says:

'A rabbit is viewed differently according to whether it is a family pet, a laboratory animal, an animal kept for meat production, or a wild animal that eats your crops. This is not scientifically sound as the biological functioning of the rabbit varies little with human usage. Each individual rabbit, once past a certain level of development, has its own perceptions of the world around it, an ability to feel pain, a degree of cognitive function, an array of coping mechanisms and a consequence for its welfare when there is an environmental impact on it. Should we not consider the welfare of the individual rabbit first and our usage of it second. ${ }^{298}$

In this section, I investigate the statutes used to regulate specific domestic rabbit industries and their relationship to the animal welfare Acts. It is the section's aim to identify what protection framework the rabbits fall under and identify any issues where rabbits fall outside animal welfare protection.

O'Sullivan categorises animals according to whether they are of economic use or not. ${ }^{299}$ According to that categorisation, the rabbit as a captive species can be subdivided into two subgroups: as a noneconomically productive animal, such as a companion animal, whose value is emotional to humans, ${ }^{300}$ or an economically productive animal seen as a production unit. ${ }^{301}$ Rabbits falling under the economically productive animal group in this section are those in which domestic rabbits are most commonly used and caged or bred within cages: the meat, research, and pet industries.

Historically intensive rabbit meat farms in Australia have supplied both meat and fur. ${ }^{302}$ It is therefore assumed in this thesis that the fur/pelt rabbit industry is regulated under the same animal welfare regime as the rabbit meat industry. Furthermore, the research is confined to three States; Victoria (Vic), New South Wales (NSW) and Western Australia (WA).

The section is divided into two subsections as follows:

3.3.2 As rabbits are defined by veterinary science to be mammals, ${ }^{303} \mathrm{I}$ identify whether the definition of 'animal' within the relevant animal welfare Acts includes 'mammals'. Identifying rabbits as mammals is important as it indicates their sentience which attaches moral standing to them illustrating that they can be harmed and that they do suffer, and therefore need protection.

For each of the selected economic uses of the rabbit, I identify the category the rabbit sits under within that statute or regulatory instruments, for example 'abattoir animal', 'stock animal' or 'research animal'. The definition of the rabbit reflects their use and will subsequently drive the animal welfare provisions that protects them.

3.3.3 I identify the relationship between regulatory statutes that provide for the use of the rabbit under specific industries and the relationship of the statutes to the animal welfare Acts.

It has been argued that animals used in an economic context, such as food or research animals, can be excluded from animal welfare Acts. ${ }^{304}$ Those exclusions are investigated under the different economic uses of the domestic rabbit as defined at the start of this chapter.

Analysis of the legislation as referenced within this section can be found in the Appendices as follows;

297 BROOM, D.M., Cognitive ability and awareness in domestic animals and decisions about obligations to animals (2010) 126(1) Applied Animal Behaviour Science; FAVRE, D., The Degree of Legal Regulation, in Mike Radford (ed), Animal welfare law in Britain (Oxford University Press, 2001) 123.

298 BROOM, D.M., Cognitive ability and awareness in domestic animals and decisions about obligations to animals (2010) 126(1) Applied Animal Behaviour Science.

299 O’SULLIVAN, S., Animals, Equality and Democracy (Palgrave MacMillan, 2011) 29.

300 Ibid.

301 Ibid.

302 TWOMEY, S., Akubra dumps Australian rabbit suppliers for Russian rabbit skins, The Weekly Times (online) 8 July 2015 $<$ https://www.weeklytimesnow.com.au/agribusiness/sheep/akubra-dumps-australian-rabbit-suppliers-for-russian-rabbit-skins/newsstory/c28e7fcf4e32d8acdcfa27f8f47c5768; accessed>.

303 Merck Sharp \& Dohme Corporation Veterinary Manual, Description and Physical Characteristics of Rabbits $<$ https://www.msdvetmanual.com/all-other-pets/rabbits/description-and-physical-characteristics-of-rabbits>.

304 BRUCE, A., Animal Law in Australia: An Integrated Approach (LexisNexis Butterworths, 2nd ed, 2017) 209.

130 Derecho Animal. Forum of Animal Law Studies, vol. 10/2 
NSW [Appendices 2A-2C], Vic [Appendices 2D-2F], WA [Appendices 2G-2I].

\subsubsection{Definition of Rabbits under Welfare Acts and Legislation}

Each State and Territory prohibits cruelty to an 'animal' through their animal welfare Acts. ${ }^{305}$ Table 2 identifies which category of 'animal' a rabbit might be defined under within those animal welfare Acts for the jurisdictions defined within this thesis.

\begin{tabular}{|l|l|l|l|}
\hline Jurisdiction & NSW & Vic & WA \\
\hline Animal Welfare Act & $\begin{array}{l}\text { Prevention of Cruelty to } \\
\text { Animals Act 1979 (NSW) } \\
\text { s4(1) }\end{array}$ & $\begin{array}{l}\text { Prevention of Cruelty to } \\
\text { Animals Act 1986 (Vic) } \\
\text { s3(3) }\end{array}$ & $\begin{array}{l}\text { Animal Welfare Act 2002 } \\
\text { (WA) s5(1) }\end{array}$ \\
\hline $\begin{array}{l}\text { Definition of 'Animal' a } \\
\text { rabbit falls under }\end{array}$ & Mammal & Mammal & Vertebrate \\
\hline
\end{tabular}

Table (2) Definition of 'animal' under which a rabbit sits

A. Rabbits with a non-economic value:

As a non-economically productive animal such a companion animal, the rabbit falls under the general provisions of the animal welfare Acts within NSW, ${ }^{306} \mathrm{Vic}^{307}$ and $\mathrm{WA},{ }^{308}$ under the definitions listed in Table 2.

The rabbit is not specifically defined as a companion animal under any of the domestic or companion statutes in $\mathrm{NSW}^{309}$ or Vic ${ }^{310}$ while in WA there is no general companion or domestic animal Act. The exclusion of the rabbit from any companion Act despite the growth in popularity of rabbits as companion animals ${ }^{311}$ could be a direct result of this species falling into both the economic and noneconomic niches creating a grey area that cannot be categorized.

B. Rabbits with an economic value:

An agricultural rabbit within the meat and fur industry framework, falls within the meaning of 'stock animal' in NSW under the Prevention of Cruelty to Animals Act 1979 (NSW), ${ }^{312}$ or an 'abattoir animal: rabbit' under the Food Regulation 2015 (NSW). ${ }^{313}$ In Victoria, under the Prevention of Cruelty to Animals Act 1986 (Vic) a rabbit falls under the general definition 'mammal other than human' ${ }^{314}$ Under the Prevention of Cruelty to Animals Act 1986 (Vic) the rabbit does not fall under the definition of farm animal, however is exempted as a food animal by the act of 'slaughtering, 315 from the Act as will be seen in section 3.3.2. Rabbits are a 'consumable animal' under the Meat Industry Act 1993 (Vic) $)^{316}$ and a 'prescribed consumable animal: Rabbit if not living in the wild' under the Meat Industry Regulations 2015 (Vic). ${ }^{317}$ In Western Australia, a meat rabbit falls under the definition 'animal which does not include a fish, crustacean or mollusc' under the Food Regulations 2009 (WA). ${ }^{318}$

In NSW, rabbits used in scientific research are defined under the Animal Research Act 1985 (NSW) as

305 Animal Welfare Act 1992 (ACT); Prevention of Cruelty to Animals Act 1979 (NSW); Animal Welfare Act 1999 (NT); Animal Care and Protection Act 2001 (Qld); Prevention of Cruelty to Animals Act 1985 (SA); Animal Welfare Act 1993 (Tas); Prevention of Cruelty to Animals Act 1986 (Vic); Animal Welfare Act 2002 (WA).

306 Prevention of Cruelty to Animals Act 1979 (NSW)

307 Prevention of Cruelty to Animals Act 1986 (Vic)

308 Animal Welfare Act 2002 (WA)

309The rabbit falls under the definition of 'any other animal that is prescribed by the regulations as a companion animal' under section 5 of Companion Animal Act 1998 (NSW) s5.

310 A rabbit is a 'prescribed animal' under the Domestic Animals Regulations 2015 (Vic) r5.

311 According to Animal Medicines Australia the rabbit is the fifth most popular companion animal in Australia. Animal Medicines Australia, Pet Ownership in Australia $2016(2016)<\mathrm{http} / / /$ animalmedicinesaustralia.org.au/wp-content/uploads/2016/11/AMA_PetOwnership-in-Australia-2016-Report_sml.pdf>, 10.

312 Prevention of Cruelty to Animals Act 1979 (NSW) s 4 Stock animal: 'which means an animal which belongs to the class of animals comprising cattle, horses, sheep, goats, deer, pigs, poultry and any other species of animal prescribed for the purposes of this definition'.

313 Food Regulation 2015 (NSW) s 76(1).

314 Prevention of Cruelty to Animals Act 1986 (Vic) s 3(a).

315 Ibid s 6(1)a.

316 Meat Industry Act 1993 (Vic) s 3(d)

317Meat Industry Regulations 2015 (Vic) s 6(g).

318 Food Regulations 2009 (WA)r 17 
'a vertebrate animal, including a mammal that is not a human being. ${ }^{319}$ In Victoria, rabbits used for scientific procedures are defined under the Prevention of Cruelty to Animals Act 1986 (Vic) as a 'specified animal: rabbit' ${ }^{320}$ In WA, under the Animal Welfare Act 2002 (WA), a rabbit used in research falls under the definition of 'live vertebrate' and a 'laboratory animal' under the Animal Resources Authority Act 1981 (WA) who are the authority for supplying laboratory animals for teaching and research purposes. ${ }^{321}$

The rabbit's life is set by their definition in a particular human use setting. The animal welfare protection of rabbits under different uses can make them more vulnerable to cruel treatment as a result of financial gains. ${ }^{322} \mathrm{O}$ 'Sullivan describes the different categorisations of the rabbit as:

'A rabbit is a 'something' rabbit and that something is very important when it comes to the level of protection the rabbit receives against harm'. ${ }^{323}$

The discrimination in the standards of legal protection that follows from the initial classification of an animal as a result of their human use, according to McEwan, 'humanises' companion animals and removes the view of sentience applied to economic animals by treating them as economic units, ${ }^{324}$ such as categorising rabbits as 'prescribed animal', 'stock animal' and 'consumable animal'. The implication of sentient animals that comes with some definitions such as companion animals attaches intrinsic value to animals and gives them moral worth which would follow that it is wrong for humans to inflict unnecessary suffering on them. However, reducing rabbits to economic units legitimises humans to inflict 'necessary' suffering on animals if a substantial benefit to humans is likely to occur such as in the industries of food and research. ${ }^{325}$

The next section explores the effects of the various definitions of the rabbit species in relation to the animal welfare Act, i.e. whether rabbits are excluded directly or indirectly from animal welfare Acts depending on their uses, to understand their level of protection by the law.

\subsubsection{Direct \& Indirect Exemptions of the Domestic Rabbit from Animal Welfare Acts}

Following on from section 3.3.1, where rabbits were explicitly identified under different categories reflecting human economic purposes, the objective of this subsection is to identify the relationship between the regulatory statutes under which the rabbits fall for economic purposes and the relationship of the statutes to the animal welfare Acts. The analysis aims to investigate how the domestic rabbit under specific industries is regulated.

Each statute covering an industry where the rabbit is used will either have a reference to protective legislation, or where there is no mention, the default position is that the relevant animal welfare act will apply unless the animal is excluded from that Act through a series of defences or exemptions to prosecutions for animal cruelty offences. ${ }^{326}$

According to Bruce, whole categories of animals, such as those used for food or research, i.e. those of economic value to humans, are largely exempted from animal welfare Acts. ${ }^{327}$ Bruce divides the exemptions under which animals are used to benefit humans as either direct exemptions or indirect exemptions. ${ }^{328}$ Direct exemptions are those that exempt a species or group of animals such as animals used for food and scientific experimentation from the animal welfare Act, ${ }^{329}$ while indirect exemptions are those that exempt specific conduct using a Code of Practice. ${ }^{330}$

Provisions within the animal welfare Acts allow some forms of conduct towards animals under specified Model Codes of Practice or State and Territory specific Codes of Practice or the (NHMRC) Australian Code for the Care and Use of Animals for Scientific Purposes 8th edition (2013) $)^{331}$ (in this section, the Research Code) which would otherwise not be allowed under the animal welfare Acts. ${ }^{332}$

319 Animal Research Act 1985 (NSW) s 3

320 Prevention of Cruelty to Animals Act 1986 (Vic) s 25

321 Animal Resources Authority Act 1981 (WA) s 3 'laboratory animal means an animal used for teaching, research, or diagnostic purposes or for any purpose incidental thereto'

322 O’SULliVAN, S., Animals, Equality and Democracy (Palgrave MacMillan, 2011) 166.

323 Ibid 31.

324 McEWAN, A.B., The Concept of Violence: A Proposed Framework for the Study of Animal Protection Law and Policy (PhD Thesis, The Australian National University, 2016) 134.

325 GARNER, R., Animals, Ethics and Public Policy (2010) 81 The Political Quarterly, 126.

326 BRUCE, A., Animal Law in Australia: An Integrated Approach (LexisNexis Butterworths, 2nd ed, 2018). 208.

327 Ibid 209.

328 Ibid.

329 Ibid 202.

330 Ibid 209.

331 National Health and Medical Research Council, Australian Code of Practice of the Care and Use of Animals for Scientific Purposes 8th Edition 2013 (National Health and Medical Research Council, 8th ed, 2013).

332 BRUCE, A., Animal Law in Australia: An Integrated Approach (LexisNexis Butterworths, 2nd ed, 2018) 210.

132 Derecho Animal. Forum of Animal Law Studies, vol. 10/2 
The Model Codes of Practice for the Welfare of Animals (MCOP) have been discussed in Chapter Two. The legal status of the MCOP depends on whether the relevant state or territory adopts the MCOP. ${ }^{333}$ As a summary, there are three possible circumstances that arise in this context:

Firstly, a MCOP will be mandatory if it is adopted and the regulation indicates that compliance with the MCOP is mandatory;

Secondly if part of the MCOP is adopted some parts of MCOP are made compulsory by adopting them into a regulation;

Thirdly other 'adopted' MCOP are not compulsory and are used for standards of animal husbandry or management, and some MCOP are neither compulsory nor adopted which gives them no legal status. ${ }^{334}$ With regards to the compliance with MCOP in NSW, the Prevention of Cruelty to Animals Act 1979 (NSW) provides compliance or failure to comply with the MCOP is admissible as evidence or as a defence to a charge of animal cruelty. ${ }^{335} \mathrm{In} \mathrm{Vic}{ }^{336}$ and $\mathrm{WA},{ }^{337}$ the MCOP are relied upon as a defence to prove that a person was acting in accordance with the code. ${ }^{338}$

Table 3 lists the MCOP and State specific Codes of Practice applicable to domestic rabbit in the meat (and fur), research and pet industries. It also identifies their legal status in NSW, Vic and WA.

\begin{tabular}{|c|c|c|c|}
\hline $\begin{array}{l}\text { Codes of Practice for the Welfare of Animals [as applied to } \\
\text { Domestic Rabbits] }\end{array}$ & NSW & Vic & WA \\
\hline \multicolumn{4}{|l|}{ Industry: Intensive (Meat, Fur, Pet breeding) } \\
\hline $\begin{array}{l}\text { The Model code of Practice for the Welfare of Animals: Intensive } \\
\text { Husbandry of Rabbits }\end{array}$ & $\begin{array}{l}\text { Used as } \\
\text { Evidence } \\
339\end{array}$ & - & - \\
\hline Code of Practice for Keeping of Rabbits in WA & - & - & $\begin{array}{l}\text { adopted as } \\
\text { Defence } \\
340\end{array}$ \\
\hline Code of Practice for the Intensive Husbandry of Rabbits Vic & - & $\begin{array}{c}\text { Used as } \\
\text { Defence }{ }^{341}\end{array}$ & - \\
\hline \multicolumn{4}{|l|}{ Industry: Scientific Research } \\
\hline $\begin{array}{l}\text { Australian Code of Practice for the Care and Use of Animals for } \\
\text { Scientific Purposes [8th edition (2013)] }\end{array}$ & Adopted $^{342}$ & Adopted $^{343}$ & Adopted $^{344}$ \\
\hline $\begin{array}{l}\text { Code of Practice for the Housing and Care of Laboratory Mice, } \\
\text { Rats, Guinea Pigs and Rabbits }\end{array}$ & - & Adopted $^{345}$ & - \\
\hline $\begin{array}{l}\text { Code of Practice for the Use of Animals from Municipal Pounds } \\
\text { in Scientific Procedures }\end{array}$ & - & Adopted $^{346}$ & - \\
\hline \multicolumn{4}{|l|}{ Industry: Pet/companion } \\
\hline Code of Practice for the Operation of Pet Shops & - & adopted $^{347}$ & - \\
\hline Animal Welfare Code of Practice_-Animals in Pet Shops & adopted $^{348}$ & - & - \\
\hline
\end{tabular}

333 Ibid 81.

334 Ibid.

335 Prevention of Cruelty to Animals Act 1979 (NSW) s34A(3) 'Compliance, or failure to comply, with any guidelines prescribed or adopted by the regulations for the purposes of subsection (1) is admissible in evidence in proceedings under this Act of compliance, or failure to comply, with this Act or the regulations'.

336 Prevention of Cruelty to Animals Act 1986 (Vic) s6(1)(b) 'except to the extent that it is necessary to rely upon a Code of Practice as a defence'.

337 Animal Welfare Act 2002 (WA) part 3 s25 'It is a defence to a charge under section 19(1) for a person to prove that the person was acting in accordance with a relevant code of practice'.

338 BRUCE, A., Animal Law in Australia: An Integrated Approach (LexisNexis Butterworths, 2nd ed, 2018) 208.

339 Prevention of Cruelty to Animals Act 1979 (NSW) s 34A(3).

340 Animal Welfare Act 2002 (WA) s. 25; Animal Welfare Act 2002 (WA) s 94(2)(d); Animal Welfare Regulation 2003 (WA) r 6

341 Prevention of Cruelty to Animals Act 1986 (Vic) s 6(1)b.

342 Research Act 1985 (NSW) s 4

343 Prevention of Cruelty to Animals Act 1986 (Vic) s 7 and Part3

344 Animal welfare act 2002 (WA) s 94(2)(d) and part 2

345 Prevention of Cruelty to Animals Act 1986 (Vic) s 32; Prevention of Cruelty to Animals Regulation 2008 (Vic) r 92

346 Ibid

347 Adopted under section 59 of the Domestic Animals Act 1994 (Vic) - see notice of the making of which was published in Government Gazette No. G13 on 4 April 1996, page 847.

348 Prevention of cruelty to animals regulations 2012 (NSW) schedule 1. 
Animal Welfare Code of Practice No 1-Companion Animal Transport Agencies

$\operatorname{adopted}^{349}$

anted

Table (3) Application of Model Codes of Practice for the Welfare of Animals within the Domestic Rabbit Industries: meat (fur), research and companion animals

\subsubsection{Rabbits used for food}

\section{New South Wales}

Rabbits farmed for food in NSW are directly excluded from the operation of the Prevention of Cruelty to Animals Act 1979 (NSW) through their exemptions from specific provisions such as the need to exercise. . $^{350}$ Rabbits as food animals in NSW fall under the definition of 'stock animal' ${ }^{351}$ or 'an animal of a species which is usually kept in captivity by means of a cage ${ }^{352}$ under the Prevention of Cruelty to Animals Act 1979 (NSW). ${ }^{353}$ While the provision under section 9 of the Prevention of Cruelty to Animals Act 1979 (NSW) states that a person in charge of a confined animal should not fail to provide them with adequate exercise, ${ }^{354}$ the provision under section 9(1A) excludes the duty of providing adequate exercise if the animal is defined as a 'stock animal' or is usually kept in captivity by means of a cage. ${ }^{355}$

The Model code of Practice for the Welfare of Animals: Intensive Husbandry of Rabbits ${ }^{356}$ (MCOPIHR) is the Commonwealth Model code of Practice for animal welfare in the intensive husbandry of domestic rabbits for commercial production. ${ }^{357}$ Industries which fall under intensive farming are assumed in this analysis to include meat and fur industries, as historically intensive rabbit meat farms in Australia have supplied both meat and fur. ${ }^{358}$ The Department of Primary Industries recommends prospective farmers use the MCOPIHR as a guide to minimum animal welfare standards in intensive farming. ${ }^{359}$ The objective of the MCOPIHR is to provide a minimum set of guidelines for the care and management of farmed rabbits. ${ }^{360}$ The provisions of animal welfare within the MCOPIHR are examined in detail in Chapter Four.

As shown in Table 3, the MCOPIHR is a voluntary code in NSW as it is not made legal by adopting it within the law, nor is it a specified condition of any licence. It is therefore not an offence if the minimum standards of animal care as specified within the MCOPIHR are not complied with. However, in case of a charge of animal cruelty offence, according to Table 3, compliance with the MCOPIHR can be used as evidence to show that the 'alleged act of cruelty' is standard farming practice and is 'necessary'. In this way, compliance with the MCOPIHR indirectly excludes rabbits from the Prevention of Cruelty to Animals Act 1979 (NSW).

Rabbits killed for food are also excluded from the Prevention of Cruelty to Animals Act 1979 (NSW) in the case of slaughter. Under section 24(1)(b)(ii) of the Prevention of Cruelty to Animals Act 1979 (NSW), it is not an offence for a person to undertake the act of 'destroying the animal, or preparing the animal for destruction, for the purpose of producing food for human consumption, in a manner that inflicted no unnecessary pain upon the animal'. In NSW, the slaughter of rabbits for human consumption is dealt with in legislation concerned with meat production and safety. Under the Food Act 2003 (NSW), the Food Regulation

\section{Ibid.}

350 Section 9(1A) of the Prevention of Cruelty to Animals Act 1979 (NSW).

351 Prevention of Cruelty to Animals Act 1979 (NSW) s 4 Stock animal: "which means an animal which belongs to the class of animals comprising cattle, horses, sheep, goats, deer, pigs, poultry and any other species of animal prescribed for the purposes of this definition'.

352 Prevention of Cruelty to Animals Act 1979 (NSW) s9(1A)(b).

353 Prevention of Cruelty to Animals Act 1979 (NSW) s 4 'Stock animal: 'which means an animal which belongs to the class of animals comprising cattle, horses, sheep, goats, deer, pigs, poultry and any other species of animal prescribed for the purposes of this definition'.

354 Section 9 of the Prevention of Cruelty to Animals Act 1979 (NSW)

355 Section 9(1A) of the Prevention of Cruelty to Animals Act 1979 (NSW).

356 CSIRO Publishing and Primary Industry Standing Committee (Cth), Model Code of Practice for the Welfare of Animals: Intensive Husbandry of Rabbits (Primary Industries Report Series 33, 2003).

357 CSIRO Publishing and Primary Industry Standing Committee (Cth), Model Code of Practice for the Welfare of Animals: Intensive Husbandry of Rabbits (Primary Industries Report Series 33, 2003), 1.

358 TWOMEY, S., Akubra dumps Australian rabbit suppliers for Russian rabbit skins, The Weekly Times (online) 8 July 2015 $<$ https://www.weeklytimesnow.com.au/agribusiness/sheep/akubra-dumps-australian-rabbit-suppliers-for-russian-rabbit-skins/newsstory/c28e7fcf4e32d8acdcfa27f8f47c5768;accessed>.

359 NSW Department of Primary Industries, National Model Codes of Practice for the Welfare of Livestock $<$ http://www.dpi.nsw.gov.au/animals-and-livestock/animal-welfare/general/national $>$.

360 CSIRO Publishing and Primary Industry Standing Committee (Cth), Model Code of Practice for the Welfare of Animals: Intensive Husbandry of Rabbits (Primary Industries Report Series 33, 2003). 
2015 (NSW) defines the rabbit as an 'abattoir animal' if prepared for human consumption and a 'knackery animal' if prepared for the 'pet' food industry. ${ }^{361}$ Therefore the rabbit used for food purposes falls under the protection of the Food Act 2003 (NSW) which adopts under its regulation Food Regulation 2015 (NSW) two standards of slaughter; the Australian Standard for Hygienic Production of Rabbit Meat for Human Consumption (AS 4466-1998) (362 $^{36}$ and the Australian Standard for the Hygienic Production of Meat and Meat Products for Human Consumption (AS 4696:2007). ${ }^{363}$ Table 4 lists how the standards of slaughter have been adopted in NSW, Vic and WA.

\begin{tabular}{|l|l|l|l|}
\hline Standard & NSW & VIC & WA \\
\hline AS 4466:1997 & - & $\begin{array}{l}\text { Under Meat Act 1993 } \\
\text { (Vic) through a licence } \\
\text { condition with PrimeSafe }\end{array}$ & $\begin{array}{l}\text { Food Regulations 2009 (WA)/ } \\
\text { does not specify which version } \\
1997 \text { or 1998 }\end{array}$ \\
\hline AS 4466:1998 & $\begin{array}{l}\text { Adopted Under Food } \\
\text { Regulation 2015 (NSW) }\end{array}$ & - & - \\
\hline AS 4696:2007 & $\begin{array}{l}\text { Standard 17 of Part 6 } \\
\text { adopted only } \\
\text { [Food Regulation 2015 } \\
\text { (NSW) r83(3)] }\end{array}$ & $\begin{array}{l}\text { Standard 25 (Transport) } \\
\text { adopted under Meat } \\
\text { Industry Regulations } \\
\text { 2015 (Vic) }\end{array}$ & $\begin{array}{l}\text { Adopted under Food Regulations } \\
\text { 2009 (WA) }\end{array}$ \\
\hline
\end{tabular}

Table (4) Adoption of Slaughter Standards in NSW, Vic and WA

Rabbits slaughtered for human consumption in NSW fall within the animal welfare standards as set out in AS 4466-1998. ${ }^{364}$ AS 4466-1998 states that ' $[\mathrm{t}$ ] he Operation under this standard implies compliance with relevant Model Codes of Practice for the welfare of animals', ${ }^{365}$ which in NSW is the MCOPIHR. Section 7 of AS 4696:2007, which lists the animal welfare standards on slaughter and handling, is not adopted in NSW, as can be seen in Table 4. The animal welfare clauses within the standards are listed in Table 5.

With respect to auditing under the AS 4466-1998, the inspector is appointed by a controlling authority or by the registered company and approved by the controlling authority and is defined in Table $5 .{ }^{366}$ The auditing inspector as defined by AS 4466:1998 in Table 5 is responsible for enforcing meat hygiene and not animal welfare.

\begin{tabular}{|c|c|c|}
\hline Standard & References to Animal Welfare & Auditors \\
\hline AS 4466:1997 & $\begin{array}{l}\text { Scope: Operation under this standard } \\
\text { implies compliance with relevant Model } \\
\text { Codes of Practice for the Welfare of } \\
\text { Animals } \\
\text { Standard } 10 \text { ante mortem inspection: } \\
\text { - Animals handled in humane way and } \\
\text { rested } \\
\text { - Supply of drinking water } \\
\text { Standard 11: Processing Procedures: } \\
\text { - Rabbits rested before slaughter } \\
\text { - Transported in clean cages } \\
\text { - Restrained by approved method } \\
\text { - Stunned by approved humane method } \\
\text { prior to bleeding }\end{array}$ & $\begin{array}{l}\text { Inspector: a person appointed by the controlling } \\
\text { authority or appointed by the registered company } \\
\text { and approved by the controlling authority** for the } \\
\text { purpose of auditing quality assurance systems or } \\
\text { antemortem and post-mortem inspection and control } \\
\text { of hygiene in a processing premises. } \\
\text { ** Controlling authority defined as a person or body } \\
\text { that under a law of a State, Territory or the } \\
\text { Commonwealth has statutory responsibility for meat } \\
\text { hygiene }\end{array}$ \\
\hline AS 4466:1998 & See $4466: 1997$ sections 10 and 11 & See AS 4466:1997 \\
\hline
\end{tabular}

361 Food Regulation 2015 (NSW) r76

362 Australian Standard for Hygienic Production of Rabbit Meat for Human Consumption, SCARM Report 59, AS 4466:1997.

363 Australian Standard for the Hygienic Production of Meat and Meat Products for Human Consumption, FRSC Technical Report No. 3, AS 4696: 2007, 21.

364 Standards 10 and 11 in the Australian Standard for Hygienic Production of Rabbit Meat for Human Consumption, SCARM Report 59, AS 4466:1998.

365 Australian Standard for Hygienic Production of Rabbit Meat for Human Consumption, SCARM Report 59, AS 4466:1998, 1.

366 The Controlling authority is defined as a person or body that under a law of a State, Territory or the Commonwealth has statutory responsibility for meat hygiene 


\begin{tabular}{|c|c|c|}
\hline AS 4696:2007 & $\begin{array}{l}\text { Standard 7, 'animal welfare': } \\
\text { 'minimisation of the risk of injury pain and } \\
\text { suffering and the least practical disturbance } \\
\text { to animals } \\
\text { Includes } \\
\text { - Handling } \\
\text { - slaughter }\end{array}$ & $\begin{array}{l}\text { Meat Safety Inspector: } \\
\text { An individual who is given approval by the } \\
\text { controlling authority** to inspect animals, meat and } \\
\text { meat products and to apply dispositions and holds } \\
\text { qualifications that are approved by the controlling } \\
\text { authority as being qualifications required for the } \\
\text { purpose of the inspection of animals, meat and meat } \\
\text { products, the making and dispositions and the } \\
\text { control of hygiene. } \\
* * \text { Controlling authority when used in relation to the } \\
\text { production of meat or meat products means the Cth, } \\
\text { state or territory authority that is responsible for the } \\
\text { enforcement of this standard as it applies to the meat } \\
\text { or meat products }\end{array}$ \\
\hline
\end{tabular}

Table (5) Animal welfare provisions and auditing under standards of slaughter applied within the rabbit food industry

In summary, rabbits raised for meat in NSW are excluded from animal welfare provisions within the Prevention of Cruelty to Animals Act 1979 (NSW). Instead, they fall under the Food Act 2003 (NSW) which does not define standards of humane slaughter or stunning.

\section{Victoria}

In Victoria, rabbits used for food fall by default under the protection of the Prevention of Cruelty to Animals Act 1986 (Vic) during the first part of their life, that is while they are alive on farms. At the point of slaughter, rabbits will be directly exempted from the Prevention of Cruelty to Animals Act 1986 (Vic) ${ }^{367}$ and slaughtered in accordance with the Meat Industry Act 1993 (Vic). ${ }^{368}$ Rabbits under the Meat Industry Act 1993 (Vic) fall under the definition of 'consumable animal'. ${ }^{369}$

The Code of Practice for the Intensive Husbandry of Rabbits Vic ${ }^{370}$ which is the Victorian State-based husbandry code for intensive farming of domestic rabbits was 'approved for preparation' under section 7 of the Prevention of Cruelty to Animals Act 1986 (Vic) as listed within the Government Gazette in 1997. ${ }^{371}$ It is based on the minimum standards of animal welfare as per the MCOPIHR with some additional provisions for the management of rabbits such as vaccinations against the Calici Virus. ${ }^{372}$ In 2004, the MCOPIHR was adopted as a whole document within the Prevention of Cruelty to Animals (further amendment) Regulation 2004 (Vic) under section 7 of the Prevention of Cruelty to Animals Act 1986 (Vic), however in 2008, the Prevention of Cruelty to Animals Regulation 2008 (Vic) revoked the MCOPIHR, leaving the state based code for use as a defence to a charge of animal cruelty. ${ }^{373}$ It is therefore not a mandatory Code.

There are no references to animal welfare under either the Meat Act 1993 (Vic) or the Meat Industry Regulations 2015 (Vic). The slaughtering Standard, the Australian Standard for the Hygienic Production and Transportation of Meat and Meat Products for Human Consumption (AS 4696:2007), is adopted in part under the Prevention of Cruelty to Animals Regulation 2008 (Vic) to regulate meat transport vehicles and equipment. ${ }^{374}$ However, under the Meat Industry Act 1993 (Vic), an abattoir is unable to commence operations until a licence has been granted by an Authority, in this case PrimeSafe, an entity established under the Meat Industry Act 1993 (Vic). ${ }^{375}$ PrimeSafe licence conditions require abattoirs to comply with relevant Australian and Victorian standards and guidelines. ${ }^{376}$ This includes the Australian Standard for Hygienic Production of Rabbit Meat for Human Consumption (AS 4466:1997) which includes the only reference to animal welfare as applied to rabbits in abattoirs as indicated in Table 5.

\section{Western Australia}

367 Prevention of Cruelty to Animals Act 1986 (Vic) s 6(1)(a).

368 Ibid.

369 Meat Industry Act 1993 (Vic) s 3.

370 Department of Agriculture (Vic), Code of Practice for the Intensive Husbandry of Rabbits (State of Victoria).

371 Victoria, Prevention of Cruelty to Animals Act 1986 Preparation of Code of Practice, Gazette 50, 18 December $1997,3728$.

372 Department of Agriculture (Vic), Code of Practice for the Intensive Husbandry of Rabbits (State of Victoria).

373 Prevention of Cruelty to Animals Act 1986 (Vic) s6(1)b

374 Meat Industry Regulations 2015 (Vic),regulations 19(1), 20(2), 22, 23(2)(d), 24(1) and 33(2)(f)

375 Meat Act 1993 (Vic) s 43

376 PrimeSafe, Standards and Guidelines $<$ http://www.primesafe.vic.gov.au/standards-and-guidelines/>.

136 Derecho Animal. Forum of Animal Law Studies, vol. 10/2 
Under the Animal Welfare Act 2002 (WA), accepted husbandry practices used in farming provide a defence for a charge of animal cruelty. ${ }^{377}$ The Code of practice for keeping of Rabbits in WA has been adapted for use in Western Australia and is based on the MCOPIHR. ${ }^{378}$ Its objective is to assist all persons handling or using rabbits in Western Australia. It is not intended to be used for either audit or compliance purposes, ${ }^{379}$ however its adoption can be used as defence against alleged cruelty to animals. ${ }^{380}$

Under the Animal Welfare Act 2002 (WA), it is a defence to prosecution for a person to prove that the person was authorised by or under a written law to do the act that is alleged to constitute the offence, and did the act in a humane manner. ${ }^{381}$ However, the Western Australian Meat Industry Authority Act 1976 (WA), responsible for establishing the Authority to provide for a system of approval of abattoirs, ${ }^{382}$ does not include any conditions of welfare to animals within abattoirs. Also, under the Animal Welfare (General) Regulations 2003 (WA), the use of electric stunning in abattoirs does not include the rabbit as a species. ${ }^{383}$

The Food Regulations 2009 (WA), which provides for the safety and suitability of food for human consumption, adopts two standards which contain general animal welfare provisions such as transport, restraining and stunning. ${ }^{384}$ Those standards are the Australian Standard for Hygienic Production of Rabbit Meat for Human Consumption (AS 4466:1997) and the Australian Standard for the Hygenic Production and Transportation of Meat and Meat Products for Human Consumption (AS 4696:2007). ${ }^{385}$

\subsubsection{Rabbits used in Scientific Research}

The use of animals in research is regulated by the National Health and Medical Research Council (NHMRC) Australian Code for the Care and Use of Animals for Scientific Purposes 8th edition (2013) ${ }^{386}$ (in this section, the Research Code) which is given legal status under every State and Territory based animal welfare legislation. ${ }^{387}$

The Research Code's objective is to promote humane and responsible care and use of animals for scientific purposes. ${ }^{388}$ A principle rule within the Research Code requires an Animal Ethics Committee (AEC) for all scientific institutes. The main role of these committees is to '[b]e satisfied that there is sufficient evidence to support a case that the proposed use of animals is justified' ${ }^{389}$ A key condition of a research licence or research breeding facility is for the licensee to comply with the Research Code. ${ }^{390}$

Part of the responsibilities of a governing body of an institution under the Research Code is to ensure that guidelines for animal care and use are developed in consultation with the AEC, approved by the AEC, and implemented and promoted within the institution. ${ }^{391}$

\section{New South Wales}

In NSW animal research is regulated under the Animal Research Act 1985 (NSW) and the Animal Research Regulation 2010 (NSW). Section 24(1)(e) of the Prevention of Cruelty to Animals Act 1979 (NSW)

377 Animal Welfare Act 2002 (WA) s 23.

378 Department of Local Government and Regional Development (WA) The Code of practice for keeping of Rabbits in Western Australia, 2003 (State of Western Australia, 2003).

379 Ibid Preface

$<$ https://www.agric.wa.gov.au/sites/gateway/files/Code\%20of\%20Practice\%20for\%20Keeping\%20Rabbits\%20in\%20Western\%20 Australia_0.pdf $>$.

380 Animal Welfare Act 2002 (WA) s. 25; Animal Welfare Act 2002 (WA) s 94(2)(d); Animal Welfare Regulation 2003 (WA) r 6 381 Animal Welfare Act 2002 (WA) s22.

382 Western Australian Meat Industry Authority Act 1976 (WA) s 17

383 Animal Welfare (General) Regulations 2003 (WA) Regulation 7 7. Use of devices - electric shock.

384 Australian Standard for Hygienic Production of Rabbit Meat for Human Consumption, SCARM Report 59, AS 4466:1997; Australian Standard for Hygienic Production of Rabbit Meat for Human Consumption, SCARM Report 59, AS 4466:1998; Australian Standard for the Hygienic Production of Meat and Meat Products for Human Consumption, FRSC Technical Report No. 3, AS 4696: 2007.

385 Food Regulations 2009 (WA) Division 2 under section 144(6) of the Food Act 2008 (WA).

386 National Health and Medical Research Council, Australian Code of Practice of the Care and Use of Animals for Scientific Purposes 8th Edition 2013 (National Health and Medical Research Council, 8th ed, 2013).

387 BRUCE, A., Animal Law in Australia: An Integrated Approach (LexisNexis Butterworths, 2nd ed, 2018) 260.

388 National Health and Medical Research Council, Australian Code of Practice of the Care and Use of Animals for Scientific Purposes 8th Edition 2013 (National Health and Medical Research Council, 8th ed, 2013) 1.

389 Ibid 5.

390 See Prevention of Cruelty to Animals Regulations 2008 (Vic) r 32; Prevention of Cruelty to Animals Regulations 2008 (Vic) r 92 ; Animal Welfare Act 2002 (WA) s6.

391 National Health and Medical Research Council, Australian Code of Practice of the Care and Use of Animals for Scientific Purposes 8th Edition 2013 (National Health and Medical Research Council, 8th ed, 2013).s2.1.5(v). 
directly exempts animals used for scientific purposes from the protection of the animal welfare Act. The exemptions apply to using or supplying animals for research and procedures undertaken in accordance with the provisions of the Animal Research Act 1985 (NSW). ${ }^{392}$ For example, under the Animal Research Regulation 2010 (NSW), certain schools are permitted to perform animal research without accreditation. ${ }^{393}$

The Research Code is adopted under the Animal Research Act 1985 (NSW) ${ }^{394}$ Under the previous Australian Code of Practice for the Care and Use of Animals for Scientific Purposes 7th Edition (2004), a list of species-specific guidelines for animal care were drafted by the NSW Animal Research Review Panel (ARRP) ${ }^{395}$ for the use in the 2004 Research Code. ${ }^{396}$ According to the ARRP, those guidelines have been removed in the current edition (8th edition 2013) of the Research Code to allow for regular revisions incorporating new knowledge. ${ }^{397}$

The ARRP define the scope of their guidelines as follows:

'Guidelines are more flexible documents as they establish principles to be adopted in undertaking specific activities and allow scope for interpretation and adaptation in the implementation of a course of action, 398

There are no rabbit specific guidelines adopted within the Animal Research Act 1985 (NSW). However the Guidelines for the Care and Housing of Rabbits in Scientific Institutions ${ }^{399}$ as listed under the ARRP Guidelines and Policies specify the need for accommodation that meets the species-specific needs of rabbits while at the same time taking into account the requirements of the research for which the animals are being used. $^{400}$

\section{Victoria}

In Victoria, the Prevention of Cruelty to Animals Regulations 2008 (Vic) includes a separate part for scientific procedures and prescribed conditions for scientific procedure licences. ${ }^{401}$ The prescribed conditions include that all scientific procedures be carried out in accordance with the Research Code, ${ }^{402}$ the Code of Practice for the Housing and Care of Laboratory Mice, Rats, Guinea Pigs and Rabbits ${ }^{403}$ and the Code of Practice for the Use of Animals from Municipal Pounds in Scientific Procedures. ${ }^{404}$ Scientific procedures must be carried out with the approval of an Animal Ethics Committee (AEC). ${ }^{405}$

The Code of Practice for the Housing and Care of Laboratory Mice, Rats, Guinea Pigs and Rabbits ${ }^{406}$

392 Prevention of Cruelty to Animals Act 1979 (NSW) s 24(1)(e) .

393 Division 4 Exemptions from the Act: r15: Certain schools may carry on animal research without accreditation.

(1) A non-government school is exempt from the operation of section 46 (1) of the Act with respect to the carrying on of the business of animal research:

(a) if the school belongs to, or is associated with, a relevant Association that is accredited under the Act, and (b) so long as any animal research carried out at the school is carried out with the authority of an ethics committee for the relevant Association and in accordance with the Code of Practice.

(2) In this clause, relevant Association means any of the following:

(a) the Association of Independent Schools of New South Wales Limited,

(b) the Catholic Education Commission NSW.

394 Adopted under the Animal Research Act 1985 (NSW) s4 and defined under s3 of the Animal Research Regulations 2010 (NSW). 395 The Animal Research Review Panel is a statutory body under the Animal Research Act 1985 (NSW). It has twelve members who are appointed by the Minister for Primary Industries. There is equal representation from the sectors of industry, government and animal welfare. Animal Ethics Infolink, Animal Research Review Panel <https://www.animalethics.org.au/animal-research-review-panel>. 396 National Health and Medical Research Council, Australian Code of Practice of the Care and Use of Animals for Scientific Purposes 7th Edition 2004 (National Health and Medical Research Council, 7th ed, 2004) appendix 3.

397 Animal Ethics Infolink, Animal Care <https://www.animalethics.org.au/policies-and-guidelines/animal-care >

398 Animal Ethics Infolink, Policies and Guidelines <https://www.animalethics.org.au/policies-and-guidelines $>$.

399 Department of Agriculture (NSW) ARRP Guideline 18: Guidelines for the Housing of Rabbits in Scientific Institutions, 2003 (State of New South Wales, 2003) <https://www.animalethics.org.au/_data/assets/pdf_file/0013/222511/housing-rabbits-scientificinstitutions.pdf $>$.

400 Ibid.

401 Prevention of Cruelty to Animals Regulations 2008 (VIC) r 32.

402 National Health and Medical Research Council, Australian Code of Practice of the Care and Use of Animals for Scientific Purposes 8th Edition 2013 (National Health and Medical Research Council, 8th ed, 2013).

403 Department of Primary Industries (Vic) Code of Practice for the Housing and Care of Laboratory Mice, Rats, Guinea Pigs and Rabbits, 2004 (State of Victoria, 2004). <https://www.deakin.edu.au/_data/assets/pdf_file/0003/536628/620-codeofpracticehousing-and-care.pdf $>$.

404 Prevention of Cruelty to Animals Act 1986 (Vic) s 32; Prevention of Cruelty to Animals Regulation 2008 (Vic) r92

405 Prevention of Cruelty to Animals Regulation 2008 (Vic) r 37

406 Department of Primary Industries (Vic) Code of Practice for the Housing and Care of Laboratory Mice, Rats, Guinea Pigs and Rabbits, 2004 (State of Victoria, 2004). 
is mandatory under the Prevention of Cruelty to Animals Act 1986 (Vic) ${ }^{407}$ and Prevention of Cruelty to Animals Regulations 2008 (Vic). ${ }^{408}$ It establishes minimum standards for the housing and care of the animals listed within the Research Code including rabbits. ${ }^{409}$ The Code of practice for the use of animals from municipal pounds in scientific procedures provides information relating to the use of animals from municipal pounds in scientific procedures. ${ }^{410}$

\section{Western Australia}

In Western Australia, Part 2 of the Animal Welfare Act 2002 (WA) sets out provisions for licences required to deal with animals within scientific procedures. The Act offers defences for alleged cruelty such as those committed in accordance with accepted husbandry practices in breeding establishments, ${ }^{411}$ for prescribed surgical or similar operations, practices and activities, ${ }^{412}$ or if a person was acting within a specified code of practice. ${ }^{413}$

In WA, the Research Code is adopted under the Animal Welfare Act 2002 (WA). ${ }^{414}$ There are no specific codes for the housing of rabbits within WA research facilities, however, as with NSW, the Guidelines for the care and housing of rabbits in scientific institutions ${ }^{415}$ is a reference document provided through the ARRP and can be used as a guideline by the governing institutional body in compliance with the AEC.

The total number of rabbits used in scientific research in NSW, Vic and WA for the years 2012-2016 is tabulated below. ${ }^{416}$ There are no current statistics for the years 2017/2018.

\begin{tabular}{|l|l|l|l|}
\hline Year & NSW & Vic & WA \\
\hline 2016 & 1649 & 1464 & 143 \\
\hline 2015 & 1464 & 1500 & 189 \\
\hline 2014 & 1922 & 1449 & 12 \\
\hline 2013 & 1771 & 1666 & 228 \\
\hline 2012 & 1393 & 1529 & - \\
\hline
\end{tabular}

Table (6) number of rabbits used in scientific research between the years 2012-2016

Although the Research Code is attempting to incorporate the 3Rs (Reduction, refinement and replacement), ${ }^{417}$ the number of rabbits used in research indicated by Table 6 fluctuates but note that in NSW they rose from 2015 to 2016. As shown in Table 3, animals used in research are exempted from the animal welfare Act through the adoption of the Research Code under the animal welfare Acts (WA and Vic) or by exempting research animals directly from the Animal welfare Act such as in $\mathrm{NSW}^{418}$ and regulating them into the Animal Research Regulation 2010 (NSW) underpinned by the Research Code. Performing research on animals in accordance with an AEC appointed as the ultimate decision maker, whose members are appointed by the institutions ${ }^{419}$ which they oversee, raises questions regarding the possibility of bias in decision making. The AEC can therefore exempt animals from certain procedures that are deemed cruel under the animal welfare Acts such as the conditions of setting or using small or large leg-hold traps, ${ }^{420}$ if it was deemed as an appropriate scientific procedure.

407 Prevention of Cruelty to Animals Act 1986 (Vic) s 32 408 Animals Regulations 2008 (Vic) r 92(2).

409 Department of Primary Industries (Vic) Code of Practice for the Housing and Care of Laboratory Mice, Rats, Guinea Pigs and Rabbits, 2004 (State of Victoria, 2004).

410 Department of Agriculture (Vic) Code of practice for the use of animals from municipal pounds in scientific procedures, 1988 (State of Victoria, 1988).

411 Animal Welfare Act 2002 (WA) s 23.

412 Animal Welfare Act 2002 (WA) s 30.

413 Ibid s 25.

414 Ibid s 94(2)(d) and part 2.

415 Department of Agriculture (NSW) ARRP Guideline 18: Guidelines for the Housing of Rabbits in Scientific Institutions, 2003 (State of New South Wales, 2003).

416 Humane Research Australia, Statistics <http://www.humaneresearch.org.au/statistics/>.

417 BRUCE, A., Animal Law in Australia: An Integrated Approach (LexisNexis Butterworths, 2nd ed, 2018) 256.

418The Prevention of Cruelty to Animals Act 1979 (NSW) s 24(1)(e).

419 See for example Part 3 of the Animal Research Act 1985 (NSW).

420 Prevention of Cruelty to Animals Regulations 2008 (NSW) Regulation 32(7) Sub-regulations (2) to (6)** do not apply in circumstances where the use has been otherwise approved by an Animal Ethics Committee for research approved under license in accordance with Part 3 of the Act.

** Conditions of setting or use of small and large leg-hold traps. 


\subsubsection{Rabbits in the Pet Industry}

\section{New South Wales}

In NSW rabbits in the pet industry are protected by the Prevention of Cruelty to Animals Act 1979 (NSW) and the Prevention of Cruelty to Animals Regulations 2012 (NSW). There are two codes of practice which regulate the pet industry in NSW, the Animal Welfare Code of Practice-Animals in Pet Shops ${ }^{421}$ and the Animal Welfare Code of Practice No 1-Companion Animal Transport Agencies within NSW, ${ }^{422}$ both of which are adopted and mandatory under the Prevention of Cruelty to Animals Act 1979 (NSW). ${ }^{43}$

Under the Animal Welfare Code of Practice-Animals in Pet Shops, there is no specification of animal welfare for euthanasia of a rabbit. Section 8.3.1.2 of the Animal Welfare Code of Practice-Animals in Pet Shops requires that the euthanasia of unhealthy dogs and cats must be performed only by a veterinary surgeon or a person who is an authorised euthanasia technician. ${ }^{424}$ The definition of authorised euthanasia technician' is '[a] person who has acquired competency (through training, qualifications and experience) in humanely destroying dogs and cats. ${ }^{425}$ There is no explicit instruction on the humane euthanasia of rabbits in pet shops. The Code of Practice No.2-Animals in Pet Shops published in 2004, a precursor to the current code, included that the 'euthanasia procedure' for all other animals besides cats and dogs be performed by 'any competent person' ${ }^{426}$ The lack of specification of method of euthanasia for rabbits in pet shops leaves open a door for animal welfare breaches.

\section{Victoria}

In Victoria, the Code of Practice for the Operation of Pet Shops includes rabbits and is mandatory under the provisions of the Domestic Animals Act $1994 .{ }^{427}$ In contrast to NSW, the assigned Code of Practice for the Operation of Pet Shops ${ }^{428}$ in Victoria specifies that a Veterinarian is required for the treatment of animals and for humane euthanasia where an overdose of barbiturate is used. ${ }^{429}$

\section{Western Australia}

In Western Australia, companion animals are protected from animal cruelty under the Animal Welfare Act 2002 (WA) ${ }^{430}$ There are no specific animal welfare codes relating to rabbits as companions under the Act. The Department of Mines, Industry Regulation and Safety, and the Royal Society for the Prevention of Cruelty to Animals, Western Australia (RSPCA) have published a brochure to assist consumers in making an informed decision when buying a pet which includes a section on caring for rabbits. ${ }^{431}$

Across all three states (NSW, Vic and WA) there are no specific animal welfare Codes of Practice for the breeding and rearing of rabbits within the pet industry. The NSW Animal Welfare Code of Practice Breeding Dogs and Cats ${ }^{432}$ and the Victorian Code of Practice for the Operation of Breeding and Rearing Businesses ${ }^{433}$ define 'animal' as 'dog, cat, puppy or kitten'. While in WA, there are Codes of Practice for Dog

421 Department of Primary Industries (NSW), Animal Welfare Code of Practice: Animals in Pet Shops 2008 (State of New South Wales, 2008) <https://www.dpi.nsw.gov.au/_data/assets/pdf_file/0019/244018/Animal-welfare-code-of-practice-animals-in-petshops.pdf $>$.

422 Department of Primary Industries (NSW), NSW Animal Welfare Code of Practice No 1 - Companion animal transport agencies, 1996 (State of New South Wales, 1996). <https://www.dpi.nsw.gov.au/animals-and-livestock/animal-welfare/general/codes-ofpractice/aw-code-1>.

423 Prevention of Cruelty to Animals Act 1979 (NSW) s 4(1); Prevention of cruelty to Animals regulations 2012 (NSW) r 25 and Schedule1.

424 Department of Primary Industries (NSW), Animal Welfare Code of Practice: Animals in Pet Shops 2008 (State of New South Wales, 2008) s 8.3.1.2.

425 Ibid s3.2.2.

426 O’SULliVAN, S., Animals, Equality and Democracy (Palgrave MacMillan, 2011) 122.

427 Domestic Animals Act 1994 (Vic) s 59.

428 Adopted under section 59 of the Domestic Animals Act 1994 (Vic). See notice of the making of which was published in Government Gazette No. G13 on 4 April 1996, page 847.

429 Department of Agriculture (Vic),Code of Practice for the Operation of Pet shops (State of Victoria), s1.2

430 Animal Welfare Act 2002 (WA) s 3

431 Western Australian Department of Mines, Industry Regulation and Safety, A Consumer's guide to buying a pet $<$ https://www.commerce.wa.gov.au/sites/default/files/atoms/files/aconsumersguidetobuyingapet_0.pdf $>$.

432 Department of Primary Industries (NSW), Animal Welfare Code of Practice - Breeding Dogs and Cats 2009 (State of New South Wales, 2009) 3.

433 Department of Economic Development, Jobs, Transport and Resources (Vic) Code of Practice for the Operation of Breeding and Rearing Businesses 2018 (State of Victoria, 2018).

140 Derecho Animal. Forum of Animal Law Studies, vol. 10/2 
Breeders only. ${ }^{434}$ The MCOPIHR, the Code of practice for keeping of Rabbits in WA and Code of practice for the intensive husbandry of rabbits Vic as listed in Table 3 do not specify the commercial industries they encompass. Instead, they state that they are guidelines for all persons responsible for the intensive husbandry of domestic-type rabbits for commercial production. Therefore, it can be assumed that rabbits in the pet breeding industry can also fall under the care and management of one of those aforementioned three codes.

The following three charts summarise the regulatory regime for the industries discussed in sections 3.3.1 and 3.3.2 in NSW, Vic and WA.

In the following section, I use examples to illustrate how the protection of rabbits as examined in this section is applied in different scenarios and use them to identify areas where animal welfare fails to protect the domestic rabbit.

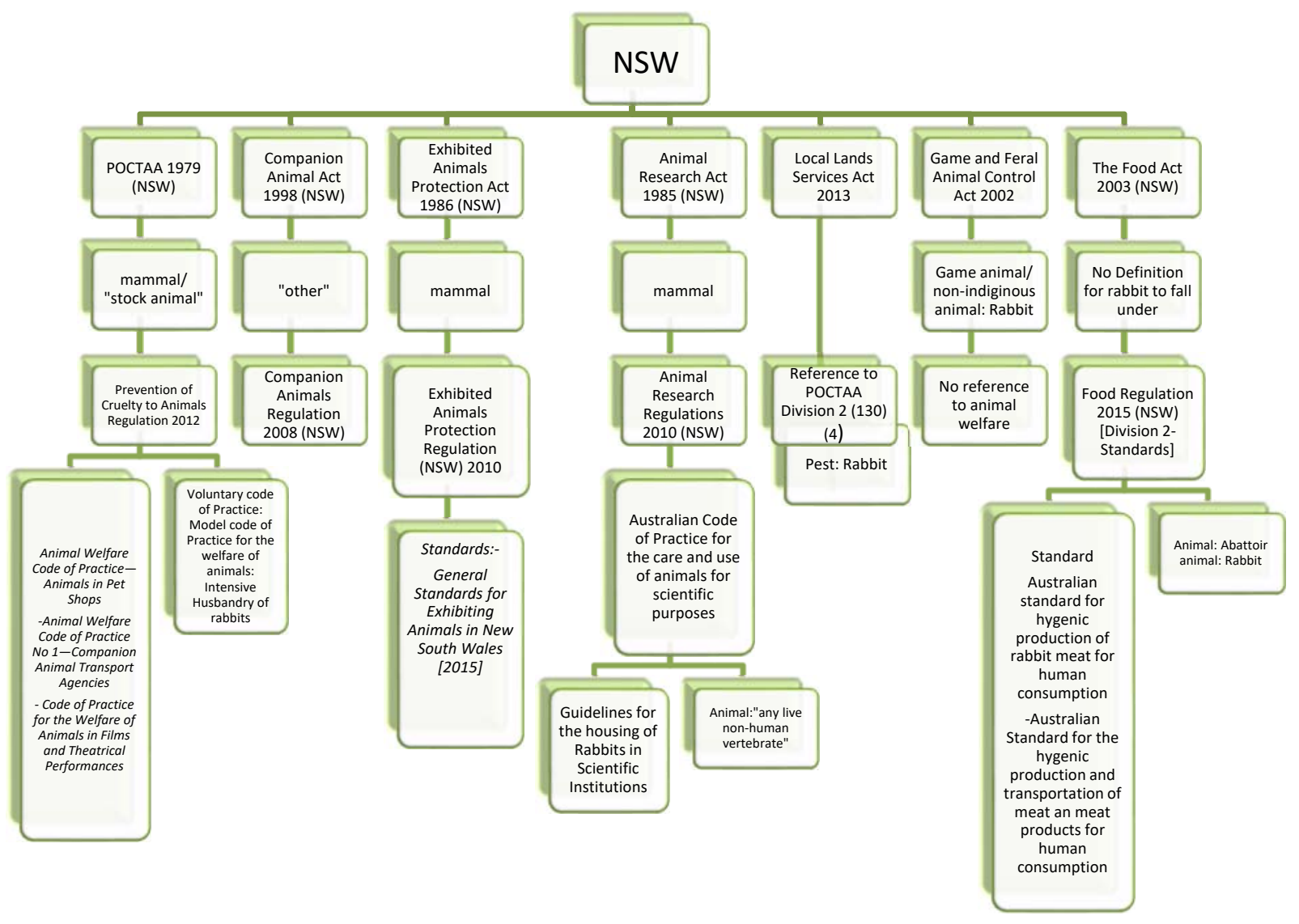

Figure 1 Chart Summarising Legislation under which Rabbits Fall in NSW 


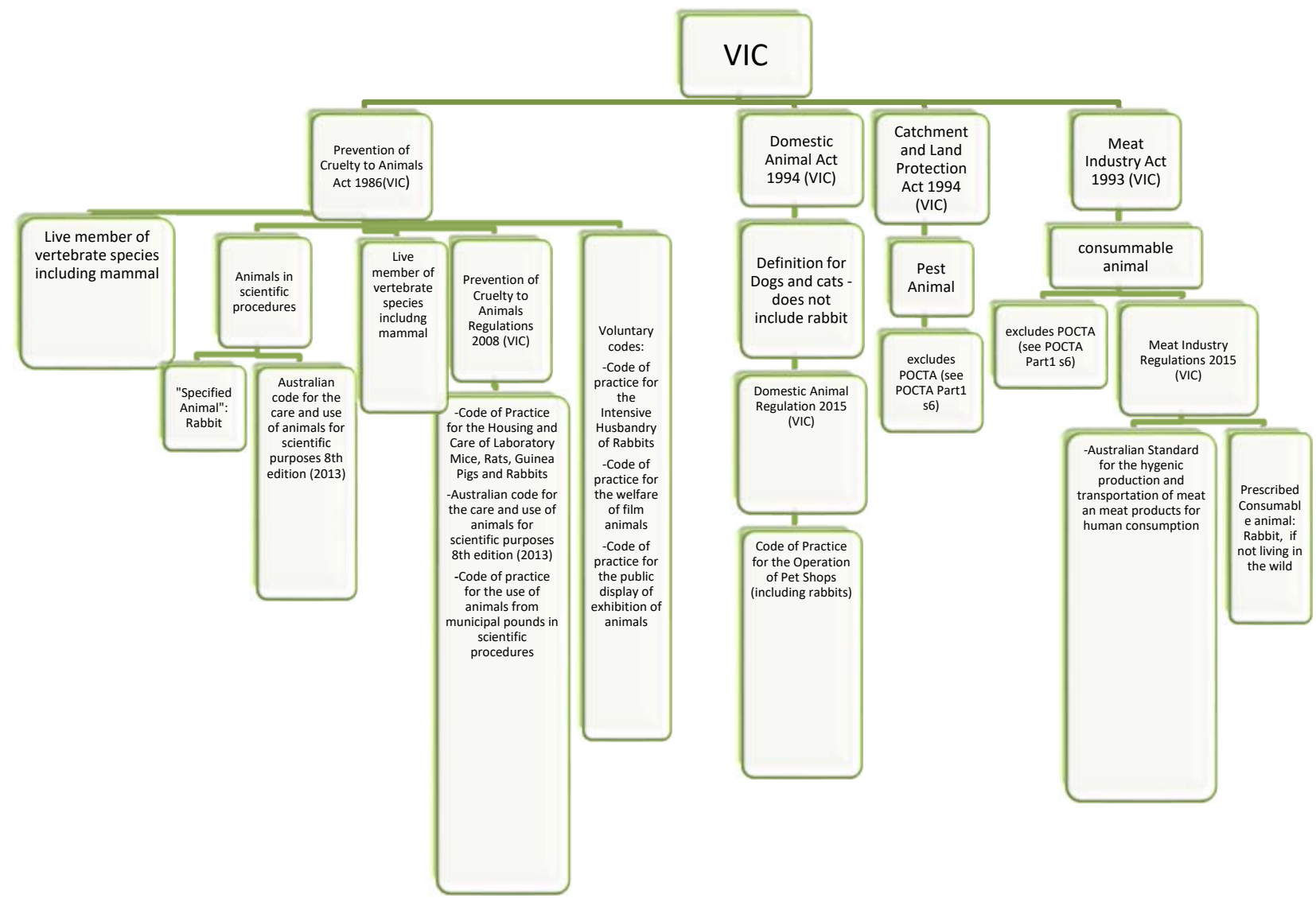

Figure 2 Chart Summarising Legislation under which Rabbits Fall in Vic

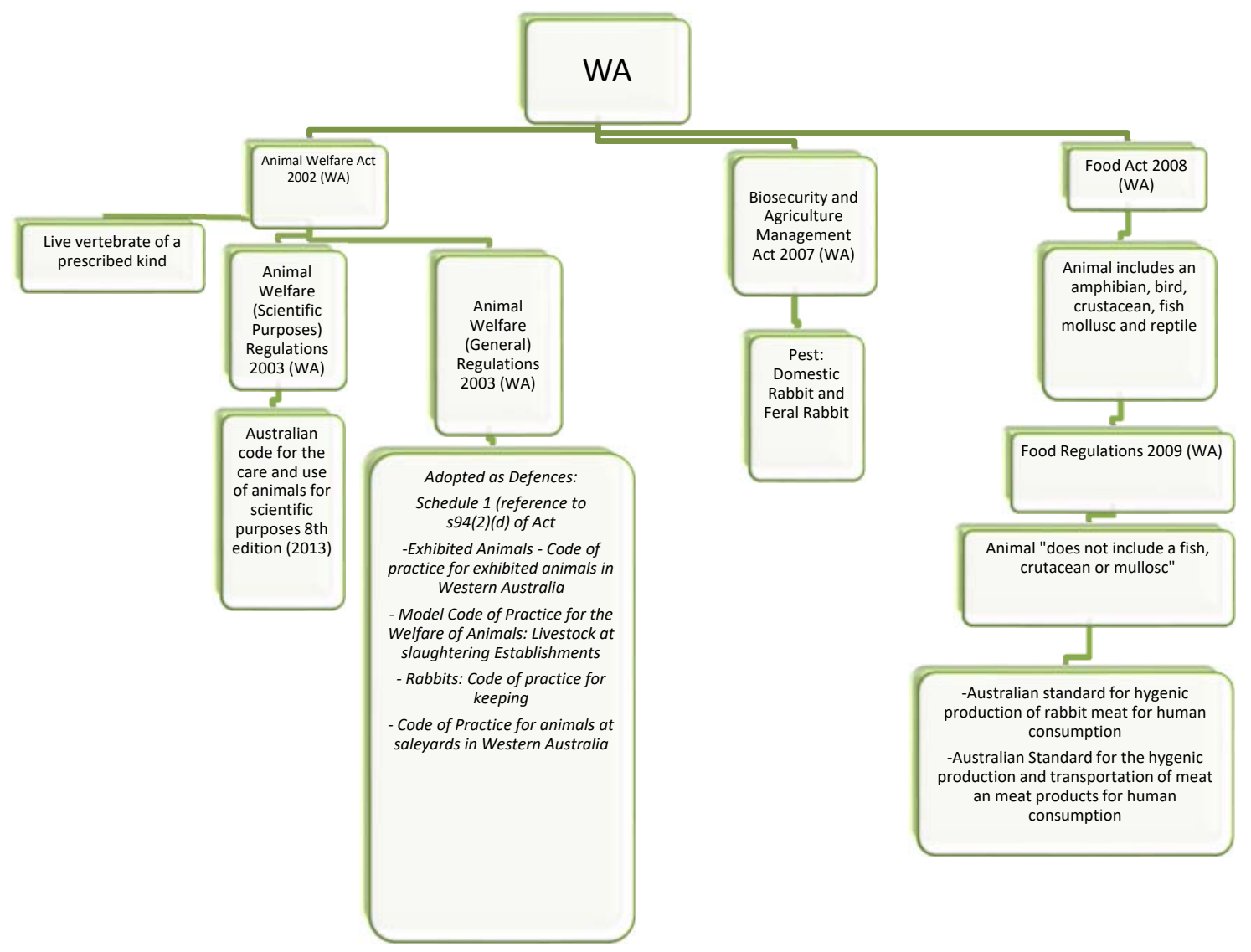

Figure 3 Chart Summarising Legislation under which Rabbits Fall in WA 


\subsection{The Effect of the Application of Animal Welfare Laws Under Different Industries}

Section 3.3 examined how the domestic rabbit is regulated under different contexts of use. Following from that analysis, this section looks at the effect some of the different applications of the animal welfare laws, investigated in the previous section, have on the rabbit species to identify animal welfare issues arising from that. I present two examples:

Example I follows the possible scenarios of a domestic rabbit under a wide spectrum of human uses and identifies the fluctuation of animal welfare laws during their lifetime.

Example II compares standards of practice of husbandry underpinning the animal welfare regime of rabbits used in the meat industry to those used for the welfare of rabbits in scientific research.

\section{Example I: A Rabbit is a Rabbit but Not Under the Law}

In the following example, I expand on O'Sullivan's story of 'bugs the rabbit' ${ }^{435}$ by changing jurisdictions from NSW to Victoria. The example is used to highlight the copious changes of animal welfare protection the domestic rabbit can fall under throughout their lifetime.

In this story I tell the story of Freddie, a New Zealand White Rabbit, who starts his life in a pet shop in Melbourne, Victoria. Within the pet shop, Freddie is protected by several statutes; the Prevention to Cruelty Act 1986 (Vic), ${ }^{436}$ the Prevention of Cruelty to Animals Regulations 2008 (Vic), the Domestic Animal Act 1994 (Vic) ${ }^{437}$ and the Code of Practice for the Operation of Pet Shops ${ }^{438}$ The code of practice for the Operation of Pet Shops lists minimum standards of accommodation, ${ }^{439}$ management and care which are appropriate to the welfare, physical and behavioural needs of pet animals held for sale in pet shops registered under the Act. ${ }^{440}$

A child walks into the pet store at Easter and purchases Freddie at 5 weeks old. ${ }^{441}$ Freddie now moves from being the property of the store owner to becoming the property of the boy, so Freddie will be protected by the Prevention of Cruelty to Animals Act 1986 (Vic) which entitles Freddie to food, drink and shelter ${ }^{442}$ as well as protection from 'unreasonable pain or suffering'. ${ }^{443}$ The boy however stops cleaning Freddie's cage, so the parents think that the upkeep of the rabbit is too hard and set Freddie loose into the bushland. ${ }^{444} \mathrm{He}$ is now roaming free out of an enclosure and will be deemed as a 'pest animal' by the Catchment and Land Protection Act 1994 (Vic), where animal welfare laws do not apply to him. ${ }^{445}$ In the bush, Freddie gets caught by a trap.

The trapper sees that Freddie's leg has not been damaged much and he stops him from bleeding. He now decides that Freddie could make him a few dollars, so sells him to a laboratory technician at a research facility, where the Australian Code of Practice for the Care and the Use of Animals for Scientific purposes, the Code of Practice for the Housing and Care of Laboratory Mice, Rats, Guinea Pigs and Rabbits and the Code of Practice for the Use of Animals from Municipal Pounds in Scientific Procedures are all mandatory under the Prevention of Cruelty to Animals Act 1986 (Vic) ${ }^{446}$ and the Prevention of Cruelty to Animals Regulations 2008 (Vic). Under the Prevention of Cruelty to Animals Act 1986 (Vic), Freddie is now classified as 'a specified animal (b): a rabbit'. ${ }^{447}$ Depending on the experiment, Freddie might now be entitled to a

435 O’SUlLIVAN, S., Animals, Equality and Democracy (Palgrave MacMillan, 2011) 35.

436 Under the Prevention of Cruelty to Animals Act 1986 (Vic) s3(3) Freddie is falls under the definition of 'mammal'.

437 Note, the purpose of the Domestic Animals Act 1994 (Vic) is to promote animal welfare and the responsible ownership of dogs and cats. By definition of 'prescribed animal', the domestic rabbit could fall under the Act however all sections are listed specifically for cats and dogs. The Act is part of the regulation of council pounds and pet shops and therefore the rabbit might inherently fall under the Act. The Code of Practice for the Operation of Pet Shops falls under the Domestic Animals Act 1994 (Vic) s59.

438 Domestic Animals Act 1994 (Vic) s59.

439 According to the Code of Practice for the Operation of Pet Shops, the minimum cage space is $0.6 \mathrm{~m} \times 0.5 \mathrm{~m}$ for a max of 6 rabbits. Department of Agriculture (Vic), Code of Practice for the Operation of Pet shops (State of Victoria) Appendix 1.

440 Department of Agriculture (Vic), Code of Practice for the Operation of Pet Shops (State of Victoria).

441 According to the FAO, Weaning (separation of doe and young) takes place after 4-5 weeks. The Code of Practice for the Operation of Pet Shops in Victoria allows the sale of rabbits at 5 weeks. Department of Agriculture (Vic), Code of Practice for the Operation of Pet shops (State of Victoria).

442 Prevention of cruelty to Animals Act 1986 (Vic), s 9(f).

443 Ibid $9(1)(c)$ 'unreasonable pain or suffering that is caused'.

444 Note under Prevention of cruelty to Animals Act 1986 (Vic), s 9(1) (h) 'it is an act defined as cruelty if a person abandons an animal of a species usually kept in a state of confinement or for a domestic purpose'.

445 Prevention of cruelty to Animals Act 1986 (Vic) s 6(d) 'The Act does not apply to anything done in accordance with the Catchment and Land Protection Act 1994 (Vic).

446 Prevention of cruelty to Animals Act 1986 (Vic), s 36

447 Ibid s 25(a) 
nesting box with straw, however he is by law allowed to be starved from water and food for experimentation. Next, the research department stops the funding, so the lab assistant decides to sell him on eBay.

A meat farmer spots Freddie on eBay and buys him as a main buck ${ }^{448}$ for his intensive meat farm production unit. Now Freddie's daily welfare falls under a voluntary code of practice, the Code of practice for the intensive husbandry of rabbits Vic, where he spends one year as a breeding buck in an isolated cage with minimum animal welfare protection before he is sent to slaughter. Under section 6 of the Prevention of cruelty to Animals Act 1986 (Vic) Freddie is exempted and falls under the Meat Industry Act 1993 (Vic) defined as a 'Prescribed Consumable animal: Rabbit'. 449

Within a year, Freddie goes from being a family companion animal to 'pest' animal, laboratory animal and finally an animal kept for meat production. Each of those hold Freddie under different protections, either giving him protection from 'unnecessary' or 'unjustified' cruelty or exempting him from the operation of animal welfare Acts. One of the issues highlighted by this example is the nature of animal welfare legislation which does not take into account the fact that a rabbit is a sentient being with intrinsic interests that must be protected regardless of the industry they fall under. Instead, as many have highlighted with other animal use industries, ${ }^{450}$ animal welfare protecting the domestic rabbit is informed by context of use and not species dependent and has little to do with actual suffering and wellbeing considerations.

\section{Example II: A Comparison of Husbandry Practices in Two Rabbit Use Industries}

In this example, husbandry practices written for the welfare of domestic rabbits within the scientific research industry are compared to those written for rabbits used in the meat industry to identify any disparities between animal welfare instruments based on one species under two different contexts. Those two industries have been chosen as they are both based on one breed of rabbit, the New Zealand White, ${ }^{451}$ which is a medium sized breed of domesticated rabbit, mostly bred for rabbit meat ${ }^{452}$ and scientific research industries. ${ }^{453}$ Referring to the same breed of rabbit makes the animal welfare aspects of husbandry easier to compare.

The provisions analysed below in Table (7) are set against the requirements of the Five Freedoms as a threshold for analysis of the welfare of rabbits because the Five Freedoms can be used to assess the animal's physical and psychological state according to the RSPCA. ${ }^{454}$ Therefore, the following provisions of animal welfare are compared:

- Food and drink; ${ }^{455}$

- Environment and space requirements; ${ }^{456}$

- Health and veterinary care; 457

- Social considerations; ${ }^{458}$

- Environmental enrichment and slaughter. ${ }^{459}$

The Model Code of Practice for the Welfare of Animals: Intensive Husbandry of Rabbits (MCOPIHR) is the National Code written for the welfare of domestic rabbits within intensive production industries such as

448 A 'buck' is a male rabbit

449 The Australian Standard for Hygienic Production of Rabbit Meat for Human Consumption, SCARM Report 59, AS 4466:1997; For example, Australian Standard for the Hygienic Production of Meat and Meat Products for Human Consumption, FRSC Technical Report No. 3, AS 4696: 2007.

450 McEWAN, A.- and SKANDAKUMAR, K., The Welfare of Greyhounds in Australian Racing: Has the Industry Run its Course? (2011) 5 Australian Animal Protection Law Journal 53,20; WHITE, S., Regulation of Animal Welfare in Australia and the Emergent Commonwealth: Entrenching the Traditional Approach of the States and Territories or Laying the Ground for Reform? (2007) 35 Federal Law Review 347; O'SULLIVAN, S., Animals, Equality and Democracy (Palgrave MacMillan, 2011) 4.

451 For breed traits see Cross Roads Rabbitry, New Zealand Whites $<$ http://www.crossroadsrabbitry.com/about-new-zealand-whiterabbits/>.

452 A survey of rabbit farmers in NSW in 1999 showed that the predominant breed of meat rabbit is the New Zealand White. The Crusader research program for the development of intensive rabbit meat in Australia have also selected the NZ White for fastest growth traits. EADY, S., Farmed Rabbits in Australia (2003) 02/144 Rural Industries Research and Development Corporation.

453 See for example SUEN, W.W. et al, Experimental West Nile Virus Infection in Rabbits: An Alternative Model for Studying Induction of Disease and Virus Control (2015) 4 Pathogens, 529-558.

454 RSPCA, Five Freedoms for Animals <http://kb.rspca.org.au/five-freedoms-for-animals_318.html>.

455 First Freedom: 'Freedom from hunger and thirst: by ready access to fresh water and a diet to maintain full health and vigour'.

456 Second Freedom: 'Freedom from discomfort: by providing an appropriate environment including shelter and a comfortable resting area'.

457 Third Freedom: 'Freedom from pain, injury or disease: by prevention through rapid diagnosis and treatment'.

458 Fourth Freedom: 'Freedom to express normal behaviour: by providing sufficient space, proper facilities and company of the animal's own kind'.

459 Fifth Freedom: 'Freedom from fear and distress: by ensuring conditions and treatment which avoid mental suffering'.

144 Derecho Animal. Forum of Animal Law Studies, vol. 10/2 
rabbits bred for meat. ${ }^{460}$ In New South Wales, the Australian Guidelines for the Housing of Rabbits in Scientific Institutions are the guidelines referenced by the Animal Research Review Panel (ARRP) for the rabbit species used in scientific research ${ }^{461}$ while in Victoria the Code of Practice for the Housing and Care of Laboratory Mice, Rats, Guinea Pigs and Rabbits ${ }^{462}$ sets the minimum standards for the husbandry of rabbits used for scientific experiments and is mandatory under the Prevention of Cruelty to Animals Act 1986(Vic). ${ }^{463}$

For the purposes of the comparison within this example, I have chosen to use the Australian Guidelines for the Housing of Rabbits in Scientific Institutions (Aust. Guide. Hsing Rab. Scient. Inst.) as the main husbandry document pertaining to the research industry to compare with the MCOPIHR mainly because the space provisions in both documents are based on the New Zealand breed of rabbits. ${ }^{464}$ However, to compare the provision of welfare in euthanasia to that within the MCOPIHR, the Code of Practice for the Housing and Care of Laboratory Mice, Rats, Guinea Pigs and Rabbits (Code of Prac. Hsing. Lab Mice, Rats, Guineas, Rabs) is referenced as no information on welfare standards of euthanasia is available in the Australian Guidelines for the Housing of Rabbits in Scientific Institutions (Aust. Guide. Hsing. Rab. Scient. Inst.).

Note that the MCOPIHR was first published in 1991 and has not been updated, while the (Aust. Guide. Hsing Rab. Scient. Inst.) and the (Code of Prac. Hsing Lab Mice, Rats, Guineas, Rabs) were published in 2003 and 2004 respectively. Each of the guidelines and the MCOPIHR have a disclosure statement which states that they will be revised subject to the advances in the understanding of rabbit physiology, behaviour, technological advances, and changes in community attitudes ${ }^{465}$ and expectations about the welfare of animals, however none have been updated since their outset. Table (7) summarises the findings in this example.

\begin{tabular}{|c|c|c|}
\hline $\begin{array}{l}\text { Provision based on } \\
\text { the five Freedoms }\end{array}$ & MCOPIHR & $\begin{array}{l}\text { (Aust. Guide. Hsing Rab. Scient. Inst.) / } \\
\text { (Code of Prac. Hsing Lab Mice, Rats, } \\
\text { Guineas, Rabs) }\end{array}$ \\
\hline & Rabbit (domesticated European) & Rabbit (domesticated European) \\
\hline FOOD \& WATER & $\begin{array}{l}\text { Diet: 'nutritionally adequate'. Clean water } \\
\text { at all times, automated watering system. } \\
\text { Drinking nipples at right height checked } \\
\text { every day with backup system }\end{array}$ & $\begin{array}{l}\text { It is recommended that foods such as hay, } \\
\text { fruits, vegetables, legumes or green feeds be } \\
\text { fed to supplement commercial pellets and to } \\
\text { reduce the monotony of a fixed ration diet. } \\
\text { Potable water must be available to all animals } \\
\text { at all times }\end{array}$ \\
\hline ENVIRONMENT & Temperature optimal range (10C-25C) & $\begin{array}{l}\text { A temperature range for rabbit housing of } 15 \\
-24 \mathrm{C} \text { is recommended } \\
\text { Enrichment is recommended by providing } \\
\text { sufficient space for exercise, social interaction } \\
\text { and play. The provision of environmental } \\
\text { enrichment is particularly important for singly } \\
\text { housed or caged rabbits, and the provision for } \\
\text { adequate exercise is fundamental to normal } \\
\text { skeletal and muscular development and } \\
\text { maintenance of all laboratory rabbits }\end{array}$ \\
\hline $\begin{array}{l}\text { SPACE } \\
\text { REQUIREMENTS }\end{array}$ & $\begin{array}{l}\text { Ventilation to prevent build-up of } \\
\text { moisture, ammonia and heat / Internal } \\
\text { surfaces smooth to avoid accumulation of } \\
\text { dust and fluff } \\
\text { Based on NZ white breed }\end{array}$ & $\begin{array}{l}\text { A regular light / dark cycle should be } \\
\text { provided. A relative humidity for rabbit } \\
\text { housing of } 45-65 \% \text { is recommended. A } \\
\text { ventilation rate of } 15-20 \text { air changes per hour } \\
\text { is recommended. Concentrations of ammonia } \\
\text { should not be allowed to exceed 10ppm } \\
\text { Based on NZ white breed }\end{array}$ \\
\hline
\end{tabular}

460 CSIRO Publishing and Primary Industry Standing Committee (Cth), Model Code of Practice for the Welfare of Animals: Intensive Husbandry of Rabbits (Primary Industries Report Series 33, 2003).

461 Department of Agriculture (NSW) ARRP Guideline 18: Guidelines for the Housing of Rabbits in Scientific Institutions, 2003 (State of New South Wales, 2003)

462 Department of Primary Industries (Vic) Code of Practice for the Housing and Care of Laboratory Mice, Rats, Guinea Pigs and Rabbits, 2004 (State of Victoria, 2004). <https://www.deakin.edu.au/_data/assets/pdf_file/0003/536628/620-codeofpracticehousing-and-care.pdf>

463 Prevention of Cruelty to Animals Act 1986 (Vic) s 32; Prevention of Cruelty to Animals Regulation 2008 (Vic) r 92.

464 For breed traits see Cross Roads Rabbitry, New Zealand Whites $<$ http://www.crossroadsrabbitry.com/about-new-zealand-whiterabbits/>.

465 Department of Agriculture (NSW) ARRP Guideline 18: Guidelines for the Housing of Rabbits in Scientific Institutions, 2003 (State of New South Wales, 2003) 3. 


\begin{tabular}{|c|c|c|}
\hline & $\begin{array}{l}\text { Cages for rabbits over } 12 \text { weeks old should } \\
\text { be not less than } 45 \mathrm{~cm} \text { high to allow rabbits } \\
\text { to stand up with ears fully erect }\end{array}$ & $\begin{array}{l}\text { The minimum space provided should allow } \\
\text { each rabbit to carry out its normal behaviour, } \\
\text { including a wide range of locomotory } \\
\text { behaviours, such as hopping, leaping, playing, } \\
\text { exploring and stretching out. } \\
\text { Ideally the cage height should allow rabbits to } \\
\text { rear up erect on their hind legs with their ears } \\
\text { pricked ( } 75 \mathrm{~cm} \text { for a New Zealand White } \\
\text { rabbit). }\end{array}$ \\
\hline EQUIPMENT & $\begin{array}{l}\text { Wire floor: woven or flat construction. } \\
\text { Square mesh max } 19 \times 19 \mathrm{~mm} \text { or } 13 \times \\
13 \mathrm{~mm} \text { for kits }\end{array}$ & $\begin{array}{l}\text { Plastic or metal dimple flooring should be } \\
\text { used in cages. } \\
\text { Materials that may be used in cage trays for } \\
\text { catching urine and faeces include sawdust, } \\
\text { wood shavings, corrugated paper, paper } \\
\text { sprinkled with absorbent powders, pelleted } \\
\text { paper, preformed cardboard trays and } \\
\text { absorbent pads. } \\
\text { Females should be provided with straw or } \\
\text { other suitable material such as hay or shredded } \\
\text { paper to spread in their nesting place } \\
\text { Nest boxes of about } 38 \mathrm{~cm} \times 25 \mathrm{~cm} \text { and } 20 \mathrm{~cm} \\
\text { high are recommended }\end{array}$ \\
\hline HEALTH & $\begin{array}{l}\text { Treat ailing/ injured rabbits promptly } \\
\text { otherwise humanely destroyed. seek } \\
\text { specialised advice. remove dead rabbits } \\
\text { immediately. Trim nails periodically }\end{array}$ & $\begin{array}{l}\text { Rabbits should be monitored by observation at } \\
\text { least daily. Health checks of individual rabbits } \\
\text { should be carried out at least weekly. Health } \\
\text { checks should include looking for signs of } \\
\text { malocclusion, overgrown claws, fight wounds } \\
\text { (especially underbelly wounds), sore hocks, } \\
\text { ear mites, diarrhoea and snuffles. Weekly } \\
\text { weighing should be carried out. } \\
\text { Rabbits that give cause for concern (either } \\
\text { excessively aggressive or timid) may need to } \\
\text { be removed from a group. }\end{array}$ \\
\hline $\begin{array}{l}\text { SOCIAL } \\
\text { BEHAVIOUR }\end{array}$ & No information available. & $\begin{array}{l}\text { Housing should be provided which allows } \\
\text { rabbits the opportunity for social interaction, } \\
\text { the opportunity to carry out normal behaviours } \\
\text { such as hopping and rearing upwards } \\
\text { (freedom of movement) and the opportunity to } \\
\text { rest and withdraw from each other. }\end{array}$ \\
\hline EUTHANASIA & $\begin{array}{l}\text { Destroyed humanely. Cervical dislocation } \\
\text { is an acceptable method. }\end{array}$ & $\begin{array}{l}\text { Chemical (Injectable). Neck dislocation not } \\
\text { acceptable: regarded as inhumane } \\
\text { ac6 }\end{array}$ \\
\hline
\end{tabular}

Table (7) Comparison of the code of practice for the welfare of rabbits in research and in intensive meat farms

Table 7 highlights the inconsistent nature of animal welfare in the treatment of rabbits under different industries. Both the Australian Guidelines for the Housing of Rabbits in Scientific Institutions and the MCOPIHR are based on the breed of the New Zealand White. In the case of space requirements, where the welfare of an animal, in accordance with the second and Fourth Freedom is for the freedom from discomfort ${ }^{467}$ and freedom to express natural behaviour by the provision of sufficient space, ${ }^{468}$ legislation favours rabbits in research, ultimately giving them enough space for three hops as compared to an area equivalent to an A4 sheet of paper in meat farms. However, the guidelines of housing animals within scientific institutions present ideological parameters within captive situations. Most research rabbits are not afforded the pleasures of

466 Note, euthanasia is not included within the Australian Guidelines for the Housing of Rabbits in Scientific Institutions. This entry comes from the Code of Practice for the Housing and Care of Laboratory Mice, Rats, Guinea Pigs and Rabbits in Victoria as adopted under the Code of Practice for the Care and Use of Animals for Scientific Purposes within the Prevention of Cruelty to Animals Act 1986 (Vic).

467 Second Freedom: 'Freedom from discomfort: by providing an appropriate environment including shelter and a comfortable resting area'.

468 Fourth Freedom: 'Freedom to express normal behaviour: by providing sufficient space, proper facilities and company of the animal's own kind'. 
hopping, running or socialising. ${ }^{469}$ As pointed out by Caulfield, the ultimate decision-making remains with the animal ethics committees, appointed by the research institutions whereby the welfare of the animals is subject to the procedures carried out and agreed to by the committee regardless of any guidelines. ${ }^{470}$ This is reflected in the mandatory Code of Practice for the Housing and Care of Laboratory Mice, Rats, Guinea Pigs and Rabbits in Victoria which describes that '[p]roposed variations to these standards, as part of an experimental or breeding protocol, must be justified to and approved by an Animal Ethics Committee'. ${ }^{471}$ Therefore, as pointed out by O'Sullivan, in many cases such as when a rabbit may be housed in a cage not bigger than its size for experiments such as muscle cramping, ${ }^{472}$ a caged rabbit within a meat farm would then be in relatively better conditions.

Welfare in the provision of euthanasia is another major inconsistency between industries. Take for example rabbits in the food industry, whereby the MCOPIHR recommends a rabbit be 'destroyed humanely by cervical dislocation' as opposed to the mandatory Code of Prac. Hsing Lab Mice, Rats, Guineas, Rabs., which states that neck dislocation is not acceptable and is regarded as inhumane. ${ }^{473}$

The concept of 'necessary suffering' under animal welfare legislation influences the structure of protection legislation and is highlighted by inconsistencies in the application of the animal welfare Acts. ${ }^{474}$ Where human interests necessitate some cruelty in the treatment of animals, such as intensively farming rabbits for meat, the provisions are legally sanctioned by excluding animals from the animal welfare acts and introducing MCOP as animal welfare instruments within the framework of animal protection as was discussed in Chapter Two.

Inconsistencies in the application of animal welfare legislation can consequentially physically or psychologically harm rabbits if the harm is necessary for human use, such as the inability to meet the animal's Five Freedom which underpins their welfare. The application of the MCOPIHR to the domestic rabbits in the caged meat industry and the effect of the provisions of the Five Freedoms on animal welfare protection will be subject to extensive analysis in the next chapter.

\subsection{Conclusions}

The main objective of the analysis in Chapter Three was to identify how the domestic rabbit under specific industries was regulated, and what animal welfare protection was afforded to them. Within the analysis, I investigated the statutes used to regulate specific domestic rabbit industries and their relationship to the animal welfare Acts. Through some examples, I identified some issues in the protection of rabbits, mainly the inconsistent nature of animal welfare legislation pertaining to the domestic rabbit and the contextinformed rather than species-specific laws which are framed to protect rabbits.

Animal welfare legislation, as analysed in this chapter, is written to protect human interests. The result is that a rabbit will fall under different protections under the law depending upon the owner's use and independent of the animal's intrinsic interests. The way in which the animal welfare Acts are framed are biased in favour of non-economic animals. ${ }^{475}$

Inconsistencies were firstly highlighted in the definition under which domestic rabbits fall within a specified industry. A rabbit is not specified as a companion animal in any of the animal welfare Acts examined, but rather falls under the vague definition of 'other' or 'mammal', vague definitions that do not allow the rabbit to assume a public role in society as a companion animal equal to the role of a dog or a cat for example. This is a reflection on the status of rabbits brought in from the first settlement in Australia and considered as 'pests' in all jurisdictions up to this day. Consequently, legislation has evolved around the eradication and the exploitation of this species for commercial purposes, as discussed earlier in this chapter.

A rabbit can be an 'abattoir animal: Rabbit', a 'stock animal', a 'specified animal: rabbit', etc. The adoption of different terms for a rabbit puts an economic value on the rabbit and determines their welfare protection depending on their use. Inconsistencies with the treatment of rabbits within animal welfare Acts are evident from their exclusions either directly or indirectly from some operations of the animal welfare Acts. A rabbit will be excluded from the application of the animal welfare Acts for example by providing that it is a defence to an allegation of cruelty that a behaviour towards an animal was conducted within a MCOP.

469 DEMELLO, M., Rabbits in Captivity, in Lori Gruen (ed), The Ethics of Captivity (Oxford University Press, 2014) 80.

470 CAULFIELD, M., Animals in Australia (Vivid Publishing, 2018) 234.

471 Department of Primary Industries (Vic) Code of Practice for the Housing and Care of Laboratory Mice, Rats, Guinea Pigs and Rabbits, 2004 (State of Victoria, 2004) 7.

472 O'SULLIVAN, S., Animals, Equality and Democracy (Palgrave MacMillan, 2011) 138

473 Department of Primary Industries (Vic) Code of Practice for the Housing and Care of Laboratory Mice, Rats, Guinea Pigs and Rabbits, 2004 (State of Victoria, 2004) 49.

474 O'SULLIVAN, S., Animals, Equality and Democracy (Palgrave MacMillan, 2011) 138.

475 Ibid 43. 
Identifying a rabbit, for example, as a 'stock animal' and applying the Model Code of Practice for the Welfare of Animals: Intensive husbandry of Animals is a legal loophole for raising and killing rabbits in ways which would be otherwise disallowed or considered inhumane.

Adopting a MCOP into legislation does not mean that an animal welfare Act does not apply, just that practices carried out in accordance with the MCOP will be immune from prosecution. Exemptions are therefore designed to allow people who keep animals for profit to keep them tightly confined as objects of production.

The animal welfare framework under which the domestic rabbit falls in the meat industry, as seen in the analysis of this chapter, encompasses two regimes: one during the rabbit's life on the farm and the other during slaughter. In the next chapter, those two regimes are expanded on and the conditions under which rabbits are raised and killed for food, through the application of the MCOPIHR and slaughter standards, are scrutinised. The MCOPIHR is evaluated against photographic data from intensive rabbit meat farms across several jurisdictions and its provisions assessed in practice. The Five Freedoms are also examined as the animal welfare concept underpinning some of the Australian national animal welfare bodies in order to identify the needs for reform.

\section{Chapter 4. Analysis of Welfare in the Australian Domestic Rabbit Meat Industry}

\subsection{Introduction}

As previously discussed, rabbits raised for food fall under two regimes of animal welfare: one during their life on a farm, and one during slaughter. The purpose of this chapter is to expand on the analysis of those welfare regimes, the Model Code of Practice for the Welfare of Animals: Intensive Husbandry of Rabbits (MCOPIHR) and Standards of slaughter and what they mean to the wellbeing of rabbits raised and killed for meat. The application of animal welfare through the MCOPIHR is evaluated against photographic data from intensive rabbit meat farms across several jurisdictions and its provisions assessed in practice. The Five Freedoms are also examined as the animal welfare concept underpinning some of the Australian national animal welfare bodies in order to identify the needs for reform.

The analysis presented in this chapter has three parts:

Firstly, to analyse the welfare of rabbits in practice within the intensive rabbit meat industry, the provisions of husbandry within the Model Code of Practice for the Welfare of Animals: Intensive Husbandry of Rabbits (MCOPIHR) are evaluated against the Five Freedoms of Animal Welfare. ${ }^{476}$ This is done to understand what constitutes animal welfare within the MCOPIHR and how this compares to the standards set by the Five Freedoms. The Five Freedoms are used as a reference tool as they are the foundation of Australian Animal Welfare and adopted by the two key animal welfare national bodies in Australia, the RSPCA ${ }^{477}$ and Animal Health Australia. ${ }^{478}$

The second part of the analysis involves assessing the effectiveness of the MCOPIHR by comparing its provisions to video footage and photographic data of rabbits inside Australian intensive rabbit meat farms. The footage and photographic data were taken in several farms in Victoria and Western Australia between 2010-2016. The fact that the footage was taken over several years and in two states, if not representative of general practice, strongly suggests issues that are having a significant impact on rabbit welfare. Details of footage and photographic data will be discussed in more detail in section 4.5.

The third part of the analysis provided involves a critique of the concept of animal welfare as it pertains to keeping rabbits in cages. This part of the chapter is informed by Bekoff and Pierce's work, which highlights the need to understand the ethology, rather than just the physiology, of species in order to understand their needs and wellbeing. ${ }^{479}$ This view contrasts with the approach taken by contemporary animal welfare science, which is driven by economic factors. ${ }^{480}$ The alternative to animal welfare, as developed by Bekoff and Pierce, which they term 'the Science of Animal Wellbeing', ${ }^{481}$ proposes the use of recent scientific knowledge in the study of animal ethology as the driver of animal protection. On this basis, I compare the effectiveness of the Five Freedoms, as the underpinning animal welfare concept in Australia, ${ }^{482}$ with scientific knowledge of rabbit biology and behaviour acquired within the last two decades as presented by the European Food and Safety

476 RSPCA, Five freedoms for animals (12 Jun 2009) <http://kb.rspca.org.au/five-freedoms-for-animals_318.html>.

477 Ibid.

478 Animal Health Australia, About Us (19 July 2018) <https://www.animalhealthaustralia.com.au/who-we-are/company-profile/>. 479 BEKOFF, M.- PIERCE, J., The Animals' Agenda: Freedom, Compassion and coexistence in the Human Age (Beacon Press, 2017) 29.

480 Ibid 24.

481 Ibid 29.

482 RSPCA, Five freedoms for animals (12 Jun 2009) <http://kb.rspca.org.au/five-freedoms-for-animals_318.html>.

148 Derecho Animal. Forum of Animal Law Studies, vol. 10/2 
Authority (EFSA) report, the Impact of the current housing and husbandry systems on the health and welfare of farmed domestic rabbits, ${ }^{483}$ and the ethological needs of rabbits as identified by the Dutch report Brief of Requirements of the Rabbit (BoR), which addresses rabbit ethology. ${ }^{484}$

\subsection{The Rabbit Meat Industry by Numbers - a Background}

As seen in Chapter Three, historically it was the use of wild rabbits in Australia which dominated the rabbit meat and fur industries. However, in 1996, after the Australian government released the Rabbit Calicivirus Disease (RCD) as a new biological control agent to kill wild rabbits, ${ }^{485}$ a large part of the wild rabbit population was wiped out. As a result, the estimated number of hunted wild rabbits dropped considerably (to around 100,000 per year). This coincided with a resurgence in interest in domestic rabbit farming in Australia. ${ }^{486}$

In 1999 the Commonwealth project 'Crusader' was established. Crusader was a collaborative research project between the Commonwealth Scientific and Industrial Research Organisation (CSIRO) and the Rural Industries Research and Development Corporation (RIRDC) that aimed to support the development of the intensive rabbit meat industry. ${ }^{487}$ The main objective was to develop a breeding program with the emphasis on improving rabbit genetic breeding traits related to intensive rabbit commercialisation profitability. ${ }^{488}$ By 2001 , an estimate of 250 CSIRO breeding rabbits were sold to rabbit farmers. ${ }^{489}$

In 2002, after the initial phase of Crusader was completed, 561 intensive rabbit commercial producers were estimated to be operating in Australia, 500 in New South Wales, 52 in Victoria, 6 in South Australia, and 3 in Western Australia. ${ }^{490}$ Also, in 2002, 21 farmed rabbit slaughterhouses were in operation, 9 in New South Wales, 6 in South Australia, 6 in Victoria, and 1 in Western Australia ${ }^{491}$ Over the period of 1998-2003, rabbit meat production in Australia grew an average of $10 \%$ per year. ${ }^{492}$ The projection for the industry in 2004 was that it would grow by $13 \%$ in the period $2004-2008$ followed by $8 \%$ growth up to $2015 .{ }^{493}$ However, by 2006-07, the number of intensive rabbit farms shrunk to 44 mainly due to disease problems and costly operations. $^{494}$

In 2011-12, rabbit meat production was down by $19 \%$ from 2006-07. ${ }^{495}$ At that time only 22 official rabbit meat producers remained in Australia. ${ }^{496}$ These were the larger farms with an estimated average number of 300 breeding does producing a total of 265 tonnes of rabbit meat per year. ${ }^{497}$ In 2014, there were less than 10 operating rabbit farms in Australia. ${ }^{498}$ The RIRDC five-year Research and Development Report Animal

483 Scientific Panel on Animal Health and Welfare, 'The Impact of the current housing and husbandry systems on the health and welfare of farmed domestic rabbits' (2005) 267 The EFSA Journal, 1-31.

484 CORNELISSEN, J.M.R. et al, Report 524: Brief of Requirements of the Rabbit (2011) Wageningen UR Livestock Research.

485 Note that by the late 1950s, resistance to the myxomatosis virus was starting to build up in Australia's rabbits. CSIRO, Case

Study: Controling those Pesky Rabbits <https://www.csiro.au/en/Research/BF/Areas/Invasive-species-and-diseases/Biologicalcontrol/Controlling-those-pesky-rabbits>.

486 It is estimated that the benefits to the agricultural industries of these two biocontrol viruses are about $\$ 70$ billion. CSIRO, Case Study: Controling those Pesky Rabbits <https://www.csiro.au/en/Research/BF/Areas/Invasive-species-and-diseases/Biologicalcontrol/Controlling-those-pesky-rabbits>.

487 EADY, S., Farmed Rabbits in Australia (2003) 02/144 Rural Industries Research and Development Corporation Publication, 146.

488 Ibid

489 WILLIAMS, S.- PATTINSON, R., Animal Industries Five Year RD\&E Plan 2013-2018 (2014) 14/055 Rural Industries Research and Development Corporation Publication, 5-6.

490 SHIM-PRYDON, G.- CAMACHO-BARRETO, R., New Animal Products New uses and markets for by-products and coproducts of crocodile, emu, goat, kangaroo and rabbit' (2007) 06/117 Rural Industries Research and Development Corporation Publication, 165.

491 FOSTER, M., Emerging animal and plant industries: their value to Australia (2014) 14/069 Rural Industries Research and Development Corporation Publication, 1-172.

492 GORDON, J.- GARRET, D., Rabbit farming: An evaluation of the Crusader R\&D program (2003) 03/144 Rural Industries Research and Development Corporation, 1-29.

493 Ibid.

494 FOSTER, M., Emerging animal and plant industries: their value to Australia (2014) 14/069 Rural Industries Research and Development Corporation Publication, 1-172.

495 Ibid.

496 TWOMEY, S., Farmed rabbit on the fall in Australia as producer numbers drop, The Weekly Times (online) 2014

$<$ http://www.weeklytimesnow.com.au/agribusiness/farmed-rabbit-on-the-fall-in-australia-as-producer-numbers-drop/ newsstory/0823d9540dce1951d15314622591d251>.

497 FOSTER, M., Emerging animal and plant industries: their value to Australia (2014) 14/069 Rural Industries Research and Development Corporation Publication, 1-172.

498 WILLIAMS, S.- PATTINSON, R., Animal Industries Five Year RD\&E Plan 2013-2018 (2014) 14/055 Rural Industries Research and Development Corporation Publication, 5-6. 
Industries - New, Developing and Maturing for the years 2013-2018, ${ }^{499}$ indicates that although the demand for domestic rabbit meat is good, the industry has negative growth prospects due to disease and welfare issues. ${ }^{500}$

\subsection{Commercial Rabbit Meat Farms: Industry Practice}

The scope of the Australian domestic rabbit meat industry ranges from large scale commercial rabbit meat farms and processors in which rabbits are caged, to small backyard farmers. ${ }^{501}$ In Australia, large scale commercial rabbit meat farming is an intensive caged indoor operation. ${ }^{502}$ The recommended industry practice is for rabbits to be confined to wire cages suspended above the floor. ${ }^{503}$

A doe $\mathrm{e}^{504}$ in the rabbit meat industry is expected to produce an average of eight litters per year consisting of around 40 weaners. ${ }^{505}$ The weaners are marketed for slaughter at the age of $11-13$ weeks, ${ }^{506}$ a small fraction of their expected lifespan of 8-12 years. ${ }^{507}$ According to the recommendations of the Department of Primary Industries, on average a doe should be culled after she has weaned seven litters approximately every 56 weeks. ${ }^{508}$

In breeding facilities and farms, does and bucks ${ }^{509}$ are kept in isolation in separate cages. One buck is made to mate with approximately 10 does. The doe is brought to the buck's cage by the farmer and then after mating, both are returned to isolation. ${ }^{510}$ Commercial rabbit breeders have become more dependent on Artificial Insemination (AI) Programmes. ${ }^{511}$ According to an ABC Landline interview with a large rabbit farm owner, one buck is typically used to inseminate 40 does through AI. ${ }^{512}$

When a doe has her litter, she is kept with the kittens for about four weeks until they have been weaned. ${ }^{513}$ The weaners are then transferred to another cage (they are now called grower or fattener rabbits) where they are kept for 11-13 weeks, until they are slaughtered (Fryers). Normally, if the mortality rate during fattening is high, the production phase will be shortened to around 10 weeks. ${ }^{514}$ The Grower rabbits are intensively reared during their average short lives of 12 weeks. They are provided with $0.07 \mathrm{~m}^{2}$ of space per rabbit, as recommended by the Model Code of Practice for the Welfare of Animals: Intensive Husbandry of Rabbits $^{515}$ (MCOPIHR), which is roughly the area of an A4 sheet of paper. To keep the operation of rearing meat rabbits profitable, rabbits are fed with least-cost diet pellets. ${ }^{516}$

\subsection{The Domestic Rabbit Meat Farm Welfare Regime}

The regulations under which rabbits fall as food animals and the adoption of standards and codes of practice into animal welfare Acts were discussed in Chapter Three for NSW, WA and Vic. This section expands on the Husbandry Codes of Practice and the Standards of slaughter as applied to the domestic rabbit in the meat industry in NSW, Vic and WA.

\section{Ibid.}

500 Ibid.

501 Farmstyle Australia, Farming Meat Rabbits: An Introduction <http://farmstyle.com.au/news/farming-meat-rabbits-introduction>. 502 TAYLOR, G.- KRUGER, I., Farming meat rabbits in NSW. Profitable and Sustainable Primary Industries (NSW Department of Primary Industries PRIMEFACT 104, 2004)1-5.

503 Ibid.

$504 \mathrm{~A}$ 'Doe' is a female rabbit.

$505 \mathrm{~A}$ 'Weaner' is a young rabbit that has been taken from their mother..

506 TAYLOR, G.- KRUGER, I., Farming meat rabbits in NSW. Profitable and Sustainable Primary Industries (NSW Department of Primary Industries PRIMEFACT 104, 2004)1-5.

507 Pet Med, How Long Will My Rabbit Live <https://www.petmd.com/rabbit/care/how-long-will-my-rabbit-live>.

508 TAYLOR, G.- KRUGER, I., Farming meat rabbits in NSW. Profitable and Sustainable Primary Industries (NSW Department of Primary Industries PRIMEFACT 104, 2004)1-5.

509 A 'Buck' is a male rabbit.

510 TAYLOR, G.- KRUGER, I., Farming meat rabbits in NSW. Profitable and Sustainable Primary Industries (NSW Department of Primary Industries PRIMEFACT 104, 2004)1-5.

511 STAIGHT, K., 'Breeding Rabbits', ABC Landline (online) 9 November $<$ http://www.abc.net.au/tv/programs/landline/old-site/ content/2008/s2736433.htm>.

512 Ibid

513 TAYLOR, G.- KRUGER, I., Farming meat rabbits in NSW. Profitable and Sustainable Primary Industries (NSW Department of Primary Industries PRIMEFACT 104, 2004)1-5.

514 LEBAS, F. et al, 'The rabbit husbandry, health and production' (1997) 21 Food and Agriculture Organisation of the United Nations.

515 CSIRO Publishing and Primary Industry Standing Committee (Cth), Model Code of Practice for the Welfare of Animals: Intensive Husbandry of Rabbits (Primary Industries Report Series 33, 2003).

516 TAYLOR, G.- KRUGER, I., Farming meat rabbits in NSW. Profitable and Sustainable Primary Industries (NSW Department of Primary Industries PRIMEFACT 104, 2004)1-5. 
The analysis in Chapter Three indicated that there are two separate welfare regimes for domestic rabbits. The first is the welfare which governs rabbits as animals raised for food within systems of confinement such as welfare within husbandry practices, and the second is the animal welfare which falls under the slaughter standards.

Taking rabbits raised and killed as food in NSW for example, legislation exempts rabbits from specific provisions under the Prevention of Cruelty to Animals Act 1979 (NSW) such as the need to exercise. ${ }^{517}$ This is by virtue of the rabbit falling under the definition of 'stock animal', ${ }^{518}$ or 'an animal of a species which is usually kept in captivity by means of a cage'. ${ }^{519}$

Rabbits raised for food can also be indirectly excluded from the operation of the Prevention of Cruelty to Animals Act 1979 (NSW) by compliance with the Model Code of Practice for Animal Welfare: Intensive Husbandry of Rabbits (MCOPIHR). Compliance with this Code can be submitted as evidence against a charge of animal cruelty. ${ }^{520}$ Table 3 in Chapter Three lists the legal status of the MCOPIHR within the states of NSW, Vic and WA and the consequence of their breach.

The exclusion of rabbits, as food animals, from the Prevention of Cruelty to Animals Act 1979 (NSW) section 24(1)(b)(ii) ${ }^{521}$ makes rabbits consumable animals for the purpose of the Food Act 2003 (NSW) and the Food Regulations 2015 (NSW). Further, the Australian Standard for the Hygienic Production and Transportation of Meat and Meat Products for Human Consumption (AS 4696:2007), as adopted under the Food Regulations 2015 (NSW), does not include in its scope abattoirs in which rabbits are slaughtered, ${ }^{522}$ except for Standard 16 part 6, which has no significance to animal welfare. ${ }^{523}$

Under regulation 83(1)(c) of the Food Regulations 2015 (NSW), the Australian Standard for Hygienic Production of Rabbit Meat for Human Consumption (AS 4466:1998) is adopted. Standard 11 provides that rabbits be restrained and stunned by humane methods. AS4466:1998 states that '[o]peration under this Standard implies compliance with relevant Model Codes of Practice for the Welfare of Animals' ${ }^{524}$ Therefore cervical dislocation is an acceptable method of killing. However, the lack of definition of 'humane' restraint and stunning within AS 4466:1998 and the voluntary nature of compliance with the Model Code of Practice for the Welfare of Animals: Intensive Husbandry of Rabbits, along with the slaughterhouse audits being performed by food hygiene inspectors rather than animal welfare enforcement agencies, means that the rabbit meat industry has largely self-regulated dominion over the pain and suffering to which rabbits are subjected.

The following two sections expand on the standards of slaughter and the Codes of Practice in intensive rabbit farms in NSW, Vic and WA and what their application means to rabbits raised and slaughtered for food.

\subsubsection{Standards of Slaughter}

The relevant laws governing slaughter of rabbits for human consumption in NSW, Vic and WA require compliance with the following two standards:

- AS 4466-1997: Hygienic production of rabbit meat for human consumption, ${ }^{525}$ or its more recent revision AS 4466-1998..$^{526}$

- AS 4696-2007: Hygienic production and transportation of meat and meat products for human consumption. ${ }^{527}$

Table 4 in Chapter Three presented the extent of the adoption of the standards of slaughter into legislation while Table 5 listed the animal welfare provisions included within the standards. This section extends the analysis of inconsistencies within the standards from the point of view of their application to the welfare of rabbits.

517 Section 9(1A) of the Prevention of Cruelty to Animals Act 1979 (NSW).

518Prevention of Cruelty to Animals Act 1979 (NSW) s 4 'Stock animal: 'which means an animal which belongs to the class of animals comprising cattle, horses, sheep, goats, deer, pigs, poultry and any other species of animal prescribed for the purposes of this definition'.

519 Prevention of Cruelty to Animals Act 1979 (NSW) s9(1A)(b).

520 Ibid s 34A(3).

521 Prevention of Cruelty to Animals Act 1979 (NSW) s 24(1)(b)(ii) 'destroying the animal, or preparing the animal for destruction, for the purpose of producing food for human consumption'.

522 Food Regulations 2015 (NSW) r83(1)(a).

523 Food Regulations 2015 (NSW) r83(2); Food Regulations 2015 (NSW) r83(3)

524 Australian Standard for Hygienic Production of Rabbit Meat for Human Consumption, SCARM Report 59, AS 4466:1998,1.

525 Australian Standard for Hygienic Production of Rabbit Meat for Human Consumption, SCARM Report 59, AS 4466:1997.

526 Australian Standard for Hygienic Production of Rabbit Meat for Human Consumption, SCARM Report 59, AS 4466:1998.

527 Australian Standard for the Hygienic Production of Meat and Meat Products for Human Consumption, FRSC Technical Report No. 3, AS 4696: 2007 
The desired outcome of animal welfare as listed in Part 7 of AS 4696::2007 is 'the minimisation of risk of injury, pain and suffering and the least practical disturbance to animals' ${ }^{528}$ Standard 7.4 says '[a]nimals are provided with feed (where appropriate), water, shade, shelter, space and ventilation that is sufficient to minimise stress to the animals ${ }^{3}{ }^{529}$ This is contrary to the specifications in standard 11.2 of the AS 4466:1997 and AS 4466:1998 which states that '[f]eed shall be withheld from rabbits for 24 hours prior to slaughter'. ${ }^{530}$ This conflicts with the scientific notion of animal welfare or minimisation of stress for rabbits according to veterinarians specialising in rabbits. Withholding feed from rabbits according to veterinarians will result in Gastro-Intestinal (GI) stasis and some liver damage. ${ }^{531}$ A rabbit can begin to suffer liver damage within a few hours once the GI tract is empty. Veterinarians therefore never advise fasting a rabbit, even prior to surgery. ${ }^{532}$ GI stasis causes extreme abdominal pain in rabbits. ${ }^{533}$ The slowdown of the normal intestinal movement often results in a painful death in a short period of time. ${ }^{534}$

Standard 7.9 in AS 4696:2007 describes slaughter requirements as '[a]nimals are slaughtered in a way that prevents unnecessary injury, pain and suffering to them and causes them the least practicable disturbance'. ${ }^{535}$ While standard 7.10 says ' $[\mathrm{b}]$ efore sticking commences, animals are stunned in a way that ensures the animals are unconscious and insensible to pain before sticking occurs and do not regain consciousness or sensibility before dying, ${ }^{536}$ Standard 11.4 in AS 4466:1997 and AS 4466:1998 require that restraining and stunning be done by an approved humane method prior to bleeding. ${ }^{537}$ Both standards define slaughter by "sticking, ${ }^{538}$ or 'bleeding ${ }^{539}$ however there is no definition of stunning procedures. Standard 11.4 in 4466:1997 and 4466:1998 includes the following reference to stunning: '[r]abbits to be restrained by an approved method and electrically stunned or made unconscious and insensible to pain by other approved humane methods prior to bleeding, ${ }^{540}$

The vague notion of stunning can potentially lead to the institution of practices that cause rabbits unnecessary harm and suffering, and thus amount to what would be an act of cruelty. This proposition is supported by the NSW Food Authority 2012 General Circular. ${ }^{511}$ However, the addition of the word 'humanely' implies that killing per se is not cruel and not subject to a breach of cruelty statutes. ${ }^{542}$

There is little consistency across jurisdictions with regards to animal welfare standards pertaining to rabbits before or during slaughter. This is reinforced by a 2010 research report by the RIRDC, ${ }^{543}$ which states that the standard of slaughter AS 4466:1998 has led to a variety of interpretation in procedures and processing methods between the food safety authorities in each state. ${ }^{544}$ The report highlighted that different states use different stunning methods for rabbits, ranging from operating completely without stunning, to other cases where rabbits are over stunned by hitting them against an object, causing blood clots and bruising. ${ }^{545}$ This is contrary to the requirements of the Standard which states '[o]peration under this Standard implies compliance with relevant Model Codes of Practice for the Welfare of Animals'. ${ }^{546}$ The Model Code of Practice for the Welfare of Animals: Intensive Husbandry of Rabbits, part 9 'Euthanasia' specifies 'cervical dislocation is an

\section{Ibid 21.}

529 Ibid.

530 AS 4466:1997 standard 11.2.Australian Standard for Hygienic Production of Rabbit Meat for Human Consumption, SCARM Report 59, AS 4466:1997.

531 KREMPELS, D., Pre- and Post-operative care of Rabbits (3 January 2011) University of Miami Department of Biology $<$ http://www.bio.miami.edu/hare/opcare.html $>$.

532 Ibid

533 KREMPELS, D., GastroIntestinal Stasis, The Silent Killer (June 2005) University of Miami Department of Biology $<$ http://www.bio.miami.edu/hare/ileus.html $>$.

534 Ibid.

535 Australian Standard for the Hygienic Production of Meat and Meat Products for Human Consumption, FRSC Technical Report No. 3, AS 4696: 2007, 21.

536 Standard 7.10 in AS 4696:2007. Australian Standard for the Hygienic Production of Meat and Meat Products for Human Consumption, FRSC Technical Report No. 3, AS 4696: 2007

537.AS 4466:1997 standard 11.4.

538 Sticking is defined as' severing of the large blood vessels to induce effective bleeding'. Australian Standard for the Hygienic Production of Meat and Meat Products for Human Consumption, FRSC Technical Report No. 3, AS 4696: 2007, 6.

539 Bleeding is defined as 'cutting the rabbit's throat in a manner that prevents contamination'. AS 4466:1997 standard 11.4.

540 Australian Standard for Hygienic Production of Rabbit Meat for Human Consumption, SCARM Report 59, AS 4466:1998, 16. 541 NSW Food Authority, 'Management responsibilities for animal welfare at poultry and rabbit abattoirs' General Circular (2012),13.

542 CAULFIELD, M., Handbook of Australian Animal Cruelty Law (Animals Australia, 2009) 141.

543 COWIE, M., Farmed Rabbit Processing - Improving returns (2010)09/168 Rural Industries Research and Development Corporation Publication, 1-5.

544 Ibid.

545 Ibid

546 Australian Standard for Hygienic Production of Rabbit Meat for Human Consumption, SCARM Report 59, AS 4466:1997,1.

152 Derecho Animal. Forum of Animal Law Studies, vol. 10/2 
acceptable method' ${ }^{547}$

Methods of Euthanasia, ${ }^{548}$ a document published in Australia by the Invasive Animals Cooperative Research Centre (CRC) in 2012, describes cervical dislocation as a method of stunning rabbits by separating the skull and the brain from the spinal cord with a pressure blow to the skull which causes the blood flow to the brain to be reduced eventually causing death. ${ }^{549}$ According to this document, studies have shown that following cervical dislocation, 13 seconds of consciousness may remain. ${ }^{550}$ This implies that stunning rabbits using cervical dislocation leads to some rabbits being bled alive. For rabbits heavier than $1 \mathrm{~kg}$, dislocation is accomplished by holding the rabbit upside down with the legs in one hand while stretching the head backwards until the dislocation is felt. ${ }^{51}$ The rabbit is then suspended by both legs while a sharp blow is directed behind the ears. In the absence of a sharp object for the blow, the rabbit may be picked up by the hind legs and swung against a hard surface such as a rock or post. ${ }^{52}$ This is contrary to the aforementioned standards of slaughter which define stunning as the procedure by which an animal is rendered unconscious before being bled to death, ${ }^{553}$ or ' $[\mathrm{t}]$ he procedure by which an animal is rendered unconscious and insensible to pain'.

\subsubsection{Codes of Practice for the Intensive Husbandry of Domestic Rabbits (NSW, Vic, WA)}

The Model Code of Practice for the welfare of Animals: Intensive Husbandry of Rabbits ${ }^{555}$ (MCOPIHR) is the Commonwealth Model Code of Practice relating to the welfare of rabbits in intensive farms. The MCOPIHR was endorsed by the Australian Agricultural Council (AAC) as a National code in 1989 and published in 1991 with no subsequent revisions. It is the development of husbandry practices in domestic rabbit farms which, according to the Commonwealth Department of the Environment, Water, Heritage and the Arts, has enabled the production of large quantities of meat and fur from the domestic rabbits industry. ${ }^{556}$

Western Australia and Victoria have chosen not to adopt the MCOPIHR and have created their own codes of practice for the husbandry and management of domestic-type rabbits. Western Australia's code for intensive husbandry of rabbits is the Code of Practice for Keeping of Rabbits in WA and is identical to the MCOPIHR ${ }^{557}$ The State of Victoria's Code of Practice for the Intensive Husbandry of Rabbits Vic ${ }^{558}$ is based on the MCOPIHR, with additions in husbandry practices such as recommendations to vaccinate rabbits against the Calici virus. ${ }^{559}$

Table 3 in Chapter Three lists the MCOPIHR and WA and Vic state specific Codes of Practice applicable to domestic rabbits in the meat (and fur) industries. It also identifies their legal status in NSW, Vic and WA. Appendix 3A lists the differences between the details of provisions of the three Codes of Practice.

To understand what constitutes animal welfare within the MCOPIHR and how it relates to the definition of animal welfare in Australia, the basic needs of a rabbit as listed in the MCOPIHR ${ }^{560}$ are compared with the Five Freedoms.

The Model Code of Practice for the Welfare of Animals: Intensive Husbandry of Rabbits (MCOPIHR) is 'intended as a guide for all persons responsible for the intensive husbandry of domestic-type rabbits for commercial purposes' ${ }^{561}$ It claims that ' $[t]$ he basic requirement for the welfare of rabbits is a husbandry system appropriate to their physiological and behavioural needs, ${ }^{562}$

Table 8 assesses the MCOPIHR against the equivalent animal welfare 'Freedom'. The basic

547 CSIRO Publishing and Primary Industry Standing Committee (Cth), Model Code of Practice for the Welfare of Animals: Intensive Husbandry of Rabbits (Primary Industries Report Series 33, 2003), 11.

548 Trudy Sharpe, 'Standard Operating Procedure GEN001: Methods of euthanasia' (2012) Invasive Animals CRC. 1-16, 13.

549 Ibid

550 Ibid.

551 Ibid.

552 Trudy Sharpe, 'Standard Operating Procedure GEN001: Methods of euthanasia' (2012) Invasive Animals CRC. 1-16, 13.

553 Australian Standard for Hygienic Production of Rabbit Meat for Human Consumption, SCARM Report 59, AS 4466:1997, 4. 554 Ibid 6.

555 CSIRO Publishing and Primary Industry Standing Committee (Cth), Model Code of Practice for the Welfare of Animals: Intensive Husbandry of Rabbits (Primary Industries Report Series 33, 2003).

556 Department of the Environment, Water, Heritage and the Arts, Threat abatement plan for competition and land degradation by rabbits $(2008)<\mathrm{http}: / /$ www.environment.gov.au/biodiversity/threatened/tap-approved.html $>$.

557 Department of Local Government and Regional Development (WA) The Code of practice for keeping of Rabbits in Western Australia, 2003 (State of Western Australia, 2003)

558 Department of Agriculture (Vic), Code of Practice for the Intensive Husbandry of Rabbits (State of Victoria).

559 Ibid.

560 CSIRO Publishing and Primary Industry Standing Committee (Cth), Model Code of Practice for the Welfare of Animals: Intensive Husbandry of Rabbits (Primary Industries Report Series 33, 2003) 1.

561 CSIRO Publishing and Primary Industry Standing Committee (Cth), Model Code of Practice for the Welfare of Animals: Intensive Husbandry of Rabbits (Primary Industries Report Series 33, 2003).

562 Ibid. 
requirements as listed within the MCOPIHR pertain to the period (i.e. farmed or slaughtered) and context in which rabbits are bred and kept, up to the point of slaughter.

\begin{tabular}{|l|l|}
\hline MCOPIHR & Five Freedoms \\
\hline Readily accessible food and water & $\begin{array}{l}\text { (F1): Freedom from Hunger and Thirst - by ready access to } \\
\text { fresh water and a diet to maintain full health and vigour. }\end{array}$ \\
\hline $\begin{array}{l}\text { Accommodation providing protection from the } \\
\text { elements and does not harm or cause undue discomfort }\end{array}$ & $\begin{array}{l}\text { (F2) Freedom from Discomfort - by providing an } \\
\text { appropriate environment including shelter and a } \\
\text { comfortable resting area. }\end{array}$ \\
\hline Rapid recognition and treatment of injury and disease & $\begin{array}{l}\text { (F3) Freedom from Pain, Injury or Disease - by prevention } \\
\text { or rapid diagnosis and treatment. }\end{array}$ \\
\hline $\begin{array}{l}\text { Freedom of movement to stand, stretch, turn around and } \\
\text { lie down; }\end{array}$ & $\begin{array}{l}\text { (F4) Freedom to Express Normal Behaviour - by providing } \\
\text { sufficient space, proper facilities and company of the } \\
\text { animal's own kind. }\end{array}$ \\
\hline The MCOPIHR does not cover this Freedom & $\begin{array}{l}\text { (F5) Freedom from Fear and Distress - by ensuring } \\
\text { conditions and treatment which avoid mental suffering. }\end{array}$ \\
\hline
\end{tabular}

Table (8) MCOPIHR assessed against the equivalent animal welfare 'Freedom'.

Table 8 indicates that the MCOPIHR integrates four out of the Five Freedoms. For example, there exists a provision for food and water within the MCOPIHR, and the First Freedom of welfare is the' Freedom from Hunger and Thirst'. There is a basic requirement in the MCOPIHR for the rapid recognition and treatment of injury and disease, which is equivalent to the Third Freedom 'Freedom from Pain, Injury or Disease', and so on. For a more detailed summary of the MCOPIHR, see Appendix 3A.

Although the MCOPIHR claims that ' $[\mathrm{t}]$ he basic requirement for the welfare of rabbits is a husbandry system appropriate to their physiological and behavioural needs, ${ }^{563}$ it has no provision for ensuring behavioural conditions that avoid mental suffering as compared to the provision of the Fifth Freedom. The Victorian State Code of Practice for the Intensive Husbandry of Rabbits Vic has added a basic provision to the MCOPIHR's list which states '[e]nvironment permitting a level of social interaction so that individually housed rabbits can see and are aware of other rabbits' ${ }^{564}$ On the surface, this could be regarded as an additional animal welfare provision which could reduce mental suffering, as rabbits are social animals and require company of their own ${ }^{565}$ however, as the definition of intensive farms suggests, the close proximity to each other already provides the awareness of existence of other rabbits. The issue is that they are 'individually housed', which is an added stressor according to a scientific report on the behaviour and ethology of rabbits within intensive farm systems. ${ }^{566}$ Therefore, the provision as added by the State of Victoria for the environment amelioration is not based on the behavioural needs of rabbits as indicated by the science of rabbit behaviour and ethology. ${ }^{567}$ The difference in animal welfare provisions as to what rabbits need or want will be subject to discussion in the next two sections when ethological studies will be brought in to assess current animal welfare practice pertaining to rabbits caged in the meat industry.

It therefore appears from Table 8 that the MCOPIHR, along with the State Codes of Practice of husbandry in intensive rabbit farms in WA and Vic, have basic provisions of animal welfare which relate to the Five Freedoms while 'working within the constraints of an effective livestock industry' as defined by the RSPCA in their statement on animal welfare. ${ }^{568}$

The following section expands on the analysis of the MCOPIHR as an animal welfare tool in practice by comparing its provisions to observational data in the form of footage from Australian intensive rabbit meat farms in WA and Vic to examine whether the rabbits' welfare can be achieved in practice under this Code of Practice.

\subsection{Analysis of Welfare in Practice}

The following section investigates the effectiveness of welfare as a protection framework for rabbits in

563 CSIRO Publishing and Primary Industry Standing Committee (Cth), Model Code of Practice for the Welfare of Animals: Intensive Husbandry of Rabbits (Primary Industries Report Series 33, 2003), Introduction.

564 Department of Agriculture (Vic), Code of Practice for the Intensive Husbandry of Rabbits (State of Victoria).

565 Scientific Panel on Animal Health and Welfare, 'The Impact of the current housing and husbandry systems on the health and welfare of farmed domestic rabbits' (2005) 267 The EFSA Journal, 12.

566 CORNELISSEN, J.M.R. et al, Report 524: Brief of Requirements of the Rabbit (2011) Wageningen UR Livestock Research 16. 567 Ibid.

568 RSPCA, Five freedoms for animals (12 Jun 2009) <http://kb.rspca.org.au/five-freedoms-for-animals_318.html>.

154 Derecho Animal. Forum of Animal Law Studies, vol. 10/2 
meat farms. The analysis is divided into two sections.

Section 4.5.1 compares observational data in the form of video footage and photographic data from Australian intensive rabbit meat farms with the provisions of the Model Code of Practice for the Welfare of Animals: Intensive Husbandry of Rabbits to examine whether the rabbit's welfare is achieved in practice.

Background to the data to be analysed:

The footage is based on several undercover investigations by animal rights groups undertaken between 2010-16. Two of Australia's largest rabbit meat farms in the states of WA and Vic are included in the footage, as well as two smaller scaled farms in Victoria. No footage was available from NSW. For the purpose of anonymity none of the farms have been named. The footage analysed has been published on websites available to the public and the organisations who have published the footage are 'Aussie Farms' and 'Freedom for Farmed Rabbits'.

Aussie Farms, an animal rights charity and the directors of the animal rights documentary 'Dominion' ${ }^{569}$ provide video footage and photographic data in a public repository called 'the Aussie Farms Repository'. The aim of the repository is to increase industry transparency and educate the public about modern farming and slaughtering practices. ${ }^{570}$ The charity includes the following statement on their website:

'[t]he Aussie Farms Repository is a public repository/gallery for videos, photos, documents and campaign materials (fliers, posters, etc); a knowledgebase; and a centre for innovative and creative tools, relating to the animal rights movement in Australia'. ${ }^{571}$

'[a]nything that gets uploaded, unless it comes from a reputable organisation such as the various Animal Liberation groups, will be screened by the Aussie Farms Repository team before being published to ensure nothing malicious, deceptive or irrelevant slips through the cracks' ${ }^{572}$

Freedom for Farmed Rabbits, a registered charity in Australia, is an animal rescue centre. The organisation has been investigating rabbit farms since the early $2000 \mathrm{~s} .{ }^{573}$ Freedom for Farmed Rabbits have provided all photographic material from their investigations to the public via their website. ${ }^{574}$

In 2016 Channel Seven Television broadcasted footage of rabbit farms in Western Australia and the state of Tasmania obtained by Aussie Farms and Animal Liberation NSW. ${ }^{575}$ The event prompted Alex Greenwich, the then Member for Sydney in the NSW parliament, to speak in favour of the introduction of a Bill to Parliament with the purpose of banning rabbit meat farms on the basis of animal cruelty in the industry. ${ }^{576}$ In personal correspondence with the author Mr Greenwich stated that the Bill would ban the keeping of rabbits for the purpose of commercial production of meat, fur or angora in NSW. ${ }^{577}$

The footage aired on television was also discussed in Parliament. However, it was dismissed as a oneoff incident and a 'misguided campaign by animal rights activists. ${ }^{578}$ The following is an excerpt of the relevant Parliamentary debate:

'[i]n this country there are laws and legal processes governing animal cruelty, as well as a range of strong animal welfare codes of practice. There are also proper channels through which to take action, not some scratchy, undated footage collected in secret that is purely aimed at drawing emotional responses from a largely unprepared and unknowing general audience. It is important that as passionate advocates for country people we call out activists who do the wrong thing, and we highlight good animal husbandry and proper processes and practices'. ${ }^{579}$

In light of this parliamentary discussion and to properly assess animal welfare in practice, I have chosen multiple sources of evidence and a bounded system in keeping with the requirements of a case study

569 IMBD, Dominion < https://www.imdb.com/title/tt5773402/>.

570 Aussie Farms, The Aussie Farm Repository $<$ https://www.aussiefarms.org.au/about>.

571 Aussie Farms, The Aussie Farms Repository <https://www.aussiefarms.org.au>.

572 Ibid.

573 Freedom for Farmed Rabbits Inc., Cruelty Evidence $(2018)<$ http://www.freedomforfarmedrabbits.com.au/farms/crueltyevidence/>.

574 Ibid.

575 Aussie Farms, Baldivis Rabbits (2016) < https://www.aussiefarms.org.au/facilities/da16d-baldivis-rabbits>.

576 Alex Greenwich Independent Member For Sydney, Rabbit Cruelty (2016) <http://www.alexgreenwich.com/rabbit_cruelty>.

577 Email from Tammie Nardone to Author, 10 July 2018.

578 New South Wales, Parliamentary Debates, Legislative Council, 20 September 2016, 1224 (MELINDA PAVEY)

$<$ https://www.parliament.nsw.gov.au/Hansard/Pages/HansardResult.aspx\#/docid/HANSARD-1323879322-93143>.

579New South Wales, Parliamentary Debates, Legislative Council, 20 September 2016, 1224 (MELINDA PAVEY)

$<$ https://www.parliament.nsw.gov.au/Hansard/Pages/HansardResult.aspx\#/docid/HANSARD-1323879322-93143>. 
approach. ${ }^{580}$ The analysis is bounded by jurisdiction, that is the states of Vic and WA, observational data, by choosing several farms to analyse, and the timeline: between the years 2010-16. At the end of the analysis I have also included the two-minute Channel Seven television broadcast ${ }^{581}$ as discussed in NSW Parliament, as arguably the video footage raises the existence of substantive issues of cruelty within this industry, including farms in Western Australia and Tasmania.

A rabbit meat farm in WA has been included within the analyses. However, the Tasmanian farm has been excluded as the jurisdiction does not fall under the scope of this research. The analysis of footage in section 4.5.1 of current husbandry, health and animal welfare issues is compared against scientific analyses of rabbit husbandry systems such as the EFSA's report, The Impact of the current housing and husbandry systems on the health and welfare of farmed domestic rabbits. ${ }^{52}$ The EFSA report provides a useful reference point to whether, biologically and behaviourally, the adequate standards of rabbit welfare is achieved in practice.

Section 4.5.2 asks whether the Five Freedoms as a welfare concept can be met within the rabbit caged industry. In other words, how effective are the Five Freedoms in providing wellbeing to rabbits within cages. The Five Freedoms are compared to current animal welfare practices, industry recommendations, and the photographic data and video footage. The question posed for the purpose of analysis is whether each of the Freedoms is an achievable goal, or whether the concept of animal welfare in the caged rabbit meat industry is in effect an oxymoron as posed by this thesis.

In section 4.5.2, I draw on the 'Science of Wellbeing' approach advocated by Marc Bekoff and Jessica Pierce $^{583}$ to analyse what animal welfare means in terms of the wellbeing of rabbits bred and raised on meat farms. For this, I refer to ethological studies on the rabbit as identified by the Dutch report Brief of Requirements of Rabbits (BoR). ${ }^{584}$

\subsubsection{Analysis of the Welfare of Rabbits on Meat Farms from Observational Data}

This section examines how the welfare of rabbits on meat farms plays out in practice compared to the husbandry conditions recommended in the Model Code of Practice for the Welfare of Animals: Intensive Husbandry of Rabbit (MCOPIHR). ${ }^{585}$ I draw on several publications from specialised veterinary and animal welfare scientists within the rabbit meat industry and the EFSA's report the Impact of the current housing and husbandry systems on the health and welfare of farmed domestic rabbits as a cornerstone for analysis. The EFSA report is used as it has been written to assess different husbandry conditions in intensive rabbit meat farms within the EU with the purpose of improving animal welfare conditions for rabbits. ${ }^{586}$ Key points from the EFSA report are listed in Appendix 3B.

The Western Australian and Victorian husbandry codes of practice for rabbit farms are based on the MCOPIHR. As the Victoria-specific Rabbit Husbandry Code of Practice, Code of Practice for the Intensive Husbandry of Rabbits $\mathrm{Vic}^{587}$ has some additional provisions of husbandry, which will be referenced where applicable for comparison.

As described in section 4.5, footage is sourced from two publicly available sources. The analysis of footage set out below is discussed under sections relating to the basic requirements of the rabbit's welfare as listed in the MCOPIHR. Those are: ${ }^{588}$

1. Accommodation providing protection from the elements and does not harm or cause undue discomfort;

2. Freedom of movement to stand, stretch, turn around and lie down;

3. Readily accessible food and water; and

580 HARRISON, H. et al, 'Case Study Research: Foundations and Methodological Orientations' (2017) 18(1) Qualitative Social Research Forum 13.

581 Aussie Farms, Baldivis Rabbits (2016) < https://www.aussiefarms.org.au/facilities/da16d-baldivis-rabbits>.

582 Scientific Panel on Animal Health and Welfare, 'The Impact of the current housing and husbandry systems on the health and welfare of farmed domestic rabbits' (2005) 267 The EFSA Journal, 1-31.

583 BEKOFF, M.- PIERCE, J., The Animals' Agenda: Freedom, Compassion and coexistence in the Human Age (Beacon Press, 2017) 24.

584 CORNELISSEN, J.M.R. et al, Report 524: Brief of Requirements of the Rabbit (2011) Wageningen UR Livestock Research. 585 CSIRO Publishing and Primary Industry Standing Committee (Cth), Model Code of Practice for the Welfare of Animals: Intensive Husbandry of Rabbits (Primary Industries Report Series 33, 2003).

586 ECK, S., Report on minimum standards for the protection of farm rabbits (2017) A8-0011/2017 European Parliament Plenary Sitting.

587 Department of Agriculture (Vic), Code of Practice for the Intensive Husbandry of Rabbits (State of Victoria).

588 CSIRO Publishing and Primary Industry Standing Committee (Cth), Model Code of Practice for the Welfare of Animals: Intensive Husbandry of Rabbits (Primary Industries Report Series 33, 2003), 1.

156 Derecho Animal. Forum of Animal Law Studies, vol. 10/2 
4. Rapid recognition and treatment of injury and disease.

\section{Provision 1: 'Accommodation providing protection from the elements and does not harm or cause undue discomfort';}

Analysis of footage from farms in Victoria and Western Australia found a lack of separate areas for rabbits to hide or retreat. ${ }^{589}$ The EFSA recommend the environment be subdivided by partitions in such a way that each animal is able to initiate or to avoid social contact and retreat and hide from potential danger. ${ }^{590}$

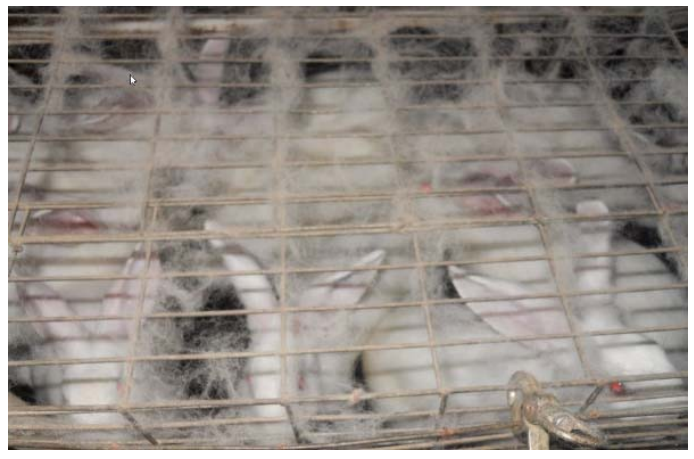

Figure 4 Overcrowding in a Victorian rabbit meat farm. ${ }^{591}$

Undercover Investigators have reported on various noise and light stressors in Farms. The following is a transcript from the video footage:

'Loud music played inside the sheds - I think it was used to mask outside noises frightening the rabbits who would try and jump in their small cages in an attempt to flee. However, the music seemed to cause more stress - I imagine they struggled to sleep with the constant noise and light'. ${ }^{592}$

Noise stressors can negatively affect a rabbit's nervous system. This can lead to startled responses resulting in traumatic injuries to limbs and back, exacerbated by the short cages where the rabbit cannot stand vigilant, hide or run for cover. ${ }^{593}$ The Code of Practice for the Intensive Husbandry of Rabbits Vic recommends a standard 15 hour daylight period to be maintained by the facility, ${ }^{594}$ although rabbits are crepuscular by nature which means they are most active during dusk and dawn and in the evening and remain in the darkness of their warrens most of the other times. ${ }^{595}$

Photographic evidence shows a lack of visual covers from above and behind the rabbits which would serve as shields from elements and predators. The lack of such covers is thought to cause rabbits stress. ${ }^{596}$ Rabbits startle when they suddenly see people or other animals. ${ }^{597}$ The EFSA report recommends rabbits should be provided an area to withdraw and hide from sources of potential danger. ${ }^{598}$

Photographic evidence also shows a lack of hygiene with masses of faecal matter piled up under the cages. Manure production from rabbits is about $153 \mathrm{~kg}$ of faeces plus urine per day for a 100-doe rabbit farm. ${ }^{599}$ In meat farms, urine and manure pile up under the living areas of the confined rabbits. There is no run off and no separation of areas for rabbits to use as a litter. The following is a transcript from undercover

589 Scientific Panel on Animal Health and Welfare, 'The Impact of the current housing and husbandry systems on the health and welfare of farmed domestic rabbits' (2005) 267 The EFSA Journal, 15.

590 Ibid.

591 Freedom for Farmed Rabbits Inc., Cruelty Evidence (2018) < http://www.freedomforfarmedrabbits.com.au/farms/crueltyevidence $/>$.

592 Animal Liberation NSW, Rabbits (2017) <https://www.animal-lib.org.au/campaigns/animals-forfood/rabbits>.

593 CARENZI, C., Animal welfare: review of the scientific concept and definition (2009) 8(1) Ital.J.Anim.Sci., 21-30.

594 Department of Agriculture (Vic), Code of Practice for the Intensive Husbandry of Rabbits (State of Victoria).

595 Joseph A. CHAPMAN, J.A.- FLUX, J.E.C., Rabbits, Hares and Pikas: Status Survey and Conservation Action Plan (International Union for Conservation of Nature and Natural Resources, 1990) 2.

596 VERGA, M., Intensive rabbit breeding and welfare: development of research, trends and applications (2000) Proceedings of the 7th World Rabbit Congress, 491-506.

597 MARAI, I.M.- RASHWAN, A.A., Rabbits behavioural response to climatic and managerial conditions - a review (2004) 47 (5) Arch. Tierz. Dummerstorf, 469-482.

598 Scientific Panel on Animal Health and Welfare, 'The Impact of the current housing and husbandry systems on the health and welfare of farmed domestic rabbits' (2005) 267 The EFSA Journal, 15.

599 TAYLOR, G.- KRUGER, I., Farming meat rabbits in NSW. Profitable and Sustainable Primary Industries (NSW Department of Primary Industries PRIMEFACT 104, 2004) 1-5. 
investigators:

'Under the cages masses of fur and faecal matter were in huge piles. They were covered in insects that were also eating rabbits who had died inside cages'. ${ }^{600}$

Poor ventilation in the sheds, increases in relative humidity, and poor hygiene all contribute to elevated concentrations of ammonia which can irritate the respiratory tract and increase the susceptibility of animals to respiratory disease.$^{601}$ The following is an undercover investigator's account of the environment in one of the farms:

'I recall being taken back by the smell of the place - it was like a burning ammonia smell that made my eyes water. These places are smelly, dirty, and dusty - I wanted to leave immediately. I can't imagine how horrible it must be for these animals to live there every day'. ${ }^{602}$

\section{Provision 2: 'Freedom of movement to stand, stretch, turn around and lie down';}

Analysis of footage from farms in Victoria and Western Australia found a lack of space to run and perform natural behaviour. A space slightly larger than an A4 page is provided per grower rabbit as recommended by the MCOPIHR. ${ }^{603}$ The following is an undercover investigator's account of space and environment in one of the largest meat farms in Australia:

'Severe overcrowding was an obvious issue - the rabbits could hardly move. The cages themselves were barren; no bedding was given to the rabbits being grown for their meat'. ${ }^{604}$

According to the EFSA, keeping animals in overly-confined conditions causes suffering. ${ }^{605}$ Based on behavioural studies, lower space allowances carry the risk of poor animal welfare because of the reduced functional space, the risk of overcrowding and inability to carry out certain behaviours. ${ }^{606}$ For example, as rabbits thermoregulate by stretching out, more space is needed to permit that behaviour when the ventilation system does not maintain suitable ambient conditions. ${ }^{607}$

A lack of provision of an area in which a medium sized rabbit can sit up normally with ears erect. ${ }^{608}$ The latter is thought to be an innate mechanism exhibited by rabbits in the wild both inside and outside the burrow in terms of their survival. ${ }^{609} \mathrm{~A}$ cage height of 45 centimetres is recommended by the MCOPIHR ${ }^{610}$ for a New Zealand White Rabbit. New Zealand rabbits of 12 weeks and over are, on average, about $55-70 \mathrm{~cm}$ tall when sitting in the typical lookout or alert posture with ears pricked up ${ }^{611}$ and approximately $80 \mathrm{~cm}$ long when resting in typical lateral position. ${ }^{612}$ This restrictive arrangement is likely to be particularly harmful for fully grown adult rabbits kept for breeding.

600 Animal Liberation NSW, Rabbits (2017) <https://www.animal-lib.org.au/campaigns/animals-forfood/rabbits>.

601 Department of Primary Industries (Vic) Code of Practice for the Housing and Care of Laboratory Mice, Rats, Guinea Pigs and Rabbits, 2004 (State of Victoria, 2004) 25-26.

602 Animal Liberation NSW, Rabbits (2017) <https://www.animal-lib.org.au/campaigns/animals-forfood/rabbits>.

603 CSIRO Publishing and Primary Industry Standing Committee (Cth), Model Code of Practice for the Welfare of Animals: Intensive Husbandry of Rabbits (Primary Industries Report Series 33, 2003), 4.

604 Animal Liberation NSW, Rabbits (2017) <https://www.animal-lib.org.au/campaigns/animals-forfood/rabbits>.

605 Scientific Panel on Animal Health and Welfare, 'The Impact of the current housing and husbandry systems on the health and welfare of farmed domestic rabbits' (2005) 267 The EFSA Journal, 14.

606 Ibid 12.

607 Ibid.

608 Ibid 15.

609 SLOOTEN, L., Design for the well-being of rabbits (Master's Thesis, Delft University of Technology, 2014) 90.

610 CSIRO Publishing and Primary Industry Standing Committee (Cth), Model Code of Practice for the Welfare of Animals: Intensive Husbandry of Rabbits (Primary Industries Report Series 33, 2003), 4.

611 OLAWUMI, S., Comparative Study on Rabbit Breeds for Post Weaning Growth Traits in the Humid Tropics of Nigeria (2014) 2(1) Global Journal of Animal Scientific Research, 45-51.

612 BOERS K. et al, Comfortable Quarters for Rabbits in Research Institutions. Animal Care Centre (2009) University of British Columbia, Vancouver BC, Canada, (Online) $<$ http://brighteyessanctuary.org/educ/comfylabrabbits.pdf. 


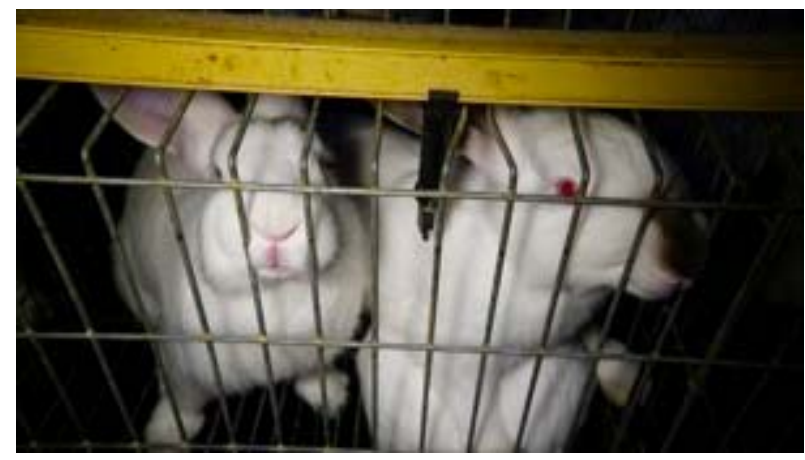

Figure 5 Lack of space to stand or erect their ears. ${ }^{613}$

The EFSA has found that it may be important for growing rabbits to be able to sit and stand with their ears erect, and occasionally to rear up, as these are evolutionary behaviours to increase the rabbits' field of vision on arousal and facilitate thermoregulation. ${ }^{614}$

\section{Provision 3: 'Readily accessible food and water';}

Analysis of footage from farms in Victoria and Western Australia found evidence of dirty drinkers and lack of, or inaccessibility to, food or drink due to overcrowding.

It should be noted here that where a lack of feed and water has been found, which is a clear breach under the provisions of the MCOPIHR, the breach does not necessarily amount to cruelty under animal protection laws, as the MCOPIHR or the equivalent Codes of Practice in WA and Vic are voluntary codes under the law.

\section{Provision 4: 'Rapid recognition and treatment of injury and disease';}

Analysis of footage from farms in Victoria and Western Australia found an absence of objects to gnaw (straw, grass, sticks) which inevitably results in overgrown teeth (Malocclusion), ${ }^{615}$ a condition which leads to anorexia due to the inability to feed. ${ }^{616}$

Inappropriate floor types within farms have been found to be the probable cause of splay legs, sore hocks and injuries to paws as observed by investigators:

'Some rabbits really struggled with the wire flooring. Filming from underneath I could see how much the mesh pushed into the bottom of their feet. Some of the kittens actually became stuck in the wire mesh and their little feet slipped through the holes'. ${ }^{617}$

The EFSA has observed that under commercial conditions the incidence of sore hocks (footpad lesions) from wire flooring can be quite high and is the third most common reason for culling rabbits. ${ }^{618}$

613 Aussie Farms, The Aussie Farms Repository (2014) <https:/www.aussiefarms.org.au/facilities/food/rabbits>

614 Scientific Panel on Animal Health and Welfare, 'The Impact of the current housing and husbandry systems on the health and welfare of farmed domestic rabbits' (2005) 267 The EFSA Journal, 13.

615 VERGA, M., Intensive rabbit breeding and welfare: development of research, trends and applications (2000) Proceedings of the 7th World Rabbit Congress, 491-506.

616 Vetstream, Dental malocclusion - overgrowth (2017) <https://www.vetstream.com/treat/lapis/ freeform/dental-malocclusionovergrowth>.

617 Animal Liberation NSW, Rabbits (2017) <https://www.animal-lib.org.au/campaigns/animals-forfood/rabbits>.

618 Scientific Panel on Animal Health and Welfare, 'The Impact of the current housing and husbandry systems on the health and welfare of farmed domestic rabbits' (2005) 267 The EFSA Journal, 9. 

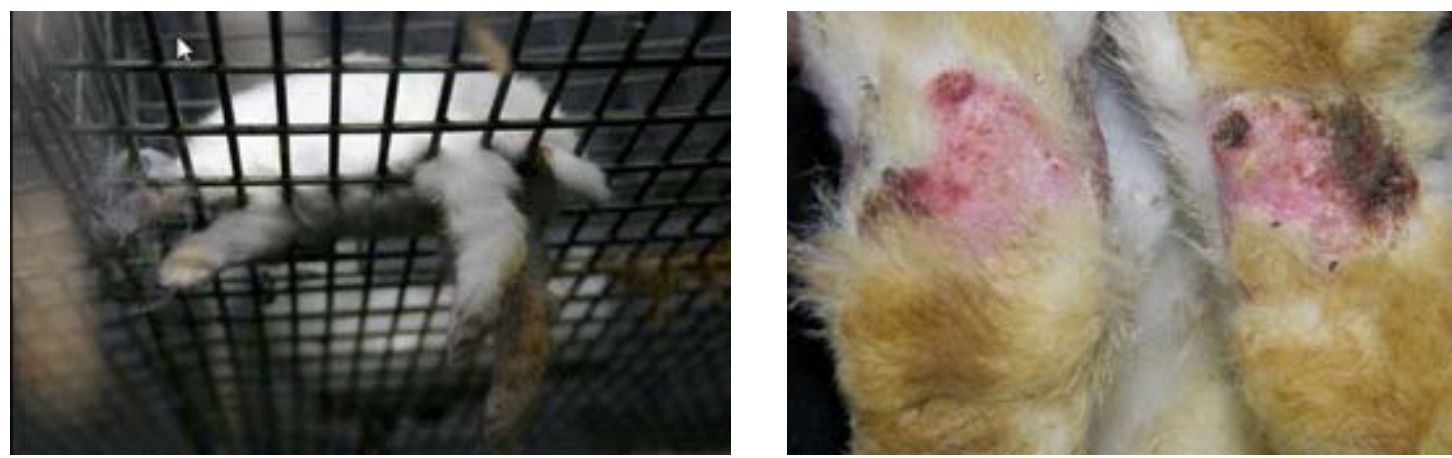

Figure 6 Injuries from wire cage designs ${ }^{619}$

The Lack of inspection and treatment of injuries and diseases and the removal of the deceased has been reported by investigators:

'I saw several rabbits with overgrown toe nails that had not been trimmed. These rabbits appeared to struggle on the wire mesh caging as their nails wrapped around the wire flooring making movement difficult'. ${ }^{620}$

Other indications of untreated injuries and diseases include: Mastitis from over breeding and the lack of hygienic conditions; Head Tilt, a common neurological condition brought about by stress; ${ }^{621}$ death from Coccidia diarrhoea, a highly contagious disease common on meat farms; ${ }^{622}$ common eye injuries and infections; evidence of vectors which carry diseases; insects feasting on dead rabbits and dead rats on the cages; and aggressive behaviour due to forced mating and over-crowding. This can result in injuries, biting, abscesses, lacerations, damage to eyes and ears and general mutilation. ${ }^{623}$

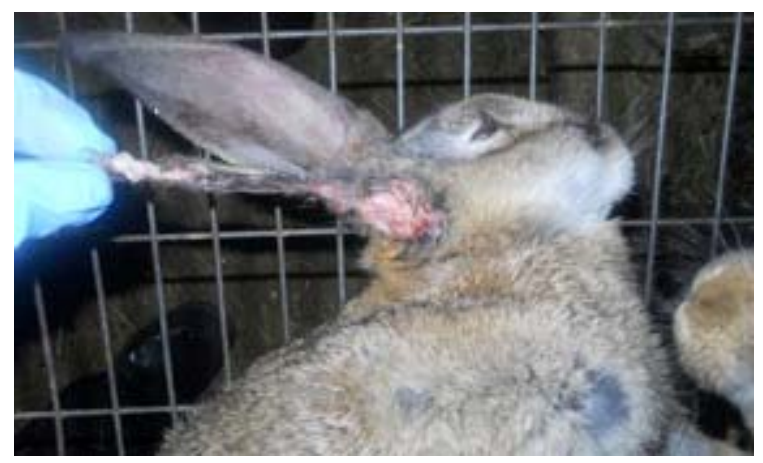

Figure 7 Result of aggression from close proximity in cages or forced mating. ${ }^{624}$

Additional abnormal behaviours have been reported and can be seen in the footage such as wiregnawing and pawing at corners. Abnormal behaviours are usually associated with the lack of any stimulation in the environment. ${ }^{625}$

619 Freedom for Farmed Rabbits Inc., Rabbit Farming (2018) < http://www.freedomforfarmedrabbits.com.au/farms/crueltyevidence/>.

620 Animal Liberation NSW, Rabbits (2017) <https://www.animal-lib.org.au/campaigns/animals-forfood/rabbits>.

621 OGLESBEE, B., Blackwell's Five-Minute Veterinary Consult: Small Mammal (John Wiley \& Sons, 2nd Ed 2011).

622 CSIRO, Crusader Meat Rabbit - Disease Tool Kit (2004) <https://publications.csiro.au/rpr/ download?pid=procite:520694e845f6-4a05-b87b-2104344dd5d0\&dsid=DS1>.

623 CORNELISSEN, J.M.R. et al, Report 524: Brief of Requirements of the Rabbit (2011) Wageningen UR Livestock Research, 23.

624 Freedom for Farmed Rabbits Inc., Cruelty Evidence $(2018)<$ http://www.freedomforfarmedrabbits.com.au/farms/crueltyevidence/>.

625 VERGA, M., Intensive rabbit breeding and welfare: development of research, trends and applications (2000) Proceedings of the 7th World Rabbit Congress, 491-506. 


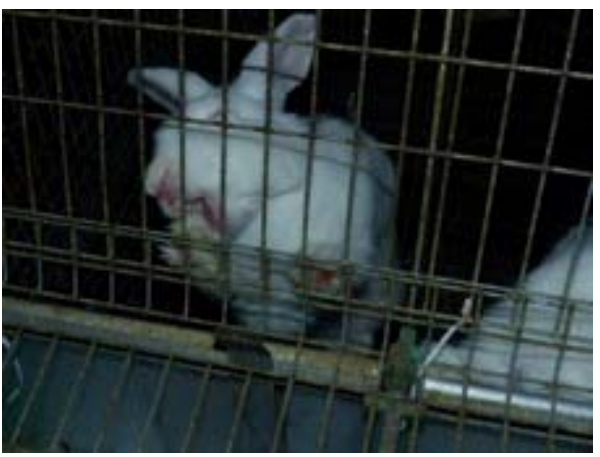

Figure 8 Signs of abnormal behaviour: Wire-gnawing and pawing. ${ }^{626}$

Disturbed maternal behaviour and care such as nursing, ${ }^{627}$ with the lack of possibilities of natural nesting behaviour and proper care of kittens by does.

The section above provided photographic evidence of common practices on rabbit meat farms in Victoria and Western Australia between the years 2010-2016 and their outcome on standards of rabbit welfare. While some footage shows a lack of compliance with provisions within the MCOPIHR, such as the 'rapid recognition and treatment of injury and disease', the MCOPIHR includes a statement that ailing rabbits 'should be humanely destroyed'. ${ }^{628}$ Therefore the life of the rabbit on a farm is a lottery dependent on the obligation or degree of duty of care of the farmer.

It is noteworthy that the diseases and injuries observed throughout the analysis of footage are the most common diseases known to affect farmed rabbits, as listed in the Crusader Meat Rabbit Disease Tool Kit. ${ }^{629}$ The toolkit contains many of those ailments, along with their causes, treatment and prevention, and has been distributed out to rabbit farmers on Crusader field days, workshops and industry meetings. ${ }^{630}$

The provision of 'space requirements' states that ' $[t]$ he floor area provided for the rabbits should be sufficient to allow the rabbits to move around, to feed and drink without difficulty, and to lie on their sides'. The MCOPIHR details of floor space recommend $0.07 \mathrm{~m}^{2}$ per rabbit for rabbits $5-12$ weeks ${ }^{631}$ which means that over-crowdedness is permitted under the MCOPIHR. It follows from this that the practices observed, such as dense packing leading to aggression or lack of ability to reach food and water, or to move or lie down, are a direct result of application of space provisions listed within the MCOPIHR. ${ }^{632}$ Although the lack of space to move and perform natural behaviour is evident from footage, such husbandry conditions would not constitute a breach of animal welfare or an act of cruelty under the law. As the MCOPIHR and its equivalent codes of practice in WA and Vic are voluntary, in case of a charge of animal cruelty, the codes may be submitted as defence in $\mathrm{WA}^{633}$ and $\mathrm{Vic}^{634}$ to 'unnecessary harm or suffering', or as evidence of compliance with the code and industry practices in NSW. ${ }^{635}$

There are clear conditions of injuries and distress amongst farmed rabbits, evident from footage and reinforced by scientific studies, which are enabled by the animal welfare system in place. Most of the conditions of rabbits within those farms fall within the animal welfare provisions as defined by the MCOPIHR. The application of the MCOPIHR in practice evaluates the welfare of rabbits from a starting point that the human methods of exploiting animals are morally sound and has therefore shaped legislation on economic based practice. The contemporary concept of Animal welfare in Australia appears to be based on the overriding objective of commercial productivity, which is reflected on the certain amount of care, where farm animals are fed, housed and protected from predators. Within this paradigm, animal welfare has been established into frameworks of animal husbandry as seen in the Model Code of Practice for the Welfare of

626 Aussie Farms, The Aussie Farms Repository (2014) <https://www.aussiefarms.org.au/facilities/food/rabbits $>$.

627 Marina Verga, 'Intensive rabbit breeding and welfare: development of research, trends and applications' (2000) Proceedings of the 7th World Rabbit Congress 491-506.

628 CSIRO Publishing and Primary Industry Standing Committee (Cth), Model Code of Practice for the Welfare of Animals: Intensive Husbandry of Rabbits (Primary Industries Report Series 33, 2003) 11.

629 EADY, S., A Production System for Australian Farmed Rabbits (2005) 05/038 Rural Industries Research and Development Corporation Publication, Appendix 9.

630 Ibid 14.

631 CSIRO Publishing and Primary Industry Standing Committee (Cth), Model Code of Practice for the Welfare of Animals: Intensive Husbandry of Rabbits (Primary Industries Report Series 33, 2003) 4.

632 Ibid.

633 Animal Welfare Act 2002 (WA) s. 25; Animal Welfare Act 2002 (WA) s 94(2)(d); Animal Welfare Regulation 2003 (WA) r 6.

634 Prevention of Cruelty to Animals Act 1986 (Vic) s 6(1)b.

635 Prevention of Cruelty to Animals Act 1979 (NSW) s 34A(3). 


\section{Animals: Intensive Husbandry of Rabbits.}

The recommendations from welfare science and reports such as the EFSA suggest animal welfare reforms, such as bigger cages and preference testing, ${ }^{636}$ to understand for example which choice of cages animals would tend to prefer. ${ }^{637}$ According to Bekoff and Pierce, preference testing is actually 'aversion testing ${ }^{638}$ because it examines what causes animals the most stress or pain. ${ }^{639}$ For example, scientists have studied how much stress animals experience when exposed to overcrowding, small cages and the proximity of predators. ${ }^{640}$ Therefore, as Bekoff and Pierce point out, '[w]elfare science may ask the animals what they want but the animals have actually been offered a very narrow range of questions and their answers are often ignored' ${ }^{641}$ Bekoff and Pierce argue that being driven by industry, animal welfare science formulates questions by gathering data based on answers they are looking for, therefore it is not a value-neutral science. ${ }^{642}$ According to Bekoff and Pierce, 'preference testing' research is usually to learn how serious a welfare issue is, and more importantly whether it will compromise commercial productivity or experimental results, ${ }^{643}$ which ethically does not translate to finding out what animals want or need or what is best for them. ${ }^{644}$

In light of the above there is a need to introduce an alternative framework to the current paradigm of animal welfare to determine what the needs of rabbits wellbeing are. Bekoff and Pierce claim that the study of animal behaviour is a good indicator through which humans can get to know what animals really need. ${ }^{645}$ Understanding the ethology and natural behaviour of what animals want and need, which is to be free to live their lives according to their own interests and free from exploitation, is what Bekoff and Pierce refer to as 'Animal Wellbeing'. ${ }^{646}$ Therefore, in the next section I examine what the concept of Animal Welfare as defined by the RSPCA and AHA means in light of the real needs and natural behaviours of rabbits. I explore whether the Five Freedoms can be met within the caged rabbit meat industry using rabbit ethology as a reference point to compare their needs.

\subsubsection{Analysis Two: The Oxymoron of Caged Animal Welfare}

In the previous section, the basic needs of rabbits as defined by the Model Code of Practice for the Welfare of Animals: Intensive Husbandry of Rabbits ${ }^{647}$ (MCOPIHR) were analysed against industry practices through footage obtained from different farms in Victoria and Western Australia. This demonstrated the resultant welfare of rabbits in practice reflected by the needs of economic production.

In this section, I analyse whether adequate standards of animal welfare are achievable in caged environments and ask what animal welfare means in terms of the wellbeing of rabbits within meat farms. To assess how achievable animal welfare is, as defined by the RSPCA ${ }^{648}$ and Animal Health Australia, ${ }^{649}$ within the caged rabbit meat industry, I compare the Five Freedoms to current animal welfare practices, industry recommendations, and the analysis of footage from the previous section. I ask whether each of the Five Freedoms is an achievable goal or whether the concept of animal welfare in the caged rabbit meat industry is in effect a contradiction in terms, an oxymoron.

This section therefore draws on the work of Bekoff and Pierce by using an ethological study of rabbits to assess how their needs are met within the rabbit meat industry. Although there have been several studies on the welfare of rabbits in intensive farms, ${ }^{650}$ very few have addressed rabbit ethology. In 2005, a Dutch

636 Scientific Panel on Animal Health and Welfare, 'The Impact of the current housing and husbandry systems on the health and welfare of farmed domestic rabbits' (2005) 267 The EFSA Journal, 8-29.

637 See for example work by Marian Dawkins. DAWKINS, M., Cage height preference in litter reared and cage reared hens (1985) 24 British Poultry Science 177-182.

638 BEKOFF, M.- PIERCE, J., The Animals' Agenda: Freedom, Compassion and coexistence in the Human Age (Beacon Press, 2017) 22.

639 Ibid

640 Ibid.

641 Ibid 24.

642 Ibid 27.

643 Ibid 22.

644 Ibid 40.

645 Ibid 24.

646 BEKOFF, M.- PIERCE, J., The Animals' Agenda: Freedom, Compassion and coexistence in the Human Age (Beacon Press, 2017) 174.

647 CSIRO Publishing and Primary Industry Standing Committee (Cth), Model Code of Practice for the Welfare of Animals: Intensive Husbandry of Rabbits (Primary Industries Report Series 33, 2003), 1.

648 RSPCA, Five freedoms for animals (12 Jun 2009) <http://kb.rspca.org.au/five-freedoms-for-animals_318.html>.

649 Animal Health Australia, About us (19 July 2018)<https://www.animalhealthaustralia.com.au/who-we-are/company-profile/> 650 See for example: Scientific Panel on Animal Health and Welfare, 'The Impact of the current housing and husbandry systems on the health and welfare of farmed domestic rabbits' (2005) 267 The EFSA Journal, 12; Marina Verga, 'Welfare aspects in rabbit rearing and transport' (2009) 8(1) Italian Journal of Animal Science, 191-204.

162 Derecho Animal. Forum of Animal Law Studies, vol. 10/2 
livestock sponsored study entitled The Brief of Requirements of the Rabbit (BoR) was published on the rabbit's ethological needs as a species and what that translates to regarding their environment. ${ }^{651}$ The findings relating to the ethological needs of rabbits as identified by the BoR are summarised in Appendix 3C.

The following analysis is arranged according to each of the Five Freedoms. Under each Freedom there is a description of Australian rabbit meat industry practice relating to that Freedom compared to the ethological needs of rabbits as a species.

First Freedom: Freedom from hunger and thirst: by ready access to fresh water and a diet to maintain full health and vigour. ${ }^{65}$

According to the Commonwealth Scientific and Industrial Research Organisation (CSIRO), feed costs are estimated at $72 \%$ of the total cost of production. ${ }^{653}$ Therefore rabbits are usually fed with a single complete feed mixture offering no variety, nor the possibility for choice. ${ }^{654}$ Incomplete, unbalanced feed, especially one lacking in the correct calcium to phosphorus ratio, can also contribute to overgrown teeth (Malocclusion) resulting in difficulty in eating and drinking causing anorexia and starvation. ${ }^{65}$ According to some veterinarians, $30 \%-50 \%$ mortality rate on farms is usually caused by nutritional problems. ${ }^{656}$

In intensive meat production systems, feed is always distributed in the same location. Rabbits are highly motivated in foraging and nutritional enrichment. ${ }^{657}$ In nature, they spend a large amount of time and effort searching for food. Rabbits eat many times per day and should be able to eat whenever they feel the need. ${ }^{658}$ According to the BoR, for physiological comfort rabbits need an excretion area distinct from a feeding and resting area ${ }^{659}$ and their diets should contain enough fibre for prevention of digestive problems. ${ }^{660}$

The inappropriate quality and quantity of feed to maintain full vigour and the inability to reach food or water due to density, as seen in the previous section, breach the First Freedom.

\section{Second Freedom: Freedom from discomfort: by providing an appropriate environment including shelter and a comfortable resting area ${ }^{661}$}

The artificial, confined environment and unsanitary conditions that appear to be a significant problem in accepted husbandry systems in meat farms seriously disrupt normal behaviour. ${ }^{62}$ Some of the significant environmental stressors in caged rabbits ${ }^{663}$ come from the cage raising system which restricts rabbits' instincts to protect themselves, therefore elevating their stress by feeling exposed to noises and other animals or predators without any defence. ${ }^{664}$

According to the NSW Department of Primary Industry and the MCOPIHR, rabbits in food production systems must be caged. ${ }^{665}$ In the accepted husbandry system, each rabbit is confined to a small wire cage (45 $\mathrm{cm}$ high, and an area of $0.07 \mathrm{~m}^{2}$ ), as recommended in the MCOPIHR. Rabbits attempt to divide their living space into separate areas for feeding, resting and excretion. ${ }^{666}$ Depending on the degree of relaxation, rabbits prefer to rest in a crouched position (lying alert), or with their hind legs stretched out laterally or behind the

651 Jessica M R Cornelissen et al, Report 524: Brief of Requirements of the Rabbit (2011) Wageningen UR Livestock Research. 652 RSPCA, Five freedoms for animals (12 Jun 2009) <http://kb.rspca.org.au/five-freedoms-for-animals_318.html>.

653EADY, S., Farmed Rabbits in Australia (2003) 02/144 Rural Industries Research and Development Corporation Publication 1-46. 654 Scientific Panel on Animal Health and Welfare, 'The Impact of the current housing and husbandry systems on the health and welfare of farmed domestic rabbits' (2005) 267 The EFSA Journal, 1-171.

655 Vetstream. 2017. Dental malocclusion - overgrowth. [ONLINE] Available at: https://www.vetstream.com/treat/lapis/ freeform/dental-malocclusion-overgrowth. [Accessed 8 June 2018].

656 STAIGHT, K., Breeding Rabbits, ABC Landline (online) 9 November <http://www.abc.net.au/tv/programs/landline/old-site/ content/2008/s2736433.htm>.

657 Scientific Panel on Animal Health and Welfare, 'The Impact of the current housing and husbandry systems on the health and welfare of farmed domestic rabbits' (2005) 267 The EFSA Journal, 1-171.

658 CORNELISSEN, J.M.R. et al, Report 524: Brief of Requirements of the Rabbit (2011) Wageningen UR Livestock Research, 11. 659 Ibid.

660 Ibid 14.

661 RSPCA, Five freedoms for animals (12 Jun 2009) <http://kb.rspca.org.au/five-freedoms-for-animals_318.html>.

662 See Scientific Panel on Animal Health and Welfare, 'The Impact of the current housing and husbandry systems on the health and welfare of farmed domestic rabbits' (2005) 267 The EFSA Journal 1-171; MARAI, I.M.- RASHWAN, A.A., Rabbits behavioural response to climatic and managerial conditions - a review (2004) 47 (5) Arch. Tierz. Dummerstorf 469-482.

663 VERGA, M., Intensive rabbit breeding and welfare: development of research, trends and applications (2000) Proceedings of the 7th World Rabbit Congress, 491-506.

664 SLOOTEN, L., Design for the well-being of rabbits (Master's Thesis, Delft University of Technology, 2014) 107.

665 TAYLOR, G.- KRUGER, I., Farming meat rabbits in NSW. Profitable and Sustainable Primary Industries (NSW Department of Primary Industries PRIMEFACT 104, 2004) 1-5.

666 CORNELISSEN, J.M.R. et al, Report 524: Brief of Requirements of the Rabbit (2011) Wageningen UR Livestock Research 4. 
body or lying on their side with all legs extended ${ }^{667}$ Rabbits are extremely susceptible to high temperatures and draft and have several thermoregulation strategies, such as lying stretched out to cool down. ${ }^{668}$ In a confined system, rabbits cannot lie stretched out to thermoregulate. The confined intensive system in rabbit production farms restricts the ability to move, hide and thermoregulate, all examples of breaches to the Second Freedom.

\section{Third Freedom: Freedom from pain, injury or disease: by prevention through rapid diagnosis and treatment. ${ }^{669}$}

The grid or wire flooring which is industry standard ${ }^{670}$ often results in sore ulcerated hocks (ulcerative pododermatitis). ${ }^{671}$ The ulceration can also lead to secondary bacterial infections. ${ }^{672}$ Pain associated with ulcerated hocks often causes rabbits to remain sedentary or drag their feet behind for relief. ${ }^{673}$ As the ulceration progresses further, deep bone and tendons become infected, which causes permanent damage so that standing normally becomes impossible. ${ }^{674}$ Splay-leg is a musculoskeletal condition where a rabbit lacks the ability to adduct, i.e. extend or retract one or more of their limbs away or towards their body respectively. ${ }^{675}$ This is a common condition in meat farms due to the inability to gain traction on slippery or wire floors from already weakened joints and tissues resulting from confinement. ${ }^{676}$ The lack of movement in rabbit battery cages causes bone and spinal disorders and can lead to physical abnormalities such as osteoporosis. Slippery flooring can cause hip dysplasia and other musculoskeletal changes in growing rabbits. ${ }^{677}$

Such deformations of the vertebral column have been seen in caged New Zealand White rabbits. ${ }^{678}$ Rabbits housed in small cages often develop osteoporosis of the femur, osseous hypoplasia, and reduced bone strength ${ }^{679}$ In addition, caged rabbits often endure degenerative changes of the lumbar spine and femoral head due to the lack of basic locomotor activity. ${ }^{680}$

Rabbits within confined and unhygienic cage systems will be prone to a range of viral, bacterial and parasitic diseases, such as pasteurellosis, staphylococcus, mange and most commonly coccidiosis. ${ }^{681}$ Illness is closely related to hygiene. Rabbits avoid being in contact with their faeces and/or urine. ${ }^{682}$ Rabbits are clean in nature and as such they will typically divide their living space into separate areas, such as to lay down, to toilet and to clean themselves. ${ }^{683}$ This allows rabbits comfortable quarters by controlling their environment. ${ }^{684}$ These diseases spread rapidly between rabbits in the over-crowded conditions. Contaminated floors and cages often contain parasites (flies, fleas, ticks), rats and even deceased rabbits, ${ }^{685}$ as reinforced by data in the previous section. Rabbits housed on the bottom cages are particularly susceptible to this parasite unless all faeces are removed daily. Head tilt is highly infectious in rabbit farms due to the production of spores which are released in the urine. ${ }^{686}$ These are all breaches of the Third Freedom.

667 Ibid

668 Ibid 12.

669 RSPCA, Five freedoms for animals (12 Jun 2009)<http://kb.rspca.org.au/five-freedoms-for-animals_318.html>.

670 TAYLOR, G.- KRUGER, I., Farming meat rabbits in NSW. Profitable and Sustainable Primary Industries (NSW Department of Primary Industries PRIMEFACT 104, 2004) 1-5.

671 SLOOTEN, L., Design for the well-being of rabbits (Master's Thesis, Delft University of Technology, 2014) 90.

672 OGLESBEE, B., Blackwell's Five-Minute Veterinary Consult: Small Mammal (John Wiley \& Sons, 2nd Ed 2011).

673 Ibid.

674 Ibid.

675 Disabled Rabbits, Splay Leg in Rabbits $(2017)<$ http://www.disabledrabbits.com/splay-leg.html>.

676 Freedom for Farmed Rabbits Inc., Cruelty Evidence $(2018)<$ http://www.freedomforfarmedrabbits.com.au/farms/crueltyevidence/>.

677 CORNELISSEN, J.M.R. et al, Report 524: Brief of Requirements of the Rabbit (2011) Wageningen UR Livestock Research, 20. 678 FUENTES, G.C.- NEWGREN, J., Physiology and Clinical Pathology of Laboratory New Zealand White Rabbits Housed Individually and in Groups (2008) 47(2) J Am Assoc Lab Anim Sci, 35-38.

679 DiVINCENTI Jr., L., The Social Nature of European Rabbits (Oryctolagus cuniculus). J Am Assoc Lab Anim Sci., 55/6 (2009) $729-736$.

680 BOERS, K. et al., Comfortable Quarters for Rabbits in Research Institutions. Animal Care Centre, University of British Columbia (Vancouver BC, Canada, 2009) [Online]. Available at: http://brighteyessanctuary.org/educ/comfylabrabbits.pdf [Accessed 2 June 2018]

681 VERGA, M., Intensive rabbit breeding and welfare: development of research, trends and applications (2000) Proceedings of the 7th World Rabbit Congress, 491-506.

682 CORNELISSEN, J.M.R. et al, Report 524: Brief of Requirements of the Rabbit (2011) Wageningen UR Livestock Research, 18. 683 Ibid 11.

684 Ibid.

685 Channel Seven, 'the-disturbing-reality-behind-caged-rabbits-bred-for-their-meat', Seven News, 18 September 2016, (Bryan Seymour) <https://au.news.yahoo.com/the-disturbing-reality-behind-caged-rabbits-bred-for-their-meat-32652779.html\#page1>.

686 OGLESBEE, R., Blackwell's Five-Minute Veterinary Consult: Small Mammal (John Wiley \& Sons, 2nd Ed 2011).

164 Derecho Animal. Forum of Animal Law Studies, vol. 10/2 


\section{Fourth Freedom: Freedom to express normal behaviour: by providing sufficient space, proper facilities and company of the animal's own kind. ${ }^{67}$}

The restrictions of the farm captivity system completely prevent the natural expression of rabbit basic instincts such as sniffing, digging and chewing objects found in their environment. ${ }^{68}$

Descending from the wild rabbit and very close in behavioural characteristics, ${ }^{689}$ domestic rabbits housed in cages cannot meet their basic behavioural and social needs, which have evolved over millions of years of living in complex environments. ${ }^{690}$ Innate physiological and behavioural needs of a rabbit, such as social contact and retreat, resting, nest building, hiding, exploring, foraging and gnawing natural objects, are not met in meat farms. ${ }^{691}$ Restrictions in movement and social behaviours lead to a complete lack of enrichment, resulting in frustration, stress and psychological health problems, ${ }^{692}$ as evident by corner clawing and bar gnawing. ${ }^{693}$ Manipulation of darkness and light, such as indicated by the code of practice in Victoria, ${ }^{694}$ also affect the rabbits' natural crepuscular rhythm. ${ }^{695}$

Consider for example the space provisions in the MCOPIHR, where each rabbit is confined to a small wire cage $\left(45 \mathrm{~cm}\right.$ high, and an area of $\left.0.07 \mathrm{~m}^{2}\right) .{ }^{696}$ Normal rabbit behaviour such as zigzagging and jumping, ${ }^{697}$ in which speeds of $30 \mathrm{~km} /$ hour are reached and jumps up to 1 metre in the air take place, ${ }^{698}$ cannot be achieved. All are examples of not meeting the Fourth Freedom.

Fifth Freedom: Freedom from fear and distress: by ensuring conditions and treatment which avoid mental suffering. ${ }^{699}$

The isolation of breeding does and bucks and the breaking of bonds are causes of stress in rabbits. ${ }^{700}$ Rabbits are gregarious animals and need the presence of others of their kind; they have a high motivation for social contact. ${ }^{701}$ There are dominance hierarchies within the environment which need to be observed, and aggressive behaviours are brought on by inappropriate immediate introduction of male to females for mating within a very confined or dense environment. ${ }^{702}$ Rabbits need to initiate or avoid social contact or physical contact. $^{703}$

Keeping animals in overly confined conditions causes suffering. ${ }^{704}$ It is reported by investigators that caged rabbits often look unhealthy and depressed, sitting in a hunched position for hours on end. ${ }^{705}$ The extreme boredom induces stereotypic behaviours such as inactivity, biting the cage corner bars, over-eating, playing with the water supply, excessive body grooming, frequent shaking of the head and moving around in repeated circles (always in the same way). These are all considered typical for rabbits kept in confined conditions. ${ }^{706}$

687 RSPCA, Five freedoms for animals (12 Jun 2009) $<$ http://kb.rspca.org.au/five-freedoms-for-animals 318 .html $>$.

688 CEBALLOS, M.C., et al., Environmental enrichment for rabbits reared in cages reduces abnormal behaviors and inactivity. Animal Production, 46/6 (2017)1088-1093.

689 Scientific Panel on Animal Health and Welfare, 'The Impact of the current housing and husbandry systems on the health and welfare of farmed domestic rabbits' (2005) 267 The EFSA Journal, 12.

690 DIXON, M.L., The effects of spatial restriction on the behavior of rabbits (Oryctolagus cuniculus) (2010) 5(6) Journal of Veterinary Behaviour, 302-308.

691 Ibid.

692 Scientific Panel on Animal Health and Welfare, 'The Impact of the current housing and husbandry systems on the health and welfare of farmed domestic rabbits' (2005) 267 The EFSA Journal, 1-171.

693 BEKOFF, M.- PIERCE, J., The Animals' Agenda: Freedom, Compassion and coexistence in the Human Age (Beacon Press, 2017) 37.

694 Department of Agriculture (Vic), Code of Practice for the Intensive Husbandry of Rabbits (State of Victoria).

695 FAYEZ, M. et al., Rabbits behaviour under modern commercial production conditions - a review. Arch. Tierz., Dummerstorf, 46/3 (2003) 357-376.

696 CSIRO Publishing and Primary Industry Standing Committee (Cth), Model Code of Practice for the Welfare of Animals: Intensive Husbandry of Rabbits (Primary Industries Report Series 33, 2003) 4

697 CORNELISSEN, J.M.R. et al, Report 524: Brief of Requirements of the Rabbit (2011) Wageningen UR Livestock Research, 18. 698 Ibid.

699 RSPCA, Five freedoms for animals (12 Jun 2009)<http://kb.rspca.org.au/five-freedoms-for-animals_318.html>.

700 Scientific Panel on Animal Health and Welfare, 'The Impact of the current housing and husbandry systems on the health and welfare of farmed domestic rabbits' (2005) 267 The EFSA Journal, 12.

701 CORNELISSEN, J.M.R. et al, Report 524: Brief of Requirements of the Rabbit (2011) Wageningen UR Livestock Research, 16. 702 DIVINCENTI JR, L.- REHRIG, A.N., The Social Nature of European Rabbits (Oryctolagus cuniculus)' (2016) 55(6) J Am Assoc Lab Anim Sci., 729-736.

703 CORNELISSEN, J.M.R. et al, Report 524: Brief of Requirements of the Rabbit (2011) Wageningen UR Livestock Research, 16. 704 Scientific Panel on Animal Health and Welfare, 'The Impact of the current housing and husbandry systems on the health and welfare of farmed domestic rabbits' (2005) 267 The EFSA Journal, 14.

705 Animal Liberation NSW. Rabbits $(2017)<\mathrm{https}$ ://www.animal-lib.org.au/campaigns/animals-forfood/rabbits>.

706 BOERS, K. et al, 'Comfortable Quarters for Rabbits in Research Institutions. Animal Care Centre' (2009) University of British 
The position of the Animal Welfare Science Centre (AWSC) at the University of Melbourne, ${ }^{707}$ as discussed in Chapter Two, is that a stereotypic behaviour such as bar gnawing is a coping mechanism to environmental changes which is not classified as a negative state of welfare ${ }^{708}$ However, according to Bekoff and Pierce, stereotypic behaviours which are prevalent among farm animals are a clear sign of psychological distress and a clear violation of the Fifth Freedom. ${ }^{709}$ Stereotypies are a direct outcome of captivity as they are completely absent in the wild. ${ }^{710}$ Stereotypies develop from adaptive behavioural responses to cope with continuously preventing animals from natural behaviour such as hiding, foraging and digging. ${ }^{711}$ Animal welfare scientist, Reinhardt, explains that '[m]aladaptive behaviours such as stereotypies are generally referred to as an animal's 'abnormal behaviour' which is a misleading term, as those behaviours are brought about due to the inappropriate conditions under which the animal is forced to live, which are in themselves abnormal to a species and not the animal's attempts to adapt to them'. ${ }^{712}$

In addition, transportation and pre-slaughter phases of farmed rabbits including catching, fasting as indicated by AS 4466:1997, and holding at the abattoir are considered major stressors and those have been documented by scientific studies. ${ }^{713}$ All are examples that breach the Fifth Freedom.

This section aimed to identify whether an animal welfare concept such as the Five Freedoms can achieve the wellbeing for rabbits within caged industries, or whether defining animal welfare in such circumstances is an ideal. Both the EFSA and BoR have concluded that there are no genetic differences that cause farmed rabbits to have different needs from laboratory rabbits or pet rabbits, and there will be few differences from wild rabbits ${ }^{714}$ as rabbits have been domesticated relatively recently, compared with other domestic animals. ${ }^{715}$ Domestic rabbits show behaviours typical of wild rabbits such as mating, maternal behaviour, nest building, and the social system. ${ }^{716}$ Therefore, when comparing the practices inflicted on rabbits in intensive farms to the real needs of rabbits as identified by ethological studies, rabbits in intensive farming systems lose all Freedoms as their movements and natural behaviours are revoked, causing breaches in welfare from the reference point of what rabbits need.

As Bekoff and Pierce argue, the focus of animal welfare is on minor improvements to caging systems all while allowing controlled biological development, regularised feeding, unnatural lifespan, inability to engage in normal social behaviour, deprived maternal instincts and isolation, ${ }^{717}$ all which violate the basis on which welfare sits: the Five Freedoms. ${ }^{718}$ For the reasons discussed above and shown within the previous two sections, ethological studies as proposed by Bekoff and Pierce in the understanding of animal cognition and feelings ${ }^{719}$ in this case the rabbit, should inform and lead our moral judgements to advance animal wellbeing. This will be the subject of discussion in Chapter Five.

\subsection{Conclusions}

Of all the industries of animal use, the situation of animals confined for food imposes the most severe welfare problems according to a survey of the number of animal welfare studies conducted across the spectrum of the various forms of rabbit use by humans. ${ }^{720}$ The survey shows that the largest number of scientific welfare

Columbia, Vancouver BC, Canada, (Online) <http://brighteyessanctuary.org/educ/comfylabrabbits.pdf; Maria Camila Ceballos et al, 'Environmental enrichment for rabbits reared in cages reduces abnormal behaviors and inactivity' (2017) 46(6) Animal Production, 1088-1093.

707 According to Caulfield, this group, led by Prof Hemsworth, has been the leading group in animal welfare science in Australia and has received much of its funding from primary industry (meat and livestock Australia; Dairy Australia; Australian Wool Innovation; the Australian Egg Corporation and Australian Pork limited): CAULFIELD, M., Animals in Australia (Vivid Publishing, 2018) 8889.

708 CAULFIELD, M., Animals in Australia (Vivid Publishing, 2018) 89.

709 BEKOFF, M.- PIERCE, J., The Animals' Agenda: Freedom, Compassion and coexistence in the Human Age (Beacon Press, 2017) 37.

710 Ibid 69.

711 Ibid.

712 REINHARDT, V.- REINHARDT, A., Variables, Refinement and Environmental Enrichment for Rodents and Rabbits kept in Research Institutions (Animal Welfare Institute, 2006) 7.

713 VERGA, M., Welfare aspects in rabbit rearing and transport (2009) 8(1) Italian Journal of Animal Science, 191-204.

714 Scientific Panel on Animal Health and Welfare, 'The Impact of the current housing and husbandry systems on the health and welfare of farmed domestic rabbits' (2005) 267 The EFSA Journal, 12.

715 Ibid.

716 Scientific Panel on Animal Health and Welfare, 'The Impact of the current housing and husbandry systems on the health and welfare of farmed domestic rabbits' (2005) 267 The EFSA Journal, 12.

717 BEKOFF, M.- PIERCE, J., The Animals' Agenda: Freedom, Compassion and coexistence in the Human Age (Beacon Press, 2017) 33-34.

718 Ibid 8.

719 Ibid 24.

720 ROELOFS, S., Domestic Rabbit Welfare: Welfare issues surrounding a multi-purpose animal (Master's Thesis, Utrecht 166 Derecho Animal. Forum of Animal Law Studies, vol. 10/2 
studies has been given for the welfare of rabbits raised for meat, ${ }^{721}$ which correlates directly with the severity of welfare compromises within that industry. ${ }^{722}$

Based on current observational data, published studies of the welfare of caged rabbits ${ }^{723}$ and what science is teaching us about the ethology of rabbits, welfare within the caged meat industry is not achievable. This is reinforced by the prevalent causes in the demise of several rabbit farms. ${ }^{724}$ The Rural Industries Research and Development Corporation (RIRDC) has identified that the intensive rabbit meat industry has regressed due to disease and animal welfare issues. ${ }^{725}$ It is also believed by some veterinarians that $30 \%-50 \%$ mortality rate on farms is caused by nutritional problems or pathogens. ${ }^{726}$ In addition, the RSPCA's view on rabbit farming is that it results in a number of welfare concerns ranging from confinement to preventing rabbits from satisfying their behavioural, social and physiological needs. ${ }^{727}$

There is a failure to translate what science is uncovering on rabbit behaviour into practice. Such a failure to translate is what Bekoff and Pierce refer to as the 'knowledge translation gap'. ${ }^{728}$ An example of a Knowledge Translation Gap is the failure to update the MCOPIHR with species specific ethological considerations, even though the MCOPIHR claims that " $[t]$ he Model Codes may be revised to take account of advances in the understanding of animal physiology and behavioural technology changes in animal husbandry and their relationships to the welfare of animals, ${ }^{729}$

The inability of the animal welfare concept to achieve the wellbeing of rabbits within the meat industry as shown in the previous sections lends support to Bekoff and Pierce's criticism on welfare such that '[a]s long as welfare is driven by an economic agenda, it cannot adequately protect animals' ${ }^{730}$ In line with that, I suggest that in order to protect the inherent interests of rabbits, independent of their use by humans, a step towards this goal is to organise a reform around an animal-centred 'science of well-being' that proposes a shift from welfarism to a more compassionate moral framework ${ }^{731}$ by incorporating species-specific ethological studies and organises the protection law around the rabbit as a species rather than around their use. This is the subject of discussion in the next chapter.

\section{Chapter 5. Discussion - Down the Rabbit Hole of Morality - A Need for Reform}

\subsection{Introduction}

Chapter Three examined how the domestic rabbit under specific industries is regulated, and what animal welfare protection is afforded to them. This demonstrated that inconsistencies existed in the application of animal welfare protection on domestic rabbits. Chapter Four examined the two animal welfare regimes under which the rabbit falls in the meat industry: the animal welfare regime as applied to the domestic rabbit during the rabbits' life on the farm underpinned by the Model Code of Practice for the Welfare of Animals: Intensive Husbandry of Rabbits ${ }^{732}$ (MCOPIHR); and the other during slaughter as dictated by Australian Standards of slaughter and the broad animal welfare sections contained within these standards. ${ }^{733}$

University, 2016)13.

721 Ibid.

722 BEKOFF, M.- PIERCE, J., The Animals' Agenda: Freedom, Compassion and coexistence in the Human Age (Beacon Press, 2017) 32 .

723 VERGA, M., Welfare aspects in rabbit rearing and transport (2009) 8(1) Italian Journal of Animal Science, 191-204.

724 TWOMEY, S., Farmed rabbit on the fall in Australia as producer numbers drop, The Weekly Times (online) 2014

$<$ http://www.weeklytimesnow.com.au/agribusiness/farmed-rabbit-on-the-fall-in-australia-as-producer-numbers-drop/ newsstory/0823d9540dce1951d15314622591d251>.

725 WILLIAMS, S.- PATTINSON, R., Animal Industries Five Year RD\&E Plan 2013-2018 (2014) 14/055 Rural Industries Research and Development Corporation Publication, 5-6.

726 STAIGHT, K., Breeding Rabbits, ABC Landline (online) 9 November < http://www.abc.net.au/tv/programs/landline/old-site/ content/2008/s2736433.htm>.

727 RSPCA, What is the RSPCA's view on farming rabbits for meat? (19 September 2016) <http://kb.rspca.org.au/what-is-the-rspcasview-on-farming-rabbits-for-meat_357.html>.

728 BEKOFF, M.- PIERCE, J., The Animals' Agenda: Freedom, Compassion and coexistence in the Human Age (Beacon Press, 2017) 13 .

729 CSIRO Publishing and Primary Industry Standing Committee (Cth), Model Code of Practice for the Welfare of Animals: Intensive Husbandry of Rabbits (Primary Industries Report Series 33, 2003) preface.

730 BEKOFF, M.- PIERCE, J., Animal welfare cannot adequately protect nonhuman animals: The need for a science of animal wellbeing (2016) 2016.067 Animal Sentience 2-3.

731 BEKOFF, M.- PIERCE, J., The Animals' Agenda: Freedom, Compassion and coexistence in the Human Age (Beacon Press, 2017).

732 CSIRO Publishing and Primary Industry Standing Committee (Cth), Model Code of Practice for the Welfare of Animals: Intensive Husbandry of Rabbits (Primary Industries Report Series 33, 2003).

733 Australian Standard for Hygienic Production of Rabbit Meat for Human Consumption, SCARM Report 59, AS 4466:1998; Australian Standard for Hygienic Production of Rabbit Meat for Human Consumption, SCARM Report 59, AS 4466:1997; Australian 
The conditions under which rabbits are raised for food were examined in Chapter Four by evaluating the provisions of the MCOPIHR in practice against empirical data from intensive rabbit meat farms across several jurisdictions. The Five Freedoms animal welfare concept underpinning some of the Australian national animal welfare bodies were also assessed against the rabbit meat industry practices in order to identify the needs for reform.

The aim of this chapter is to summarise the main shortfalls highlighted from the research in Chapters Three and Four which affect the wellbeing of domestic rabbits in meat farms and introduce a reform. The reform proposed in this chapter is an integrated model which is framed by using Bekoff and Pierce's theory of the 'science of animal wellbeing' ${ }^{734}$ With this in mind, the reform works on using the science of rabbit ethology to help us understand what the real behaviours and needs of rabbits are in order to inform, elevate and guide our moral attribution towards this species. This is centred on an intrinsic animal wellbeing as an ethic of human coexistence with animals, with no human entitlement for raising and killing animals for food or research, in contrast to animal welfare. Following from that, Bekoff and Pierce's theory of animal wellbeing is adopted as part of this thesis's framework with the long-term view that rabbits will not be used as food.

Within the reform, I argue for a ban on rabbit meat farms based on findings from Chapters Three and Four. The investigations highlighted in those chapters show that animal welfare cannot protect rabbits within the caged rabbit meat industry. The long-term aim of the reform is to incrementally step towards a new legal status for the rabbit which shifts their moral attribution from what it is currently, i.e. 'pest', to one in which the rabbit takes their appropriate place in society, such as 'companion' (in the case of a domesticated rabbit). It is thought that the latter will make killing domestic rabbits for human consumption illegal. Steps towards its realisation is proposed as future recommended work in the concluding chapter.

To begin with, Section 5.2 summarises the shortfalls in animal welfare applied to domestic rabbits, as analysed in this thesis, and the impact this has on rabbit wellbeing. It discusses how current standards of animal welfare fail to protect rabbits within cages and what effect the current approach to animal welfare science in Australia has on rabbits. I also identify why large-scale rabbit meat farms in Australia cannot exist without the use of confinement such as cages and introduce the need for a reform into a new animal wellbeing framework.

Section 5.3 introduces Bekoff and Pierce's 'science of animal wellbeing' as a better ethical framework for the treatment of animals than the current animal welfare framework. I explain the strengths of Bekoff and Pierce's notion of animal 'well-being' ${ }^{735}$ which aims to bridge the gap between animal welfare and ethics and is based on the ethics of human coexistence with animals, with no human entitlement for raising and killing animals for food or research in contrast to animal welfare.

Section 5.4 discusses how society's attitudes towards rabbits with their status of 'pest' influences the rabbit's legal protection. I present a summary of social and psychological research that examines the effect of the different categorisations of rabbits, such as pet, 'pest' and 'profit animals', and what it means to their welfare. The process of categorisation of animals can diminish their intrinsic value and perceived capacity to suffer, leading to reduced human moral concern towards them. ${ }^{736}$ This can subsequently drive animal welfare laws such as 'necessary' suffering on those categories of animals if a substantial benefit to humans is likely to occur, such as in the industries of food and research. ${ }^{737}$

Section 5.5 presents an integrated model of theory and advocacy in practice that supports a proposed reform to ban rabbit meat farms based on the notion that large-scale rabbit meat farms cannot exist without cages, and that cages cannot provide appropriate animal welfare to rabbits within confinement. I use Garner's theory of incremental change of animal welfare reform, ${ }^{738}$ in which he argues for using current knowledge in animal welfare to push the boundaries of what is considered 'necessary', ${ }^{739}$ as a social driver for a moral shift aimed at effecting law reform. ${ }^{740}$ To complement Garner's political theory of incremental change I deploy Spira's approach to advocacy ${ }^{741}$ as steps to implement incremental change in practice, for example choosing

Standard for the Hygienic Production of Meat and Meat Products for Human Consumption, FRSC Technical Report No. 3, AS 4696: 2007

734 BEKOFF, M.- PIERCE, J., The Animals' Agenda: Freedom, Compassion and coexistence in the Human Age (Beacon Press, 2017).

735 BEKOFF, M.- PIERCE, J., The Animals' Agenda: Freedom, Compassion and coexistence in the Human Age (Beacon Press, 2017).

736 LOUGHNAN, S. et al, The role of meat consumption in the denial of moral status and mind to meat animals' (2010) Appetite 55,156-159; Brock Bastian et al, ' Don't Mind Meat? The Denial of Mind to Animals Used for Human Consumption (2012) Pers Soc Psychol Bull 38, 247-256.

737 GARNER, R., Animals, Ethics and Public Policy (2010), The Political Quarterly, 81(1), 126

738 GARNER, R., Political Ideology and the legal status of animals (2002) Animal Law 8, 80.

739 GARNER, R., Animals, Ethics and Public Policy (2010), The Political Quarterly, 81(1), 126

740 GARNER, R., Political Ideology and the legal status of animals (2002) Animal Law 8, 80.

741 SPIRA, H., Fighting to win, in Peter Singer (ed), In Defense of Animals (Blackwell, 1985) 194-208.

168 Derecho Animal. Forum of Animal Law Studies, vol. 10/2 
a target issue such as the suffering of rabbits within battery cages on the basis of known public opinion concerns about battery cages.

\subsection{The Effect of the Current Animal Welfare Regime on Domestic Rabbits}

The current animal welfare regime pertaining to domestic rabbits in meat farms has been shown in this thesis to fall short on achieving animal welfare objectives in numerous ways, including: inconsistences; the application of minimum standards of animal welfare to farmed rabbits as shown in the provisions of the MCOPIHR; and the failure of the Five Freedoms as an animal welfare concept underpinning the RSPCA.

Three domestic rabbit industries were examined in Chapter Three: the research, meat and pet industries. Each industry was found to be regulated differently, and in each the standards of animal welfare practice also differed. This identified some issues in the protection of rabbits, mainly the inconsistent nature of animal welfare legislation and the context-informed, rather than species-specific, laws protecting the welfare of rabbits.

With regard to inconsistencies, as was demonstrated in Chapter Three, rabbits were found to be excluded under some economic uses from the animal welfare Acts that would normally apply to rabbits under a non-economic context, such as companion animals. Inconsistencies were highlighted in the definition under which domestic rabbits fall within specified industries which subsequently affected their animal welfare provisions. A rabbit was found not to be specified as a companion animal in any of the companion acts examined. For example, the Domestic Animal Act 1994 (Vic) specifically applies to dogs and cats. ${ }^{742}$ The rabbit is also not defined under the Companion Act 1998 (NSW) ${ }^{743}$ This is thought to be a reflection on the status of rabbits brought in from the first settlement in Australia as discussed in Chapter Three. They are considered as 'pests' in all jurisdictions up to this day. Consequently, legislation has evolved around the eradication and the exploitation of this species for commercial purposes. For example, it was highlighted in Chapter Three that rabbits as food animals in NSW fall under the definition 'stock animal' ${ }^{744}$ or 'an animal of a species which is usually kept in captivity by means of a cage ${ }^{745}$ 'in the Prevention of Cruelty to Animals Act 1979 (NSW). While the provision under section 9 of the Prevention of Cruelty to Animals Act 1979 (NSW) states that a person in charge of a confined animal should not fail to provide them with adequate exercise, the provision under section $9(1 \mathrm{~A})$ excludes the duty of providing adequate exercise if the animal is defined as a 'stock animal' or is usually kept in captivity by means of a cage.

Inconsistencies are also evident in euthanasia. For example, Part 9 of the MCOPIHR 'Euthanasia' recommends euthanasia be performed 'humanely' with cervical dislocation being an acceptable method, ${ }^{746}$ while this method of killing is not acceptable and is regarded as inhumane in the mandatory Code of Practice for the Housing of Laboratory Mice, Rats, Guinea Pigs and Rabbits. ${ }^{747}$

Inconsistencies in the application of animal welfare legislation can consequentially physically or psychologically harm rabbits if the harm is necessary for human use, such as the inability to meet the animal's Five Freedoms which underpins the animal welfare concept. The application of the MCOPIHR to domestic rabbits in the caged meat industry and the effect of the provisions of the Five Freedoms on animal welfare protection in practice were examined in Chapter Four.

Chapter Four investigated the effectiveness of animal welfare as a protection framework for rabbits in meat farms. The analysis was divided into two parts using empirical data in the form of video footage and photographic data from Australian intensive rabbit meat farms. The footage and photographic data were taken in several farms in Victoria and Western Australia between 2010-2016. Two of Australia's largest rabbit meat farms in the states of WA and Vic were included in the analysis, as well as two smaller scaled farms in Victoria. No footage was available from NSW. The empirical data analysed was obtained from websites available to the public. Those were the Animal Rights organisations Aussie Farms ${ }^{748}$ and Freedom for Farmed

742 See under purpose of the Domestic Animal Act 1994 (Vic) 'The purpose of this Act is to promote animal welfare, the responsible ownership of dogs and cats and the protection of the environment'

743 See for example section 5: 'companion animal means each of the following: (a) a dog, (b) a cat, (c) any other animal that is prescribed by the regulations as a companion animal'.

744 Prevention of Cruelty to Animals Act 1979 (NSW) s 4: 'Stock animal: which means an animal which belongs to the class of animals comprising cattle, horses, sheep, goats, deer, pigs, poultry and any other species of animal prescribed for the purposes of this definition'.

745 Ibid s9(1A)(b).

746 CSIRO Publishing and Primary Industry Standing Committee (Cth), Model Code of Practice for the Welfare of Animals: Intensive Husbandry of Rabbits (Primary Industries Report Series 33, 2003), 11.

747 Department of Primary Industries (Vic) Code of Practice for the Housing and Care of Laboratory Mice, Rats, Guinea Pigs and Rabbits, 2004 (State of Victoria, 2004). <https://www.deakin.edu.au/_data/assets/pdf_file/0003/536628/620-codeofpracticehousing-and-care.pdf $>$.

748 Aussie Farms, The Aussie Farms Repository <https://www.aussiefarms.org.au>. 
Rabbits. ${ }^{749}$ Video footage was also included in the analysis from a 2016 Australian Television, broadcaster footage of rabbit farms in Western Australia and the state of Tasmania.

The first part analysed the provisions of the Model Code of Practice for the Welfare of Animals: Intensive Husbandry of Rabbits (MCOPIHR) against the empirical data to examine whether the rabbit's welfare is achieved in practice. The second part examined the effectiveness of the Five Freedoms in providing wellbeing to rabbits within cages. The Five Freedoms were compared to current animal welfare practices, industry recommendations, and the empirical data. Both investigations were set to answer the main question posed for this thesis, i.e. whether the concept of Animal Welfare in the caged rabbit meat industry is in effect an oxymoron.

Based on rabbit ethology and behavioural studies used as a benchmark to evaluate what rabbit needs were, caging rabbits was shown to carry serious welfare issues causing physical and psychological suffering. Some of the major physical suffering was due to the lack of space to move, stretch out and thermoregulate. For example, rabbits raised for meat up to the age of slaughter have an area of $0.07 \mathrm{~m}^{2}$, approximately the size of an A4 sheet of paper, with a height of $45 \mathrm{~cm}$ as provided by the MCOPIHR. ${ }^{750}$ These conditions deprive rabbits of the instinctive ability to sit and stand with their ears erect, and occasionally to rear up, as evolutionary behaviours to increase the rabbits' field of vision on arousal, and also to thermoregulate by stretching out. ${ }^{751}$ Lack of hygiene and increased ammonia levels cause respiratory infections. The inappropriate floor types within farms lead to splay legs, sore hocks and injuries to paws as observed by investigators. There was generally a lack of inspection and treatment of injuries and diseases prevalent in all farms and the removal of the deceased as reported by investigators. Psychological stress was evident by the lack of spaces to hide, noise stressors leading to startled responses, and isolation of breeding rabbits and lack of enrichment. Unnatural and maladapted behaviour observed in stereotypies such as bar/wire-gnawing were prominent within the video footage.

Chapter Four highlighted numerous concerns in all the aspects of animal welfare related to the provisions of the MCOPIHR as above and the Five Freedoms. ${ }^{752}$ None of the Freedoms were found to be achieved in practice when comparing them to farm practices.

Caging animals is a breach of the Fourth Freedom, ${ }^{753}$ the Freedom to express natural behaviour, ${ }^{754}$ such as exercise. Confinement in cages, such as in intensive meat farms, is recognised as the most serious stressor for animals. ${ }^{755}$ According to animal welfare scientist Reinhardt, ' $[\mathrm{b}]$ eing confined in an unstructured primary enclosure is often associated with a high level of stress, anxiety and fear; maladaptive behaviours such as hairpulling and eating, bar/wire-gnawing and sham digging, ${ }^{756}$

From the evidence presented in Chapter Four of the Five Freedoms shown as an unachievable goal for animals kept in cages and the clear conditions of injuries and distress amongst farmed rabbits, which are enabled by the animal husbandry system in place, it is clear that the concept of 'animal welfare' in a rabbit use industry in which rabbits spend their lives in cages is effectively a contradiction in terms, an oxymoron. In light of the above it is argued that there is a need to introduce an alternative framework to the current paradigm of animal welfare to determine what the needs of rabbits' wellbeing are.

Bekoff and Pierce claim that the study of animal behaviour is a good indicator through which humans can get to know what animals really need. The animal welfare issues affecting rabbits presented in Chapter Four highlight the lack of acknowledgment of the behaviour of rabbits and their ethology within the animal welfare approach in Australia, as discussed in Chapter Two, which subsequently affects their welfare. The Animal welfare approach as indicated in Chapter Two is the 'biological functioning' approach which lacks emphasis on the measures assessing individual animal experiences or affect. ${ }^{757}$ Therefore, it fails to take into account the animal's subjective experience of wellbeing. For example, both the Animal Welfare Science

749 See https://abr.business.gov.au/ABN/View/96576042065

750 CSIRO Publishing and Primary Industry Standing Committee (Cth), Model Code of Practice for the Welfare of Animals: Intensive Husbandry of Rabbits (Primary Industries Report Series 33, 2003).

751 Scientific Panel on Animal Health and Welfare, 'The Impact of the current housing and husbandry systems on the health and welfare of farmed domestic rabbits' (2005) 267 The EFSA Journal, 13.

752 RSPCA, Five freedoms for animals (12 Jun 2009)<http://kb.rspca.org.au/five-freedoms-for-animals_318.html>.

753 BEKOFF, M.- PIERCE, J., The Animals' Agenda: Freedom, Compassion and coexistence in the Human Age (Beacon Press, 2017) 37.

754 'Freedom to express normal behaviour: by providing sufficient space, proper facilities and company of the animal's own kind' is the fourth welfare Freedom as listed by the RSPCA. RSPCA, Five freedoms for animals (12 Jun 2009 ) $<$ http://kb.rspca.org.au/fivefreedoms-for-animals $318 . \mathrm{html}>$.

755 BEKOFF, M.- PIERCE, J., The Animals' Agenda: Freedom, Compassion and coexistence in the Human Age (Beacon Press, 2017) 69.

756 REINHARDT, V.- REINHARDT, A., Variables, Refinement and Environmental Enrichment for Rodents and Rabbits kept in Research Institutions (Animal Welfare Institute, 2006) 3.

757 CAULFIELD, M., Animals in Australia (Vivid Publishing, 2018) 41.

170 Derecho Animal. Forum of Animal Law Studies, vol. 10/2 
Centre (AWSC) at the University of Melbourne ${ }^{758}$ and RSPCA Australia ${ }^{759}$ endorse that an animal's 'fitness' level as indicated by their reproduction of offspring is an indication of good welfare and a sense of wellbeing. ${ }^{760}$ Some international animal welfare studies on the effect of cage size on the reproductive performance and behaviour of does has reported that small cage sizes do not have a significant effect on fertility rates. ${ }^{761}$ Therefore, from a production and fitness level, rabbits may seem to cope with their artificial environments fairly well. However, according to animal welfare scientist and expert in rabbit welfare Verga, good reproduction rates do not mean that the rabbits' welfare is not affected. ${ }^{762}$ This is an argument contrary to the position taken in Australia which associates a rabbit's fitness and reproduction rate of offspring with their wellbeing. ${ }^{763}$

The above shortfalls in animal welfare legislation and animal welfare science applied in the rabbit meat industry which are driven by economy, as seen with the application of the MCOPIHR and inconsistencies, are not animal wellbeing per se. A report undertaken on the economics of animal welfare by McInerney, Animal Welfare Economics and Policy, ${ }^{764}$ explains that the primary economic role of a farmed animal such as the rabbit as a resource for human food production is through their value directly proportional to their productivity. ${ }^{765}$ This is in line with the animal welfare approach in Australia. McInerney states that the potential to produce an economically valuable output is centred on a husbandry system built around feed, housing, disease control and environmental management. This is in line with the provisions of the MCOPIHR. ${ }^{766}$

Therefore, according to McInerney, as an economically driven welfare, increasing intensification is the trend in husbandry and farming. That is to make the utilisation of animals more 'efficient' and capable of delivering higher levels of economic output. ${ }^{767}$ As discussed in Chapter Four, this type of husbandry, dominant in rabbit farms in Australia, focusing on disease control and productivity will not benefit the wellbeing of rabbits themselves. However, large-scale rabbit meat farms in Australia cannot exist without the use of confinement such as cages for several reasons. The two main reasons include the need to confine rabbits so that they do not escape and breed with wild rabbits, ${ }^{768}$ and the need to contain rabbits within enclosed areas to protect them from vectors carrying diseases such as Calici and Myxomatosis.

According to the NSW Department of Primary Industries ${ }^{769}$ farming rabbits must be carried out in a manner that prevents them from escaping and possibly interbreeding with wild rabbits. Rabbits must be kept within a rabbit-proof enclosure such as a secure shed and not be permitted to 'free-range'. ${ }^{770}$

RSPCA Australia does not oppose rabbit meat farming, however the RSPCA also advocates for rabbits to be housed in systems that '[p]roperly cater for their health, welfare and behavioural needs, while at the same time keeping them securely contained to prevent escape' ${ }^{771}$ There has been one case in Australia where a large-scale farm commenced a venture marketing 'free ranging' rabbits who were intensively stocked up in pens up to the age of 4 weeks. ${ }^{772}$ The rabbits were then sent to intensive caged style satellite farms to grow up to slaughter weight while the breeding does and bucks were kept in isolation in caged systems. ${ }^{773}$ Despite

758 According to Caulfield, this group has been the leading group in animal welfare science in Australia, led by Prof Hemsworth and has received much of its funding from primary industry (meat and livestock Australia; Dairy Australia; Australian Wool Innovation; the Australian Egg Corporation and Australian Pork limited). CAULFIELD, M., Animals in Australia (Vivid Publishing, 2018) 8889.

759 RSPCA, Five freedoms for animals (12 Jun 2009) <http://kb.rspca.org.au/five-freedoms-for-animals 318 .html>.

760 VERGA, M. et al, Welfare aspects in rabbit rearing and transport (2009) 8(1) Italian Journal of Animal Science 193. 761 Ibid.

762 Scientific Panel on Animal Health and Welfare, 'The Impact of the current housing and husbandry systems on the health and welfare of farmed domestic rabbits' (2005) 267 The EFSA Journal, 12.

763 CAULFIELD, M., Animals in Australia (Vivid Publishing, 2018) 89.

764 McINERNEY, J., Animal Welfare Economics and Policy' (2004) Report on a study undertaken for the Farm and Animal Health Economics Division of Defra.

765 Ibid.

766 CSIRO Publishing and Primary Industry Standing Committee (Cth), Model Code of Practice for the Welfare of Animals: Intensive Husbandry of Rabbits (Primary Industries Report Series 33, 2003), 1.

767 McINERNEY, J., Animal Welfare Economics and Policy (2004) Report on a study undertaken for the Farm and Animal Health Economics Division of Defra 27.

768 Ibid.

769 Department of Primary Industries (NSW), Rabbit farming: Planning and development control guidelines, environmental planning, section 7.1 (State of New South Wales, 1996). <https://www.dpi.nsw.gov.au/animals-and-livestock/other-animals/rabbit-farmingplanning>.

770 Ibid.

771 RSPCA, What is the RSPCA's view on farming rabbits for meat? (19 September 2016) <http://kb.rspca.org.au/what-is-the-rspcasview-on-farming-rabbits-for-meat 357.html>.

772 Kyogle Real Estate, Small Stock Abattoir <http://www.kyogle.com.au/documents/RABBITPDF.pdf $>$.

773 ATKINS, J., Australia's Largest Rabbit Farm, ABC NorthCoast NSW (online) 2 October 2008 $<$ http://www.abc.net.au/local/stories/2008/10/07/2380383.htm>. 
government and investment funding, the farm could not control rabbit health problems and has since shut down due to unmanageability. ${ }^{774}$ However, the founder of the farm admitted that he had been warned from experts in the field in the World Rabbit Congress in Italy that free ranging rabbits could not be achieved. ${ }^{775}$

This style of 'free ranging' rabbit farm is not an improvement in kind to the conditions of the current husbandry practices for intensive farms as set out by the MCOPIHR. Firstly, the adult breeding does and bucks are kept in caged isolation such as in intensive farms, therefore causing them stress, ${ }^{776}$ as they need the presence of others of their kind with their species' high motivation for social contact. ${ }^{777}$ Secondly, according to the interview by journalist Jonathan Atkins with the founder and director of the farm, the rabbits are only allowed to free-range up to the age of four weeks, ${ }^{778}$ in which they are not yet weaned from their mothers. Thirdly, the rabbits are sent to satellite farms during their growth period, which operate as intensive farms under similar caged conditions as listed in the provisions of the MCOPIHR.

The second issue is that costly management issues for rabbit farms in Australia have arisen. A number of fatal viruses released by the CSIRO to control the wild rabbit population could infect rabbits held within the rabbit meat industry. These include the Rabbit Haemorrhagic Disease Virus (RHDV), ${ }^{779}$ also known as 'Calici', and myxomatosis ${ }^{780}$. The use of a vaccine to prevent myxomatosis is prohibited by law in all States and Territories of Australia, ${ }^{781}$ while there is one available vaccine in Australia for Calici. ${ }^{782}$ According to some rabbit meat farmers, the cost of vaccinating rabbits against calicivirus is one of the biggest threats to the industry's survival. ${ }^{783}$ The vaccination is however seen as necessary. For example, in $201560 \%$ of domestic rabbits on a NSW intensive meat farm were reported to have been killed by a strain of Calici. ${ }^{784}$ To avoid these infections, the NSW department of Primary Industries recommends vaccinating rabbits against Calici while keeping them in purpose-built sheds and confinements which are insect-proofed from vectors carrying the diseases. ${ }^{785}$

The demise of the only 'free-range' rabbit farm and the conditions imposed by some governments for confinement of rabbits in farms as stated above, in addition to the ease of spread of disease, supports the notion that large-scale rabbit farms cannot exist outside the caged system. Therefore, as rabbit meat farms cannot exist outside of cages, the reform in this chapter will propose a ban on rabbit farms.

Having summarised the main shortfalls of the animal welfare regime on caged domesticated rabbits and the failure of the Five Freedoms as a concept underpinning animal welfare, I argue for a ban on rabbit meat farms based on the notion that large-scale rabbit meat farms cannot exist without cages, and that cages cannot provide appropriate animal welfare to rabbits within confinement. This reform will be discussed in Section 5.5. The proposed reform is framed by an ethic of the 'science of animal well-being' as proposed by Bekoff and Pierce, ${ }^{786}$ which reinforces the need for a more compassionate moral framework than animal welfare. ${ }^{787}$ The ethic of the science of animal wellbeing is introduced in the next section.

774 MARX, A., Investors' funds down the rabbit hole, The Courier Mail (online) 27 September 2010<https://www.couriermail.com.au/business/kyogle-rabbit-farm-up-for-sale/newsstory/828cd1b96c1f639a2f38cb7e5ad7eb93?sv=bdc7656df7ff977d1036b3d9f50b69b2>.

775 ATKINS, J., Australia's Largest Rabbit Farm, ABC NorthCoast NSW (online) 2 October 2008 $<$ http://www.abc.net.au/local/stories/2008/10/07/2380383.htm>.

776 Scientific Panel on Animal Health and Welfare, 'The Impact of the current housing and husbandry systems on the health and welfare of farmed domestic rabbits' (2005) 267 The EFSA Journal, 12.

777 CORNELISSEN, J.M.R. et al, Report 524: Brief of Requirements of the Rabbit (2011) Wageningen UR Livestock Research, 16. 778 ATKINS, J., Australia's Largest Rabbit Farm', ABC NorthCoast NSW (online) 2 October 2008 $<$ http://www.abc.net.au/local/stories/2008/10/07/2380383.htm>.

779 There are a number of RHDV strains present in Australia: RHDV 1 - Original virus released in 1995; RHDV1A - Variant of type 1 isolated in Sydney in 2014; RHDV1 - K5 Variant (release planned in March 2017); RHDV 2 - First recorded in mid-2015 in Australia, 2010 in Europe; RCV - A1 Non-pathogenic virus present in wild population. The Australian Veterinary Association, Rabbit Calicivirus in Australia $<$ https://www.ava.com.au/rabbit-calicivirus $>$.

780 HARCOURT BROWN, F., Myxomatosis <https://www.harcourt-brown.co.uk/articles/infectious-disease/myxomatosis>.

781 The prohibition of vaccination in NSW is found under Schedule 2, clause 17A of the Biosecurity Amendment (Pest Management) Regulation 2018 (NSW) under the Biosecurity Act 2015 (NSW).

782 Zoetis, RCD Cyclap Vaccine <https://www.zoetis.com.au/product-class-new/vaccines/cylap-rcd-vaccine.aspx>.

783 LOGAN, T., Saved by the poo: Rabbit manure the saviour for Western Australia's only commercial rabbit producer, ABC News Rural (online) 23 March $2017<$ http://www.abc.net.au/news/2014-04-21/rabbit-meat-disappearing-from-australian-tables/5400586>. 784 BECKER, J., Calicivirus wipes out half of rabbit farmer's stock in southern NSW, ABC News Rural 30 October 2015 $<$ http://www.abc.net.au/news/rural/2015-10-30/calicivirus-wipes-out-rabbit-farm-in-southern-nsw/6900080>.

785 Department of Primary Industries (NSW), Rabbit farming: Planning and development control guidelines, environmental planning, section 7.1 (State of New South Wales, 1996). <https://www.dpi.nsw.gov.au/animals-and-livestock/other-animals/rabbit-farmingplanning>.

786 BEKOFF, M.- PIERCE, J., The Animals' Agenda: Freedom, Compassion and coexistence in the Human Age (Beacon Press, 2017).

787 Ibid.

172 Derecho Animal. Forum of Animal Law Studies, vol. 10/2 


\subsection{The Need to Move Towards a Theory of Animal Wellbeing}

According to animal welfare scientist Webster, animal welfare is twofold. Firstly, it should involve the analysis of the problem as perceived by the animal which can be addressed by logic and scientific methods encapsulated usually by the concept of the 'Five Freedoms'. Secondly, it ought to address how humankind should act, based on matters of ethics and economics. ${ }^{788}$

In a critique of the Five Freedoms, animal welfare scientist McCulloch ${ }^{789}$ argues that '[t]he Five Freedoms are judged to be individually necessary and jointly sufficient as a framework for the analysis of animal welfare' ${ }^{790}$ Therefore, the satisfaction of the Five Freedoms should lead to good welfare from the animal's point of view. ${ }^{791}$ However, the comparison of the Five Freedoms in Chapter Four to current animal welfare practices, industry recommendations and the analysis of footage from Australian rabbit meat farms, showed that rabbits in caged systems lose freedom of movement and they are unable to express many of their natural behaviours. Although this may be lawful or acceptable practice it is also the case that it does not meet animal welfare from the reference point of what rabbits need. According to Bekoff and Pierce, and what has been shown in practice in Australian rabbit meat farms, regularised feeding, unnatural lifespan, inability to engage in normal social behaviour, deprived maternal instincts, disease and isolation ${ }^{792}$ all violate the basis on which animal welfare sits: the Five Freedoms. ${ }^{793}$ This renders any meaningful sense of animal welfare unachievable for rabbits in caged systems.

Considering the concept of Five Freedoms, McCulloch argues that if an animal has all their freedoms satisfied, the animal will be in a positive welfare state. According to McCulloch this is ' $[\mathrm{b}]$ ecause satisfaction of the various freedoms from (hunger, thirst, discomfort, pain, injury, disease, fear, distress and mental suffering) and the freedom to (express normal behaviour) allow the animal to flourish' ${ }^{794} \mathrm{McCulloch}$ argues that for an animal to flourish means that they will fulfil their species-specific nature. ${ }^{795}$ However, the Five Freedoms is an 'ideal', and it does not provide guidelines as to what extent they should be fulfilled for the animal to experience good welfare, i.e. they do not have an ethical component. ${ }^{796}$ Although Bekoff and Pierce agree that species-specific studies are necessary to understand animal behaviour and suffering, they argue that ' $[\mathrm{t}]$ he resultant animal welfare freedoms can easily ignore the real wants and needs of individual animals'. ${ }^{797}$ Therefore they argue that animal protection needs an animal wellbeing approach which moves away from refining or expanding on the Five Freedoms. They propose instead that animal protection should be based on an animal's intrinsic value and the recognition that animals need to be free from human exploitation as the basic ethic driving their protection. ${ }^{798}$

Before introducing the concept of 'animal wellbeing' as proposed by Bekoff and Pierce, it is worth noting that the concept of wellbeing and flourishing has been talked about by other ethicists, notably Nussbaum in her Capabilities Approach for Non-human Species. ${ }^{799}$ Nussbaum lists ten basic entitlements for animals based on their fundamental capacities which would allow them to flourish as subjects of their own lives and their own goals. ${ }^{800}$ However, as noted by McEwan, there are inconsistencies in Nussbaum's capabilities approach that renders her approach 'utilitarianist' even though she speaks in the language of rights. ${ }^{801}$ Nussbaum's model is utilitarian in that Nussbaum accepts large-scale killing of animals for food and

788 WEBSTER, A.J.F., The science of Animal Welfare

$<$ http://citeseerx.ist.psu.edu/viewdoc/download?doi=10.1.1.1001.4358\&rep=rep1\&type=pdf $>.137$.

789 McCULLOCH, S.P., A critique of FAWC's Five Freedoms as a framework for the analysis of animal welfare (Royal Veterinary College, London,2012) 1

790 Ibid.

791 Ibid.

792 BEKOFF, M.- PIERCE, J., The Animals' Agenda: Freedom, Compassion and coexistence in the Human Age (Beacon Press, 2017) 33-34.

793 Ibid 8.

794 McCULLOCH, S.P., A critique of FAWC's Five Freedoms as a framework for the analysis of animal welfare (Royal Veterinary College, London, 2012) 19.

795 Ibid 17.

796 Ibid 18.

797 BEKOFF, M.- PIERCE, J., The Animals' Agenda: Freedom, Compassion and coexistence in the Human Age (Beacon Press, 2017) 29.

798 Ibid 29.

799 SUNSTEIN, C.R.- NUSSBAUM, M. (eds), Animal Rights: Current Debates and New Directions (Oxford University Press, 2014) 299-319.

800 SUNSTEIN, C.R.- NUSSBAUM, M. (eds), Animal Rights: Current Debates and New Directions (Oxford University Press, 2014) 313.

801 McEWAN, A., Martha Nussbaum's Capabilities ‘Approach for Non-Human Species: A Preliminary Critique’ (2010) 4 Australian Animal Protection Law Journal 80-81. 
research. ${ }^{802}$ Yet Nussbaum's 'life' entitlement at least initially purports to go against killing animals for the purposes of food or research. ${ }^{803}$ Hence there is an internal contradiction in her capabilities approach that does not adequately challenge the status quo. ${ }^{804}$

In contrast to the notion of animal wellbeing put forward in Nussbaum's capabilities approach for nonhuman species, the ethical framework proposed in this thesis is based on the 'Science of Animal Wellbeing' as defined by Bekoff and Pierce. ${ }^{805}$ The science of animal wellbeing provides a suitable ethical framework to bridge the gap between welfare and ethics and is based on the ethics of human coexistence with animals with no human entitlement for raising and killing animals for food or research, in contrast to animal welfare and Nussbaum's capabilities approach. Bekoff and Pierce's approach has a clear advantage. It recognises the importance of observing animal behaviour to identify needs and is driven by an ethic not to exploit animals. Following from that, Bekoff and Pierce's theory of animal wellbeing is adopted as part of this thesis's framework with the long-term view that rabbits will not be used as food.

In The Animals' Agenda Marc Bekoff and Jessica Pierce introduce the concept of animal 'wellbeing' and contrast it with animal 'welfare'. ${ }^{806}$ The science of both animal wellbeing and animal welfare science are based on behaviour, and more recently cognition and emotion. ${ }^{807}$ What distinguishes the science of wellbeing is that it uses contemporary evidence of sentient animal cognition and behaviour to benefit individual animals by advocating for freedoms in a way that acknowledges an animal's choice and control, and a freedom not to be used by humans. ${ }^{808}$ The science of wellbeing acknowledges that science and ethics are intertwined and that our assessments of what individual sentient animals need should be based on scientific evidence and ethics. ${ }^{809}$ Following this, Bekoff and Pierce argue that by understanding the ethology and natural behaviour of what animals want and need, it becomes apparent that animals want to be free from exploitation and suffering. ${ }^{810}$ They argue that the greater the human understanding of sentient animal emotion and cognition, the greater the animal welfare concern will be towards them and the more difficult those concerns will become to satisfy, ${ }^{811}$ which will incrementally transform how we relate to animals as our morals catch up to what we know about them. ${ }^{812}$ Bekoff and Pierce's science of wellbeing is therefore trying to narrow the gap between science and ethics.

In relation to the extent of scientific knowledge in rabbit behaviour and ethology, the European Food and Safety Agency (EFSA) has reported that there has been minimal effort in documenting information and scientific studies on the rabbit, ${ }^{813}$ and a lack of data looking specifically at rabbit welfare aspects such as behaviour and enrichment. ${ }^{814}$ Personal correspondence with Marc Bekoff ${ }^{815}$ and Margo DeMello, ${ }^{816}$ president of the House Rabbit Society, indicates that ethological studies of rabbits are lacking in numbers.

On top of that, the categories under which rabbits fall, such as 'pest' or 'food' animals, which influence human behaviour and drive animal welfare laws such as 'necessary' suffering, need to be addressed and taken into account within a proposed roadmap for reform for rabbit wellbeing. It has been suggested by Spira that part of animal advocacy is to understand current attitudes towards an animal and understand where they could be encouraged to go tomorrow. ${ }^{817}$ Therefore, the following section summarises some of the effect of categorization of rabbits as 'food' or 'pest' animals on their perceived moral standing, which should be understood in line with Spira's advocacy strategy.

802 Ibid 90.

803 Ibid 80.

804 Ibid 67.

805 BEKOFF, M.- PIERCE, J., The Animals' Agenda: Freedom, Compassion and coexistence in the Human Age (Beacon Press, 2017) 29.

806 Ibid.

807 See for example: BROOM, D.M., Considering animals' feelings: Précis of Sentience and Animal Welfare (2016) 005 Animal Sentience, 1-11; BROOM, D.M., Cognitive ability and awareness in domestic animals and decisions about obligations to animals (2010) 126 Applied Animal Behaviour Science 1-11.

808 BEKOFF, M.- PIERCE, J., The Animals' Agenda: Freedom, Compassion and coexistence in the Human Age (Beacon Press, 2017) 174.

809 Ibid.

810 Ibid.

811 Ibid 28-29.

812 Ibid.

813 Scientific Panel on Animal Health and Welfare, 'The Impact of the current housing and husbandry systems on the health and welfare of farmed domestic rabbits' (2005) 267 The EFSA Journal, 2.

814 Ibid 39.

815 Email from Marc Bekoff to Author, 16 April 2018.

816 Email from Margo DeMello to Author, 01 June 2018.

817 SINGER, P., Ethics into Action: Henry Spira and the Animal Rights Movement (Rowaman \& Littlefield, 1998) 186.

174 Derecho Animal. Forum of Animal Law Studies, vol. 10/2 


\subsection{The Effect of Categorization as 'Food' or 'Pest' on the Perceived Moral Standing of Rabbits}

Chapter Three examined how some state governments' decisions changed legislation to accommodate for the rabbit's commercial use. For example, an amendment to the Meat Industry Act 1978 (NSW) in $1998^{818}$ defined the domestic rabbit as an 'abattoir animal', separating them from the wild rabbit defined as a '[g]ame animal that is not husbanded in the manner of a farmed animal and is killed in the field: rabbit' ${ }^{819}$ As such, within the context of 'abattoir animals', domestic rabbits were now defined as animals purposefully bred for food. ${ }^{820}$

It is also clear, based on the investigation of rabbit regulation made in Chapter Three, that inconsistencies in the treatment and welfare protection of rabbits are not related to their biology or sentience as a species, but on their economic role, such as food, research or as companion animals. The implication of sentience that comes with some definitions such as companion animals attaches intrinsic value to animals and gives them moral worth, from which would follow that it is wrong for humans to inflict unnecessary suffering on them. However, reducing rabbits to economic units legitimises humans to inflict 'necessary' suffering on animals if a substantial benefit to humans is likely to occur, such as in the industries of food and research. ${ }^{821}$

The effect of categorising sentient animals such as 'pet', 'pest' or 'profit' on perceptions of their intrinsic value and capacity to suffer has been documented by several authors. ${ }^{822}$ Some of those findings, in particular those which are applicable to rabbits, are summarised below. Where the term 'profit animal' is used, it is in line with the literature presented, and is taken to mean those rabbits used as food resources in the context of this discussion.

In Animals, Equality and Democracy, ${ }^{823}$ political scientist Siobhan O'Sullivan argues that the internal inconsistency in the way rabbits are treated is evident in her categorization of them as either 'free living' or 'captive' groups. ${ }^{824}$ The rabbit as a free living being is perceived as an undesirable animal or 'pest' species whose life is affected by environmental conservation and 'pest control' laws, ${ }^{825}$ rather than animal welfare Acts. ${ }^{826}$ However, as shown in the preceding chapters, the exclusion of rabbits from animal welfare Acts goes beyond free living rabbits. It extends to captive rabbits, such as rabbits killed for food, as discussed in Section 3.3.2.1. Therefore, unless defined as a companion animal, rabbits do not enjoy protection under Australian animal welfare statutes.

In a study by Wilkins and colleagues on the attribution of emotions to animals categorised as 'pets, pests and profit', it was found that animals are stripped of their moral standing when serving as 'profit' animals to humans, such as rabbits used for food. This also applied to rabbits viewed as a 'pest', causing what the author describes as a 'disengagement of animals from the moral inner circle'. ${ }^{827}$ According to Wilkins, this disengagement disenfranchises animal use for profit and pests from many animal welfare protections ${ }^{828}$ For example, as a companion animal, a rabbit would be protected directly by animal welfare Acts. ${ }^{829}$ However, under economic use, rabbits used for food, for example, can be excluded from the welfare Acts either directly or indirectly through mandated codes of practice or standards of slaughter, as discussed in Chapters Three and Four. ${ }^{830}$

In addition to the above, a study by Taylor and colleagues showed that social attitudes towards animals often differ as a function of species of animal, rather than by an issue concerning the animal such as an act of

818 Meat Industry Amendment Act 1998 (NSW) Schedule 1

819 Ibid S4(1)(A)

820 More recently, in NSW, the definition of domestic rabbits as abattoir animals has moved into the Food Act 2003 (NSW) and its regulation, under Clause 83 and clause 89 of the Food Regulation 2015 (NSW).

821GARNER, R., Animals, Ethics and Public Policy (2010) 81 The Political Quarterly, 126.

822 LOUGHNAN, S. et al, The role of meat consumption in the denial of moral status and mind to meat animals (2010) 55 Appetite 156-159; BASTIAN, B. et al, Don't Mind Meat? The Denial of Mind to Animals Used for Human Consumption (2012) 38 Pers Soc Psychol Bull 247.

823 O'SULLIVAN, S., Animals, Equality and Democracy (Palgrave MacMillan, 2011).

824 Ibid 29.

825 Game and Feral Animal Control Act 2002 (NSW); Local Lands Services Act 2013 (NSW); Catchment and Land Protection Act 1994 (Vic); Biosecurity and Agriculture Management Act 2007 (WA); Pest Plants and Animals Act 2005 (ACT); Territory Parks and Wildlife Conservation Act 2006 (NT); Natural Resources Management Act 2004 (SA); Land Protection (Pest and Stock Route Management) Act 2002 (Qld); Vermin Control Act 2000 (Tas).

826 O'SULLIVAN, S., Animals, Equality and Democracy (Palgrave MacMillan, 2011) 29.

827 WILKINS, A.M. et al, Factors affecting the Human Attribution of Emotions toward Animals (2015) 28:3 Anthrozoös, 367.

828 Ibid.

829 For example, the Prevention of Cruelty to Animals Act 1979 (NSW) and the Prevention of Cruelty to Animals Regulations 2012 (NSW).

830 For example, under section 24(1)(b)(ii) of the Prevention of Cruelty to Animals Act 1979 (NSW), it is not an offence for a person to undertake the act of 'destroying the animal, or preparing the animal for destruction, for the purpose of producing food for human consumption, in a manner that inflicted no unnecessary pain upon the animal'. 
cruelty. ${ }^{831}$ This is evident in Australia by the lack of attention rabbits have received in the number of media reports on cruelty in intensive farms, as opposed to caged hens within the egg industry, for example, which could be the result of an ingrained cultural view of the rabbit as a 'pest' species.

The prejudice against rabbits as a species was also highlighted in a study by Sevillano and Fiske that examined the status of animals as social beings. ${ }^{832}$ In their study, farm animals and rabbits were perceived as lacking physical or cognitive abilities, which made them an appropriate tool for humans to use and consume. ${ }^{833}$ In addition, the level of tameness and passiveness of caged farmed animals, such as rabbits, in comparison to their wild counterparts ${ }^{834}$ meant that they were disrespected due to the belief that they possessed low intelligence and low status. ${ }^{835}$ These animals invoked feelings of indifference in people. ${ }^{836}$ This again, as mentioned above, is reflected in the low attention rabbits have had in the Australian media on their current intensive farmed conditions.

Society's perception of rabbits as food animals or 'pests', compared to domestic companions, was explored in a semiotic analysis by Torosyan et al. ${ }^{837}$ In this analysis, Torosyan referenced rabbits on a 'sociozoological scale' whereby they were classified according to their economic worth and social position. ${ }^{838}$ A sociozoological scale is not based on biological differences, sentience or suffering, but on 'how well animals contribute to reinforcing the social order' which classifies them as either good or bad. ${ }^{839}$

On the sociozoological scale, at one end there are 'good' animals with a high moral status such as 'pets'. In contrast, 'bad' animals have a low moral status because their subordinate place is unclear or because they no longer remain quietly out of sight such as a 'pest' ${ }^{840}$ Torosyan's sociozoological scale revealed a growing trend in western society's perception of rabbits as domestic companions requiring ethical treatment, rescue and care. ${ }^{841}$ This was closely followed by the perception of rabbits as profit, such as food animals. ${ }^{842}$ Most of the articles focusing on rabbits as 'pests' peaked around 1995-2002 and were centralised in Australia and New Zealand. ${ }^{843}$ This was directly related to research on chemicals and viruses to eradicate the rabbit. ${ }^{844}$

Although the results from the study above involve western society, it is uncertain how far they can be applied to perceptions of the rabbits in Australia. There are very few statistics available in Australia on domestic rabbits as companions or those used for their meat. This is partly due to rabbits being included in statistics as part of 'other livestock farming', ${ }^{845}$ or defined under 'other animals' in companion acts and not required by law to be registered. ${ }^{846}$ However, the popularity of the domestic rabbit as a companion places them in fifth position after other companion animals ${ }^{847}$ a position which seems to have been stable for over a decade as indicated in a study conducted in $2007,{ }^{848}$ followed by a survey conducted by Animal Medicines Australia in $2016 .{ }^{849}$ Intensive Rabbit meat farms are on the decline due to animal welfare and disease issues according to the Rural Industries Research and Development Centre (RIRDC), ${ }^{850}$ although the demand for rabbit meat is increasing. ${ }^{851}$ All available statistics on rabbits in Australia concern those obtained from wild

831 TAYLOR, N.- SIGNAL, T.T., Pet, Pest, Profit: isolating differences in attitudes towards the treatment of animals (2009) 22 Anthrozoos, 134.

832 SEVILLANO, V.- FISKE, S.T., Animals as Social Objects: Groups, Stereotypes, and Intergroup Threats (2016) European Psychologist, 14.

833 Ibid.

834 Ibid 15.

835 Ibid.

836 Ibid.

837 TOROSYAN, G.F.- LOWE, B., Nobody Wants to Eat Them Alive: Ethical Dilemmas and Dual Media Narratives on Domestic Rabbits as Pets and Commodity (2013) 2012 (9) Proceedings of the New York State Communication Association 7.

838 Ibid 2.

839 Ibid.

840 TOROSYAN, G.F.- LOWE, B., Nobody Wants to Eat Them Alive: Ethical Dilemmas and Dual Media Narratives on Domestic Rabbits as Pets and Commodity (2013) 2012 (9) Proceedings of the New York State Communication Association 2.

841 Ibid 32.

842 Ibid.

843 Ibid 16.

844 Ibid.

845 Australian Bureau of Statistics Counts of Australian Businesses, including Entries and Exits, Jun 2007 to Jun 2009

846 The rabbit falls under the definition of 'any other animal that is prescribed by the regulations as a companion animal' under section 5 of Companion Animal Act 1998 (NSW) s5.

847 Animal Medicines Australia, Pet Ownership in Australia 2016 (2016) <http://animalmedicinesaustralia.org.au/wpcontent/uploads/2016/11/AMA_Pet-Ownership-in-Australia-2016-Report_sml.pdf $>, 10$.

848 FRANKLIN, A., Human-Nonhuman Animal Relationships in Australia: An Overview of Results from the First National Survey and Follow-up Case Studies 2000-2004' (2007) 15 Society and Animals 9.

849 Animal Medicines Australia, Pet Ownership in Australia 2016 (2016) < http://animalmedicinesaustralia.org.au/wpcontent/uploads/2016/11/AMA_Pet-Ownership-in-Australia-2016-Report_sml.pdf>

850 WILLIAMS, S.- PATTINSON, R., Animal Industries Five Year RD\&E Plan 2013-2018 (2014) 14/055 Rural Industries Research and Development Corporation Publication, 5-6.

851 EDWARDS, A., Rabbit meat disappearing from consumers' tables as farmers struggle with spiraling costs, 21 April 2014 ABC 
rabbits ${ }^{852}$ reflecting the main interest in rabbits as having been driven by their common status as a "pest" in all Australian jurisdictions. ${ }^{853}$

Labels humans attach to animals such as pet, pest, or food animals will deeply influence human behaviour and emotion depending on their interests towards the animals, inspiring their ethical stance by them. ${ }^{854}$ This in turn drives public opinion and eventually reform towards the animals' wellbeing. As DeMello explains, 'It's the way that people look at them [rabbits] that varies so wildly'. ${ }^{855}$ For example, the New Zealand White Rabbit can be used as food, research and as a companion, ${ }^{856}$ which subsequently includes them under different animal welfare provisions (see Table 7). The Australian Guidelines for the Housing of Rabbits in Scientific Institutions and the MCOPIHR compared in Table 7 are based on one breed of rabbit, the New Zealand White. Yet, taking the space requirements as an example, the animal welfare legislation favours rabbits in research, ultimately giving them enough space for three hops as compared to an area equivalent to an A4 sheet of paper for rabbits in meat farms.

According to Torosyan, the societal transition in attitudes towards the rabbit can be explained by the philosophical concept of 'constructiveness' as '[s]ocietal understanding of an object, practice, and/or phenomena is subject to change over time if the socially constructed categories are not maintained or are altered by social actors and should not be understood as being permanent' ${ }^{857}$ Therefore, opportunities can exist as part of advocacy for a change in moral attribution of rabbits, based on education on their behaviours and promotion of their suffering endured in caged environments.

It is in this way that the categorisation of rabbits in Australia needs to shift. This of course requires that public perception of rabbits changes. Such a change would be an incremental step towards banning rabbit meat farms. However, banning the cage would require that legislative amendments be grounded in morality, such as the current movement against the hen battery cages. ${ }^{858}$ There are significant challenges in achieving this outcome, in particular that at the moment rabbits are demonised and pushed to the margins of our moral attributions as 'pests'. This is also evidenced by the lack of public awareness of animal welfare issues within rabbit meat farms since their conception in 1987 until the first footage aired publicly in 2016.

Is it possible to shift Australian society's entrenched attitudes towards the rabbit? There are very few studies into the complex emotional behaviour of rabbits ${ }^{859}$ and a considerable amount of campaigning against them, according to their status as 'pests' in Australia. Although reform and public education are difficult, there are points of leverage that can be identified. For example, the increasing popularity of the rabbit as a companion could become a door into incremental reform. This is reinforced by the concern raised by the CSIRO division of rabbit management into the increased popularity of rabbits as companion animals:

'[i]ncreased popularity of pet rabbits may cause the general public to become more favourably disposed towards rabbits. This may make it more difficult to educate the community about the need for rabbit management. When a child's pet rabbit succumbs to myxomatosis, there is often a strong family reaction against the use of the disease in Australia. Greater community awareness and understanding of the impact of rabbits on natural environments and agriculture in Australia is needed to counteract these attitudes. $^{, 860}$

Following along the lines of incremental change, I will turn to discuss Robert Garner's perspective on incremental reform ${ }^{861}$ and Henry Spira's step-by-step advocacy strategies ${ }^{862}$ as providing the foundations for law reform and wellbeing for domestic rabbits.

News (online) <http://www.abc.net.au/news/2014-04-21/rabbit-meat-disappearing-from-australian-tables/5400586>.

852 Centre for Invasive Species Solutions, Rabbit Biocontrol in Australia <https://www.pestsmart.org.au/rabbit-biocontrol-inaustralia-key-facts/>.

853 Centre for Invasive Species Solution, Rabbit Legislation in Australia < https://www.pestsmart.org.au/pestsmart-factsheet-rabbitlegislation-in-australia/>.

854 HERZOG, H., The Moral Status of Mice (1988) 43(6) American Psychologist, 473.

855 DEMELLO, M.- DAVIS, S.E., Stories Rabbits Tell: A Natural and Cultural History of a Misunderstood Creature (Lantern Book, 2003) 263.

856 For breed traits see Cross Road Rabbitry, New Zealand Whites $<$ http://www.crossroadsrabbitry.com/about-new-zealand-whiterabbits/>.

857 TOROSYAN, G.F.- LOWE, B., Nobody Wants to Eat Them Alive: Ethical Dilemmas and Dual Media Narratives on Domestic Rabbits as Pets and Commodity (2013) 2012 (9) Proceedings of the New York State Communication Association 5.

858 ANDERSON, J., Protection for the Powerless: Political Economy History Lessons for the Animal Welfare Movement (2011) 4 Stanford Journal of Animal Law \& Policy 13

859 Email from Marc Bekoff to Author, 16 April 2018; Email from Margo DeMello to Author, 01 June 2018.

860 WILLIAMS, K. et al, Managing Vertebrate Pests: Rabbits, Bureau of Resource Sciences and CSIRO Division of Wildlife and Ecology. Australian Government Publishing Service Canberra (1995) 99

861 GARNER, R., Political Ideology and the legal status of animals (2002) 8 Animal Law 80.

862 SINGER, P., Ethics into Action: Henry Spira and the Animal Rights Movement (Rowaman \& Littlefield, 1998). 


\subsection{Ethics in Action - A Proposed Roadmap for Reform}

In the current animal welfare paradigm, taking either a pure welfare 'reform' approach or a rights approach can be crippling to the animal's wellbeing. The rational for this is twofold. First, as Garner points out, even though animal welfare is ethically flawed, animal rights is at present politically unrealistic as there are no legal systems based on animal rights. ${ }^{863}$ Secondly, a pure 'animal welfare' approach to reform is not a solution, as animal welfare is driven by an economic agenda and, as has been discussed throughout this work, the contemporary concept of animal welfare in Australia is derived from the need to realise commercial 'productivity' value. It gives no acknowledgement of the 'intrinsic value' of animals, an idea implied by the 'science of wellbeing'. ${ }^{864}$ Therefore, in order for a reform to push towards an end to animal exploitation, it has been argued that some of the minimal conditions on acceptable reform include the elimination of a particular form of exploitation such as the cage, rather than ameliorating cages through 'more humane' standards. ${ }^{865}$

On the notion of combining the two schools of thought, welfare and rights, I recommend a reform based on working within the current animal welfare paradigm, while simultaneously attending Bekoff and Pierce's 'science of animal wellbeing' as the end goal for human-animal co-existence. This combined approach supports the notion of animals having intrinsic value. The reform involves expanding the flexible animal welfare notion of 'unnecessary' to ban rabbit meat farms. This is based on Garner's incremental approach, which can be used to drive public opinion towards a legislative change. The way in which this reform can be achieved is through the use of the science of ethology to understand the suffering of rabbits in current conditions, which can be ultimately driven by advocacy strategies based on Spira's ten key points of advocacy in action. ${ }^{866}$

Garner suggests that to work within the current animal welfare paradigm can significantly improve animals' wellbeing. ${ }^{867} \mathrm{He}$ argues that by extending the animal welfare concept of what is 'unnecessary suffering' in a moral sense, public opinion can then make a positive impact on government policy. ${ }^{868}$ On that point, Garner explains that the animal rights strand of the animal protection movement in Britain and Europe has engaged in strategies to show that the ways in which animals are currently being treated is unnecessary to human benefits. ${ }^{869}$ Garner argues that ' $[\mathrm{w}]$ hat constitutes 'unnecessary' suffering is sufficiently vague to be open to debate. Indeed, the definition of 'unnecessary' has widened over the past thirty years or so to take into account changing public attitudes to animals that have, in part, been shaped by greater knowledge of the way animals can suffer ${ }^{870}$ This is reflected for example in the use of animals for cosmetic testing, which is widely regarded as unnecessary ${ }^{871}$ and is in the process of phasing out through multiple campaigns of public education since the early 1980s by advocates such as Henry Spira. ${ }^{872}$ Another example is the increasing awareness of animal suffering in intensive farms, such as hens in battery cages, which is being acknowledgement by many consumers as being unnecessary suffering. ${ }^{873}$

The term 'unnecessary' in the proposed reform is used under two different umbrellas. Firstly, within a social context, the need to consume rabbit meat in the first instance is 'unnecessary', which is reinforced by its existence as a niche market. Secondly, the term 'unnecessary' is used in the moral sense of 'unnecessary suffering' to inform the public of conditions which rabbits are exposed to during their lives in cages in farms and during slaughter, as underpinned by the work of this thesis. This is a case where, according to the sentience and ethology of rabbits, their caging and intensive farming should be prohibited because it causes unnecessary suffering.

Based on Garner's political theory of incremental change and challenges to unnecessary suffering, I argue for a ban on caged rabbit meat farms from evidence of unachievable animal welfare standards, based on scientific knowledge of the behaviour, emotional and ethological lives of rabbits as shown in Chapter Four. The inability of large-scale rabbit meat farms to exist in Australia without the use of cages, as discussed earlier

863 GARNER, R., The Politics of Animal Rights (2008) 3 British Politics 111.

864 BEKOFF, M.- PIERCE, J., The Animals' Agenda: Freedom, Compassion and coexistence in the Human Age (Beacon Press, 2017) 174.

865 BEST, S., Chewing on the rights vs welfare debate: do corporate reforms delay animal liberation? (2002) 22(2) The Animals' Agenda 15.

866 SPIRA, H., Fighting to win, in Peter Singer (ed), In Defense of Animals ( Blackwell, 1985)194-208.

867 GARNER, R., Political Ideology and the legal status of animals (2002) 8 Animal Law 78.

868 GARNER, R., The Politics of Animal Rights (2008) 3 British Politics 111.

869 Ibid 119

870 GARNER, R., Animals, Ethics and Public Policy (2010) The Political Quarterly 81(1), 125.

871 GARNER, R., Animals, Ethics and Public Policy (2010) The Political Quarterly 81(1), 125.

872 SINGER, P., Ethics into Action: Henry Spira and the Animal Rights Movement (Rowaman \& Littlefield, 1998) 129

873 GARNER, R., Animals, Ethics and Public Policy (2010) The Political Quarterly 81(1), 125.

178 Derecho Animal. Forum of Animal Law Studies, vol. 10/2 
in Section 5.2, ultimately supports the notion of banning rabbit meat farms altogether.

The ban of rabbit meat farms is proposed as an intermediate step to changing the status of domestic rabbits into a legal category of companion animal, which in the current animal welfare paradigm allows for better protection with no exclusions. In this regard, I agree with O'Sullivan in the need to tie animal welfare protection levels for low visibility animals such as rabbits used for food to the standards of animal welfare afforded to high visibility animals such as companion animals. ${ }^{874}$

The success of animal welfare reform such as banning the cage will depend on whether there is hope for legislation to shift on moral values rather than economic interests. ${ }^{875}$ The fact that rabbit meat is a niche market can render this possible. Battery cages have been a point of weakness on some of the industries using cages, such as egg-laying hens. ${ }^{876} \mathrm{~A}$ reform to support a ban of battery cages, which deprive rabbits of all behaviours that constitute their natural life, must start with public education in the current standards of rabbit production and current legal protections such as presented within this thesis. With this in mind, I introduce Spira's advocacy strategies to drive those incremental changes.

The advocacy work of Henry Spira in the animal rights arena indicates some successful strategies to follow in order to drive the proposed reform. ${ }^{877}$ Some of Spira's later work included advocating against the cruel treatment of caged hens and their use by industry giants McDonalds ${ }^{878}$ Spira modelled some of his approach on his experience with the civil rights movement, observing that change came about step-by-step. ${ }^{879}$ Spira's work therefore aligns closely with Garner's political arguments for incremental change.

Spira recommended that when working on behalf of animals, advocacy should be based on a ten-keypoint system which he refined from his successful campaigns to help future advocates end animal suffering. ${ }^{880}$ The following lists Spira's ten key point system for advocacy and policy/law reform adapted for the purpose of this work.

1. To understand the public's current thinking and where it could be encouraged to go tomorrow, a qualitative survey on Australian's perception of domestic rabbits in general and as companions and their knowledge of rabbit behaviour and rabbit meat farms should be undertaken. This is therefore proposed as future work.

2. A target should be selected on the basis of vulnerabilities to public opinion. Based on this point, I propose campaigns to show the similarity between companion rabbits and rabbits used for food. I also propose media coverage of animal welfare issues in farms and slaughterhouses as documented in this thesis. A successful example of campaigning for ethical change through heightened public awareness of immoral conditions is the US campaign against Whole Foods market in 2014 in their attempt to introduce domestic rabbit meat raised in intensive farms at a number of Californian stores. The People for the Ethical Treatment of Animals (PETA) and the House Rabbit Society led a campaign against Whole Foods over meat obtained from animals commonly kept as pets. ${ }^{881}$ This was a successful example of an educated consumer action which took the form of product boycotts and a consumer demand of products produced in the preferred manner. ${ }^{882}$

3. Set goals that are achievable. Bring about meaningful change one step at a time. Based on the notion of what is morally 'unnecessary suffering', I propose setting targets such as media talks and engaging with restaurants who serve rabbit meat.

4. Establish credible sources of information and documentation. Never assume anything. Based on that recommendation, the findings in this thesis were based on primary sources of legal analysis and international scientific studies of rabbit behaviour and can be used as backup knowledge of unnecessary suffering resulting from caging rabbits in meat farms.

874 O'SULLIVAN, S., Animals, Equality and Democracy (Palgrave MacMillan, 2011) 166-167.

875 ANDERSON, J., Protection for the Powerless: Political Economy History Lessons for the Animal Welfare Movement (2011) 4 Stanford Journal of Animal Law \& Policy 13.

876 Current petitions are underway as submission to the government as well as state/territory Premiers and Agricultural Ministers on behalf of the RSPCA towards a ban of battery cages for egg laying hens. RSPCA, End the Battery Cage

$<$ https://www.rspca.org.au/campaigns/end-the-battery-cage-public-consultation>.

877 Examples of Henry Spira's successful campaigns include pressurising the cosmetics industry to phase out its use of the Draize test and the end of face branding of cattle. SINGER, P., Ethics into Action: Henry Spira and the Animal Rights Movement (Rowaman \& Littlefield, 1998).

878 SINGER, P., Ethics into Action: Henry Spira and the Animal Rights Movement (Rowaman \& Littlefield, 1998) 166-176.

879 Ibid 17-22.

880 SPIRA, H., Fighting to win, in Peter Singer (ed), In Defense of Animals (Blackwell, 1985) 194-208.

881 RYAN, C., Whole Foods Market halts sale of rabbit, GlobalMeat News (online) 20 September 2015 $<$ https://www.globalmeatnews.com/Article/2015/09/21/Whole-Foods-Market-halts-sale-of-rabbit $>$.

882 ARROYO, A., Protestors Attack Whole Foods For Selling Rabbit Meat, Eater Denver (online) 3 April 2015 $<$ https://denver.eater.com/2015/4/3/8337615/protest-rabbit-meat-whole-foods-boulder>. 
5. Don't divide the world into saints and sinners. According to Spira, this unjudgmental way of thinking is more than a tactic and has proven to be successful in reprogramming the way people think towards animal use. ${ }^{883}$ For this point I am assuming the general public and restaurants consuming and serving rabbit meat have no perceived knowledge of current suffering rabbits endure within meat farms. Therefore, education into unknown practices can be considered as an initial step in changing their attitudes to seeing this as an 'unnecessary' practice.

6. Seek dialogue and attempt to work together to solve problems. Working with restaurants to offer alternatives such as plant-based meals based on emerging statistics in credible newspapers and journals on plant-based food popularity.

7. Be ready for confrontation if your target is unresponsive. If accepted channels don't work, prepare an escalating public awareness campaign to place your adversary on the defensive. In case of facing adversity, campaigns involving social media, interviews and billboards can be undertaken.

8. Avoid bureaucracy, by keeping within necessary collaborative groups.

9. Don't assume that only legislation or legal action can solve the problem. Familiarising and educating the public about rabbits and their emotional needs will progressively shift their status, or get a public backup to shift this status, into a status requiring more protection, such as companion animal status. Research in psychology discussed in the previous sections highlights and supports that familiarity with an animal will cause more emotional attribution towards that species. The following are key issues which should be highlighted in education campaigns:

- Public knowledge into the cruel practices in commercial rabbit industry;

- Understanding of rabbit ethology and behaviour; and

- Using studies to promote the intelligence of rabbits as a species, such as the studies of rabbits' declarative memory and consciousness discussed in Wise's epic work on legal rights for animals. ${ }^{884}$

- Ask yourself: "Will it work?" There has been considerable campaigning for the phasing out of battery cages in different animal use industries, which has successfully brought public awareness and legislation change that could be used as a roadmap to set out similar campaigns for the rabbit.

\subsection{Conclusions}

This chapter highlighted the shortfalls of animal welfare legislation and the concept of Five Freedoms as applied in practice in the caged rabbit meat industry. In light of the findings in Chapters Three and Four of unachievable animal welfare standards within the caged rabbit meat industry, it was found that animal welfare in the caged rabbit industry is in effect an oxymoron, therefore answering the thesis' main question.

Based on the inability to protect rabbits in a system of animal welfare driven by economy, an integrated model of reform has been proposed which supports a reform to ban rabbit meat farms based on the notion that large-scale rabbit meat farms cannot exist without cages, and that cages cannot provide appropriate animal welfare to rabbits within confinement. The reform model proposed combines a theoretical incremental approach by Garner, which is informed by the science of rabbit ethology and the ethic of animal wellbeing by Bekoff and Pierce, while being modelled in advocacy on Spira's step-by-step campaigning strategies. Within this reform, I use Garner's theory of incremental change of animal welfare reform, ${ }^{885}$ in which he argues for using current knowledge in animal welfare to push the boundaries of what is considered morally 'unnecessary ${ }^{886}$ as a social driver for a moral shift aimed at effecting law reform. ${ }^{887}$ To complement Garner's political theory of incremental change I deploy Spira's approach to advocacy as steps to implement incremental change in practice, such as changing the attitudes of people towards rabbits to inform policy to ban rabbit meat farms.

\section{Chapter 6. Conclusions, Recommendations and Future Research Directions}

\section{Conclusions}

This thesis examined how domesticated rabbits are regulated and protected under animal welfare Acts

883 SINGER, P., Ethics into Action: Henry Spira and the Animal Rights Movement (Rowaman \& Littlefield, 1998$) 188$.

884 WISE, S.M, Rattling the Cage: Towards Legal Rights for Animals (Perseus Books, 2000) 141-143.

885 GARNER, R., Political Ideology and the legal status of animals (2002) Animal Law 8, 80.

886 GARNER, R., Animals, Ethics and Public Policy (2010), The Political Quarterly, 81(1) 126.

887 GARNER, R., Political Ideology and the legal status of animals (2002) Animal Law 8, 80.

180 Derecho Animal. Forum of Animal Law Studies, vol. 10/2 
in Australia with a focus on the welfare of rabbits in meat farms. The research aimed to analyse if it is possible to provide adequate standards of animal welfare when rabbits are caged. This was in line with the main question posed by this research, which was whether the concept of animal welfare in the caged rabbit meat industry is in effect an oxymoron.

The response to the thesis question was developed using integrated disciplines influenced by the work of scholars working in related fields. Firstly, Marc Bekoff and Jessica Pierce, who highlight the need to understand the ethology of species as a first step of advocacy for animals towards a theory of animal wellbeing. ${ }^{888}$ Their approach puts the needs of the animals at the centre of our moral judgement and behaviour. ${ }^{889}$ On that premise, ethological and behavioural studies of rabbits were used as a benchmark to critique the current animal welfare applied in Australian rabbit meat farms. Secondly, I drew on Robert Garner's perspective on incremental change of animal welfare reform. ${ }^{890}$ Garner argues for using current knowledge in animal welfare to push the boundaries of what is considered morally 'unnecessary' ${ }^{891}$ as a social driver for a moral shift aimed at effecting law reform. ${ }^{892}$ The analysis of the conditions or common practices within rabbit meat farms in Australia is in line with Garner's recommended approach of using current animal welfare knowledge to drive incremental change. It presents new work on the rabbit meat industry and other forms of rabbit use to inform a missing gap in current animal welfare knowledge which can provide valuable resources for animal advocates. The third scholar drawn upon to develop the argument in this thesis was Henry Spira and his ten key points of advocacy. ${ }^{893}$ The advocacy strategies of Spira were put forward as practical guidelines for advocacy aimed at banning rabbit meat farms. It is within this broader advocacy framework that this thesis explored the current animal welfare regime and what it meant for the wellbeing of domestic rabbits, and subsequently proposed law and policy reforms and an agenda for future research.

The research was developed in three stages. To set the scene for understanding why the rabbit has not had much attention and to shed light on contemporary attitudes towards rabbits, Chapter Three presented an overview of relevant legislation, from the introduction of the rabbit in Australia in 1788 to the commodification of the domestic rabbit as meat within intensive farms in 1987. The main aim of providing a background to the history of the rabbit was to understand where people's thinking is at present with rabbits, and where it can go tomorrow, fundamental in implementing change in the moral attribution of the rabbit in accordance with Garner's incremental change and Spira's ten Key Points of advocacy.

A background to the status of the rabbit and their use was provided since the rabbit's introduction into Australia for sport and hunting and as a source of meat in 1788. It was documented that when the population went out of control, causing significant economic losses to the agricultural sector in the 1870s, the species was proclaimed a 'pest'. The rabbit's status as a 'pest' remains to this day, which places them at the edge of our circle of moral concern and therefore means that they do not attract the sympathy of mainstream Australian society, as seen with the lack of advocacy for rabbits within caged environments such as caged rabbits used for meat.

The regulation of the domestic rabbit industry and animal welfare regime as applied to domestic rabbits under different human uses was examined in Chapter Three, with an aim to identify the effectiveness of the standards of animal welfare on caged rabbits and what inconsistencies could arise from them. The analysis was confined to those industries in which rabbits are most commonly used and caged to explore animal welfare in situations which carry with it serious welfare concerns, such as physical and psychological suffering ${ }^{894}$ and inability to express natural behaviour. ${ }^{895}$ I examined rabbits raised and used in three industries: the caged rabbit meat industry, research, and rabbits as pets/companion animals. These industries were chosen as rabbits used within them live most of their lives in cages and those used in the research and meat industries are mainly one breed of rabbit, the New Zealand White. ${ }^{896}$ This made the animal welfare provisions, such as space and height of cages afforded to rabbits, easier for comparison in order to identify any inconsistencies within the animal welfare standards of practice. The examination was confined to three States: Victoria (Vic), New South

888 BEKOFF, M.- PIERCE, J., The Animals' Agenda: Freedom, Compassion and coexistence in the Human Age (Beacon Press, 2017) 29.

889 Ibid.

890 GARNER, R., Political Ideology and the legal status of animals (2002) Animal Law 8, 80.

891 GARNER, R., Animals, Ethics and Public Policy (2010), The Political Quarterly, 81(1),126.

892 GARNER, R., Political Ideology and the legal status of animals (2002) Animal Law 8, 80.

893 SPIRA, H., Fighting to win, in Peter Singer (ed), In Defense of Animals (Blackwell, 1985) 194-208.

894 BEKOFF, M.- PIERCE, J., The Animals' Agenda: Freedom, Compassion and coexistence in the Human Age (Beacon Press, 2017) 37.

895 'Freedom to express normal behaviour: by providing sufficient space, proper facilities and company of the animal's own kind' is the fourth welfare Freedom as listed by the RSPCA. RSPCA, Five freedoms for animals (12 Jun 2009) <http://kb.rspca.org.au/fivefreedoms-for-animals_318.html>.

896 For breed traits see Cross Roads Rabbitry, New Zealand Whites $<$ http://www.crossroadsrabbitry.com/about-new-zealand-whiterabbits/>. 
Wales (NSW), and Western Australia (WA), primarily due to the availability of empirical data from farms within WA and Vic on which an analysis could be based and the fact that the largest rabbit meat farms still in operation operate in those states.

Inconsistencies with the treatment of domestic rabbits within Animal welfare Acts were found evidenced from the exclusions of rabbits either directly or indirectly from some operations of the Acts by reference to Model Codes of Practice (MCOP). The adoption of different terms for a rabbit such as an 'Abattoir animal: Rabbit', a 'stock animal' or a 'Specified animal: rabbit' for research purposes highlighted that their welfare protection depended on their human use. Where human interests necessitate some cruelty in the treatment of rabbits, such as intensively farming rabbits for meat, the provisions were legally sanctioned by excluding rabbits from the animal welfare Acts and introducing the MCOPIHR as an animal welfare instrument within the framework of rabbit welfare within that industry.

Chapter Three identified two regimes under which rabbits fall within the meat industry: one during their life on the farm, and the other during slaughter. The two regimes and the conditions under which rabbits are raised and killed for food, through the application of the Model Code of Practice for Animal Welfare: Intensive Husbandry of Rabbits (MCOPIHR) and slaughter standards, were expanded on and scrutinised in Chapter Four.

To evaluate Australia's animal welfare regulatory approach as applied to domestic rabbits used for food, the MCOPIHR was compared in Chapter Four against the Five Freedoms. The MCOPIHR was used as the accepted standard of practice in animal welfare in the intensive husbandry of domestic rabbits for commercial production, which sets the minimum guidelines of care and management of farmed rabbits. The Five Freedoms underpin the Australian Royal Society for the Prevention of Cruelty to Animals' definition of animal welfare and therefore provided a suitable benchmark for comparison of applied animal welfare as seen with the provisions of the MCOPIHR. Although the MCOPIHR claims that 'the basic requirement for the welfare of rabbits is a husbandry system appropriate to their physiological and behavioural needs, ${ }^{897}$ it was found that it had no provision for ensuring behavioural conditions that avoid mental suffering as compared to the provision of the Fifth Freedom.

Having compared these two standards, empirical data in the form of video footage and photographic data from WA and Vic of conditions in which a significant number of rabbits are kept in Australian rabbit meat farms was used in Chapter Four to compare the provisions of the MCOPIHR and the Five Freedoms. This was done to evaluate the effectiveness of Australia's animal welfare regulatory approach as applied to domestic rabbits used for food. The animal welfare issues raised by the analysis of current husbandry practices and the MCOPIHR were then compared against international scientific studies of rabbit behaviour in line with Bekoff and Pierce's ethologically-based wellbeing approach. This provided an international benchmark for whether, biologically and behaviourally, rabbit wellbeing was being met in practice.

The results of comparing the MCOPIHR to empirical data in Chapter Four demonstrated that caging rabbits carries serious welfare issues causing mainly physical and psychological suffering. Some of the major physical suffering was due to the lack of space to move, stretch out and thermoregulate, depriving rabbits of instinctive evolutionary behaviours. ${ }^{898}$ The inappropriate wire cages were a common feature within farms leading to splay legs, sore hocks and injuries to paws as observed by investigators. There was commonly a lack of inspection and treatment of injuries and diseases in all farms in both jurisdictions investigated. Psychological stress was evident by maladaptive behaviours such as hair-pulling and stereotypies such as bar/wire-gnawing. Some injuries were evident and thought to be associated with aggressive behaviour between rabbits from forced introductions for mating purposes and overcrowded cages.

The analysis of footage from Australian rabbit meat farms showed that none of the provisions of the Five Freedoms were achieved in practice when comparing them to farm practices. For example, the isolation of breeding does and bucks and the inability to move within restricted cage size are breaches of the Fourth Freedom. ${ }^{899}$ Caging animals is a breach of the Fifth Freedom, ${ }^{900}$ the freedom to express natural behaviour such as exercise. ${ }^{901}$

897 CSIRO Publishing and Primary Industry Standing Committee (Cth), Model Code of Practice for the Welfare of Animals: Intensive Husbandry of Rabbits (Primary Industries Report Series 33, 2003), Introduction.

898 Scientific Panel on Animal Health and Welfare, 'The Impact of the current housing and husbandry systems on the health and welfare of farmed domestic rabbits' (2005) 267 The EFSA Journal, 13.

899 The Fourth Freedom is the Freedom to express normal behaviour: by providing sufficient space, proper facilities and company of the animal's own kind.

900 BEKOFF, M.- PIERCE, J., The Animals' Agenda: Freedom, Compassion and coexistence in the Human Age (Beacon Press, 2017) 37.

901 'Freedom to express normal behaviour: by providing sufficient space, proper facilities and company of the animal's own kind' is the fourth welfare Freedom as listed by the RSPCA. RSPCA, Five freedoms for animals (12 Jun 2009) <http://kb.rspca.org.au/fivefreedoms-for-animals_318.html>. 
Therefore, based on the analyses from Chapter Four from empirical data of current practice in rabbit meat farms, published studies of the welfare of caged rabbits ${ }^{902}$ and what science is teaching us about the ethology of rabbits, animal welfare within the caged rabbit meat industry was found not to be achievable and consequently considered to be an oxymoron.

Considering the findings in this thesis, areas of reform were recommended in Chapter Five. An integrated model of theory and advocacy was proposed for reform to ban rabbit meat farms. The proposed reform is framed by Bekoff and Pierce's theory of the 'science of animal wellbeing'. ${ }^{903}$ With this in mind, the reform works on using the science of rabbit ethology to help us understand what the real behaviours and needs of rabbits are to inform, elevate and guide our moral attribution towards them. This is centred on an intrinsic animal wellbeing as an ethic of human coexistence with animals, with no human entitlement for raising and killing animals for food or research, in contrast to animal welfare. Following from that, Bekoff and Pierce's theory of animal wellbeing is adopted as part of this thesis's framework with the long-term view that rabbits will not be used as food.

The integrated model for reform also draws on Garner's theory of incremental change as a goal to relieve the current suffering of rabbits. According to Garner, the concept of 'necessary suffering',904 underpinning animal welfare legislation which allows for the existence of intensive rabbit meat farms, for example, constitutes sufficient grounds to argue for an animal welfare reform. On this basis, part of the proposed reform as set out in Chapter Five expands on the flexible animal welfare notion of 'unnecessary' suffering ${ }^{905}$ to drive public opinion and ban rabbit meat farms. As complementary to Garner's political theory of incremental change I use Spira's advocacy work as a guide of incremental steps to implement change in practice. ${ }^{906}$ This combined approach informs my recommendations for law and policy reform and future research which I discuss below.

\section{Recommendations and Future Research Directions}

In this thesis, I have argued that the current inadequate animal welfare system for caged domestic rabbits used in the meat industry should be a motivation for reform leading to a ban on rabbit meat farms. The research and proposed reform have raised directions that could be explored in future research. A few areas of inquiry that deserve attention as priorities are discussed briefly below. I discuss how research can support the social and cultural change required to make a positive shift in the moral regard given to the rabbit and how this can extend into legal protection. I also highlight some ideas which could be pursued and campaigned for through legislative changes.

The idea of promoting the moral standing and emotional attribution of the rabbit through community education in their current animal welfare conditions and behavioural needs is an essential first step for their advocacy, which in the long term will bring effect to legislative reform. Based on that, I recommend the following as future research:

A qualitative community survey on the perception of domestic rabbits in general, their uses under humans and as companions. This would include gathering data on community understanding regarding rabbit behaviour and ethological needs to assess the current human understanding of rabbits. Part of the assessment would be to gather opinions on public perception on the ethics behind rabbit meat farms and the animal welfare currently protecting rabbits. This would provide a baseline for public awareness campaigns. To understand the public's current thinking and where it could be encouraged to go tomorrow is part of Spira's ten-key-point system for advocacy and policy/law reform.

Industry independent ethological research of rabbit behaviour should be proposed and encouraged to grow. The current ethological studies referenced within this thesis are based on 'livestock' and 'animal welfare' studies of caged rabbits in food and research environments, and do not attend to the full scale of studies which could be provided by, for example, rabbit sanctuaries and rabbit rescue organisations.

As far as research ideas into legislative changes, I propose the following areas of research:

Regarding the ban of rabbit meat farms, I recommend research into the similarities between battery hens and battery rabbits, and what caged rabbit welfare as depicted in this thesis means to consumers as a first step. This can lead to advocacy for the ban of rabbits in cages, which ultimately would mean a ban on rabbit meat farms since, as discussed in Chapter Five, free range rabbit farms cannot exist in Australia. The outrage

902 VERGA, M., Welfare aspects in rabbit rearing and transport (2009) 8(1) Italian Journal of Animal Science, 191-204.

903 BEKOFF, M.- PIERCE, J., The Animals' Agenda: Freedom, Compassion and coexistence in the Human Age (Beacon Press, 2017) 29.

904 GARNER, R., Animals, Ethics and Public Policy (2010) The Political Quarterly 81(1), 125.

905 Ibid.

906 SPIRA, H., Fighting to win, in Peter Singer (ed), In Defense of Animals (Blackwell, 1985) 194-208 
by the Australian public regarding caged egg hens depicted by the findings of a study by the RSPCA has shown that $65 \%$ of Australians have a concern over battery cages which has impacted their decision on whether to buy or consume eggs. ${ }^{907}$ The same logic could probably apply to rabbits, although many people eat eggs and not many people eat rabbits, therefore the public concern could be dwarfed by the fact that they do not participate in caged rabbit suffering. Research should also take into account the species-specific issues between hens and rabbits. For example, chickens are not 'pests' and do not have the kind of history that rabbits in Australia have.

The legal possibility for domestic rabbits to be awarded higher animal welfare protection should be investigated. It was shown in Chapter Three that a rabbit is not specified as a companion animal in any of the companion acts examined, which does not allow the rabbit to assume a public role in society as a companion animal such as the roles and protections given to a dog or a cat. To reconcile principles of ethics where the suffering of animals is concerned, domestic rabbits should be awarded the protection afforded to companion animals within the current animal welfare paradigm. This could make killing for food and other economic uses illegal. Some incremental approaches that could achieve a change in their protection levels are as follows:

Research into the amendment of the different companion Acts to include the rabbit in the definition of 'companion animal'. For example, the Domestic Animal Act 1994 (Vic) specifically applies to dogs and cats. ${ }^{908}$ The rabbit is also not defined under the Companion Act 1998 (NSW). ${ }^{909}$ This lack of consistency defining which animals are companions raises ethical questions about which animals are okay to eat and which are not.

The addition of rabbits to the Domestic Animals Amendment (Puppy Farms and Pet Shops) Act 2017 (Vic) as driven by Oscar's Law. ${ }^{910}$ This would forbid their sale in pet shops and monitor their breeding conditions within farms, disallowing the sale of rabbits from breeding mills, which would effectively shut down rabbit farms in which rabbits live their lives in cages. This will require a change to the current Inquiry into the Domestic Animals Amendment (Puppy Farms and Pet Shops) Bill 2016, ${ }^{911}$ which passed in June 2018 within Victoria. Experience from the US shows that this is possible and a trend in adding rabbits as companions to Acts is currently underway in the US. An amendment to the Californian legislative Act, the Pet Rescue and Adoption Act, ${ }^{912}$ is an example of what could be achieved. Starting 1 January 2019, the Californian Pet Rescue and Adoption Act will introduce the rabbit to the Act, disallowing the sale of dogs, cats, and rabbits from breeding mills. This means that stores will only be able to sell those animals on condition that they are obtained from a public animal control agency, shelter, or rescue group.

\section{Bibliography}

\section{Articles, Books, and Reports}

- ANDERSON, J., Protection for the Powerless: Political Economy History Lessons for the Animal Welfare Movement (2011) 4 Stanford Journal of Animal Law \& Policy 13

- BASTIAN, B. et al, Don't Mind Meat? The Denial of Mind to Animals Used for Human Consumption (2012) 38 Pers Soc Psychol Bull, 247.

- BEDER, S.- GOSDEN, R., Pindone Rabbit-Baiting: Cruel and Careless? (2011) UoW Discussion Paper (online) $<$ https://www.uow.edu.au/ sharonb/PindoneDiscussion.pdf $>$.

- BEKOFF, M.- PIERCE, J., The Animals' Agenda: Freedom, Compassion and coexistence in the Human Age (Beacon Press, 2017).

- BEKOFF, M.- PIERCE, J., Animal welfare cannot adequately protect nonhuman animals: The need for a science of animal well-being' (2016) 2016.067 Animal Sentience 2.

907 RSPCA, Breakthrough research finds $84 \%$ of Australians want to end the battery cage (26th November 2017) < https://www.rspca.org.au/media-centre/news/2017/breakthrough-research-finds-84-australians-want-end-battery-cage>.

908 See under purpose of the Domestic Animal Act 1994 (Vic) 'The purpose of this Act is to promote animal welfare, the responsible ownership of dogs and cats and the protection of the environment'

909 See for example section 5: 'companion animal means each of the following: (a) a dog, (b) a cat, (c) any other animal that is prescribed by the regulations as a companion animal'.

910 Oscar's law was the campaign that drove the Domestic Animals Amendment (Puppy Farms and Pet Shops) Act 2017 (Vic). The Puppy Farm and Pet Shop Bill passed the upper house vote in Victoria meaning that the number of dogs that breeders are allowed to keep will be limited and anyone selling a pet must also provide a registered source number to show where the animal was bred. It also means pet shops will no longer be allowed to sell puppies.

911 Legislative Council (Vic), Economy and Infrastructure Committee, Parliament of Victoria, Inquiry into the Domestic Animals Amendment (Puppy Farms and Pet Shops) Bill 2016 (December 2016).

912 California Legislative Council Digest, Assembly Bill No. 485 Chapter 740, AB-485 Pet store operators: dogs, cats, and rabbits (October 2017) <https://leginfo.legislature.ca.gov/faces/billTextClient.xhtml?bill_id=201720180AB485>. 
- BEKOFF, M.- ALlEN, C., Cognitive Ethology: Slayers, Skeptics and Proponents in MITCHELL, R.W. et al (eds) Anthropomorphism, Anecdotes and Animals: The Emperor' New Clothes? (Eds) New York, State University Press. (1997) 314.

- BEKOFF, M., Why "good welfare" isn't "good enough": minding animals and increasing our compassionate footprint(2008) 10 Annual Review of Biomedical Sciences T1.

- BEKOFF, M.- ALLEN, C., Animal minds, cognitive ethology, and ethics (2007) 11(3) The Journal of Ethics 299.

- BEKOFF, M., Animal Passions and Beastly Virtues: Cognitive Ethology as the Unifying Science for Understanding the Subjective, Emotional, Empathic, and Moral Lives of Animals (2006) 13(1) Human Ecology Review 39.

- BEKOFF, M., Cognitive Ethology and the treatment of non-human animals: how matters of mind inform matters of welfare (1994) 3 Animal Welfare 75.

- BEKOFF, M.- GRUEN, L., Animal welfare and individual characteristics: A conversation against speciesism (1993) 3(2) Ethics \& behaviour 163.

- BEKOFF, M., Increasing Our Compassion Footprint: The Animals' Manifesto (2008) 43(4) Zygon 771.

- BEKOFF, M., The animal's point of view, animal welfare and some other related matters (1991) 14(4) Behavioural and Brain Sciences 753.

- BEST, S., The Politics of Total Liberation: Revolution for the 21st Century (Palgrave McMillan, 2014).

- BEST, S., Chewing on the rights vs welfare debate: do corporate reforms delay animal liberation? (2002) 22(2) The Animals' Agenda 14

- BLOOM, G., Regulating Animal Welfare to Promote and Protect Improved Animal Welfare Outcomes Under the Australian Animal Welfare Strategy (Paper presented at the AAWS International Animal Welfare Conference, 1 September 2008).

- BOERS, K. et al, Comfortable Quarters for Rabbits in Research Institutions. Animal Care Centre (2009) University of British Columbia, Vancouver BC, Canada, (Online) $<$ http://brighteyessanctuary.org/educ/comfylabrabbits.pdf.

- BROOM, D., Animal welfare defined in terms of attempts to cope with the environment (1996) 27 Acta Agriculturae Scandinavica Section A, Animal Science: Supplement 22.

- BROOM, D., Indicators of Poor Welfare (1986) 142 British Veterinary Journal 524.

- BROOM, D., A History of Animal Welfare Science (2011) 59 Acta Biotheoretica 121.

- BROOM, D. M., Cognitive ability and awareness in domestic animals and decisions (2010) 126 Applied Animal Behaviour Scienc 1.

- BROOM, D. M., Animal welfare: concepts and measurement (1991) J. Auh Sci 4167.

- BROOM, D. M., Considering animals' feelings (2016) 005 Animal Sentience.

- BRUCE, A., Animal Law in Australia: An Integrated Approach (LexisNexis Butterworths, 2nd ed 2018).

- CARENZI, C., Animal welfare: review of the scientific concept and definition (2009) 8(1) Ital.J.Anim.Sci. 21-30.

- CAULFIELD, M., Handbook of Australian Animal Cruelty Law (Animals Australia, 2009).

- CAULFIELD, M., Animals in Australia (Vivid Publishing, 2018).

- CAULFIELD, M., How the Australian animal use industry employs arguments against anthropomorphism, coupled with bad science, to skew animal welfare law (2017) 6 Animal Studies Journal 155.

- CAULFIELD, M.- CAMBRIDGE, H., The Questionable Value of Some Science-Based 'Welfare' Assessments in Intensive Farming (2008) 86 Australian Veterinary Journal 446.

- CEBALLOS, M.C. et al, Environmental enrichment for rabbits reared in cages reduces abnormal behaviours and inactivity (2017) 46(6) Animal Production 1088.

- CHAPMAN, J.A.- FLUX, J.E.C., Rabbits, Hares and Pikas: Status Survey and Conservation Action Plan (International Union for Conservation of Nature and Natural Resources, 1990) 2.

- COMAN, B., Tooth and Nail: The Story of the Rabbit in Australia (Text Publishing, 1999).

- CORNELISSEN, J.M.R et al, Report 524: Brief of Requirements of the Rabbit (2011) Wageningen UR Livestock Research.

- COWIE, M., Farmed Rabbit Processing - Improving returns (2010) 09/168 Rural Industries Research and Development Corporation Publication 1.

- DAWKINS, M., Through animal eyes: what behaviour tells us (2006) 100 Applied Animal Behaviour Science 4. 
-DAWKINS, M., Animal welfare and efficient farming: is conflict inevitable? (2017b) 57 Animal Production Science 201.

- DAWKINS, M., Through animal eyes: What behaviour tells us (2006) 100 Applied Animal Behaviour Science 4.

- DEMELLO, M.- DAVIS, S.E., Stories Rabbits Tell (Lantern Books, 2003).

- DIVINCENTI, L. JR- REHRIG, A.N, The Social Nature of European Rabbits (Oryctolagus cuniculus) (2016) 55(6) J Am Assoc Lab Anim Sci. 729.

- DIXON, L.M., The effects of spatial restriction on the behavior of rabbits (Oryctolagus cuniculus) (2010) 5(6) Journal of Veterinary Behaviour 302.

- DUNCAN, I.J.H, The Changing Concept of Animal Sentience (2006) 100 Applied Animal Behaviour Science 11.

- DUNCAN, I.J.H, Welfare is to do with what animals feel (1993) Jrnl of Agricultural and Environmental Ethics.

- EADY, S., Farmed Rabbits in Australia (2003) 02/144 Rural Industries Research and Development Corporation Publication.

- EADY, S., A Production System for Australian Farmed Rabbits (2005) 05/038 Rural Industries Research and Development Corporation Publication.

- EATHER, W.- COTTLE, D., The Rabbit Industry in South-East Australia, 1870-1970 (Paper presented at the 14th Biennial Labour History Conference, Melbourne, 2015).

- ECK, S., Report on minimum standards for the protection of farm rabbits (2017) A8-0011/2017 European Parliament Plenary Sitting.

- ELLIS, E., Principles and Practice of Australian Law (Thomson Reuters Australia, Edition 3, 2013).

- ELLIS, E., Making Sausages and Law: The Failure of Australian Animal Welfare Laws to Protect both Animals and Fundamental Tenets of Australia's Legal System (2010) 4 Australian Animal Protection Law Journal 6.

- ELLIS, E., Bearing the Burden: Shifting Responsibility for the Welfare of the Beast (2013) 11 Macquarie Law Journal 39.

- FARM ANIMAL WELFARE COUNCIL, Farm Animal Welfare in Great Britain: Past, Present and Future (2009).

- FAVRE, D., 'The Degree of Legal Regulation' in Mike Radford (ed), Animal welfare law in Britain (Oxford University Press, 2001) 123.

- FOSTER, M., Australian Farmed Rabbit Prospects for Industry Development (1999) 99/89 Rural Industries Research and Development Corporation Publication.

- FOSTER, M., Emerging animal and plant industries: their value to Australia (2014) 14/069 Rural Industries Research and Development Corporation Publication.

- FRANKLIN, A., Human-Nonhuman Animal Relationships in Australia: An Overview of Results from the First National Survey and Follow-up Case Studies 2000-2004 (2007) 15 Society and Animal 9.

- FRASER, D. et al, A Scientific Conception of Animal Welfare that Reflects Ethical Concerns (1997) 6 Animal Welfare 187.

- FRASER, D., A 'practical' ethic for animals (2012) 25 Journal of Agricultural and Environmental Ethics 721.

- FRASER, D., Understanding animal welfare (2008) 50:S1 Acta Veterinaria Scandinavica.

- FUENTES, G.C.- NEWGREN, J., Physiology and Clinical Pathology of Laboratory New Zealand White Rabbits Housed Individually and in Groups (2008) 47(2) J Am Assoc Lab Anim Sci 35.

- GARNER, R., Political ideology and the legal status of animals' (2002) 8 Animal Law 77.

- GARNER, R., Animals, Ethics and Public Policy (2010) 81(1) The Political Quarterly 126.

- GARNER, R., The Politics of Animal Rights (2008) 3 British Politics 118.

- GLASGOW, D., The Law of the Jungle: Advocating for Animal in Australia (2008) 13 Deakin Law Review 181.

- GOODFELLOW, J., Animal welfare regulation in the Australian agricultural sector: a legitimacy maximising analysis ( $\mathrm{PhD}$ thesis, Macquarie University, 2015).

- GORDON, J.- GARRET, D., Rabbit farming: An evaluation of the Crusader R\&D program (2003) 03/144 Rural Industries Research and Development Corporation 1.

- GRAY, G., Historical perspective of the legalisation of keeping pet rabbits in Western Australia, Vertebrate Pest Research Services (online) <http://members.iinet.net.au/ rabbit/waprhist.htm>.

- GRUEN, L. (ed), The Ethics of Captivity (Oxford University Press, 2014). 
- HARRISON, H. et al, Case Study Research: Foundations and Methodological Orientations (2017) 18(1) Qualitative Social Research Forum 13.

- HARRISON, R., Animal Machines: The New Factory Farm Industry (Vincent Stuart Publishers, 1964).

- HEMSWORTH, P., Scientific assessment of animal welfare (2015) 63 New Zealand Veterinary Journal 24.

- HERZOG, H., Some We Love, Some We Hate, Some We Eat (Harper Perennial, 2010)

- HERZOG, H., 'The Moral Status of Mice' (1988) 43(6) American Psychologist 473.

- HOY, S., Guidelines for minimum standards on rabbit housing in Germany (2008) Ethology and Welfare 1183.

- JAMIESON, P., Duty and the Beast: The Movement in Reform of Animal Welfare Law (1991) 16 University of Queensland Law Journal 238.

- KREMPELS, D., Pre- and Post-operative care of Rabbits (3 January 2011) University of Miami Department of Biology $<$ http://www.bio.miami.edu/hare/opcare.html $>$.

- KREMPELS, D., GastroIntestinal Stasis, The Silent Killer (June 2005) University of Miami Department of Biology $<$ http://www.bio.miami.edu/hare/ileus.html $>$.

- LEBAS, F. et al, 'The rabbit husbandry, health and production' (1997) 21 Food and Agriculture Organisation of the United Nations.

- LEXISNEXIS, Halsbury's Laws of Australia, vol 1(2), 20 Animals, '1 Property in Animals' [20-50].

- LOUGHNAN, S. et al, 'The role of meat consumption in the denial of moral status and mind to meat animals' (2010) 55 Appetite 156.

- MARAI, I. M.- RASHWAN, A.A., Rabbits behavioural response to climatic and managerial conditions - a review (2004) 47(5) Arch. Tierz. Dummerstorf 469.

- McCULLOCH, S.P, A critique of FAWC's Five Freedoms as a framework for the analysis of animal welfare (Royal Veterinary College, London,2012).

- McEWAN, A.B., The Concept of Violence: A Proposed Framework for the Study of Animal Protection Law and Policy (PhD Thesis, The Australian National University, 2016).

- McEWAN, A., Martha Nussbaum's Capabilities Approach for Non-Human Species: A Preliminary Critique (2010) 4 Australian Animal Protection Law Journal 64.

- McEWAN, A.- SKANDAKUMAR, K., The Welfare of Greyhounds in Australian Racing: Has the Industry Run its Course? (2011) 5 Australian Animal Protection Law Journal 53.

- McEWEN, G., Animal Law: Principles and Frontiers (2011).

- McINERNEY, J., Animal Welfare Economics and Policy (2004) Report on a study undertaken for the Farm and Animal Health Economics Division of Defra.

- MELLOR, D., Updating Animal Welfare Thinking: Moving beyond the "Five Freedoms" towards "A Life Worth Living" (2016) 6 Animals 21.

- MELLOR, D.- BEAUSOLEIL, N., Extending the 'Five Domains' model for animal welfare assessment to incorporate positive welfare states (2015) 24 Animal Welfare 241.

- MONNEROT, M. et al, Rabbit and man: genetic and historic approach (1994) 26 (1) Genet Sel Evol 178.

- NEUMANN, G., Review of the Australian Model Codes of Practice for the Welfare of Animals (2005) Geoff Neumann and Associates.

- NODARI, R. et al, Rabbit welfare during electrical stunning and slaughter at a commercial abattoir (2009) 17 World Rabbit Sci.163.

- NSW Food Authority, 'Management responsibilities for animal welfare at poultry and rabbit abattoirs' General Circular (2012) 1-3.

- O’SULliVAN, S., Animals, Equality and Democracy (Palgrave MacMillan, 2011).

- OLAWUMI, S., Comparative Study on Rabbit Breeds for Post Weaning Growth Traits in the Humid Tropics of Nigeria (2014) 2(1) Global Journal of Animal Scientific Research 45.

- OGLESBEE, B., Blackwell's Five-Minute Veterinary Consult: Small Mammal (John Wiley \& Sons, 2nd Ed 2011).

- PRICE, E., Behavioral development in animals undergoing domestication (1999) 65 Applied Animal Behaviour Science 246.

- RADFORD, M., Animal Welfare Law in Britain: Regulation and Responsibility (Oxford University Press, 2001).

- REGAN, T., The Case for Animal Rights (Routledge and Kegan Paul, 1983).

- REINHARDT, V.- REINHARDT, A., Variables, Refinement and Environmental Enrichment for 
Rodents and Rabbits kept in Research Institutions (Animal Welfare Institute, 2006) 7.

- RILEY, S., Animal Law Case Book (UTS 1st ed).

- ROELOFS, S., Domestic Rabbit Welfare: Welfare issues surrounding a multi-purpose animal (Master's Thesis, Utrecht University, 2016).

- SCIENTIFIC PANEL ON ANIMAL HEALTH AND WELFARE, The Impact of the current housing and husbandry systems on the health and welfare of farmed domestic rabbits (2005) 267 The EFSA Journal.

- SERPELL, J.A., Sheep in wolves' clothing? Attitudes to animals among farmers and scientists, in Francine L. Dolins (ed.), Attitudes to Animals: Views in Animal Welfare (Cambridge University Press, 1999).

- SHARPE, T., Standard Operating Procedure GEN001: Methods of euthanasia (2012) 13 Invasive Animals CRC 1.

- SHIM-PRYDON, G. et al, New Animal Products New uses and markets for by-products and coproducts of crocodile, emu, goat, kangaroo and rabbit (2007) 06/117 Rural Industries Research and Development Corporation Publication 1.

- SINGER, P., Animal Liberation (Pimlico, 2nd ed, 1995).

- Singer, Peter, Ethics into Action, Henry Spira and the Animal Rights Movement (Rowaman \& Littlefield, 1998).

- SINGER, P.- MASON, J., The ethics of what we eat (Text Publishing Co,2006) 19-39, 41-48.

- Slooten, Lynn, Design for the well-being of rabbits (Master's Thesis, Delft University of Technology, 2014).

- SOBEY, W.R., Protecting Domestic Rabbits Against Myxomatosis in Australia and the Problems Associated with it Past and Present (Paper presented at Recent Advances in Animal Nutrition, 1981) $<$ http://livestocklibrary.com.au/handle/1234/19383>.

- SPIRA, H., Fighting to win, in Peter Singer (ed), In Defense of Animals ( Blackwell, 1985) 194-208.

- SUEN, W. W. et al, Experimental West Nile Virus Infection in Rabbits: An Alternative Model for Studying Induction of Disease and Virus Control (2015) 4 Pathogens 529.

- SUNSTEIN, C.R.- NUSSBAUM, M. (eds), Animal Rights: Current Debates and New Directions (Oxford University Press, 2004).

- SEVILLANO, V.- FISKE, S.T., Animals as Social Objects: Groups, Stereotypes, and Intergroup Threats (2016) European Psychologist 15.

- TAYLOR, N.- SIGNAL, T., Pet, Pest, Profit: isolating differences in attitudes towards the treatment of animals (2009) 22 Anthrozoos 134.

- TAYLOR, G.- KRUGER, I., Farming meat rabbits in NSW. Profitable and Sustainable Primary Industries (NSW Department of Primary Industries PRIMEFACT 104, 2004).

- TAYLOR, G.B., One man's philosophy of welfare (1972) 91 Vet Rec 426.

- TOROSYAN, G.F.- LOWE, B., Nobody Wants to Eat Them Alive: Ethical Dilemmas and Dual Media Narratives on Domestic Rabbits as Pets and Commodity (2013) 2012(9) Proceedings of the New York State Communication Association 7.

- VERGA, M. et al, 'Welfare aspects in rabbit rearing and transport' (2009) 8(1) Italian Journal of Animal Science 193.

- VERGA, M., Intensive rabbit breeding and welfare: development of research, trends and applications (2000) Proceedings of the 7th World Rabbit Congress 491.

- VOICELESS: the animal protection institute, The Animal Law Toolkit (2009).

- Webster, John, 'Animal Welfare: Freedoms, Dominions and "A Life Worth Living" (2016) 6(6) Animals 35.

- WEBSTER, A.J.F., The science of Animal Welfare $<$ http://citeseerx.ist.psu.edu/viewdoc/download?doi=10.1.1.1001.4358\&rep=rep1\&type=pdf $>$

- WHITE, S., Regulation of Animal Welfare in Australia and the Emergent Commonwealth: Entrenching the Traditional Approach of the States and Territories or Laying the Ground for Reform? (2007) 35 Federal Law Review 347.

- WHITE, S., Legislating for Animal Welfare: Making the Interests of Animals Count (2003) 28(6) Alternative Law Journal 277.

- WILKINS, A.M. et al, Factors affecting the Human Attribution of Emotions toward Animals (2015) 28:3 Anthrozoös 367.

- WILLIAMS, K. et al, Managing Vertebrate Pests: Rabbits (Australian Government Publishing Service, 
Canberra, 1995).

- WILLIAMS, S.- PATTINSON, R., Animal Industries Five Year RD\&E Plan 2013-2018 (2014) 14/055 Rural Industries Research and Development Corporation Publication.

\section{Legislation}

\section{Legislation}

- Australian Capital Territory

Animal Welfare Act 1992 (ACT)

Pest Plants and Animals Act 2005 (ACT)

- Queensland (Qld)

Animal Care and Protection Act 2001 (Qld)

Biosecurity Act 2014 (Qld)

Land Protection (Pest and Stock Route Management) Act 2002 (Qld)

Rabbit Act of 1880 (Qld)

- New South Wales (NSW)

Animal Research Act 1985 (NSW)

Animal Research Regulation 2010 (NSW).

Biosecurity Act 2015 (NSW)

Biosecurity Amendment (Pest Management) Regulation 2018 (NSW)

Companion Animal Act 1998 (NSW)

Companion Animals Regulation 2008 (NSW)

Crimes Act 1900 (NSW)

Exhibited Animals Protection Act 1986 (NSW)

Exhibited Animals Protection Regulation (NSW) 2010

Food Act 2003 (NSW)

Food Regulation 2015 (NSW)

Game and Feral Animal Control Act 2002 (NSW)

Local Lands Services Act 2013 (NSW)

Meat Industry Act 1978 (NSW)

Meat Industry Amendment Act 1998 (NSW)

Pastures and Stock Protection Act 1880 (NSW)

Pastures Protection Act 1912 (NSW)

Pastures Protection Act 1934 (NSW)

Prevention of Cruelty to Animals Act 1979 (NSW)

Prevention of Cruelty to Animals Regulations 2012 (NSW)

Rabbit Destruction Ordinance 1919 (NSW)

Rabbit Nuisance Act 1883 (NSW)

Rabbit Act 1890 (NSW)

Rural Lands Protection Act 1989 (NSW)

Rural Lands Protection Regulation 1990 (NSW)

- Northern Territory (NT)

Animal Welfare Act 1999 (NT)

Territory Parks and Wildlife Conservation Act 2006 (NT)

- South Australia (SA)

Natural Resources Management Act 2004 (SA)

Prevention of Cruelty to Animals Act 1985 (SA)

Rabbit Destruction Act 1875 (SA)

- Tasmania

Animal Welfare Act 1993 (Tas)

Rabbit Destruction Act 1871 (Tas)

Vermin Control Act 2000 (Tas)

- Victoria (Vic)

Catchment and Land Protection Act 1994 (Vic)

Domestic Animal Act 1994 (Vic)

Domestic Animals Regulations 2015 (Vic)

Meat Industry Act 1993(Vic) 
Meat Industry (Amendment) Regulations 1998 (Vic)

Meat Industry Regulations 2015 (Vic)

Prevention of Cruelty to Animals Act 1986 (Vic)

Prevention of Cruelty to Animals (further amendment) Regulation 2004 (Vic)

Prevention of Cruelty to Animals Regulation 2008 (Vic)

Rabbit Nuisance Suppression Act 1878 (Vic)

- Western Australia (WA)

Agriculture and Related Resources Protection Act 1976 (WA)

Agriculture and Related Resources Protection (Declared Animals) Regulations 1985 (WA)

Agriculture Protection Board Act 1950 (WA)

Animal Welfare Act 2002 (WA)

Animal Welfare (General) Regulations 2003 (WA)

Animal Resources Authority Act 1981 (WA)

Biosecurity and Agriculture Management Act 2007 (WA)

Destruction of Rabbits Act 1883 (WA)

Food Regulations 2009 (WA)

Western Australian Meat Industry Authority Act 1976 (WA)

\section{Other Legislative Instruments}

- Animal Health Australia, Australian Animal Welfare Standards and Guidelines-Land Transport (Commonwealth of Australia, Edition 1, Version 1.1, 2012).

- Animal Health Australia, Australian Animal Welfare Standards and Guidelines - Sheep (Edition One, 2014).

- Animal Health Australia, Australian Animal Welfare Standards and Guidelines - Cattle (Edition One, 2014).

- Commonwealth Scientific and Industrial Research Organisation, Australian Standard for Hygienic Production of Rabbit Meat for Human Consumption, SCARM Report 59, AS 4466:1997(Commonwealth of Australia, 1997).

- Commonwealth Scientific and Industrial Research Organisation, Australian Standard for Hygienic Production of Rabbit Meat for Human Consumption, SCARM Report 59, AS 4466:1998 (Commonwealth of Australia, 1998).

- Commonwealth Scientific and Industrial Research Organisation, Australian Standard for the Hygienic Production and Transportation of Meat and Meat Products for Human Consumption FRSC Technical Report No 3 AS 46962007 (Commonwealth of Australia, 2007).

- Commonwealth Scientific and Industrial Research Organisation (CSIRO) and Primary Industries Standing Committee (Cth), Model Code of Practice for the Welfare of Animals: Animals at Saleyards (PISC Report Series 31, 1991).

- CSIRO Publishing and Primary Industry Standing Committee (Cth), Model Code of Practice for the Welfare of Animals: Intensive Husbandry of Rabbits (Primary Industries Report Series 33, 2003).

- Department of Agriculture (NSW) ARRP Guideline 18: Guidelines for the Housing of Rabbits in Scientific Institutions, 2003 (State of New South Wales, 2003).

- Department of Agriculture (Vic), Code of Practice for the Intensive Husbandry of Rabbits (State of Victoria).

- Department of Agriculture (Vic) Code of practice for the use of animals from municipal pounds in scientific procedures, 1988 (State of Victoria, 1988).

- Department of Agriculture (Vic),Code of Practice for the Operation of Pet shops (State of Victoria).

- Department of Agriculture and Water Resources, Australian Animal Welfare Strategy-AAWS and National Implementation 2010-14, $<$ http://www.agriculture.gov.au/animal/welfare/aaws/australian-animal-welfare-strategy-aaws-andnational-implementation-plan-2010-14>.

- Department of Economic Development, Jobs, Transport and Resources (Vic) Code of Practice for the Operation of Breeding and Rearing Businesses 2018 (State of Victoria, 2018).

- Department of Primary Industries (Vic) Code of Practice for the Housing and Care of Laboratory Mice, Rats, Guinea Pigs and Rabbits, 2004 (State of Victoria, 2004).

- Department of Primary Industries (NSW), Animal Welfare Code of Practice - Breeding Dogs and Cats 2009 (State of New South Wales, 2009) 
- Department of Primary Industries (NSW), Animal Welfare Code of Practice: Animals in Pet Shops 2008 (State of New South Wales, 2008).

- Department of Primary Industries (NSW), NSW Animal Welfare Code of Practice No 1 - Companion animal transport agencies, 1996 (State of New South Wales, 1996).

- Department of Primary Industries (NSW), Rabbit farming: Planning and development control guidelines, environmental planning, section 7.1 (State of New South Wales, 1996). $<$ https://www.dpi.nsw.gov.au/animals-and-livestock/other-animals/rabbit-farming-planning>.

- Department of Local Government and Regional Development (WA) The Code of practice for keeping of Rabbits in Western Australia, 2003 (State of Western Australia, 2003)

- National Health and Medical Research Council, Australian Code of Practice of the Care and Use of Animals for Scientific Purposes 7th Edition 2004 (National Health and Medical Research Council, 7th ed, 2004).

- National Health and Medical Research Council, Australian Code of Practice of the Care and Use of Animals for Scientific Purposes 8th Edition 2013 (National Health and Medical Research Council, 8th ed, 2013).

- Primary Industries Standing Committee, Parliament of Australia, Model Code of Practice for the Welfare of Animals: Pigs (PISC Report 92, Commonwealth of Australia, 3rd Edition, 2008) Appendix 3.

\section{Other (Parliamentary Debates, News Media, Websites)}

\section{Parliamentary Debates}

- New South Wales, Parliamentary Debates, Legislative Council, 20 September 2016, 1224 (Melinda Pavey) $<$ https://www.parliament.nsw.gov.au/Hansard/Pages/HansardResult.aspx\#/docid/HANSARD$1323879322-93143>$.

\section{News Media}

- ARROYO, A., Protestors Attack Whole Foods For Selling Rabbit Meat' Eater Denver (online) 3 April $2015<$ https://denver.eater.com/2015/4/3/8337615/protest-rabbit-meat-whole-foods-boulder>.

- ATKINS, J., Australia's Largest Rabbit Farm, ABC NorthCoast NSW (online) 2 October 2008 $<$ http://www.abc.net.au/local/stories/2008/10/07/2380383.htm>.

- BECKER, J., Calicivirus wipes out half of rabbit farmer's stock in southern NSW, ABC News Rural 30 October $2015<\mathrm{http}: / /$ www.abc.net.au/news/rural/2015-10-30/calicivirus-wipes-out-rabbit-farmin-southern-nsw/6900080>.

- Channel Seven, The disturbing reality behind caged rabbits bred for their meat, 7News, 18 September 2016 (Bryan Seymour) <https://au.news.yahoo.com/the-disturbing-reality-behind-caged-rabbitsbred-for-their-meat-32652779.html\#page1>.

- EDWARDS, A., Rabbit meat disappearing from consumers' tables as farmers struggle with spiralling costs, 21 April 2014 ABC News (online) <http://www.abc.net.au/news/2014-04-21/rabbit-meatdisappearing-from-australian-tables/5400586>.

- LANE, K., Hop to it - its dinner time, Sydney Morning Herald (online) 23 May 2010 $<$ https://www.smh.com.au/entertainment/hop-to-it---its-dinner-time-20100522-w32v.html>

- MARX, A., Investors' funds down the rabbit hole, The Courier Mail (online) 27 September $<2010 \mathrm{https}$ :/www.couriermail.com.au/business/kyogle-rabbit-farm-up-for-sale/newsstory/828cd1b96c1f639a2f38cb7e5ad7eb93?sv=bdc7656df7ff977d1036b3d9f50b69b2>.

- RYAN, C., Whole Foods Market halts sale of rabbit, GlobalMeat News (online) 20 September 2015 $<$ https://www.globalmeatnews.com/Article/2015/09/21/Whole-Foods-Market-halts-sale-of-rabbit>.

- STAIGHT, K., Breeding Rabbits, ABC Landline (online) 9 November $<$ http://www.abc.net.au/tv/programs/landline/old-site/ content/2008/s2736433.htm>.

- TWOMEY, S., Akubra dumps Australian rabbit suppliers for Russian rabbit skins, The Weekly Times (online) 8 July $2015<$ https://www.weeklytimesnow.com.au/agribusiness/sheep/akubra-dumpsaustralian-rabbit-suppliers-for-russian-rabbit-skins/newsstory/c28e 7fcf4e32d8acdcfa27f8f47c5768; accessed $>$.

- TWOMEY, S., Farmed rabbit on the fall in Australia as producer numbers drop, The Weekly Times 
(online) $2014<$ http://www.weeklytimesnow.com.au/agribusiness/farmed-rabbit-on-the-fall-inaustralia-as-producer-numbers-drop/ news-story/0823d9540dce1951d15314622591d251>.

- TYNE, L., Saved by the poo: Rabbit manure the saviour for Western Australia's only commercial rabbit producer, ABC News Rural (online) 23 March $2017<\mathrm{http} / /$ www.abc.net.au/news/2014-0421/rabbit-meat-disappearing-from-australian-tables/5400586>

\section{Websites}

- Alex Greenwich Independent Member For Sydney, Rabbit Cruelty (2016) $<$ http://www.alexgreenwich.com/rabbit_cruelty>.

- Animal Liberation NSW, Rabbits (2017) <https://www.animal-lib.org.au/campaigns/animalsforfood/rabbits>.

- Animal Ethics Infolink, Policies and Guidelines <https://www.animalethics.org.au/policies-andguidelines>.

- Animal Health Australia, About Us (19 July 2018) <https://www.animalhealthaustralia.com.au/whowe-are/company-profile/s.

- Animal Medicines Australia, Pet Ownership in Australia 2016 (2016)<http://animalmedicinesaustralia.org.au/wp-content/uploads/2016/11/AMA_Pet-Ownershipin-Australia-2016-Report_sml.pdf>.

- Australian Government, Federation <https://www.australia.gov.au/about-government/howgovernment-works/federation>.

- Australian Veterinary Association, Rabbit Calicivirus in Australia $<$ https://www.ava.com.au/rabbitcalicivirus>.

- Australian Bureau of Statistics Counts of Australian Businesses, including Entries and Exits, Jun 2007 to Jun 2009.

- Aussie Farms, The Aussie Farms Repository $<$ https://www.aussiefarms.org.au/facilities/food/rabbits>.

- Australian Pork, Industry Focus: Housing < http://australianpork.com.au/industry-focus/animalwelfare/housing/>.

- Cambridge English 'Oxymoron' $<$ https://dictionary.cambridge.org/dictionary/english/oxymoron>.

- Centre for Invasive Species Solution, 'Rabbit Legislation in Australia' $<$ https://www.pestsmart.org.au/pestsmart-factsheet-rabbit-legislation-in-australia/>.

- Centre for Invasive Species Solutions, Rabbit Biocontrol in Australia $<$ https://www.pestsmart.org.au/rabbit-biocontrol-in-australia-key-facts/>.

- Centre for Invasive Species Solution, RAB002: Ground baiting of rabbits with 1080, $<$ https://www.pestsmart.org.au/ground-baiting-of-rabbits-with-1080/>.

- Centre for Invasive Species Solution, Model code of practice for the humane control of rabbits $<$ https://www.pestsmart.org.au/wp-content/uploads/2012/09/rabbitCOP2012.pdf $>$.

- Collins English dictionary

$<$ https://www.collinsdictionary.com/dictionary/english/ethology $>$.

- Cross Roads Rabbitry, New Zealand Whites <http://www.crossroadsrabbitry.com/about-newzealand-white-rabbits/>.

- CSIRO Publishing, Food \& Agriculture:Livestock Codes <http://www.publish.csiro.au $>$.

- Department of Environment and Energy, Threat abatement plan for competition and land degradation by rabbits <https://www.environment.gov.au/system/files/resources/bf9352c2-35ae-4a80-882896de630731a9/files/tap-rabbit-background-2016.docx>.

- Ecologistics, 'Rabbit in Australia' <http://www.ecologistics.com.au/rabbits-in-australia/>.

- Farmstyle Australia, Farming Meat Rabbits: An Introduction <http://farmstyle.com.au/news/farmingmeat-rabbits-introduction>.

- Frances Harcourt Brown, Myxomatosis <https://www.harcourt-brown.co.uk/articles/infectiousdisease/myxomatosis $>$.

- Freedom for Farmed Rabbits Inc., Cruelty Evidence $<$ http://www.freedomforfarmedrabbits.com.au/farms/cruelty-evidence/>.
- Government of Western
Australia, Western Australian
Legislation

$<$ https://www.legislation.wa.gov.au>.

- Invasive Animals Cooperative Research Centre, The economic impacts of vertebrate pests in Australia 
$<$ https://www.pestsmart.org.au/wp-content/uploads/2010/03/IACRC_EconomicImpactsReport.pdf $>$.

- JADE (Judgments and Decisions Enhanced) What is JADE? <https://jade.io/t/home >.

- Kyogle Real Estate, $\quad$ Small Abattoir $<$ http://www.kyogle.com.au/documents/RABBITPDF.pdf $>$.

- New South Wales Government, NSW Legislation <https://www.legislation.nsw.gov.au>.

- Merck Sharp \& Dohme Corporation Veterinary Manual, Description and Physical Characteristics of Rabbits <https://www.msdvetmanual.com/all-other-pets/rabbits/description-and-physicalcharacteristics-of-rabbits>.

- Parliamentary Education Office, Legal Fact Sheets <https://www.peo.gov.au/learning/factsheets.html>.

- Parliament of Australia, Making laws

$<$ https://www.aph.gov.au/About_Parliament/House_of_Representatives/Powers_practice_and_proced ure/00_-_Infosheets/Infosheet_7_-_Making_Laws>.

- Pet Med, How Long Will My Rabbit Live <https://www.petmd.com/rabbit/care/how-long-will-myrabbit-live>.

- Queensland Department of Agriculture and Fisheries, Can I Have a Pet Rabbit $<$ https://www.daf.qld.gov.au/_data/assets/pdf_file/0009/57780/IPA-Keeping-Rabbits-As-Pets-

PA15.pdf $>$.

- RSPCA, End the Battery Cage <https://www.rspca.org.au/campaigns/end-the-battery-cage-publicconsultation>.

- RSPCA, Five freedoms for animals (12 Jun 2009) <http://kb.rspca.org.au/five-freedoms-foranimals 318.html>.

- RSPCA, What is the RSPCA's view on farming rabbits for meat? (19 September 2016) $<$ http://kb.rspca.org.au/what-is-the-rspcas-view-on-farming-rabbits-for-meat_357.html>.

- RSPCA, Breakthrough research finds $84 \%$ of Australians want to end the battery cage (26th November 2017) < https://www.rspca.org.au/media-centre/news/2017/breakthrough-research-finds84-australians-want-end-battery-cage $>$.

- The International Union for Conservation of Nature, Species $<$ https://www.iucn.org/theme/species $>$.

- The Public Interest Advocacy Centre, Australian legal system $<$ http://www.utas.edu.au/ data/assets/pdf file/0017/334232/aust leg syst 601.pdf $>$

- Victorian Legislation and Parliamentary Documents, Victorian Law Today Library $<$ http://www.legislation.vic.gov.au $>$.

- World Organisation for Animal Health, A new definition for the Terrestrial Animal Health Code: 'animal welfare $<$ http://www.oie.int/doc/ged/D5517.pdf $>$.

-Zoetis, RCD Cyclap Vaccine <https://www.zoetis.com.au/product-class-new/vaccines/cylap-rcdvaccine.aspx>. 


\section{Appendices}

Appendix 1The legislative process
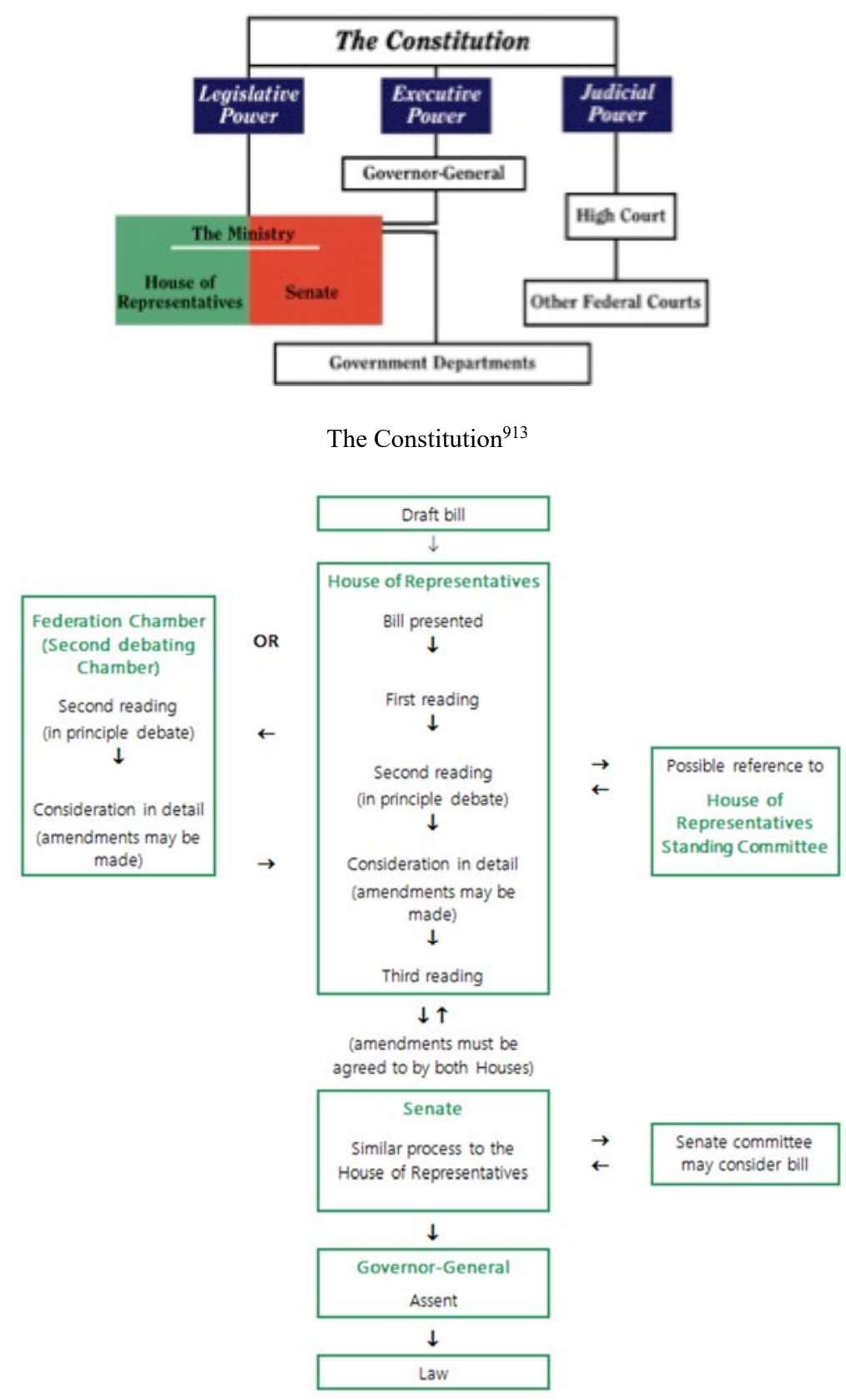

Bills (proposed laws) may be introduced first in either the House of Representatives or the Senate but must be considered by each House in turn. ${ }^{914}$

913 The Constitution available online at:

https://www.aph.gov.au/About_Parliament/Work_of_the_Parliament/Forming_and_Governing_a_Nation/parl [Accessed 20 March 2018].

914 Parliament of Australia. 2012. Infosheet 7 - Making laws. [ONLINE] Available at:

https://www.aph.gov.au/About_Parliament/House_of_Representatives/Powers_practice_and_procedure/00_-

_Infosheets/Infosheet_7_-_Making_Laws. [Accessed 20 March 2018].

194 Derecho Animal. Forum of Animal Law Studies, vol. 10/2 


\section{Appendix 2A: Definition of 'Animal' under which 'Rabbit' falls in NSW Statutes}

\begin{tabular}{|c|c|}
\hline Statute & Definition of Animal \\
\hline $\begin{array}{l}\text { Prevention of Cruelty to Animals Act } 1979 \\
\text { (NSW) }\end{array}$ & $\begin{array}{l}\text { s 4: "animal" means a vertebrate animal, including a mammal, } \\
\text { bird, reptile, amphibian or fish, but does not include a human being }\end{array}$ \\
\hline & $\begin{array}{l}\text { s 4: "Stock animal means an animal which belongs to the class of } \\
\text { animals comprising cattle, horses, sheep, goats, deer, pigs, poultry } \\
\text { and any other species of animal prescribed for the purposes of this } \\
\text { definition". }\end{array}$ \\
\hline Animal Research Act 1985 (NSW) & $\begin{array}{l}\text { s 3: animal means a vertebrate animal, and includes a mammal, } \\
\text { bird, reptile, amphibian and fish, but does not include a human } \\
\text { being. }\end{array}$ \\
\hline $\begin{array}{l}\text { Australian code for the care and use of } \\
\text { animals for scientific purposes } 8^{\text {th }} \text { edition } \\
\text { (2013) }\end{array}$ & $\begin{array}{l}\text { Animal: any live non-human vertebrate (that is, fish, amphibians, } \\
\text { reptiles, birds and mammals encompassing domestic animals, } \\
\text { purpose-bred animals, livestock, wildlife) and cephalopods. }\end{array}$ \\
\hline Food Act 2003 (NSW) & $\begin{array}{l}\text { Part 1, section 4: animal includes an amphibian, bird, crustacean, } \\
\text { fish, mollusc or reptile. }\end{array}$ \\
\hline Food Regulation 2015 (NSW) & S76 (1) Animal: Abattoir animal (b) rabbit \\
\hline Companion Animal Act 1998 (NSW) & $\begin{array}{l}\text { Section 5: companion animal means each of the following: } \\
\text { (a) a dog, } \\
\text { (b) a cat, } \\
\text { ( (c) any other animal that is prescribed by the regulations as a } \\
\text { companion animal. }\end{array}$ \\
\hline Crimes Act 1900 (NSW) & $\begin{array}{l}\text { s } 530 \text { (3): animal means a mammal (other than a human being), a } \\
\text { bird or a reptile. }\end{array}$ \\
\hline Local Land Services Act 2013 (NSW) & $\begin{array}{l}\text { The pest control order referenced under section } 130(1)(\mathrm{b}) \text { of the } \\
\text { Act is the Local Land Services (Rabbits) Pest Control Order } 2016 . \\
\text { Under NSW Government Gazette No } 60 \text { of } 22 \text { July 2016: section } \\
\text { 6, declaration of rabbit to be pest on controlled land. Section 5: } \\
\text { controlled land: all land in NSW. Rabbit means any animal of } \\
\text { the species Oryctolagus cuniculus. }\end{array}$ \\
\hline $\begin{array}{l}\text { Game and Feral Animal Control Act } 2002 \\
\text { (NSW) }\end{array}$ & $\begin{array}{l}\text { s: Game animals for the purposes of this Act listed in schedule } \\
3 \text { of the Act. "Rabbit" listed in Schedule } 3 \text { Part } 2 \text { Non-indigenous } \\
\text { animals. }\end{array}$ \\
\hline
\end{tabular}

Appendix 2B: Rabbit Uses and Associated Welfare Regulatory Instruments (NSW)

\begin{tabular}{|c|c|c|}
\hline Rabbit Use & Regulatory Instrument & Voluntary Codes \\
\hline Rabbits Raised for food & $\begin{array}{l}\text { - Prevention of Cruelty to Animals Act } 1979 \text { (NSW) } \\
\text { - Prevention of cruelty to Animals regulations } 2012 \\
\text { (NSW) } \\
\text { - The Food Act } 2003 \text { (NSW) } \\
\text { - Food Regulation } 2015 \text { (NSW) } \\
\text { - Australian standard for hygienic production of rabbit } \\
\text { meat for human consumption (AS 4466:1998) } \\
\text { - Australian Standard for the hygienic production and } \\
\text { transportation of meat and meat products for human } \\
\text { consumption (AS 4696:2007) }\end{array}$ & $\begin{array}{l}\text { Model code of Practice for the } \\
\text { welfare of animals: Intensive } \\
\text { Husbandry of rabbits }\end{array}$ \\
\hline $\begin{array}{l}\text { Rabbits raised for } \\
\text { fur/pelt }\end{array}$ & $\begin{array}{l}\text { - Prevention of Cruelty to Animals Act } 1979 \text { (NSW) } \\
\text { - Prevention of cruelty to Animals regulations } 2012 \\
\text { (NSW) }\end{array}$ & $\begin{array}{l}\text { Model code of Practice for the } \\
\text { welfare of animals: Intensive } \\
\text { Husbandry of rabbits }\end{array}$ \\
\hline $\begin{array}{l}\text { Rabbits used for } \\
\text { research }\end{array}$ & $\begin{array}{l}\text { - Animal Research Act } 1985 \text { (NSW) } \\
\text { - Animal Research regulation } 2010 \text { (NSW) } \\
\text { - Australian code for the care and use of animals for } \\
\text { scientific purposes } 8^{\text {th }} \text { edition }(2013)\end{array}$ & $\begin{array}{l}\text { Guidelines for the housing of } \\
\text { rabbits in scientific institutions }\end{array}$ \\
\hline Rabbits as pets & $\begin{array}{l}\text { - Prevention of Cruelty to Animals Act } 1979 \text { (NSW) } \\
\text { - Prevention of cruelty to Animals regulations } 2012 \\
\text { (NSW) } \\
\text { - Codes of practice: }\end{array}$ & \\
\hline
\end{tabular}


- Animal Welfare Code of Practice-Animals in Pet Shops

- Animal Welfare Code of Practice No 1Companion Animal Transport Agencies

\section{Appendix 2C Rabbit Exemptions from Welfare Regulatory Instruments (NSW)}

\begin{tabular}{|c|c|}
\hline $\begin{array}{l}\text { Regulatory } \\
\text { Instrument }\end{array}$ & Exemptions \\
\hline $\begin{array}{l}\text { Prevention of } \\
\text { Cruelty to } \\
\text { Animals Act } 1979 \\
\text { (NSW) }\end{array}$ & 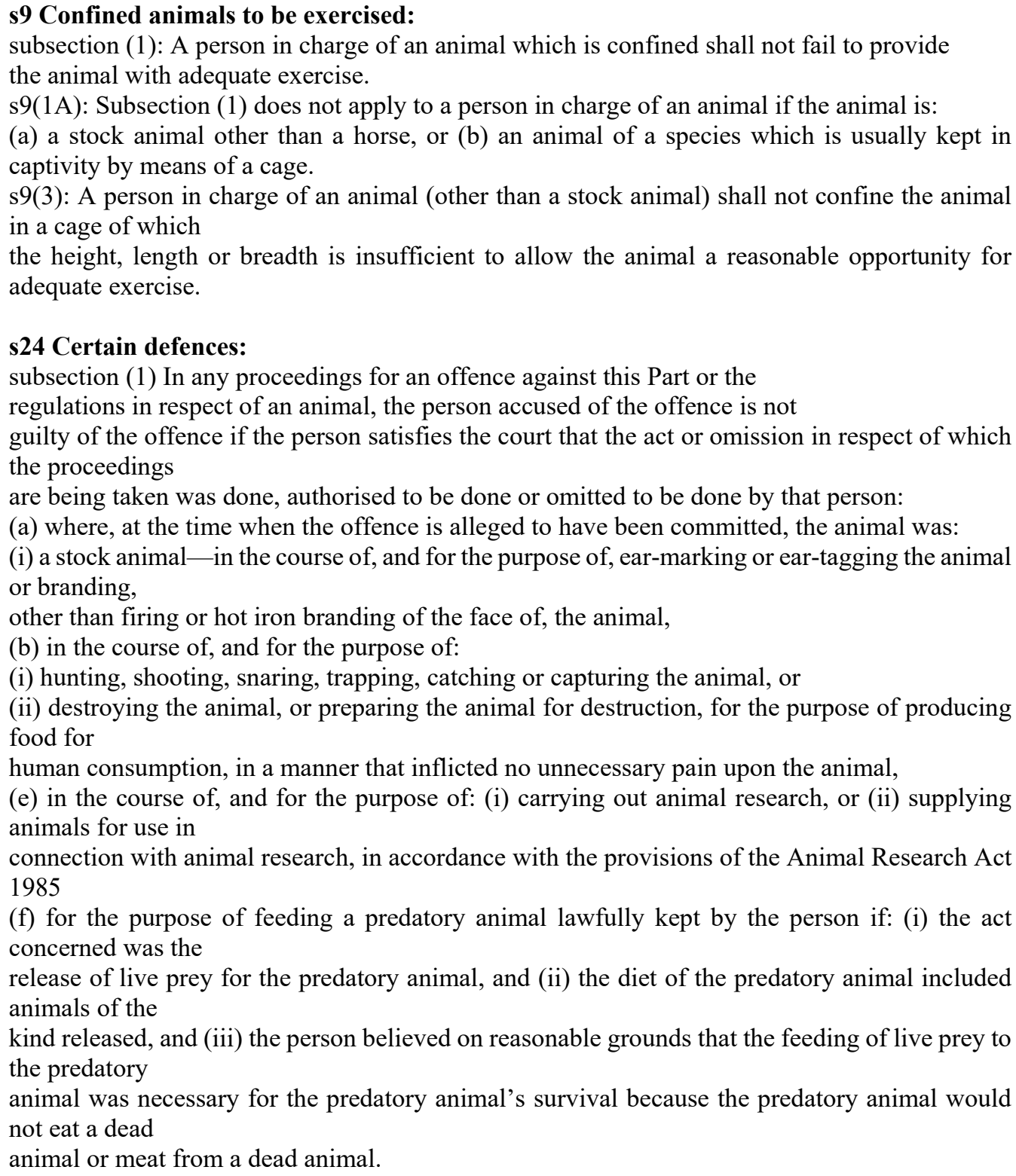 \\
\hline $\begin{array}{l}\text { Prevention of } \\
\text { cruelty to } \\
\text { Animals } \\
\text { regulations } 2012 \\
\text { (NSW) } \\
\text { Schedule1 codes } \\
\text { of practice: } \\
\text { Animal Welfare } \\
\text { Code of Practice: } \\
\text { Animals at pet } \\
\text { shops }\end{array}$ & $\begin{array}{l}\text { (8.3) EUTHANASIA 8.3.1 Standards } 8.3 .1 .2 \text { Euthanasia of dogs and cats must be performed } \\
\text { only by a veterinary surgeon or a person who is an authorised euthanasia technician. Standard of } \\
\text { euthanasia by veterinary staff only applies to dogs and cats. } \\
\text { 2.5 The sale, or keeping for sale, of an animal or animals in the following circumstances are } \\
\text { exempted from the requirements of this Code: } \bullet \text { Where the animal is part of a competitive display } \\
\text { of household pets. - Where the animal is part of a competitive display of domestic farm animals. } \\
\text { - Where the animal is sold or offered for sale in the course of carrying on the business of animal } \\
\text { research, or in the course of carrying out animal research, without contravening the Animal } \\
\text { Research Act } 1985 \text {. Where the animal is at an agricultural show or show parade conducted by } \\
\text { the Royal Agricultural Society or a society that is a member of the Agricultural Societies Council. } \\
\text { - - Where the animal is a lawful captive and is at a meeting of an association dedicated to the }\end{array}$ \\
\hline
\end{tabular}


keeping of that type of animal. - Where the animal is kept by a dog or cat breeder, or by an animal shelter or council pound, activities for which the standards are set by other Codes in this series.

Animal Research Act 1985 (NSW)

Crimes Act 1900(NSW)
Animal Research Regulation 2010 (NSW) Division 4 Exemptions from the Act:

s15: Certain schools may carry on animal research without accreditation

(1) A non-government school is exempt from the operation of section 46 (1) of the Act with respect to the carrying on of the business of animal research:

(a) if the school belongs to, or is associated with, a relevant Association that is accredited under the Act, and

(b) so long as any animal research carried out at the school is carried out with the authority of an ethics committee for the relevant Association and in accordance with the Code of Practice.

(2) In this clause, relevant Association means any of the following:

(a) the Association of Independent Schools of New South Wales Limited,

(b) the Catholic Education Commission NSW.

16 School students may carry out animal research without authorities

A student at a school is exempt from the operation of section 47(1) of the Act with respect to the carrying out of animal research, so long as the animal research is carried out under the supervision, and in accordance with the directions, of the holder of an animal research authority. s 530 Serious Animal Cruelty:

(2) A person is not criminally responsible for an offence against this section if:

(a) the conduct occurred in accordance with an authority conferred by or under the Animal Research Act 1985

or any other Act or law, or

(b) the conduct occurred in the course of or for the purposes of routine agricultural or animal husbandry activities, recognised religious practices, the extermination of pest animals or veterinary practice.

\section{Appendix 2D: Definition of 'Animal' under which 'Rabbit' falls in Vic Statutes}

\begin{tabular}{|c|c|}
\hline Statute & Definition of Animal \\
\hline \multirow[t]{2}{*}{$\begin{array}{l}\text { Prevention of Cruelty to Animals } \\
\text { Act } 1986 \text { (VIC) }\end{array}$} & $\begin{array}{l}\text { s } 4 \text { (3): } \\
\text { (a) a live member of a vertebrate species including any- } \\
\text { (i) fish or amphibian; or } \\
\text { (ii) reptile, bird or mammal, other than any human being or any reptile, bird } \\
\text { or other mammal that is below the normal mid-point of gestation or incubation } \\
\text { for the particular class of reptile, bird or mammal; or }\end{array}$ \\
\hline & $\begin{array}{l}\text { specified animal means- } \\
\text { (a) guinea pig; and } \\
\text { (b) rat, mouse or rabbit, other than a rat, mouse or rabbit bred in its native } \\
\text { habitat; and } \\
\text { (c) non-human primate. }\end{array}$ \\
\hline Domestic Animal Act 1994 (VIC) & $\begin{array}{l}\text { prescribed class of animal means any of the following- (a) dogs; (b) cats; (c) } \\
\text { horses; (d) a class of animal prescribed by the regulations**; } \\
* * \text { Domestic Animals Regulations } 2015: \text { "prescribed animal means an animal } \\
\text { of a prescribed class of animal" [part } 1, \mathrm{~s} 5]\end{array}$ \\
\hline $\begin{array}{l}\text { Catchment and Land Protection } \\
\text { Act } 1994 \text { (VIC) }\end{array}$ & s64 prohibited pest, s65 controlled pest, s66 regulated pest \\
\hline Meat Industry Act 1993 (VIC) & $\begin{array}{l}\text { s3: "consumable animal" means- (a) poultry; or (b) game; or (c) an animal } \\
\text { from any of the following families, if not living in a wild state- (i) cattle; or } \\
\text { (ii) sheep; or (iii) goat; or (iv) pig; or (v) horse; or (vi) donkey; or (vii) ostrich; } \\
\text { or (viii) deer; or (d) an animal prescribed to be a consumable animal; } \\
\text { game means- (a) an animal from any of the following families, if living in a } \\
\text { wild state- (i) rabbit; }\end{array}$ \\
\hline $\begin{array}{l}\text { Meat Industry Regulations } 2015 \\
\text { (VIC) }\end{array}$ & $\begin{array}{l}\text { s6: Prescribed consumable animals For the purposes of paragraph (d) of } \\
\text { the definition of consumable animal in section } 3(1) \text { of the Act, the following } \\
\text { animals are prescribed to be consumable animals- (a) emu; (b) camel; (c) } \\
\text { alpaca; (d) llama; (e) buffalo; (f) bison; (g) rabbit that is not living in a wild } \\
\text { state }\end{array}$ \\
\hline
\end{tabular}




\section{Appendix 2E: Rabbit Uses and Associated Welfare Regulatory Instruments (Vic)}

\begin{tabular}{|c|c|c|}
\hline Rabbit Use & Regulatory Instrument & Voluntary Codes \\
\hline Rabbits Raised for food & $\begin{array}{l}\text { - Prevention of Cruelty to Animals Act } \\
1986 \text { (VIC) } \\
\text { - Prevention of Cruelty to Animals } \\
\text { Regulations } 2008 \text { (VIC) } \\
\text { - Meat Industry Act } 1993 \text { (VIC) } \\
\text { - Meat Industry Regulations } 2015 \\
\text { (VIC) } \\
\text { - Australian Standard for the hygienic } \\
\text { production and transportation of meat } \\
\text { and meat products for human } \\
\text { consumption }\end{array}$ & $\begin{array}{l}\text { - Model code of Practice for the welfare of } \\
\text { animals: Intensive Husbandry of rabbits }\end{array}$ \\
\hline Rabbits raised for fur/pelt & $\begin{array}{l}\text { - Prevention of Cruelty to Animals Act } \\
1986 \text { (VIC) } \\
\text { - Prevention of Cruelty to Animals } \\
\text { Regulations } 2008 \text { (VIC) }\end{array}$ & $\begin{array}{l}\text { - Model code of Practice for the welfare of } \\
\text { animals: Intensive Husbandry of rabbits }\end{array}$ \\
\hline Rabbits used for research & $\begin{array}{l}\text { - Prevention of Cruelty to Animals Act } \\
1986 \text { (VIC) } \\
\text { - Prevention of Cruelty to Animals } \\
\text { Regulations } 2008 \text { (VIC) } \\
\text { - Australian code for the care and use } \\
\text { of animals for scientific purposes 8th } \\
\text { edition (2013) } \\
\text { - Code of Practice for the Housing and } \\
\text { Care of Laboratory Mice, Rats, } \\
\text { Guinea Pigs and Rabbits } \\
\text { - Code of practice for the use of } \\
\text { animals from municipal pounds in } \\
\text { scientific procedures }\end{array}$ & \\
\hline Rabbits as pets & $\begin{array}{l}\text { - Prevention of Cruelty to Animals Act } \\
1986 \text { (VIC) } \\
\text { - Prevention of Cruelty to Animals } \\
\text { Regulations } 2008 \text { (VIC) } \\
\text { - Domestic Animal Act } 1994 \text { (VIC) } \\
\text { - Code of Practice for the Operation of } \\
\text { Pet Shops }\end{array}$ & \\
\hline
\end{tabular}

\section{Appendix 2F: Rabbit Exemptions from Welfare Regulatory Instruments (Vic)}

\begin{tabular}{|l|l|}
\hline $\begin{array}{l}\text { Regulatory } \\
\text { Instrument }\end{array}$ & Exemptions \\
\hline $\begin{array}{l}\text { Prevention of } \\
\text { Cruelty to Animals } 1986 \text { (VIC) }\end{array}$ & $\begin{array}{l}\text { s 6: } \\
\text { (1)This Act does not apply to- } \\
\text { (a) the slaughter of animals in accordance with the Meat Industry Act 1993 (Vic) or any } \\
\text { Commonwealth Act } \\
\text { (b) except to the extent that it is necessary to rely upon a Code of Practice as a defence to an } \\
\text { offence under this Act, the keeping, treatment, handling, transportation, sale, killing, hunting, } \\
\text { shooting, catching, trapping, netting, marking, care, use, husbandry or management of any } \\
\text { animal or class of animals (other than a farm animal or class of farm animals) which is carried } \\
\text { out in accordance with a Code of Practice; or } \\
\text { (c) any act or practice with respect to the farming, transport, sale or killing of any farm animal } \\
\text { which is carried out in accordance with a Code of Practice; or } \\
\text { (d) anything done in accordance with the Catchment and Land Protection Act 1994 (Vic); or } \\
\text { (e) the treatment of any animal for the purpose of promoting its health or welfare by or in } \\
\text { accordance with the instructions of a veterinary practitioner; or }\end{array}$ \\
\hline $\begin{array}{l}\text { Prevention of } \\
\text { Cruelty to Animals } \\
\text { Regulations 2008 } \\
\text { (VIC) }\end{array}$ & $\begin{array}{l}\text { Regulation 32(7) Sub-regulations (2) to (6)** do not apply in circumstances where the use has } \\
\text { been otherwise approved by an Animal Ethics Committee for research approved under licence } \\
\text { in accordance with Part 3 of the Act. }\end{array}$ \\
\hline
\end{tabular}




\begin{tabular}{|c|c|}
\hline $\begin{array}{l}\text { Animals in } \\
\text { Research }\end{array}$ & \\
\hline $\begin{array}{l}\text { Domestic Animal } \\
\text { Act } 1994 \text { (VIC) }\end{array}$ & Only specifies dogs and cats \\
\hline $\begin{array}{l}\text { Meat Industry Act } \\
1993 \text { (Vic) }\end{array}$ & $\begin{array}{l}\text { s 5: } \\
\text { (b) the slaughter of an animal on a farm if - (i) it is slaughtered for consumption on that farm; } \\
\text { and (ii) it is not slaughtered for sale; and (iii) it is not slaughtered for use in the preparation of } \\
\text { food for sale; and (iv) it is not removed from that farm; and }\end{array}$ \\
\hline
\end{tabular}

Appendix 2G: Definition of 'Animal' under which 'Rabbit' falls in WA Statutes

\begin{tabular}{|c|c|}
\hline Statute & Definition of Animal \\
\hline Animal Welfare Act 2002 (WA) & $\begin{array}{l}\text { s 5(1): animal means - (a) a live vertebrate; or (b) a live invertebrate of a } \\
\text { prescribed kind, other than a human or a fish (as defined in the Fish } \\
\text { Resources Management Act 1994); }\end{array}$ \\
\hline $\begin{array}{l}\text { Animal Resources Authority Act } 1981 \\
\text { (WA) }\end{array}$ & $\begin{array}{l}\text { s3: laboratory animal means an animal used for teaching, research, or } \\
\text { diagnostic purposes or for any purpose incidental thereto; }\end{array}$ \\
\hline Food Act 2008 (WA) & $\begin{array}{l}\text { s8: "animal includes an amphibian, bird, crustacean, fish, mollusc and } \\
\text { reptile;" }\end{array}$ \\
\hline Food Regulations 2009 (WA) & Regulation 17: "animal does not include a fish, crustacean or mollusc" \\
\hline $\begin{array}{l}\text { Biosecurity and Agriculture } \\
\text { Management Act } 2007 \text { (WA) }\end{array}$ & $\begin{array}{l}\text { s6: animal means a living or previously living thing except a human being, } \\
\text { plant or micro-organism, and includes - (a) the ovum, semen or any other } \\
\text { genetic material of an animal; and (b) an animal when in the embryonic or } \\
\text { larval stage or any other immature stage; } \\
\text { S6: declared pest means - (a) a prohibited organism; or (b) an organism } \\
\text { for which a declaration under section } 22(2) \text { is in force; Declared Pest } \\
\text { Account }\end{array}$ \\
\hline $\begin{array}{l}\text { Biosecurity and Agriculture } \\
\text { Management (Declared Pests) } \\
\text { Declaration } 2013 \text { (WA) }\end{array}$ & $\begin{array}{l}\text { Oryctolagus cuniculus (domestic) } \\
\text { Family: Leporidae } \\
\text { Declared Pest - s22(2) (C3 Exempt) } \\
\text { Common names: Domestic rabbit, Domestic / Fancy breeds or } \\
\text { commercial breed, not wild-type rabbit with brown colouring. } \\
\text { Oryctolagus cuniculus (feral) } \\
\text { Family: Leporidae } \\
\text { Declared Pest - s22(2) (C3 Prohibited) } \\
\text { Common names: Wild rabbit with wild-type brown colouring, not } \\
\text { domestic or fancy breeds or commercial breed., European rabbit. }\end{array}$ \\
\hline
\end{tabular}

\section{Appendix 2H: Rabbit Uses and Associated Welfare Regulatory Instruments (WA)}

\begin{tabular}{|c|c|c|}
\hline Rabbit Use & Regulatory Instrument & Voluntary Codes \\
\hline Rabbits Raised for food & $\begin{array}{l}\text { - Animal Welfare Act } 2002 \text { (WA) } \\
\text { - Animal Welfare (General) Regulation } 2003 \text { (WA) } \\
\text { - Food Act } 2008 \text { (WA) } \\
\text { - Food Regulations } 2009 \text { (WA) } \\
\text { - Australian standard for hygienic production of } \\
\text { rabbit meat for human consumption } \\
\text { - Australian Standard for the hygienic production } \\
\text { and transportation of meat and meat products for } \\
\text { human consumption }\end{array}$ & $\begin{array}{l}\text { - Model code of Practice } \\
\text { for the welfare of } \\
\text { animals: Intensive } \\
\text { Husbandry of rabbits }\end{array}$ \\
\hline Rabbits raised for fur/pelt & $\begin{array}{l}\text { - Animal Welfare Act } 2002 \text { (WA) } \\
\text { - Animal Welfare (General) Regulation } 2003 \text { (WA) }\end{array}$ & $\begin{array}{l}\text { - Model code of Practice } \\
\text { for the welfare of } \\
\text { animals: Intensive } \\
\text { Husbandry of rabbits }\end{array}$ \\
\hline Rabbits used for research & $\begin{array}{l}\text { - Animal Welfare Act } 2002 \text { (WA) } \\
\text { - Animal Welfare (Scientific Purposes) Regulation } \\
2003 \text { (WA) }\end{array}$ & \\
\hline
\end{tabular}


- Australian code for the care and use of animals for scientific purposes 8th edition (2013)

Rabbits as pets

- Animal Welfare Act 2002 (WA)

- Animal Welfare (General) Regulation 2003 (WA)

\section{Appendix 2I Rabbit Exemptions from Welfare Regulatory Instruments (WA)}

\begin{tabular}{|c|c|}
\hline $\begin{array}{l}\text { Regulatory } \\
\text { Instrument }\end{array}$ & Exemptions \\
\hline $\begin{array}{l}\text { Animal } \\
\text { Welfare Act } \\
2002 \text { (WA) }\end{array}$ & $\begin{array}{l}\text { s23: Defence - normal animal husbandry } \\
\text { It is a defence to a charge under section } 19(1)^{* *} \text { for a person to prove that the act alleged to constitute } \\
\text { the offence was done - (a) in accordance with a generally accepted animal husbandry practice, other } \\
\text { than a prescribed practice, that is used in - (i) farming or grazing activities; (ii) the management of } \\
\text { zoos, wildlife parks or similar establishments; (iii) the management of animal breeding establishments; } \\
\text { or (iv) the training of animals; and (b) in a humane manner. } \\
* * \text { cruelty to animals } \\
\text { s25: Defence - code of practice } \\
\text { It is a defence to a charge under section } 19(1) \text { for a person to prove that the person was acting in } \\
\text { accordance with a relevant code of practice. } \\
\text { s30: Defence - prescribed surgical or similar operations, practices and activities It is a defence to a } \\
\text { charge under section } 19(1) \text { committed in circumstances described in section } 19(3) \text { (g) for a person to } \\
\text { prove that the person was a prescribed person, or was in a prescribed class of persons, and carried out } \\
\text { the operation, practice or activity in a prescribed manner. } \\
\text { s32: Shooting, hunting or fighting captive animals } \\
\text { (1) A person must not engage in a prohibited activity. } \\
\text { (4) It is a defence to a charge under subsection (1) where the activity the subject of the charge is the } \\
\text { releasing of an animal for the purposes of it being hunted by another animal for a person to prove that } \\
\text { predato the animal was released as food for a predatory animal kept in captivity; (b) the diet of captive } \\
\text { predatory animal will not ordinarily eat dead meat. } \\
\text { Part } 5 \\
\text { s84: Breach of code of practice not sufficient to prove cruelty } \\
\text { s85: Death of animal not sufficient to prove cruelty }\end{array}$ \\
\hline $\begin{array}{l}\text { Animal } \\
\text { Welfare } \\
\text { (General) } \\
\text { Regulations } \\
2003 \text { (WA) }\end{array}$ & $\begin{array}{l}\text { Regulation 6: Codes of practice adopted as defences (ss. } 25 \text { and } 94(2)(\mathrm{d}))^{* *} \\
\text { The codes of practice relating to the use, care, welfare, safety or health of animals set out in Schedule } \\
1 \text { are adopted, as they are amended from time to time, under section } 94(2)(\mathrm{d}) \text { of the Act, and each is a } \\
\text { "relevant code of practice" that can be used as a defence under section } 25 \text { of the Act. } \\
* * \text { S94(2)(d): (2) Without limiting subsection (1) regulations made under this section may - (d) adopt } \\
\text { codes of practice relating to the use, care, welfare, safety or health of animals either - (i) as modified } \\
\text { by the regulations; (ii) as they exist at a particular date; or (iii) as they are amended from time to time; } \\
\text { Regulation } 7 \text { 7: Use of devices - electric shock (s. } 29) \\
\text { Device Purpose Type of animal Manner of use Electric stunning device Electrical stunning of animals } \\
\text { in an abattoir Cattle, sheep, goats or pigs [rabbits not part of the definition to use stunning devices] } \\
\text { For the purposes of section } 29 \text { of the Act, it is a defence to a charge under section } 19(1) * * * * \text { of the } \\
\text { Act, committed in circumstances described in section } 19(2)(\mathrm{b}) \text { of the Act, if the device used is one set } \\
\text { out in the Table to this regulation, and the device is used on an animal for the purpose, and in } \\
\text { accordance with the conditions, set out next to that device in that Table. } \\
* * * * 19(1) \text { : cruelty to an animal }\end{array}$ \\
\hline
\end{tabular}

Appendix 3A: Model Code of Practice for the Welfare of Animals: Intensive Husbandry of Rabbits (NSW, Vic, WA)

\begin{tabular}{|c|c|c|c|c|}
\hline STATE/TERRITORY & COMMONWEALTH & NSW & WA & VICTORIA \\
\hline $\begin{array}{l}\text { ADOPTION/ USE IN } \\
\text { LAW }\end{array}$ & $\begin{array}{l}\text { Guide (see individual } \\
\text { states and territories) }\end{array}$ & Guide/evidence & Guide/defence & Guide/defence \\
\hline $\begin{array}{l}\text { CODE OF } \\
\text { PRACTICE }\end{array}$ & $\begin{array}{l}\text { The Model Code of } \\
\text { Practice for the Welfare } \\
\text { of Animals: Intensive } \\
\text { Husbandry of Rabbits } \\
\text { (MCOPIHR) }\end{array}$ & $\begin{array}{l}\text { Model Code of } \\
\text { Practice for the } \\
\text { Welfare of } \\
\text { Animals: } \\
\text { Intensive } \\
\text { Husbandry of }\end{array}$ & $\begin{array}{l}\text { Code of } \\
\text { practice for } \\
\text { keeping of } \\
\text { Rabbits in WA }\end{array}$ & $\begin{array}{l}\text { Code of practice for the } \\
\text { intensive husbandry of } \\
\text { rabbits Vic }\end{array}$ \\
\hline
\end{tabular}




\begin{tabular}{|c|c|c|c|c|}
\hline & & Rabbits & & \\
\hline $\begin{array}{l}\text { PUBLICATION } \\
\text { DATE }\end{array}$ & 1991 & $\begin{array}{l}1991 \text { (Based on } \\
\text { MCOPIHR) }\end{array}$ & $\begin{array}{l}1991 \text { (Based } \\
\text { on } \\
\text { MCOPIHR) }\end{array}$ & $\begin{array}{lr}1997 \quad \text { (Based } & \text { on } \\
\text { MCOPIHR } & \text { with } \\
\text { Additions) } & \\
\end{array}$ \\
\hline OBJECTIVE & $\begin{array}{l}\text { Guide for the intensive } \\
\text { husbandry of domestic- } \\
\text { type rabbits for } \\
\text { commercial production. } \\
\text { Recognises that the basic } \\
\text { requirement for the } \\
\text { welfare of rabbits is a } \\
\text { husbandry system } \\
\text { appropriate to their } \\
\text { physiological and } \\
\text { behavioural needs. }\end{array}$ & $\begin{array}{l}\text { same } \\
\text { MCOPIHR }\end{array}$ & $\begin{array}{l}\text { same as } \\
\text { MCOPIHR }\end{array}$ & same as MCOPIHR \\
\hline BASIC NEEDS & $\begin{array}{l}\text { Accommodation } \\
\text { providing protection and } \\
\text { does not harm or cause } \\
\text { discomfort } \\
\text { Freedom of movement to } \\
\text { stand, stretch, turn } \\
\text { around and lie down } \\
\text { Readily accessible food } \\
\text { and water } \\
\text { Rapid recognition and } \\
\text { treatment of injury and } \\
\text { disease }\end{array}$ & $\begin{array}{ll}\text { same } & \text { as } \\
\text { MCOPIHR }\end{array}$ & $\begin{array}{l}\text { same as } \\
\text { MCOPIHR }\end{array}$ & 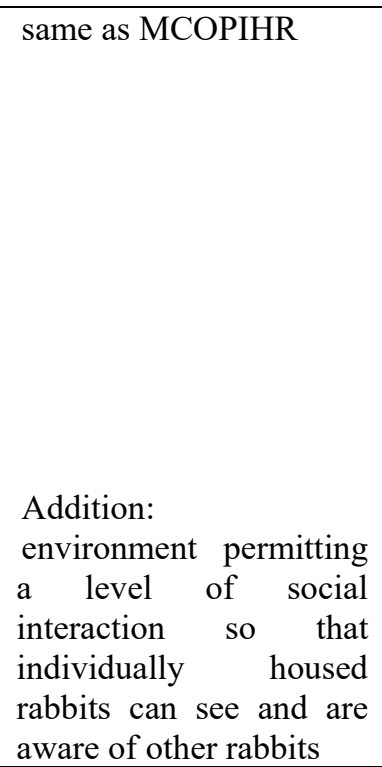 \\
\hline ENVIRONMENT & $\begin{array}{l}\text { Temperature optimal } \\
\text { range (10C-25C) } \\
\text { Ventilation to prevent } \\
\text { build up of moisture, } \\
\text { ammonia and heat / } \\
\text { Internal surfaces smooth } \\
\text { to avoid accumulation of } \\
\text { dust and fluff }\end{array}$ & $\begin{array}{ll}\text { same } & \text { as } \\
\text { MCOPIHR }\end{array}$ & $\begin{array}{l}\text { same as } \\
\text { MCOPIHR }\end{array}$ & $\begin{array}{l}\text { Same as MCOPIHR } \\
\text { Addition: In addition to } \\
\text { adequate ventilation, } \\
\text { means of urine disposal } \\
\text { from housing areas must } \\
\text { be effective to reduce } \\
\text { accumulation } \\
\text { ammonia. } \\
\text { ammonia levels reach the } \\
\text { point of being detectable } \\
\text { by human sense of smell } \\
\text { remedial action needs to } \\
\text { be taken to reduce the } \\
\text { level. Faeces should be } \\
\text { removed from both the } \\
\text { immediate environment } \\
\text { of the rabbits and from } \\
\text { the confines of the shed } \\
\text { on a regular basis. }\end{array}$ \\
\hline
\end{tabular}




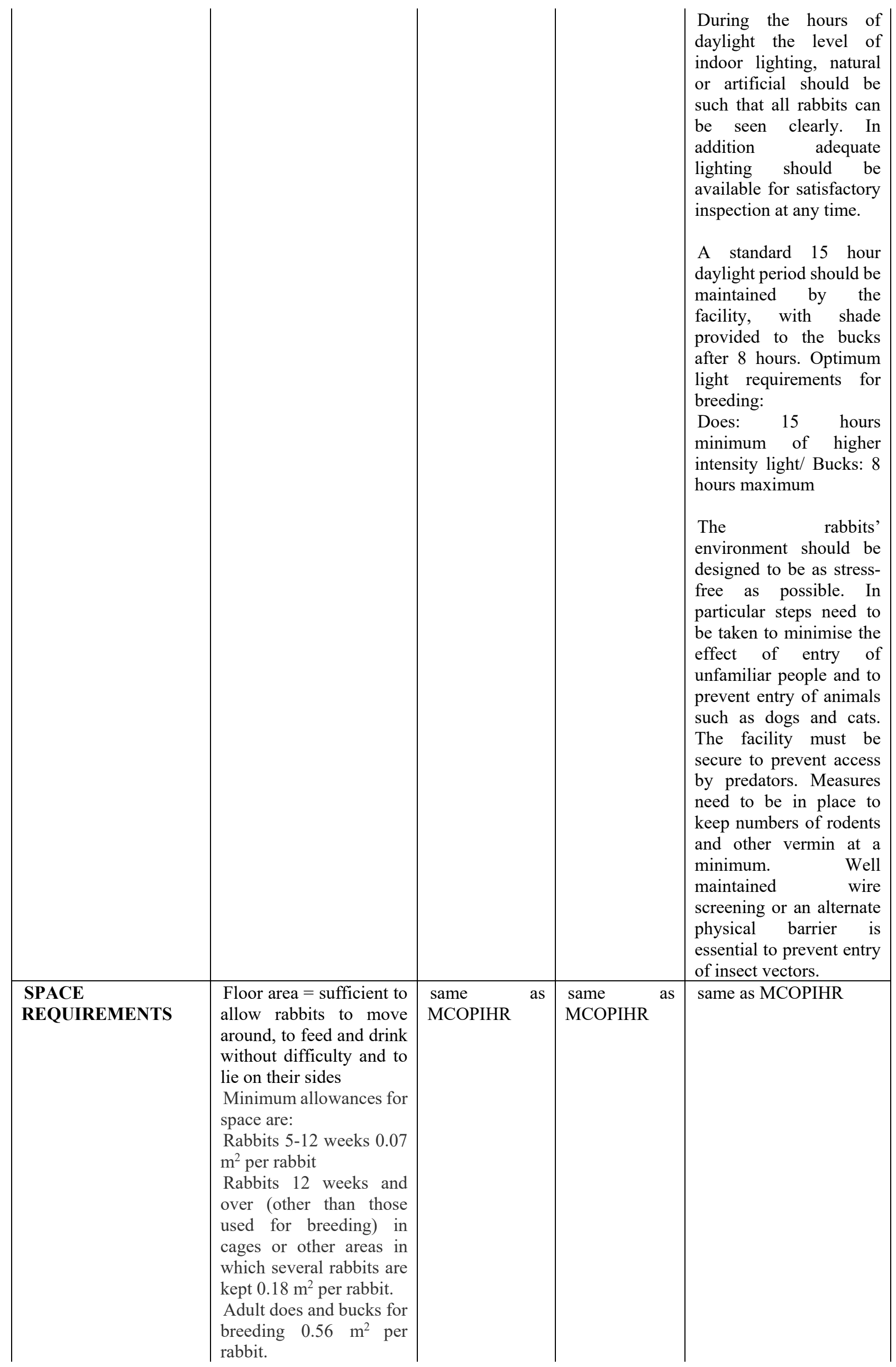




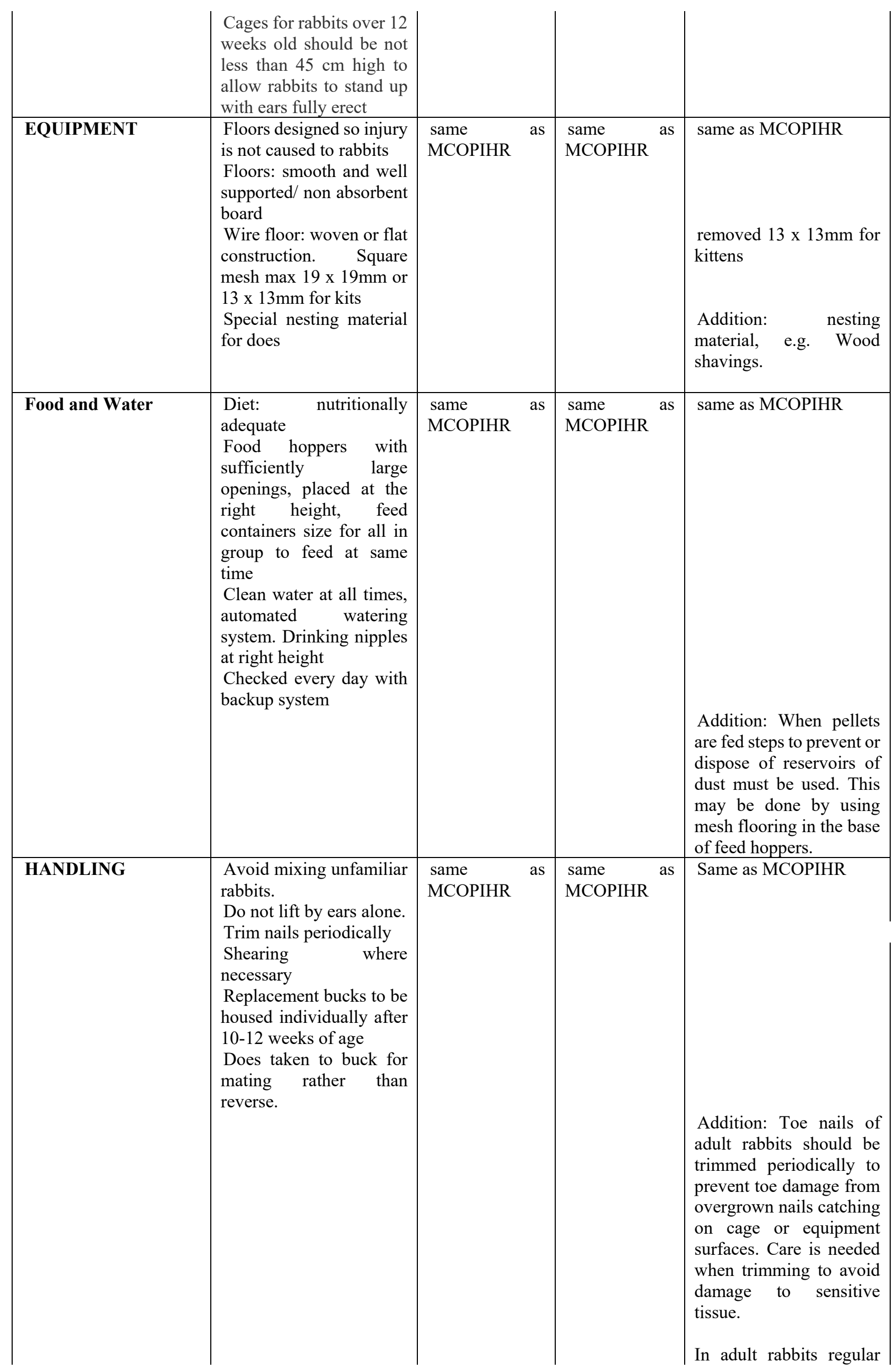




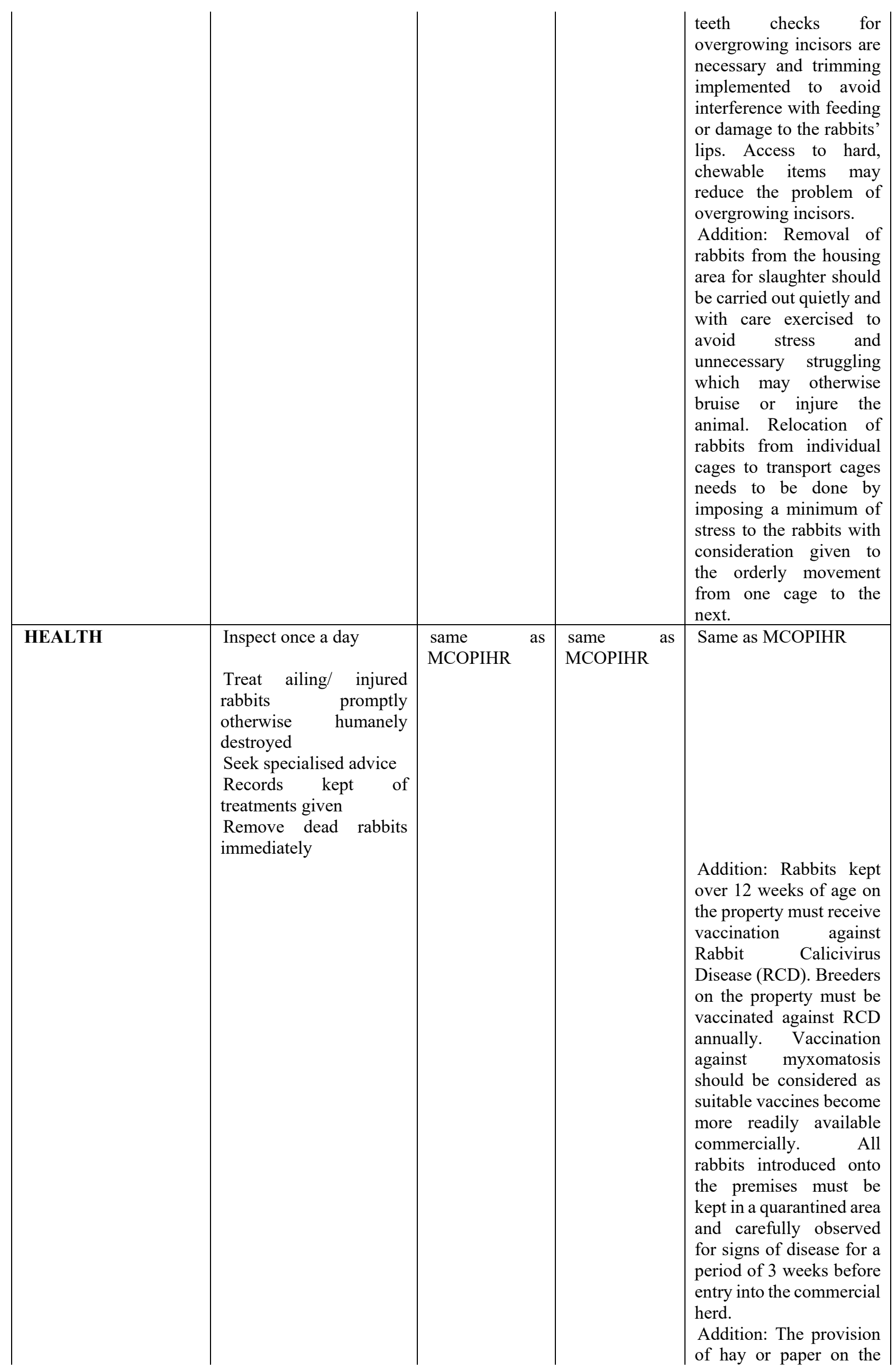




\begin{tabular}{|c|c|c|c|c|}
\hline & & & & $\begin{array}{l}\text { floor may assist in the } \\
\text { treatment of foot injuries. } \\
\text { Addition: Any use of } \\
\text { antibiotics and other } \\
\text { drugs must be under } \\
\text { veterinary supervision } \\
\text { with all due care taken to } \\
\text { avoid chemical residues } \\
\text { in the carcass meat. Dead } \\
\text { rabbits must be removed } \\
\text { and disposed of promptly } \\
\text { and hygienically }\end{array}$ \\
\hline PROTECTION & $\begin{array}{l}\text { Protect from predators or } \\
\text { other animals } \\
\text { Keep free from feral } \\
\text { rabbits and rodents } \\
\text { Insect proofing } \\
\text { (protection from } \\
\text { myxomatosis) } \\
\text { Fire-fighting equipment } \\
\text { available }\end{array}$ & $\begin{array}{ll}\text { same } & \text { as } \\
\text { MCOPIHR }\end{array}$ & $\begin{array}{l}\text { same as } \\
\text { MCOPIHR }\end{array}$ & Same as MCOPIHR \\
\hline TRANSPORT & $\begin{array}{l}\text { Ventilated containers/ } \\
\text { large enough to allow } \\
\text { animals to turn around } \\
\text { and lie down/ small } \\
\text { enough to prevent } \\
\text { bruising } \\
\text { Protect rabbits from } \\
\text { wind and rain and } \\
\text { excessive temps } \\
\text { Do not hold in transit for } \\
\text { more than } 24 \text { hours } \\
\text { without food and water. }\end{array}$ & & & Same as MCOPIHR \\
\hline EUTHANASIA & $\begin{array}{l}\text { Destroyed humanely. } \\
\text { Cervical dislocation is an } \\
\text { acceptable method. }\end{array}$ & $\begin{array}{ll}\text { same } & \text { as } \\
\text { MCOPIHR }\end{array}$ & $\begin{array}{l}\text { same as } \\
\text { MCOPIHR }\end{array}$ & $\begin{array}{l}\text { Same as MCOPIHR } \\
\text { Addition: Humane } \\
\text { slaughter for human } \\
\text { consumption } \\
\text { The method of slaughter } \\
\text { of rabbits in licensed } \\
\text { abattoirs must be humane } \\
\text { and must adhere to the } \\
\text { standard outlined in the } \\
\text { Australian Standard for } \\
\text { Hygienic Production of } \\
\text { Rabbit Meat for Human } \\
\text { Consumption endorsed } \\
\text { by the Agriculture and } \\
\text { Resource Management } \\
\text { Council of Australia and } \\
\text { New Zealand } \\
\text { (ARMCANZ). This } \\
\text { stipulation particularly } \\
\text { applies to the } \\
\text { requirement for rabbits to } \\
\text { be humanely transported, } \\
\text { restrained and handled } \\
\text { prior to slaughter and to } \\
\text { be electrically stunned or } \\
\text { made unconscious and } \\
\text { insensible to pain by }\end{array}$ \\
\hline
\end{tabular}




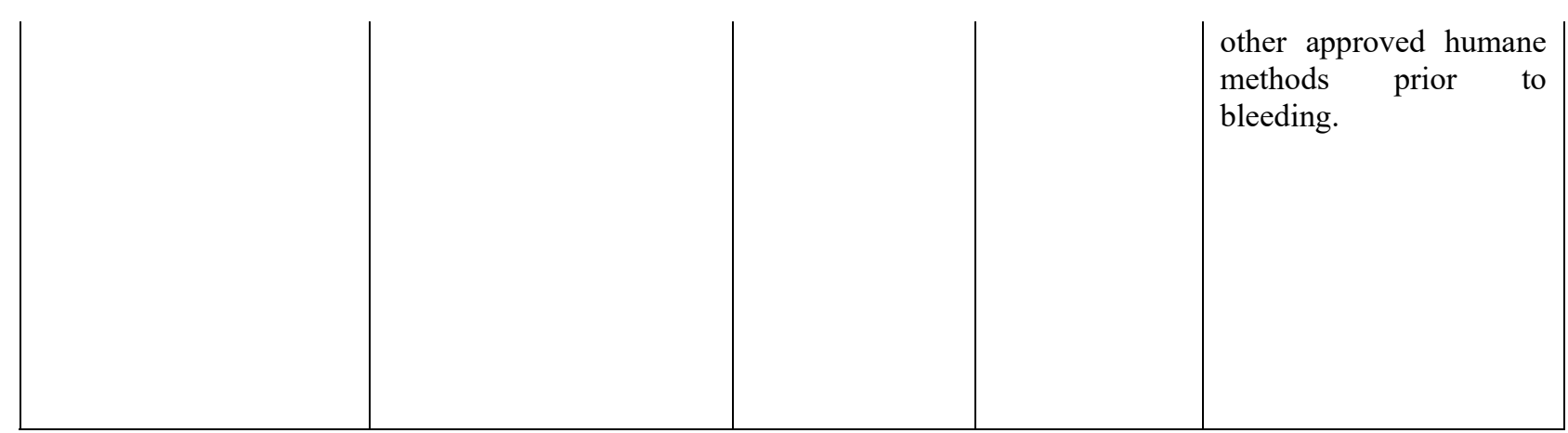

\section{Appendix 3B: Summary of the EFSA's report The Impact of the current housing and husbandry systems on the health and welfare of farmed domestic rabbits}

- There are no genetic differences that cause farmed rabbits to have different needs from laboratory rabbits or pet rabbits, and there will be few differences from wild rabbits; $;{ }^{915}$

- Rabbits have been domesticated relatively recently, compared with other domestic animals. Domestic rabbits show behaviours typical of wild rabbits, such as mating, maternal behaviour, nest building, and the social system; ${ }^{916}$

- Both adult bucks and does exhibit independent rank orders and once set up, the rank order stays stable; 917

- Rabbits reproduce and express high fitness levels (reproductive success) in nature and controlled environments, however this does not mean that their welfare has not been affected; ${ }^{918}$

- Under commercial conditions the incidence of sore hocks (footpad lesions) from wire flooring can be quite high, as it is the $3^{\text {rd }}$ most common reason for culling, ${ }^{919}$

- Poor animal handling can cause serious injuries; ${ }^{920}$

- Keeping animals in overly confined conditions causes suffering; ${ }^{921}$

- Based on behavioural studies, lower space allowances carry the risk of poor welfare. Because of the reduced functional space, the risk of overcrowding and inability to carry out certain behaviours is larger in small cages than in large cages even at the same space allowance; 922

- Breeding males are kept for about one year and should be given adequate space to lie out and to move, e.g. hop around; ${ }^{923}$

- As rabbits get heavier and bigger, they are less able to carry out certain behaviours due to obvious space restriction; ${ }^{924}$

- As rabbits cool by lying out, more space is needed to permit that behaviour when the ventilation system does not maintain suitable ambient conditions; $;{ }^{925}$

- It may be important for growing rabbits to be able to sit and stand with their ears erect, and occasionally to rear up, as these are evolutionary behaviours to increase the rabbits' field of vision on arousal and to thermoregulate; ${ }^{926}$

- Rabbits should be able to rest, withdraw and hide from sources of potential danger; $;{ }^{927}$

- Rabbits should be able to carry out normal behaviour and physiological activities, including caecotrophy according to the diurnal rhythms, ${ }^{928}$

- Feed-restricted animals should have access to objects they can gnaw; 929

915 Scientific Panel on Animal Health and Welfare, 'The Impact of the current housing and husbandry systems on the health and welfare of farmed domestic rabbits' (2005) 267 The EFSA Journal, 12.

916 Ibid.

917 Ibid.

918 Ibid.

919 Ibid 9.

920 Ibid 8.

921 Ibid 9.

922 Ibid 11

923 Ibid.

924 Ibid 12

925 Ibid.

926 Ibid 13

927 Ibid 15

928 Ibid.

929 Ibid. 
- During breeding, the mother should be allowed to build a nest, and to be apart from the litter and other stimuli, either by her own activity or by management measures, ${ }^{930}$ and

- When group housing rabbits, the environment should be subdivided by partitions in such a way that each animal is able to initiate or to avoid social contact. ${ }^{931}$

\section{Appendix 3C: Summary of the Ethological Needs of Rabbits as Identified by the Brief of Requirements (BoR)}

- The following are the needs of the rabbits as identified by the BoR: Physical comfort (Rest, Locomotion, Body care); Reproduction (Sexual behaviour, Nest building, Maternal behaviour); Physiological comfort (Excretion, Thermoregulation, Respiration); Nutrition (Food and Water); Other behaviours (Social interaction, Play); Health (No illness, No injury, Safety, No danger, Minimal aggression): ${ }^{932}$

- Physical comfort (rest): Rabbits attempt to divide their living space into separate areas for feeding, resting and excretion. Rabbits tend to rest where other rabbits are already resting. For about half of the time when they rest, rabbits are in body contact with another rabbit. Depending on the degree of relaxation, rabbits rest in a crouched position (lying alert), or with their hind legs stretched out laterally or behind the body or lying on their side with all legs extended; ${ }^{933}$

- Physical comfort (locomotion): Rabbits should be able to perform locomotive behaviour, including hops, jumps, frisky hops, running and turning. It has been shown that if they are unable to perform these behaviours they suffer injury to their locomotor system; ${ }^{934}$

- Physical comfort (body care): Rabbits show many kinds of comfort behaviours such as scratching, stretching, yawning, sneezing and grooming. They prefer to groom and mutual-groom during resting. Presence of other rabbits and enough space to perform the behaviour is important; ${ }^{935}$

- Reproduction (Sexual behaviour): In the wild, rabbits are mated directly after post-partum during the mating season. However, during wintertime they are inactive and restore body reserves; ${ }^{936}$

- Reproduction (Nest building): Nests are constructed by the doe so that the kits stay in the nest and the doe can fill it with nesting material and hair so that it offers the needed insulation for the kits. A doe can manipulate to build her own nest by digging and scraping into it. Digging is a natural behaviour for rabbit does, and when the substrate does not change when doing so, the doe's emotions are frustrated, and the digging is considered abnormal; ${ }^{937}$

- Reproduction (Maternal behaviour): Under natural circumstances does suckle their kits once a day for a few minutes, usually at dusk and/or dawn. During the rest of the period they close the nest and leave it. This is an evolutionary adaptive behaviour and serves as predator avoidance, but also to keep the climatic conditions for the kits optimal. Furthermore, the doe and kits should not be disturbed during suckling. Startling of the doe might lead to abrupt suckling termination or even trampling of kits. Weaning of the kits should occur at an appropriate age. In the wild, when does are mated post-partum, kits are usually weaned at age 23 to 25 days; ${ }^{938}$

- Physiological comfort (Excretion): There should be an excretion area distinct from a feeding and resting area; ${ }^{939}$

- Physiological comfort (Thermoregulation): Rabbits are extremely susceptible to high temperatures and draught. Rabbit have several thermoregulation strategies, they lie out straight to cool down and they huddle together to warm themselves, ${ }^{940}$

- Physiological comfort (Respiration): the air needs to be of a good quality (e.g. avoiding too high levels of $\mathrm{NH}_{3}, \mathrm{CO}_{2}, \mathrm{NO}$ ), which requires adequate ventilation; ${ }^{941}$ 
- Nutrition (Food): Rabbits eat many times per day and should be able to eat whenever they feel the need. Food should be provided in a feeding area, which is distinct from a resting and excretion area. Rabbit diets should contain enough fibre for prevention of digestive problems; ${ }^{942}$

- Nutrition (Water): Rabbits should have ad libitum access to water, ${ }^{943}$

- Other Behaviours (Social contact): Rabbits are gregarious animals and need the presence of conspecifics. They have a high motivation for social contact. There are dominance hierarchies within the environment. Rabbits initiate or avoid social contact and/or physical contact; ${ }^{944}$

- Other Behaviours (Play): mostly in the form of gambolling, zigzagging and jumping. During gambolling speeds of $30 \mathrm{~km} /$ hour are reached, zigzagging and jumps up to 1 metre in the air take place, ${ }^{945}$

- Health (No illness): Illness is closely related to hygiene. Rabbits avoid being in contact with their faeces and/or urine; ${ }^{946}$

- Health (No injury): Slippery flooring can cause hip dysplasia and other musculoskeletal changes in growing rabbits. Rabbits are easily injured during handling by humans, ${ }^{947}$

- Safety (No danger): Due to the high predator pressure (from the air and the ground) rabbits are very alert animals and they interrupt activities regularly to check the environment, by sitting or rearing up on their hind legs, either standing free or against objects, with ears upright and turned towards the stimulus. Rabbits are easily startled and need to be able to withdraw and hide from sources of potential danger. They prefer places where they are visually covered from above. Handling by humans can cause a lot of stress for rabbits; ${ }^{948}$ and

- Health (minimal aggression): Aggression occurs in unstable groups, but serious fights are rare in stable groups. There is very little aggression in family groups, consisting of one buck, several does and their young. In the wild, female young usually stay with their group. Male young leave their group, because the adults will drive them out. Bucks seem to play an appeasing role and intervene in fights between does and young. When a group is stable, no new members should be introduced, because hierarchy fights can start again. The living space and flight distance is also relevant. When these are limited, low-ranking rabbits in particular cannot withdraw when attacked. Therefore, there should be enough space and possibilities for rabbits to retreat from sight of each other. ${ }^{949}$ 